






\title{
American Diplomacy
}

\author{
under
}

Tyler and Polk 


\section{THE ALBERT SHAW LECTURES ON DIPLOMATIC HISTORY}

By the liberality of Albert Shaw, Ph. D., of New York City, the Johns Hopkins University has been enabled to provide an annual course of lectures on Diplomatic History. The courses are included in the regular work of the Department of History and are published under the direction of Professor John M. Vincent. 


\title{
THE ALBERT SHAW LECTURES ON
} DIPLOMATIC HISTORY, 1906

\section{American Diplomacy}

\author{
under
}

\section{Tyler and Polk}

By JESSE S. REEVES, Ph. D.

Assistant Professor of Political Science in Dartmouth College

BALTIMORE

The Johns Hopkins Press

1907 
Copyright, 1907

THE JOHNS HOPKINS PRESS

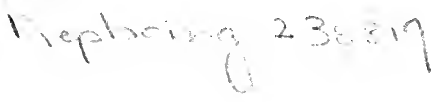

PRESS OF

KUHN \& POLLOCK, INC. BALTIMORE 


\section{CONTENTS}

Introduction

CHAPTER I

The Northeastern Boundary Controversy . . I

CHAPTER II

The Ashburton Treaty . . . . . . . 28

CHAPTER III

The Relations between Mexico and the United States concerning Texas, $1825-1840$. $\quad 58$

CHAPTER IV

The Relations between the United States and Mexico during the Secretaryship of Daniel Webster, I 84 I-I 843

CHAPTER V

The Negotiations for Texas under Upshur . . II4 CHAPTER VI

Calhoun and the attempted Annexation of Texas by Treaty . . . . . . . . . $\quad$ r 38

CHAPTER VII

The Annexation of Texas by Joint Resolution . $\quad$ I62 CHAPTER VIII

The Northwestern Boundary Controversy . . 190 
CONTENTS

CHAPTER IX

The Joint Occupation of Oregon

CHAPTER $\mathrm{X}$

The Oregon Treaty . . . . . . . . 243

CHAPTER XI

Polk's attempted Negotiation for California

CHAPTER XII

The Outbreak of the Mexican War . . . 288

CHAPTER XIII

The Treaty of Guadalupe Hidalgo, 1848

Index . . . . . . . . . . 33 I 
TO MY BROTHER, WILLIAM PE'TERS REEVES, PH. D. 



\section{INTRODUCTION}

The selection of the administrations of Tyler and Polk for treatment in a course of lectures upon American diplomatic history may seem somewhat arbitrary. Upon closer view, however, one sees that there is so much of continuity in the foreign relations of the United States during the terms of these two Presidents, both of whom have been called "accidental," that the years I84I to I849 may fairly be said to constitute an epoch quite distinct from the Jacksonian era, which preceded them, and the ante-bellum period proper, which followed. Yet it would be misleading to state that this epoch presented for solution problems altogether novel. The problems for the most part were as old as the nation. It was the method of their solution which was new. The questions which dominated the foreign policy of Tyler's and Polk's time were mainly those of boundary, dating from the first treaty of peace with England. The administrations of these two Presidents accomplished the settlement of three boundary questions: the northeastern and northwestern through negotiation, the southwestern by conquest.

These chapters in the history of American diplomacy deal principally with the questions of boundary. To have considered all of the diplomatic events during the years $184 \mathrm{I}$ to 1849 would have exceeded the limits of the present volume. The relations with China, Hawaii, New Granada, and Yucatan, to name 
only a few matters of importance, have been omitted in order to give space for sketches of the development of the three boundary problems. These preliminary outlines were necessary for the purpose of showing the diplomatic issues as they existed in I84I.

With the exceptions of Chapters XII and XIII the text is printed substantially as delivered in the form of lectures at the Johns Hopkins University. Chapter XIII appeared in the American Historical Review for January, I905; Chapter XII is largely taken up with the report of Mackenzie upon his visit to Santa Anna, which, I believe, has never before been printed. Perhaps it should be stated that the book was written wholly from materials accessible in the United States.

I take this opportunity of expressing my obligations to the authorities of the Lenox Library, New York, of the Chicago Historical Society, of the Library of Congress, and of the Department of State for courtesies had at their hands. To Mr. Worthington C. Ford, of the Library of Congress, and to Messrs. Andrew $\mathrm{H}$. Allen and Pendleton King, formerly chiefs respectively of the Bureau of Rolls and Library and of the Bureau of Indexes and Archives of the Department of State, I desire to express my thanks for their uniailing kindness and ready assistance. I am under many obligations to Professor Vincent, of the Johns Hopkins University, for valuable suggestions, and to Miss Mabel $\cdot M$. Reese, of Baltimore, Maryland, for her assistance in seeing the book through the press.

Richmond, Indiana, JESSE S. REEVES. August 12, 1907 . 


\section{CHAPTER I}

Time Northiastern Boundary Controversy

$$
\text { I 783-I } 84 \text { I }
$$

The treaty of peace with England was signed September 3, I783. The second article of the treaty set out the boundaries between the United States and the Pritish possessions on the north as follows: "From the northwest angle of Nova Scotia, viz. that angle which is formed by a line drawn due north from the source of the Saint Croix River to the Highlands; along the said Highlands which divide those rivers that empty themselves into the river St. Lawrence, from those which fall into the Atlantic Ocean, to the northwesternmost head of Connecticut River; thence down along the middle of that river, to the forty-fifth degree of north latitude; from thence, by a line due west on said latitude, until it strikes the river Iroquois or Cataraquy $;{ }^{1}$ thence along the middle of said river into Lake Ontario, through the middle of said lake until it strikes the communication by water between that lake and Lake Erie; thence along the middle of said communication into Lake Erie, through the mirdle of said lake until it arrives at the water commutication between that lake and Lake Huron; thence along the middle of said water communication into the Lake Huron; thence through the middle of said lake to the water communication between that lake and Lake

${ }^{1} i . e$, the St. Lawrence. 
Superior; thence through Lake Superior northward of the Isles Royal and Phelippeaux, to the Long Lake; thence through the middle of said Long Lake, and the water communication between it and the Lake of the Woods, to the said Lake of the Woods; thence through the said lake to the most northwestern point thereof, and from thence on a due west course to the river Mississippi." On the east the boundary was to be a line "drawn along the middle of the river St. Croix, from its mouth in the Bay of Fundy to its source, and from its source directly north to the aforesaid Highlands, which divide the rivers that fall into the Atlantic Ocean from those which fall into the river St. Lawrence."

These terms are identical with those earlier used in the provisional articles of peace concluded November 30, 1782, and the discussion of the reasons for their adoption belongs to an earlier period of history. At this time it will be necessary to confine ourselves to a consideration of the problems to which the treaty of peace gave rise, and of the methods used in adjusiing the differences in regard to boundary, which, in I842, were as old as the nation itself.

The question of the northeastern boundary may be described as a purely geographical question. The successive negotiations for the settlement of the boundary for sixty yafs after the treaty was signed proceeded "upon the theory that the points described in the treaty were capable of being definitely determined and located. In other words, sixty years were spent in an attempt to elucidate the terms of the treaty, a period which has been properly characterized as one of "uncertainty and danger." The line as set out in the 
treaty was "drawn in much ignorance of geography and in trustful dependence in some parts on anterior definitions of the bounds intended." ${ }^{2}$ The American negotiators, Adams, Franklin, and Jay, were deficient in exact knowledge of the places mentioned in the treaty, partly on account of inadequate information as to what had been definitely ascertained, but more on account of the inaccuracy of the maps that they used. This inaccuracy of the maps almost immediately presented questions of dispute. The first was: "Which of the several rivers running into the Bay of Fundy is the St. Croix mentioned in the treaty?" Second: "Where is the northwest angle of Nova Scotia to be found?" Third: "What, and where, are the Highlands along which the line was to run, from the northwest angle of Nova Scotia to the northwesternmost head of the Connecticut River?" Fourth: "Which is the northwesternmost head of the Connecticut River?" and finally: "Are the rivers emptying into the Bay of Fundy those which 'fall into the Atlantic Ocean,' in the words of the treaty?" 3 To state it otherwise, the whole of the boundary, as agreed upon by the peace commissioners, from the Atlantic Ocean to some point in the forty-fifth parallel of latitude, west of the Connecticut River, was scarcely a boundary at all. It was like a deed, which, although purporting to convey land by metes and bounds, is based upon inaccurate surveyor's notes. Until I 842 diplomatic activity was directed in unsuccessful efforts to explain the boundary

${ }^{2}$ Winsor, Narrative and Critical History of America, VII., I7I.

${ }^{3}$ Webster's Defence of the Treaty of Washington, Works, V., 82. 
line to the satisfaction of both countries, to restate the old line, rather than to redetermine it.

The question as to what river the treaty meant by the St. Croix was eliminated from the controversy as a result of Jay's treaty, which provided that the United States and Great Britain should each appoint a commissioner and the two thus appointed select a third. This board of commissioners was given power to take evidence and make surveys, and its finding was to be conclusive "so that the same should never be called in question or made the subject of dispute or difference between them." The commissioners met and reported. A decision was made as to what was the true St. Croix; the source of this river was found and a monument placed there."

Thus one portion of the dispute was removed, and an attempt was made by Jefferson in 1802 to settle the remaining questions through Rufus King, the American minister at London. King was instructed to press for the extension of the line from the source of the St. Croix. "In fixing the point at which the line is to terminate, and which is referred to as the northwest angle of Nova Scotia, the difficulty arises from a reference of the treaty of I 783 to the 'Highlands,' which

"Great Britain claimed that the Magaguadavic was the St. Croix of the treaty; the United States insisted upon the Schoodiac. The commission under Jay's treaty adopted the American claim. Moore, International Arbitrations, I., Chapter I, "The Saint Croix Commission;" American State Papers, Foreign Relations, I., 486, 488, 492, 493, 520; Webster, Works, V., 82. Explanatory article to Jay's treaty, releasing the commissioners under the fifth article from particularizing the latitude and longitude of the river St. Croix; in Treaties and Conventions between the United States.and Other Powers, I889, 396. 
are now found to have no definite existence." "The instructions suggested that commissioners, appointed as in Jay's treaty, should determine upon a line to be substituted for that following the crest of what the former treaty called the Highlands, from the northwest angle of Nova Scotia to the northwesternmost source of the Connecticut River, that line to be drawn with such references to intermediate sources of rivers or other landmarks as to admit of easy and accurate execution. In the negotiations which followed, King and Lord Hawkesbury agreed upon the northeastern boundary in terms substantially those of Madison's instructions. The treaty provided for the running, instead of the mere description, of the line between the northwest corner of Nova Scotia and the source of the Connecticut River. ${ }^{\circ}$ Such an arrangement was eminently desirable, and so, too, might have been a further provision which King and Hawkesbury included in reference to the northwestern boundary beyond the Lake of the Woods. ${ }^{7} \quad$ Between the time the treaty was agreed upon and its formal signing Livingston and

- This is the first official intimation that the boundary as set forth in the treaty of 1783 was incapable of being determined. Madison thus "conceded a point which it was never possible to regain." Moore, International Arbitrations, I., 68. Gallatin long afterward expressed regret that the United States had so blundered. Adams, Gallatin, II., 546. Quoted by Moore, ut sup.

'Madison to King, June 8, I802, American State Papers, For. Rel., II., 585; J. C. B. Davis's notes in Treaties between the United States and Other Powers, 1324, and references there given; Moore, International Arbitrations, I., 65-69; American State Papers, II., 584-9I.

${ }^{7}$ Article 5 of treaty. American State Papers, For. Rel., II., 584 . 
Monroe had secured the cession of Louisiana. The Senate struck out the article referring to the northwestern boundary upon the ground that it might limit the claims of the United States to the territory acquired from France. ${ }^{8}$ Madison believed, as did Monroe, and probably also many in the Senate, that the United States had succeeded to the claim of France under the treaty of Utrecht. "We have reason to believe," wrote Madison to Livingston, "that the Northern boundary was settled between France and Great Britain by Commissioners appointed under the treaty of Utrecht, who separated the British and French territories west of the Lake of the Woods by the 49th degree of latitude." "But there is no evidence, either in the French or British archives, that a boundary commission under the treaty of Utrecht agreed upon such a line.

With the failure of King's treaty the controversy rested until after the War of $1812 .{ }^{10}$ In the prolonged negotiations which led to the treaty of Ghent the questions of boundary filled a large place. Any adequate

'The treaty was agreed upon April II, I803 (King to the Secretary of State, December 9, 1803. American State Papers, For. Rel., II., 59I), and signed May 12, I803. The Louisiana treaty was signed April 30, 1803, but King knew nothing of it until May I5. The Senate consented to the ratification of the King treaty after it had expunged the fifth article. Ratifications of the amended treaty were never exchanged. Am. State Papers, For. Rel., II., 584.

'Madison to Livingston, Jan. 31, I804; Am. State Papcrs, For. Rel., II., 574 .

${ }^{10}$ A negotiation begun by Monroe and Pinkney in 1807 upon the subject of the northern and northeastern boundaries was interrupted by the Leopard-Chesapeake occurrence. $\mathrm{Am}$. State Papers, For. Rel., III., 162-65, 185. 
treatment of the subject would involve a greater space than can be given it here. ${ }^{11}$ The British commissioners early stated that they were authorized to revise the northern boundary, but at first they expressly disclaimed any intention of acquiring any increase of territory, saying that they desired a revision merely to prevent uncertainty and dispute. ${ }^{12}$ The purpose of this revision was soon disclosed, however, when the British commissioners demanded a direct communication from Halifax to Quebec by a cession of that portion of the territory claimed by the district of Maine and of a part of the so-called "Highlands," which intervened between the places named and prevented that communication. This proposal was rejected, the American commissioners denying any authority to cede any part of the territory of the United States. ${ }^{18}$ To this it was replied that the boundary of Maine had never been ascertained, that possession by the United States of the territory never occupied which interrupted communication be-

${ }^{11}$ Moore, International Arbitrations, I., 69-72; Am. State Papers, For. Rel., III., 695-748; IV., 808-II.

${ }^{12}$ The American Commissioners to Monroe, August I2, I8I4; Am. State Papers, For. Rel., III., 705. Protocol of August 8, I814; ibid., 708.

${ }^{18}$ The American Commissioners to Monroe, August 19, I8I4; Am. State Papers, For. Rel., III., 709. Moore, I., 69. "It must be admitted that the propositions and the explanations of the British commissioners did not fit well together. It was they themselves who brought forward the subject of the boundaries; and they at the outset proposed a 'variation' of the line for a specific purpose. Nor had the American government 'asserted' any boundary line but in the language of the treaty of 1783 ." But compare Madison's opinion that the Highlands had no definite existence. The American Commissioners to the British Commissioners, August 24, 1814; Am. State Papers, For. Rel., III., 712. 
tween Halifax and Quebec was not contemplated by the treaty of $1783 .{ }^{14}$ The American representatives thereupon took the ground, which was afterward maintained by the United States, that there was no uncertainty in the terms of the treaty of 1783 , and that nothing further was required than that the boundary line so described should be definitely ascertained by surveys. So the matter stood until the American commissioners submitted a projet of a treaty. In it a stipulation was inserted for the location of the boundary line from the St. Croix through the Highlands to the head of the Connecticut River, or to the forty-fifth parallel, by commissioners named and acting similarly to those appointed to determine the true St. Croix under Jay's treaty. This stipulation was agreed to by the British plenipotentiaries. ${ }^{15}$

The temper of the negotiation, however, marked a new stage in the northeastern boundary contention. The war had demonstrated to Great Britain the desirability of communication overland between Halifax and Quebec, and her demand was based upon that fact. On the other hand, the American commissioners took the firm position that no part of the district of Maine could be ceded, a position which was hostile to the spirit of compromise. Not until I82I did the commissioners, appointed under the treaty of Ghent to determine the boundary line, finish their work and then only by agreeing to disagree, each making a separate report

${ }^{14}$ The British Commissioners to the American Commissioners, September 19, 1814; ibid., 717-18.

${ }^{15}$ Articles 5 and 6, Treaties and Conventions, 402; Davis's Notes, ibid., 1329; Decision of the Commissioners under the Sixth Article of the Treaty of Ghent, June 18, 1822; ibid., 407. 
to his government. ${ }^{16}$ Thus the matter stood as it had since 1794 until 1823, when the United States again began, through Rush and afterward through Gallatin, the negotiations which resulted in the treaty of $1827 .^{17}$ In this, resort was had to the arbitration of a friendly sovereign, or state, as was provided by the treaty of Ghent, in case the commissioners thereunder finally disagreed. This arbitration convention of 1827 set forth with definiteness the method of submitting the case for arbitration. Each side was to prepare a statement of its case together with all the documents bearing thereon, with the understanding that Mitchell's map, which was used by the framers of the treaty of I 783 , and an agreed map of later date (upon which the watercourses were shown) were to be the only maps to be admitted as evidence. ${ }^{18}$ Gallatin, who negotiated the treaty and afterward prepared the American statement of the case (probably the most complete ever made), correctly predicted the outcome of the arbitration, which was referred to the King of the Netherlands, when he reported that, in his judgment, "an umpire, whether he be King or farmer, rarely decides on strict principles of law: he has always a bias to try, if possible, to split the difference." Such a decision, indeed, was made by the judge early in $183 \mathrm{I}$. Of the twelve thousand square miles in controversy,

${ }^{16}$ American State Papers, For. Rel., V., I38-39; VI., 821, 893945, 999-1000; Davis, Notes, I329; Moore, International Arbitrations, I., 72-83.

${ }^{17}$ Am. State Papers, For. Rel., VI., 643, 700-6; Adams, Gallatin, II., 544-45; Moore, Int. Arbitrations, I., 85-138.

${ }^{18}$ Treaties and Conventions, 429. 
about eight thousand were given to the United States. ${ }^{10}$ The state of Maine, which had taken strong ground against the encroachment of Great Britain and had memorialized Congress upon the subject, refused to agree to the decision of the arbitrator. Jackson was in favor of adhering to the decision of the King of the Netherlands. The constitutional objections to the cession of territory belonging to, or at least claimed by, a state was not seriously considered by Jackson, who, before making any offer to Maine of a land grant in the west as a douceur for its concession, was determined to accept the award of the King of the Netherlands as final and to issue his proclamation so announcing it, without consulting the Senate. It is stated, upon the authority of Forsyth, that Jackson was driven from this course by the representation of his friends in Maine, who said that such a proceeding would lose the state to the Democratic party. Jackson was further reported to have said that "it was somewhat singular, that the only occasion of importance in his life in which

${ }^{10}$ Award of the King of the Netherlands; Moore, op. cit., I., II9-36. In the place of the line of the Highlands a conventional line was suggested by the arbitrator because, while the term "Highlands" was applicable to a watershed even though it might not be mountainous, or even hilly, it was not shown that the boundaries described in the treaty of 1783 coincided with the ancient limits of the British province, nor in fact did the line of the Highlands as claimed by either Great Britain or the United States answer the requirements of that treaty. The British claim as to the northwesternmost head of the Connecticut was allowed. Admitting that Rouse's Point was within British territory, the award recommended that "the United States be left in possession of it." The award was thus "recommendatory rather than decisive." 
he had allowed himself to be overruled by his friends, was one of all others in which he ought to have adhered to his own opinions." ${ }^{20} \mathrm{He}$ then proposed that Maine should accept a million acres of public land in the West as an equivalent for the territory claimed by her beyond the line designated by the award of the Dutch king. Nothing came of the proposal. ${ }^{21}$ The results of the arbitration were unsatisfactory to Great Britain and the award was rejected. ${ }^{22}$ From this time until Tyler's administration nothing was done looking toward the settlement of the northeastern boundary question beyond an intermittent correspondence, which grew more and more bitter in tone. Frequent clashes upon the border, which resulted in the so-called "Aroostook War" of 1839, together with the feeling against Great Britain growing out of the Caroline and McLeod cases and the domineering attitude of Lord Palmerston's ministry, tended to bring the relations between the United States and Great Britain to a state of high tension, and such it was when Webster succeeded Forsyth as secretary of state.

Buchanan, as chairman of the Senate committee on foreign relations, reported April I4, I840, and thus stated the position of the Van Buren administration,

${ }^{20}$ Webster, Diplomatic and Official Papers, Introduction, IX.; Benton's Speech, Cong. Globe, 27 Cong., 3 Sess., App., 5; Webster, Works, V., 97, note; Sen. Ex. Doc. 3, 22 Cong., I Sess.

${ }^{21}$ Moore, op. cit., I., I38; Sen. Ex. Doc. 43I, 25 Cong., 2 Sess. In 1832 an agreement to this end was entered into by Livingston, McLane, and Woodbury on the part of the United States and by Preble, Williams, and Emery on the part of Maine, but no ratification followed.

${ }^{22} \mathrm{Br}$. and For. State Papers, XXII., 772, 776, 783. 
with which the committee was in accord: "The territorial rights of Maine have been uniformly asserted, and a firm determination to maintain them has been invariably evinced; though this has been done in an amicable spirit. So far as the committee can exercise any influence over the subject, they are resolved that if war should be "the result, which they confidently hope may not be the case, this war shall be rendered inevitable by the conduct of the British Government. They have believed this to be the surest mode of uniting every American heart and every American arm in defense of the just rights of the country.

While the Committee can perceive no just cause at the present moment for anticipating hostilities between the two countries, they would not be understood as expressing the opinion that their country should not be prepared to meet any emergency." ${ }^{23}$ This was hardly the attitude to take if a successful plan of arbitration was to be arrived at. Fox's projet for an arbitration treaty was followed by Forsyth's counter-projet in August, I840, and Fox referred it to Palmerston. Webster thus described the last stage of Van Buren's negotiation: "Lord Palmerston would have nothing to do with [Forsyth's counter-projet]. He would not answer it; he would not touch it; he gave up the negotiations in apparent despair. Two years before, the parties had agreed on the principle of joint-exploration, and the principle of arbitration" as a faithful adherence to the stipulations of the treaty of Ghent. "But in their subsequent correspondence, on matters

\footnotetext{
${ }^{23}$ Reports of the Senate Committee on Foreign Relations, V., 6or.
} 
of detail, modes of proceeding, and subordinate arrangements, they had, through the whole two years, constantly receded farther, and farther, and farther from each other. They were flying apart; and, like two orbs moving in opposite directions, could only meet after they should have traversed the whole circle." ${ }^{24}$

Early in March, I839, Forsyth, tiring of the interminable discussion of the northeastern boundary quest1on. suggested to the President that Webster be sent to England as a special envoy to take charge of the embarrassing negotiations and to endeavor to frame a treaty which would effectually remove all causes of irritation. Webster was not displeased at the suggestion, although it came from his political opponents, and at once drew up a scheme for the settlement of the boundary question, which he submitted to the secretary of state. Forsyth's suggestion was not adopted by Van Buren. Webster, however, outlined a plan for the settlement, of which three years afterward he, himself, made use. Curtis, in his life of Webster, says that he had been unable to find the sketch of Webster's scheme, though he knew such a one had been in existence. ${ }^{25}$ Dr. Van Tyne, in his recently printed "Letters of Daniel Webster," has supplied the deficiency. ${ }^{20}$ When Webster became secretary of state and began the consideration of the boundary question, he adopted mutatis mutandis the scheme which he had submitted to Forsyth three years before. The plan proposed

"Webster, Works, V., 93.

${ }^{23}$ Curtis, Life of Webster, II., 3, note.

${ }^{28}$ Van Tyne, Letters of Daniel Webster, 215. 
that the negotiation should be conducted from the first in a manner at once informal and conciliatory, and that the case of the United States should be presented as concisely as possible, in order that England should be bound to take her ground, either by asserting a line conformable to her interpretation of the original treaty, as she had done prior to the former arbitration, or else by assuming the position that, owing to the indefiniteness of the description in the treaty, the boundary line could not be found. If she adopted the first position, the United States should show how impossible it would be to reconcile Great Britain's pretensions with the terms of the treaty; if the second, the United States should urge the ex parte surveys, especially the one made by the state of Maine. "But," Webster continued, "however the argument may stand, it is probable that England will not, gratuitously, yield her pretensions and something must be yielded by us, since the subject has actually become matter of negotiation. A conventional line, therefore, is to be regarded as a leading and most promising of adjustments," to which the consent of the state of Maine should be first had. Only in case a conventional line could not be agreed upon should recourse be again had to arbitration. That it would be necessary to gain the previous consent of Maine and Massachusetts to any settlement was not a new idea with Webster. Van Buren had already attempted it, ${ }^{27}$ and so had Jackson after the award of the King of the Netherlands. Nor was the proposition to adopt a conventional line instead of standing upon

${ }^{27}$ Moore, Int. Arbitrations, I., I40; S. E.x. Doc. 319, 25 Cong., 2 Sess. 
the terms of the original treaty a new one. The King of the Netherlands had suggested a conventional line. The germ of the idea is referable to Madison, who believed that the Highlands had no existence. In I 838 Forsyth, as Van Buren's secretary of state, sounded the government of Maine upon its willingness to agree to a conventional line in preference to another resort to arbitration. The legislature of that state answered that it was equally opposed to a conventional line and to a new arbitration; the occupation of all the territory claimed by it was insisted upon.

Palmerston's suggestion, made after the repudiation of the arbitration award, that the disputed territory be equally divided, even if seriously made, was not considered by the United States. ${ }^{23}$ It can hardly be called a proposal for a conventional line. The adoption of a conventional line would have been as if two parties who had fallen out over a contract, the impossibility of a proper performance of which had been demonstrated, were to agree to a supplementary contract, reaffirming the terms of the original agreement in so far as that was possible, and coming together upon new terms in place of those found impossible of execution. In other words, a new boundary treaty should define the terms of the former instrument without dependence upon any interpretation which might have been placed upon that earlier treaty by either party or by a tribunal of arbitration. Webster's plan was essentially a nonlitigious one; concession upon one side implies concession upon the other. The impracticability of his idea was that it was essentially a compromise. The

${ }^{25}$ Walpole, History of England, Ed. I89o, V., 328. 
danger of all quid pro quo treaties is that popular approval of them is difficult to obtain. Reference to arbitration was a programme of litigation pure and simple, by which each side would be sure to claim everything possible in the hope that the award of arbitration would be a compromise of conflicting pretensions.

Van Buren's administration, instead of adopting Webster's plan because blocked by the opposition of Maine, again proceeded upon the theory that arbitration was the only method of solution. Webster, with some show of partisanship, thus characterized the negotiations immediately prior to his taking office: "The merits of the boundary question were never discussed by Mr. Van Buren to any extent. The thing that his administration discussed was the formation of a convention of exploration and arbitration to settle the question. . . . the whole correspondence turned on the arrangement of details of a convention for arbitration. . . . It was because these subordinate questions respecting the convention for arbitration had got into so much perplexity, were so embarrassed with projects and counter-projects, had become so difficult and entangled; and because every effort to disentangle them had made the matter worse," that the Van Buren negotiation came to nothing. "It was an endless discussion of details and forms of proceeding in which the parties receded farther and farther from each other every day." 20

The northeastern boundary controversy was but one of the legacies left by the administration of Van Buren. The McLeod case, the seizure of the Caroline, and the

${ }^{20}$ Webster, Works, V., II4. 
question of right of search in connection with the suppression of the slave-trade-each one of these had been discussed by Great Britain and the United States in such a manner as to arouse the bad feeling that might end in war. The truculent attitude of Lord Palmerston and the large number of British troops despatched to Canada aggravated the unfriendly, if not hostile, demeanor of the American people. On the other hand, the English were embittered by their losses in American securities through repudiation and bankruptcy, and were disgusted by the sundry descriptions of American manners and domestic institutions which travelers such as Mrs. Trollope and Miss Martineau had printed. American'society was represented to be a compound of vulgarity, brutality, and dishonesty in which the evils of slavery, rampant speculation, bankruptcy, and repudiation filled a large place. Added to these elements of discord was the jealousy with which the growing power and importance of the United States were looked upon. The temper of both peoples was irritable and, without a decided change in diplomatic manners, might have led to war.

The case of McLeod and that of the Caroline were clusely connected and grew out of the Canada uprising of 1837 . The circumstances of each, so important constitutionally as well as diplomatically, in which Seward as well as Webster played an important part, remain to be reviewed. The Caroline, an American steamer, had been used in aid of the Canadian rebellion. An expedition from Canada crossed the river, cut the vessel loose from her moorings on the American side, fired her, and sent her down over Niagara Falls. During the disturbance an American citizen named 
Durfree was killed. Some time afterward a British subject, Alexander McLeod, was arrested in New York by the authorities of that state for the murder of Durfree. The seizure of the Caroline took place late in December, I837. McLeod was not arrested until November, 1840. The position which Great Britain, at first vaguely, and afterward distinctly, assumed was that the seizure of the Caroline in American waters was an act of public force, which it avowed and justified as a proper and necessary measure of self-defense. If this position (and it was one which could not be denied by the United States) was as correct as it was bold, the arrest and detention of McLeod by civil or criminal powers were in violation of international rights and usages. The immediate release of McLeod was demanded by Fox, the British minister at Washington, upon the ground that the prisoner, while engaged in the Caroline affair, was performing an act of public duty for which he could not be made personally and individually answerable to the laws and tribunals of any country. ${ }^{30} \quad$ That the seizure of the Caroline was an invasion and a violation of the territory of the United States had been the position of Forsyth from the time of the occurrence, but nothing looking toward satisfaction for the act had been accomplished. The arrest of McLeod, nearly three years after the Caroline was burned, aroused the British ministry to such an extent that they overlooked the affront to the United States by the violation of its territory. Avowing responsibility for the former act,

${ }^{80}$ Fox to Webster, March 12, 184I; Webster, Diplomatic and Official Papers, 120-2r. 
Fox formally and peremptorily demanded McLeod's release. The method of Fox's negotiation and the language which he employed were not calculated to aid in harmonious intercourse, and his usefulness at Washington was really at an end.

The arrest of McLeod upon a charge of murder awakened all the dormant distrust with which England regarded the United States, and the danger of war was imminent. Webster was informed by a prominent Englishman that there was but one feeling on the subject among all parties and all ranks; if McLeod should be condernned it would be such an outrage upon international justice that the scabbard must be thrown away at once." Cass, the American minister at Paris, then, as always, an Anglophobe, wrote: "I suppose you are aware of the instructions given by the British ministry to their minister at Washington. The subject is no secret here, and was freely spoken of to me by one who knew. If McLeod is executed, the minister is to leave the United States. It is the casus belli. But any sentence short of this is not to lead to this result." "s Again he wrote: "We must not shut our eyes to the fact that a war with us would meet with almost universal support in England." ss Palmerston informed Stevenson that McLeod's execution would be the signal for war.

${ }^{31}$ Vernon Harcourt to Webster, March I2, I84I; Curtis, Life of Webster, II., 62, note.

${ }^{32}$ Cass to Webster, March 5, I84I ; Curtis, Webster, II., 62.

${ }^{33}$ Cass to Webster, March 15, I84I; ibid., 64.

* Bulwer, Palmerston, III., 46, 49. Quoted by Walpole, V., 332. 
The temper in Washington, which Fox's note to Forsyth aroused, boded trouble. A hostile report was made in the House by the committee on foreign relations, which suggested the advisability of arming the country. This report was referred to the committee on military affairs, where it fortunately slept while the Van Buren administration went out of office and the Whigs came into power.

The diplomatic misunderstanding was not confined to this side of the Atlantic or to the somewhat arrogant manner of Fox. The United States minister at the Court of St. James was Andrew Stevenson. After twelve years' service in Congress, seven of which were as speaker of the House, he was appointed minister to England by Jackson and was continued in that capacity until Van Buren's term ended. During the last part of his mission he was engaged in a discussion with Lords Palmerston and Aberdeen upon the African slave-trade and the right of visitation and search. These were allied questions which the United States met with growing sensitiveness, a sensitiveness which was the keener from the realization that this country, while committed to the suppression of the slave-trade by a long series of official expressions, found itself disinclined, on account of its domestic institution of slavery, to coöperate with the other nations of Christendom for the effectual abolition of the trade. ${ }^{35}$ The European view, first adopted by Great Britain, was that the trade could not be wiped out without some concession involving a mutual right, if not of search, at

${ }^{25} \mathrm{Du}$ Bois, The Suppression of the African Slave-Trade, passim. 
least of visitation, of merchant vessels suspected of being slavers. As stated by Du Bois: "If a fully equipped slaver sailed from New York, Havana, Rio Janeiro, or Liverpool, she had only to hoist the Stars and Stripes in order to proceed unmolested on her piratical voyage; for there was seldom a United States cruiser to be met with, and there were, on the other hand, diplomats at Washington so jealous of the honor of the flag that they would prostitute it to crime rather than allow an English or a French cruiser in any way to interfere." ${ }^{38}$ Without doubt, the contention of the United States as to England's pretensions to a right of visit was technically correct. This was a position taken by authorities in international law with almost perfect unanimity. Nevertheless, it was clear that if the slave-trade was to be suppressed, each nation must zealously keep her flag from fraudulent use or, as a labor-saving device, must depute this duty to others for limited places and in special circumstances.

In connection with his protest against any visitation of vessels flying the American flag, even though they might be known to be slavers and pirates under federal law, Stevenson told Palmerston in $184 \mathrm{I}$ "that there is no shadow of pretense for excusing, much less justi-• fying, any such right. That it is wholly immaterial whether the vessels be equipped for, or actually engaged in, slave traffic, or not, and consequently the right to search or detain even slave vessels must be confined to the ships or vessels of those nations with whom it may have treaties on the subject." ${ }^{37}$ That the

${ }^{36}$ Ibid., I43.

${ }^{87}$ H. Ex. Doc. 34, 27 Cong., I Sess., 5-6, quoted by Du Bois, 145. 
United States would not be included among nations of this last class was evident from Forsyth's statement that this country had determined not to become a party to any convention on the subject of the slave-trade. ${ }^{23}$

Such was the unsatisfactory condition of affairs with Great Britain with which Webster had to deal upon his entering into the office of secretary of state. Harrison had intended offering the state portfolio to Clay and that of the treasury to Webster. Clay declined any position whatever in the Whig administration. Webster's own inclination was not to accept an appointment from Harrison, unless it might be the post of minister at the Court of St. James, but upon the tender by the President of either the state department or the treasury, ${ }^{39}$ Webster chose the former. Soon after his acceptance of the position Webster began the consideration of the problems which were to be attacked as soon as he came into office. He undertook the preliminaries for the adjustment of the boundary question, as he had outlined them to Forsyth three years before, by sounding the authorities of Maine and Massachusetts upon the possibility of their acceptance of a conventional line. ${ }^{40}$

- At the time of Harrison's inauguration, however, the McLeod case was pressing for attention. A week

${ }^{88} \mathrm{Br}$. and For. State Papers, $1834-5,136$, quoted by Du Bois, I42.

${ }^{39}$ Harrison to Webster, December I, 1840, Webster to Harrison, December II, 1840; Curtis, Webster, II., 48, 50.

${ }^{40}$ Webster to Theophilus Parsons, January 28, I84I, same to C. F. Adams, January 30, I84I; Van Tyne, Letters of Daniel Webster, 227-30. Gov. Kent to Webster, February I7, I84I ; Curtis, Webster, II., 59. Webster to Kent, ibid., II., 60. 
after Webster assumed the secretaryship he received the letter from Fox mentioned above, in which the British minister demanded the immediate release of McLeod. Fox declined to notice the peculiar relations of the various states with the federal government, and refused to admit that the separate state was an independent body over which the federal government had no control. He looked to the federal government to right the wrong, as that government was the only one with which foreign powers had to deal. Fox proceeded to state that the British government demanded McLeod's release upon the assumption that he was one of the persons engaged in the capture of the steamboat Caroline, although it believed that he was not, in fact, engaged in that transaction. Whether McLeod was, or was not, a party to the Caroline affair made no difference. $\mathrm{He}$ was held under arrest for trial for his alleged connection with a transaction which the British government avowed to be of a public character, for which the persons engaged in it could not incur private or personal responsibility. ${ }^{41}$ It is questionable if the position assumed by Fox, which his government endorsed, could be sustained by the law of nations if pressed to its logical end. His underlying thesis was that the United States as a nation could not subject to its own municipal laws an alien who had violated such laws if in such violation the alien had express direction and authority for so doing. The British demand for the surrender of McLeod can only be justified on the ground that the attack on the Caroline was

${ }^{41}$ Fox to Webster, March 12, 1841; Webster, Diplomatic and Official Papers, 122-23. 
excusable on the plea of necessity. ${ }^{42}$ This was the view held by Calhoun in the Senate debate upon the subject, and he was supported in it by Lieber and Lawrence. ${ }^{43}$ That the destruction of the Caroline was due to necessity Fox did not claim. Webster expressly denied it, although Ashburton made that plea. Fox put McLeod's alleged action upon the basis of public duty and not upon the ground of necessity. Upon consultation with the President, Webster decided to accept Fox's view of the case, that as the British government had avowed the act of the destruction of the Caroline to be a public act, then McLeod, if engaged in the enterprise, was acting under the authority of his sovereign, and was, therefore, not amenable to the criminal process of the state in which he was arrested.

Unfortunately for the carrying through of the policy based upon this view of the case, the federal government was without power under the law to discharge McLeod, otherwise Webster would have made merely a demand for redress on account of the violation of United States territory, which the scizure and destruction of the Caroline clearly were. McLeod was in the hands of the state authorities of New York and his case had been set for trial in the May following. Upon the receipt of Fox's note, Webster instructed the attorney general to furnish McLeod's counsel with authentic evidence that the destruction of the Caroline had been avowed by the British government as an act of force done by national authority. "You will see," said Webster, "that McLeod has skilful and eminent coun-

${ }^{42}$ Calhoun, Works, III., 618.

${ }^{43}$ Wharton, Digest of International Law, Art. 2I. 
sel, and . . . that it is the wish of this Government that, in case his defense be overruled by the court, in which he shall be tried, proper steps be taken immediately for removing the cause, by writ of error, to the Supreme Court of the United States." "4

Thus began what might have furnished the Supreme Court with an important constitutional question for its decision, but the course of the courts led in a different direction. Governor Seward denied that he intended to order a nolle prosequi in the case. The government's assistance in McLeod's defense was assailed as an unwarrantable interference by Webster in the internal affairs of the State of New York.

Before Fox's note could be answered Harrison died, and Tyler took up the consideration of the McLeod case as it had been outlined by Webster. The new president approved Webster's plan, which, to restate it, was (I) to stand upon the avowal by Great Britain of the destruction of the Caroline as a public act; and (2) to assist McLeod in making the defense that in taking part in the Caroline imbroglio he was acting under authority, and hence was not amenable to the municipal laws of the State of New York, a plea which Webster believed to be good in law. From this policy he hoped to have two results, (I) the conciliation of Great Britain, by not taking issue on the question of public responsibility; and (2) the avoidance of a clash with the state authorities on a question of jurisdiction. Webster proceeded to answer Fox's note in a manner which, while it delayed the final issue between them

${ }^{4}$ Curtis, Webster, II., 67. 
until the trial of McLeod was had, produced a quieting effect upon Lord Palmerston and the British people."

Webster's answer emphasized the importance with which the United States regarded Fox's explicit avowal. "After this avowal, individuals in it might not, by the principles of public law, be holden personally responsible in the ordinary tribunals of law for their participation in it." Webster then informed Fox that authentic evidence of the avowal by the British government had been furnished McLeod's counsel by the President's direction. "It is now competent for McLeod, by the ordinary process of habeas corpus, to bring his case for hearing before the supreme court of New York. The undersigned hardly needs to assure Mr. Fox, that a tribunal so eminently distinguished for ability and learning as the Supreme Court of the State of New York, may be safely relied upon for the just and impartial administration of the law in this as well as in other cases." "Much to Webster's disgust, however, the writ of habeas corpus was denied and McLeod was remanded for trial. The supreme court of the State of New York, in an opinion which was severely criticised, denied the doctrine that an individual alien can escape personal responsibility for an act if the sovereign of that alien avows the act as a public one. McLeod's counsel dropped Webster's defense and in October proceeded to trial, resting upon an alibi. Perhaps never has this much abused defense done better service. The alibi was proved, McLeod was acquitted, and the casus belli removed as far as

"John Quincy Adams, Memoirs, XI., 21.

“ Webster to Fox, April 24, 184I; Webster, Diplomatic and Official Papers, 127. 
McLeod was concerned. The grievance of the United States against Great Britain for the violation of its territory by the seizure of the Caroline remained to be adjusted. In order to prevent future arrests by state authorities of aliens accused of acts for which their sovereign accepted responsibility, Webster drafted a law which was passed by Congress in August, I842. This statute gave the federal courts power to grant writs of habeas corpus in all cases where aliens were confined in jail on account of any act done under the authority of a foreign state, the validity of which would depend upon the law of nations."

John Quincy Adams noted in his diary that the end of the McLeod case relieved the United States from all immediate danger of hostile collision with Great Britain, but left the negotiations with that country "upon the Maine boundary, the South Sea boundary, the slave-trade and the seizure of our ships on the coast of Africa thorns to be extracted by purer and more skilful hands than are to be found in the Administration of John Tyler." \&s The fall of the Melbourne ministry, of which Lord Palmerston had been the foreign secretary, and the formation of a cabinet under the premiership of Sir Robert Peel, with Lord Aberdeen as minister of foreign affairs, laid the foundation for a better feeling between the two countries. Out of it came the special mission of Lord Ashburton, to whom, with Tyler and Webster, the credit is due for the removal of the thorns which John Quincy Adams believed could not be removed.

"Unitcd States Compiled Statutes (190r), Section 763.

“ John Quincy Adams, Memoirs, XI., 27. 


\section{CHAPTER II}

\section{The Ashburton Treaty}

The valedictories of Palmerston as foreign secretary under Melbourne and of Stevenson as Van Buren's envoy were not calculated to make the problems which confronted their successors any easier of solution. Following immediately upon the writing of Palmerston's note to Stevenson, in which he upbraided the United States for its practical, if not intentional, double-dealing in reference to the suppression of the slave-trade, the Liberals were defeated in Parliament ${ }^{1}$ and Sir Robert Peel was sent for by the Queen to undertake the formation of a new government. In it Lord Aberdeen, who had held the same position from I828 to I830, was made foreign secretary. A brilliant historian of our own day has thus contrasted the fall from power of the Whigs under Melbourne with the earlier government of Grey: "The heroic measures which the Whigs promoted under Grey lost them the support of their more timid followers. The constant concessions which emasculated their policy under Melbourne estranged from them earnest reformers. The

${ }^{1}$ Palmerston to Stevenson, August 27, 1841. This was answered by Stevenson in a note addressed to Aberdeen, October 10, 184I, the day Stevenson left London. Everett's introduction to Webster's Diplomatic and Official Papers, VII. Edward Everett was appointed in Stevenson's place July 24, I84I, but was not presented until the following December. Webster to Cass, April 5, I842; Curtis, Webster, II., I84. 
history of the Whigs under Grey thus becomes a chronicle of great successes; their history under Melbourne is a story of compromises. There are few things more exhilarating in history than the annals of the Whigs under the one minister; there are few things more disheartening than the story of their decline and fall under the other. Under Grey the Whigs lost their popularity, but they retained their credit. Under Melbourne they lost their credit without recovering their popularity." 2 As to Palmerston's foreign policy, however, a decided exception is made. Palmerston's policy, fortiter in re but not suaviter in modo, was undeniably popular in England. Much of what in later days has been called jingoism was a large ingredient in the foreign policy of the Whig statesman. That it added to the already unpleasant feeling between the United States and Great Britain robbed it of no popularity in England. None of the questions at issue between the two countries was of transcendant importance to the British mind. "A policy which had foiled the French, and produced a fresh naval victory [i. e., Napier's over Miguel, off Cape Saint Vincent, July 2, I833] was seen to be popular," says the same writer, Walpole. "The consistency, moreover, which Palmerston had displayed from first to last, the firmness with. which he maintained his opinions, the promptitude with which he had acted on them was calculated to make a profound impression upon the public mind. Every one knew the difficulties which he had successfully surmounted, the faint support which the ministry was receiving from Parliament, and the rabid oppo-

'Walpole, History of England, IV., 226. 
sition of the French nation. It was natural in these circumstances that the fame of the British foreign minister should be raised to an extraordinary height by the skill of his plans and the vigor of his blow. Throughout Europe, throughout the East, throughout Britain itself, the name of Palmerston was on every lip. He had raised the honor of Great Britain to a level which it had not reached since the days of Waterloo. Other statesmen had won unanimity by concession; he alone had won unanimity by success." Stripped of the phrase of panegyric, all this means that under Palmerston, as under later statesmen on both sides of the Atlantic, jingoism was popular.

Palmerston's attitude had resulted in the rabid opposition of the French to the English nation, as Disraeli noted, and it was one of Peel's first duties to overcome this feeling. Although it had been said that Aberdeen was less liberal in his foreign policy than his predecessor," his first endeavor was to smooth away all the bad temper to which Palmerston's aggressive asperities had given rise. Under Palmerston everything was directed toward diplomatic victories for England; Aberdeen's policy was to lay the foundations for a better understanding on the part of England and other nations. The fruits of this policy were soon seen in the negotiation which resulted in the signing of the quintuple treaty by Great Britain, France, Prussia, Austria, and Russia, December 20, I84I.

By this treaty the four continental powers agreed to adopt the British laws relating to the slave-trade and gave to each other a partial right of search. "It

'Ibid., IV., 334 . 
was," said Aberdeen to Everett, "in truth a holy alliance, in which he would have rejoiced to see the United States assume their proper place among the great powers of Christendom foremost in power, wealth, and civilization and connected together in the cause of mercy and peace." " This was as much of an overture as was made to have the United States join the five European powers in a combined effort to put down the slave-trade. The tone of this letter of Aberdeen was conciliatory in the extreme. It purported to be an answer to Stevenson's letter of October 2I, and as it was the first expression of the new government upon the question of search, it is of great importance. Written upon the same day upon which the quintuple treaty was signed, it shows strikingly how the policy of Aberdeen differed from that of Palmerston. At the outset he abandoned the position of his predecessor, and renounced the idea that the right of search was, except under positive treaty stipulations, anything but a belligerent right. Basing his position upon the fact that slavers were usually provided with two sets of papers, one of which was frequently American, he stated that the sole purpose of British cruisers was to ascertain whether vessels met with were really American, or whether they were of another nationality fraudulently provided with a set of American papers. It was notorious that the practice of sailing with double sets was a growing one. Trist, the American consul at Havana, was charged with making a regular business of providing Brazilian and other slavers with false

4Aberdeen to Everett, December 20, 1841; Webster, Diplomatic and Official Papers, I45. 
American papers, and upon investigation he was removed. It is undeniable that the American flag was a cloak for the slavers, and the sensitiveness of the American government over any exercise of the right of visitation or search gave slavers practical freedom. There was no chance of being interfered with unless by a vessel of the American navy, and these were few and far between. It was a question whether the United States cared more for the rigid maintenance of freedom from visitation and search than it did for the suppression of the slave-trade. Memories of the War of 1812 and its causes were responsible for much of the excitability upon the subject, but, strangely enough, the government was much more sensitive than it had been twenty years before, when, except for Great Britain's stubbornness, a mutual right of search might have been agreed upon.

It was for the purpose of putting a stop to the use of fraudulent papers that Aberdeen rested his case. "The right asserted has, in truth, no resemblance to the right of search, either in principle or in practice. It is simply a right to satisfy the party who has a legitimate interest in knowing the truth, that the vessel actually is what her colors announce. This right we concede as freely as we exercise it. The British cruisers are not instructed to detain American vessels under any circumstances whatever; on the contrary they are ordered to abstain from all interference with them, be they slavers or otherwise." " Stevenson had stated that the flag of the United States could protect

${ }^{5}$ Aberdeen to Everett, December 20, I84I ; Webster, Diplomatic and Official Papers, 145. 
only those vessels that were bona fide American. Aberdeen submitted that all Great Britain desired was to stop those slavers that were strongly suspected of fraudulently flying the Stars and Stripes, in order to take such means as were indispensably necessary for ascertaining the truth. In short, the position of Stevenson had been that upon the high seas the fact that a vessel (even if known to be a slaver) flew the flag of the United States was conclusive of its American nationality. Aberdeen's view was that it was only presumptive proof of its nationality; but owing to the notoriously fraudulent use of the flag, when there was strong suspicion of fraud the flag was not conclusive. "The undersigned begs to repeat," wrote Aberdeen to Everett, "that with American vessels, whatever be their destination, British cruisers have no pretensions, in any manner, to interfere. Such vessels must be permitted, if engaged in it to enjoy a monopoly of this unhallowed trade; but the British government will never endure that the fraudulent use of the American flag shall extend the iniquity to other nations by whom it is abhorred and who have entered into solemn treaties for its entire suppression." " Upon the receipt of this note, Webster merely acknowledged its dispassionate tone and forbore any reference to the biting justice of Aberdeen's statement. The strong tone of Tyler's message to Congress at the opening of Congress in December in referring to the Stevenson-Palmerston correspondence is said not to have been the occasion of Aberdeen's pronouncement.

Cass, the American minister at Paris, claimed to be, and doubtless was, informed as to the current of poli- 
tics, English as well as continental. His long enduring hatred of Great Britain, however, made him suspicious of her every motive. Why, he thought, should Great Britain enter into a treaty for the suppression of the slave-trade with four continental powers of Europe, none of which, save France, had important maritime interests or the remotest connection with the slave-trade? It could only be the purpose of Great Britain to arrogate to herself the right to police the high seas, and so to menace the freedom of the United States upon the ocean. He, therefore, upon his own responsibility, addressed a communication to Guizot, Louis Philippe's prime minister, protesting against the ratification by France of the quintuple treaty in terms as vigorous as they were presumptuous. Cass's letter to Guizot quoted Tyler's message to Congress in which it was stated that however desirous the United States might be for the suppression of the slave-trade, it could not consent to such interpolations into the maritime code at the mere will and pleasure of other governments. "We deny," said the President, "the right of any such interpolation to any one or all the nations of the earth without our consent. We claim to have a voice in all amendments or alterations of that code, and when we are given to understand [as by Palmerston] that the treaties of a foreign government with other nations cannot be executed without the establishment and enforcement of new principles of maritime police, to be applied without our consent, we must employ a language neither of equivocal import or susceptible of misconstruction." "

'Tyler's First Annual Message, Richardson's Messages, IV., 77. 
That such was the pretension of Great Britain Cass proceeded to point out, and that as a consequence of the quintuple treaty, France might be forced against her will to assume like ground. "Certainly the American government," Guizot was told, "does not believe that the high powers, contracting parties to this treaty, have any wish to compel the United States by force to adopt their measures to its provisions, or to adopt its stipulations. They have too much confidence in their sense of justice to fear any such result; and they will see with pleasure the prompt disavowal made by yourself, sir, in the name of your country at the tribune of the Chamber of Deputies, of any intentions of this nature." Then follows a threat, made all the more amazing by Cass's admission that he was acting without instructions and upon his own responsibility. "Were it otherwise and were it possible the United States might be deceived in this confident expectation, that would not alter in one tittle their course of action. Their duty would be the same and the same would be their determination to fulfill it. They would prepare themselves with apprehension, indeed, but without dismay, with regret, but with firmness, for one of those desperate struggles which have sometimes occurred in the history of the world, but where a just cause and the favor of Providence have given strength to comparative weakness and enabled it to break down the pride of power."

Such was the belligerent answer given to Europe upon the question of the suppression of that slavetrade which the United States had been the first to

- Cass to Guizot, February 13, I842; Webster's Diplomatic and Official Papers, 177. 
condemn as piracy. Cass had preceded his fiery note with the publication of a pamphlet, afterwards famous, upon the right of search. This pamphlet, published in French anonymously, was given wide publicity, and Niles, naming the author, printed it in full in his Register. Wheaton, at Berlin, afterwards printed a fuller examination of the right of search, both taking the position, not denied by England, that the right was only that of a belligerent." There can be no doubt that Cass's pamphlet did a great deal toward arousing French sentiment against the quintuple treaty. Cass was given the credit for defeating the ratification of it by France, but it may be said that this is an overstatement. On the day of the assembling of the French Chambers an amendment to the reply to the King's speech was adopted unanimously. This read: "We have also the confidence that in granting its concurrence to the suppression of a criminal traffic, your government will know how to preserve from every attack the interest of our commerce and the independence of our flag." This amendment was adopted prior to the publication of Cass's pamphlet and also before his note of protest to Guizot was written. It was such a rebuff to Guizot that the ratification of the treaty would have been impossible even if Cass had had no hand in the matter. The vote of the Chambers was the result of a desire to retaliate upon Great Britain for Palmerston's policy toward France, a desire which the friendly feeling of Guizot toward Peel could not overcome.

- Cf., however, Sir Wm. Gore Ouseley's Reply to an American's Examination of the Right of Search, . . . . London, I842. 
Tyler said in reading the newspaper accounts of Cass's action that he approved the course taken, based, as it was, upon his annual message. ${ }^{10}$ Webster thereupon wrote Cass of the President's approval of his letter and "warm commendation of the motives which animated him in presenting it." Cass was informed that "without intending to intimate what modes of settling this point of difference with England will be proposed, he might receive two propositions as certain: (I) that in the absence of treaty stipulations, the United States would maintain the immunity of merchant vessels on the seas to the fullest extent which the law of nations authorized; and (2) that if the United States entered into a treaty for the suppression of the trade, the stipulations would be for that single object without embarrassing innocent commerce or being unequal in practical operation." 11

This letter was shown to Guizot and the latter made use of it in framing his answer, which was not written for three months after Cass's note. There was no reason whatever to think that the obligations of the quintuple treaty would be forcibly extended to any nation not a party to that instrument. "I have the less hesitation in here giving the formal, and in my opinion entirely superfluous, assurance that the King's Government on its part places the fullest confidence in the firm resolution so often proclaimed by the Federal Government to aid, by its most sincere endeavors, in the definitive abolition of the trade. The

${ }^{10}$ Tyler's Tylers, II., 233.

"Webster to Cass, April 5, I842; Diplomatic and Official Papers, I8r. 
dispatch of Mr. Webster is of such a nature as to increase this confidence. It seems to show, in fact, that the Cabinet of Washington foresees the probability of concluding with the states which have adhered to the right of reciprocal search for the suppression of the slave-trade, arrangements proper to attain the end which they propose. We should attach the more value to this concurrence of views from the circumstance that, while it would hasten the entire destruction of the slave-trade, it would have the effect of piacing all governments in the same situation as regards the measures adopted for its suppression." 12

At about the time of McLeod's acquittal, by which fortunate circumstance a bad matter was mended, with Tyler's authority Webster told Fox, the British minister, that he was prepared to consider the negotiation of a conventional line for the settlement of the longstanding northeastern boundary difficulty. Palmerston had previously instructed Fox that he considered the counter-projet, as prepared by Forsyth, to be unreasonable, undeserving of answer, and as withdrawn from consideration. Fox was thereupon directed to submit Palmerston's original projet to Webster and to persuade the new secretary of state that it was reasonable. But, in Webster's own words, "Mr. Webster was not to be so persuaded; that is to say, he was not to be persuaded that it was reasonable, or wise, or prudent, to pursue the negotiations in this form further. $\mathrm{He}$ hoped to live long enough to see the northeastern boundary settled; but that hope was faint, unless he could rescue the question from the labyrinth of pro-

${ }^{12}$ Guizot to Cass, May 26, I842; ibid., I86. 
jects and counter-projects, explorations and arbitrations, in which it was involved." 18

Webster's overture was not heeded by Palmerston, and that secretary went out of office without an effort to improve the relations between his country and the United States. It may be suspected that such a proposition was not altogether to Palmerston's taste. The adjustment of a boundary dispute of sixty years' standing, by means of a conventional or artificial line, could be done only by compromise and mutual concession, such as might and probably would not be hailed as a diplomatic victory. Not until after Stevenson's departure and Everett's presentation was Webster's overture considered. On the 2oth of December, I84I, the date of the quintuple treaty, Everett was invited by Lord Aberdeen to an interview in which the foreign secretary outlined his plan for the betterment of relations between the two countries. Aberdeen said that in offering to send a special minister to Washington more than an overture to the United States was made, because the minister would go with full powers to make a definitive settlement on every point in discussion between the two countries. "In the choice of the individual for the mission," the secretary added, "he had been mainly influenced by a desire to select a person who would be peculiarly acceptable to the United States as well as eminently qualified for the trust." "14 The selection of Lord Ashburton as the special envoy was an admirable one. During a long life Alexander Baring, as one of the great banking house of Baring

${ }^{13}$ Webster's Works, V., 97.

${ }^{14}$ Everett to Webster, December 3I, I84I ; Webster's Diplomatic and Official Papers, 33. 
Brothers, and as a member of Parliament, and finally as the first Lord Ashburton, had consistently striven for the maintenance of a good understanding between the sections of the English-speaking people on either side of the Atlantic. In a private letter to Webster, written soon after the appointment was announced, Ashburton said: "The principal aim and object of that part of my life devoted to public objects during the 35 years that I have had a seat in one or the other House of Parliament, has been to impress on others the necessity of, and to promote myself, peace and harmony between our countries; and although the prevailing good sense of both prevented my entertaining any serious apprehensions on the subject, I am one of those who have always watched with anxiety at all times any threatening circumstances, any clouds which however small may through the neglect of some or the malevolence of others end in a storm the disastrous consequences of which defy exaggeration." ${ }^{15}$ Lady Ashburton, who was the daughter of William Bingham, a member of the Continental Congress and afterwards a senator from Pennsylvania from I795 to I80I, wrote to Webster that the honors which had been thrust upon her husband came from his being the person most zealous in the cause of America and most sanguine as to the possibility of settling the pending differences between the two countries. ${ }^{16}$

At first Peel's selection was applauded, but upon second thought popular approval was withheld. "Peo-

${ }^{16}$ Ashburton to Webster, January I, I842; Van Tyne's Letters of Daniel Webster, 253.

${ }^{10}$ Lady Ashburton to Webster, January 2, $1842 ;$ ibid., 254. 
ple reflect on his vacillation and irresolution," wrote Greville in his journal, "and think age [Ashburton was then sixty-seven] and absence from affairs are not likely to have cured the defects of his character." ${ }^{\prime \prime}$ But all gave him credit for his sacrifice.

Upon the receipt of Everett's letter containing Aberdeen's proposal, Webster wrote to Reuel Williams, one of the senators from Maine, a Democrat, requesting him to sound the governor, Fairfield, upon his plan of having the government of that state, preferably through commissioners selected by the legislature for the purpose, become a party to the discussions and conclusions which might be had between Great Britain and the United States in the proposed negotiation. "It is our purpose," Webster wrote to Williams, "to put the question in the fairest manner to Maine, whether she will consent to be satisfied with a conventional line and all the other terms and conditions which commissioners of her own appointment shall have approved. No negotiations for such a line will be approved or entered upon without an express previous consent upon the part of Maine, to acquiesce in any line with all its terms, conditions and compensations which shall have been thus previously approved." ${ }^{18}$

Williams replied that although Maine relied upon her claim as just and had, therefore, no desire to change the line of 1783 , he believed that she would release to Great Britain such portion of her territory in controversy as the convenience of the latter might require,

${ }^{17}$ Greville's Journal of the Reign of Queen Victoria, II., 71. ${ }^{18}$ Webster to Reuel Williams, February 2, I842; Van Tyne's Letters of Daniel Webster, 256. See also Webster to John Davis, July (?) I5 (February 15), 1842; ibid., 270. 
on an offer of other territory in exchange or other suitable equivalent, provided it was definitely known before Maine gave any instructions to her commissioners that Ashburton would be authorized to treat for a conventional line. ${ }^{10} \quad$ Webster could only give Williams assurance that he believed Ashburton would be so authorized. On this account, therefore, no definite action could be taken until the precise nature of Aberdeen's instructions was known. The legislature of Maine adjourned without taking any action on the subject.

Lord Ashburton arrived in Washington early in April, 1842, and his definite authority to treat for a conventional line was officially demonstrated. Webster then wrote to Governor Fairfield urging the appointment of commissioners to act as had been suggested to Senator Williams. ${ }^{20}$ The importance of quick action was insisted upon, and he urged that the governor call a special session of the legislature for the purpose. A similar communication was sent to the governor of Massachusetts, ${ }^{21}$ which was equally interested with Maine in the public lands in the disputed territory, although the territorial sovereignty belonged to the latter state. The Maine legislature was called in special session and four commissioners were selected. Massachusetts waived the official information as to Ashburton's authority, and its legislature empowered the gov-

${ }^{10}$ Williams to Webster; ibid., 258.

${ }^{20}$ Webster to Fairfield, April II, I842; Webster's Diplomatic and Official Papers, 36.

${ }^{21}$ Webster to Davis, February 15, I842; Van Tyne's Letters of Daniel Webster, 270. 
ernor and council to adopt any measures which might aid in settling the controversy. ${ }^{22}$

It was Webster's hope that the commissioners would be left free to act without specific instructions, and he sent Jared Sparks to Maine to assist in persuading the legislature to forego instructions. In this errand Sparks was unsuccessful, and the commissioners were directed to assent to no concession to Great Britain of any lands lying within the part claimed by Maine as an equivalent for lands ceded by that state. ${ }^{23}$ Governor Davis of Massachusetts was also inclined to hold fast to the state's claim, saying to Webster that Massachusetts would, "on honorable terms, concede something to the convenience and necessity of Great Britain, but nothing, not a rood of barren heath or rock, to unfounded claims." ${ }^{2 *}$

Such was the unsatisfactory basis upon which Webster had to act when the commissioners met him in Washington on June I3. Until that date no official communication had passed between him and the special envoy. Ashburton's note was unfortunate. He opened the way for controversy, and thus increased the suspicions of the state commissioners, by an elaborate statement of the position of Great Britain. This was done, he stated, in order to correct a certain false impression as to Great Britain's motives, which was that his government's claim dated only from 1814 , when the course of the War of 1812 had demonstrated the neces-

${ }^{22}$ Joint Resolution of Massachusetts Legislature, March 3, 1842; Congressional Globe, 27 Cong., 3 Sess., I2.

${ }^{23}$ Curtis's Webster, II., I02. Cf. Adams's Sparks, passim.

${ }^{24}$ Davis to Webster, April 17, 1842 ; Congressional Globe, 27 Cong., 3 Sess., I2. 
sity of overland communication between New Brunswick and Quebec. ${ }^{25}$

Webster did not rejoin at once with counter-argument, but proceeded to the consideration of a conventional line. Contrary to the usual rule, no minutes were kept of the meetings and no protocols were prepared for the drafting of the treaty. All the letters were written after agreement, and those of Webster to Ashburton were submitted to Tyler and each received his corrections. ${ }^{26}$ During the Senate debates upon the ratification the lack of protocols was objected to by Benton as a departure from precedent not to be tolerated. "Never since diplomacy began and the art of writing was invented, was a negotiation of such moment, or of any moment, so tracklessly conducted," said Benton. The lack of protocols was deliberate. It was Webster's idea that agreement for a conventional line must be approached through informality. Written records meant the argument of contesting claims, the opposite of compromise and concession. Webster's note to Ashburton, dated June I7, said merely that he was authorized and prepared to treat for a conventional line. ${ }^{27}$ Ashburton's reply of the same date proposed a conference upon the subject for the following day. "Long will this day," said Benton to the Senate, "this Friday, June I7, I842, be remembered and noted in the annals of this confederacy.

${ }^{25}$ Ashburton to Webster, June 13, I842; ibid., 4.

${ }^{28} \mathrm{John}$ Tyler to Robert Tyler, August 29, 1858 ; Tyler's Tylers, II., 242.

${ }_{27}$ Webster to Ashburton, June I7, I842; Congressional Globe, 27 Cong., 3 Sess., 5.

${ }^{28}$ Ashburton to Webster, June 17, I842; ibid. 
In the Roman calendar, it would have had a place among their unlucky days. Its memory would have been perpetuated by a black monument and most appropriate will it be for us to mark all the new boundaries of Maine with black stones, and veil with black the statue of the god Terminus, degraded from the mountain which overlooked Quebec, to the humble valley which grows potatoes."

Perhaps this delicious bit of bombast might better have remained embalmed in the pages of the Globe, yet it is a fair sample of the attack made upon Webster's negotiation. Upon that "black Friday," as Benton persisted in calling it, the question of boundary was not settled; the negotiation was but begun. It marked the agreement of the two governments for a conventional line. At the conference of the following day Webster asked Ashburton to state his views of the boundary case and the expectations of his government. This was in accordance with Webster's plan as outlined to Forsyth in 1839: that as soon as possible a place should be found in the correspondence for a clear and concise statement of the case, so that Great Britain would be forced to take a definite position. ${ }^{30}$ Ashburton then prepared and delivered to Webster the British statement. ${ }^{81} \quad$ Their duty was, he stated, to trace a new boundary between Maine and New Brunswick. Great Britain undertook this without any wish of aggrandizement. Her aim was to make a con-

"Ibid., appendix, I4.

${ }^{80}$ Webster's plan; Van Tyne's Letters of Daniel Webster, 216.

${ }^{81}$ Ashburton to Webster, June 2I, I842; Congressional Globe, 27 Cong., 3 Sess., 5. 
venient boundary and not to drive a bargain. He then proposed the following line: the river St. John from where the north line of the St. Croix strikes it, up to some one of its sources, with an exception so as to throw the Madawaska settlements (which he claimed were loyal to Great Britain), scattered along both banks of the river St. John, into the British territory. The point where the line was to leave the St. John was to be decided later with Webster. As a concession to the United States, he offered to accept the line surveyed prior to I774 as the line of forty-five degrees. This line had been shown by later and more accurate surveys to be forty-two seconds of latitude too far to the north. The true line of fortyfive degrees would have thrown Rouse's Point into Canada. This fortunate accident gave Ashburton something to use as a quid pro quo, as, according to strictly accurate surveys, Rouse's Point belonged to Great Britain. A further concession was Ashburton's offer of the free navigation of the St. John. In closing his letter, Ashburton said: "It would have been useless for me to ask what I knew could not be yielded, and I can unfeignedly say that, even if your vigilance did not forbid me to expect to gain any undue advantage over you, I should have no wish to do so."

With the receipt of Ashburton's note, the negotiation came perilously near ending, first, on account of the attitude of the Maine commissioners, second, through the unwillingness of Ashburton to prolong his stay in the United States, and third, on account of the unpleasant turn taken to the discussion of the Creole case, which had claimed attention since the past winter. After the publication of Ashburton's letter 
of June 2I, the Maine commissioners prepared a long statement of the position of their state, which they presented to Webster. In it they said that if Ashburton's claim of the south and west of the St. John was a sine qua non, they would have nothing further to do with the negotiation. The statement, the tone of which was altogether uncompromising, was probably prepared by Preble, one of the commissioners. ${ }^{32}$ Ashburton was so much discouraged by it that it required great tact to keep him from throwing over the business. Webster gave Tyler all the credit for persuading Ashburton to continue it. ${ }^{33}$ Ashburton then appeared to be hampered by fresh instructions, of the precise nature of which Webster was not informed. On the 28th of June Webster reported to Everett that the movement in the negotiation, if any had been made, was backward rather than forward. ${ }^{34}$

The case of the Creole added to Ashburton's embarrassment. The facts in reference to the Creole incident were imperfectly known, but all accounts of the affair were such as to anger the slaveholding states as much as the arrest of McLeod had incensed the people of Great Britain. The American bark, Creole, was en route from Richmond, Virginia, to New Orleans with a cargo of merchandise and slaves. These slaves revolted, imprisoned the officers and crew, and seized the vessel. They then entered the port of Nassau, where they were given freedom and assistance, while the officers and crew were left to take care of themselves. Up to the time of Ashburton's departure

${ }^{32}$ Webster's Diplomatic and Official Papers, 49.

${ }^{33}$ Curtis's Webster, II., I05, note. Tyler's Tylers, II., 218.

"Webster to Everett; Curtis's Webster, II., 104. 
Everett had made no complaint of the matter, and the subject of the Creole, therefore, was not one of the immediate objects of the special mission. ${ }^{35}$ Webster instructed Everett to make a protest to Aberdeen about the liberation of the slaves who had captured the Creole. His position in the matter was doubtless influenced by Story, for whose opinion Webster had informally asked. ${ }^{36}$

"We insist," wrote Webster to Everett, "that in cases of vessels carried into British ports by violence or stress of weather, there shall be no interference from the land with the relation or personal condition of those on board, according to the laws of their own country." ${ }^{37}$ Webster, however, could claim no positive right under the law of nations, and it was not to be expected that Aberdeen would in any wise circumscribe the broad principle that a slave became free when he stepped upon British ground. Everett was told that the United States should protect herself from such occurrences by convoying her coasting of such a character. Webster replied to Everett in a despondent tone. If the boundary question were again to run a course of surveys and arbitrations, and if the United States were to understand that its coasting trade could not enjoy ordinary safety unless put under convoy, the Ashburton mission would end by leaving things much worse than it found them. "I hardly see how this

${ }^{35}$ Ashburton to Webster, August 6, I842; Webster's Diplomatic and Official Papers, 91.

${ }^{36}$ Story to Webster, March 26, I842; Van Tyne's Letters of Daniel Webster, 263. Pierce's Sumner, II., 200; Moore, Int. Arbitrations, I., 410-12, 417.

${ }^{37}$ Webster to Everett, June 28, 1842; Curtis's Webster, II., I06. 
bad result is to be prevented unless we can succeed in beseeching Lord Ashburton to delay his return another month in the hope that the cloud on his brow may be dissipated by the next communication from home." ${ }^{3 s}$

It was Webster's desire that the Creole case might be used as a peg upon which to hang a stipulation for extradition in the treaty in which he hoped the Ashburton negotiation might result. The discussion of a case of this nature was dangerous. In any question in which the domestic institution of the United States was involved might be found a text for antislavery discussion by Aberdeen. Until Ashburton had specific instructions upon the general subject, Webster could not introduce it to him. With this pause in the prosecution of the special negotiation, Webster drafted an answer to Ashburton's letter on the boundary question.

It must be confessed that Webster's reply to Ashburton's well-meant and friendly letter was hardly ingenuous. Ashburton had taken Webster at his word and avoided a long statement of the British case based upon the length of time the various parts of the contested territory were occupied. Waiving all controversial topics except the position of the Madawaska settlements, he then proposed the line of the St. John, with a deviation therefrom to be agreed upon, with concessions as to Rouse's Point and the navigation of the St. John. Webster's rejoinder was an elaborate argument, supporting the proposition that a boundary line might be ascertained, run, and delineated with precision according to the words of the treaty of I783, and he proceeded to demonstrate this by the stock arguments of many years. With this by way of pre- 
face, all doubtless intended as a vindication of the position assumed by the Maine commissioners in a communication addressed to Webster and by him enclosed with his note to Ashburton, ${ }^{30}$ Webster then answered Ashburton's proposal for a conventional line. The United States, he said, would never relinquish any territory west of the north line of the St. Croix and south of the St. John, in which were the Madawaska settlements. He further objected to following the St. John, as the course of the main stream turned back to the south and west toward the Penobscot. "The United States, therefore, would not object, upon the adjustment of proper equivalents, to a line of boundary which should begin at the middle of the main channel of the St. John, where that river is intersected by a due north line extended from the source of the St. Croix; thence proceeding westwardly by the middle of the main channel to a point three miles west of the mouth of the Madawaska; thence by a straight line to the outlet of Long Lake and thence to the highlands which divide the waters of the Rivière Duloup from those falling into the St.

- Francis." This last division was to take the place of the indefinite description in the treaty of I 783 of the Highlands which divide the waters falling into the St. Lawrence from those falling into the Atlantic Ocean. The manner of following the line of the Highlands to the northwesternmost source of the Connecticut, Webster left for a later conference. The line including Rouse's Point he admitted to be a valuable concession, as was the navigation of the St. John.

${ }^{30}$ The Maine Commissioners to Webster, June 29, I842; Congressional Globe, 27 Cong., 3 Sess., I4. 
The apparently inflexible attitude was perhaps intended for home consumption, and his aggressive reiteration of the old arguments may have been mere brutum fulmen. At any rate, the character of the correspondence was at once changed. Ashburton replied to Webster with no more argumentation than was necessary to preserve his dignity and to keep his case from appearing to go by default, closing his letter with this friendly appeal: "The position in which this negotiation now stands, seems to prove what I have before volunteered to advance,- - that it would have a better chance of success by conference than by correspondence; at all events, that we should sooner arrive at ascertaining what we can or cannot do. Slow, unnecessarily slow, our progress has hitherto been; and the public seem, somehow or other, to have become informed that there are differences. I hope, when we come to discuss them, they will prove less serious than they are supposed to be; but it is very desirable that doubts and distrusts should be set at rest, and that public credit and the transactions of commerce should suffer the least possible disturbance." ${ }^{40}$

During the four days following the receipt of Ashburton's letter he and Webster had frequent conferences upon the subject of the boundary. They agreed upon the line as described in the final treaty. On the I $5^{\text {th }}$ Webster submitted the decision to the commissioners of Maine and Massachusetts. For the concessions of public lands which these two states would have to make, in case the compromise line was agreed

${ }^{40}$ Ashburton to Webster, July II, I842; Congressional Globe, 27 Cong., 3 Sess., 9. 
to, he offered the sum of two hundred and fifty thousand dollars to be paid by the United States to Maine and Massachusetts in equal parts. The proposed line, Webster stated, was not all that might have been hoped for, but he believed that no more advantageous arrangement could be made and he asked assent to it. Of the twelve thousand square miles in dispute the new line gave to the United States seven thousand, or about six hundred less than under the Netherlands award. The line followed the St. John to the St. Francis and up that "river to Lake Pohenagamook. "Thence, instead of following the "Highlands," the boundary followed an arbitrary line southwest for a distance of some hundred miles to a point near the southwest branch of the St. John. The crest of hills was then followed to the northwest source of the Connecticut River, known as Hall's Stream, and along the old line of forty-five degrees to the St. Lawrence.

The treaty of peace of $I 783$ had proceeded upon the erroneous assumption that there was a communication between Lake Superior and the Lake of the Woods. Ashburton and Webster agreed upon a description based upon recent geographical information, but did not consider the line beyond the Rocky Mountains ; and unfortunately the failure to include the northwestern boundary with the northeastern led the two countries to more warlike expressions than had the troublesome boundary on the northeast.

The Massachusetts commissioners accepted the proposition to release the state's claims for the sum named, ${ }^{41}$ and so, finally, did the commissioners from

“The Massachusetts Commissioners to Webster, July 20, I842; ibid., 19. 
Maine, though not without a final protest against the injustice of it. "The commissioners of Maine, invoking the spirit of attachment and patriotic devotion of their state to the Union, would interpose no objection to an adjustment which the general judgment of the nation shall pronounce as honorable and expedient, even if that judgment shall lead to the surrender of a portion of the birthright of the people of their state." 42

The vexed question of the northeastern boundary was thus settled according to the plan which Webster had so long favored. Without the determination of Ashburton that the negotiation should be kept out of formal and written argument his mission would have been a failure, but to Tyler belongs the credit of persuading Ashburton to continue when his tastes and inclinations would have led him to give up in despair. Webster's part was, perhaps, the most difficult of all. That acquiescence on the part of the Maine commissioners was secured was due to his patient and tactful methods.

The northeastern boundary question thus disposed of by compromise, Ashburton and Webster addressed themselves to the task of settling the non-territorial questions in dispute.

The first of these was in reference to the suppression of the slave-trade. The opposition of the United States to conceding to Great Britain any right of visitation or search was too deeprooted to permit discussion, much as Aberdeen desired it. Indeed, the general subject of the right of search was not entered into by Webster and Ashbur-

${ }^{42}$ The Maine Commissioners to Webster; ibid., 19. 
ton. Webster had stated to Cass that any agreement upon the slave-trade must deal with that question alone without drawing into it the ulterior matter of search and visitation. The plan of putting into operation a practicable scheme for the suppression of the trade was Tyler's, who had told Webster that the refusal of France to ratify the quintuple treaty would give greater freedom in dealing with Lord Ashburton. The agreement of 1840 between the American and British commanders for joint cruising in African waters, an agreement which had been disavowed by Van Buren's administration, gave Tyler the idea of a method of policing the slave-trade without introducing the danger of search or visitation. Webster presented the plan to Ashburton, who accepted it, and it formed the eighth article of the treaty. By it each of the parties agreed to keep on the coast of Africa a naval force of not less than eighty guns for the suppression of the trade; each squadron was to be independent of the other, but the government of each was to give such orders as to enable the officers of the respective fleets to act in concert and to coöperate upon mutual consultation as exigencies might arise. Such an agreement was, of course, in the nature of a compromise. Aberdeen was assured of the maintenance of a fleet which would act in concert with a British force. Tyler and Webster held to their position of not conceding a right of search. Had the United States maintained the fleet as agreed, the article might have solved the difficulty. As time went on, the support of the United States waned and the slavers continued to make more and more use of the American flag. The agreement upon the subject was of great importance in its results abroad. France and Great Britain made a similar 
agreement to take the place of the unratified treaty. Wheaton wrote from Berlin that for the first time in our history could it be said that the American government had exerted an influence on the policy of Europe. It was in regard to the eighth article of the Ashburton treaty that this remark was made, and not, as frequently stated, on account of Cass's protest to Guizot.

The Ashburton treaty also contained an important article providing for the extradition of criminals. Not since Jay's treaty had such a provision been inserted in any treaty negotiated by the United States, and the article in that treaty expired by limitation in $\mathrm{I} 806$. By the Ashburton treaty extradition was conceded to either party, the number of crimes increased over those in the Jay treaty, and the time of duration of the article made perpetual.

The question of maritime right (as presented by the Creole) and that of violation of territory (in the case of the Caroline) were not settled by the treaty. Instead Ashburton and Webster exchanged official notes upon these two subjects. In reference to the former, Ashburton pleaded lack of instructions. Webster then asked that Ashburton engage that instructions be given to the colonial authorities in the West Indies which should lead them to regulate their conduct in conformity with the rights of citizens of the United States. To this Ashburton agreed that the laws of the British colonies should be executed with careful attention to the wish of Great Britain to obtain good neighborhood, and that there should be no officious interference with American vessels driven by accident or by violence into West Indian ports. ${ }^{43}$ As to the Caroline affair,

* Ashburton to Webster, August 6, 1842; Webster's Diplomatic and Official Papers, 93. 
Ashburton was reluctant to place himself on record. After a week of conference he agreed to write a letter deprecating the occurrence, finally saying that no affront to the sovereign authority of the United States had been intended. "Looking back at what passed at this distance of time," he wrote, "what is, perhaps, most to be regretted is, that some explanation and apology for this occurrence was not immediately made." "* Webster afterwards said that it took him two days to get Lord Ashburton to consent to use this word "apology." 45

So far the Ashburton mission had been a success. The treaty was signed August 9 and sent to the Senate August II. The committee on foreign relations reported it without amendment, and after debate it was ratified by a vote of thirty-nine to nine, the opponents being Allen of Ohio, Bagby of Alabama, Benton and Linn of Missouri, Buchanan and Sturgeon of Pennsylvania, Conrad of Louisiana, Smith of Connecticut, and Williams of Maine, all Democrats except Conrad.

Much has been written in connection with the Ashburton treaty regarding the so-called "battle of the maps." The subject properly belongs to the discussion of the ratification of the treaty. ${ }^{46}$ It would have been foreign to the spirit of the plan for the adoption of a conventional line had Ashburton and Webster introduced arguments based upon the old maps. Notwithstanding the amount of attention paid these documents during the Senate debates prior to ratification, it may

* Ashburton to Webster, July 28 , I842; ibid., II2.

${ }^{4}$ Curtis's Webster, II., 121, note.

"Foster's Century of American Diplomacy, 284 et seq. 
safely be said that the matter had no place in the negotiation of the treaty. These Senate debates belong rather to the political than to the diplomatic history of the time, and the opposition to the treaty was due largely to the isolation of Tyler and to the anomalous position of Webster. 


\section{CHAP'TER III}

Relations Between Mexico and the United

States Concerning Texas, I825-1840

The Mexican War and the conquest of California formed a distinct episode, completely disassociated from the annexation of Texas. The Mexican War was not caused by the annexation of Texas to the United States. That controlling event in Polk's administration is fully separated from the earlier question of Texas with which Tyler's name is associated. As historical episodes they have no connection, but on the other hand they are rightly viewed as two distinct phases of southwestern expansion. Both were at the expense of Mexico. Both evidenced the expansionist desire of the American nation, a desire which each generation has been able to make effective. The successive accessions to national territory in 1803 , I8I9, 1845 , and 1848 , as well as in 1867 and 1898 , mark the impress upon the national consciousness of each generation's desire for novelty, for adventure, and for new opportunities. No one fact, either economic, or social, or even political, can account for it. Perhaps a national idealism-call it manifest destiny or what you will-has had more to do with this expansion movement than anything else.

In its essentials the expansion of the United States to the southwest is not radically different from its expansion to the west over the Mississippi Valley, to the 
northwest into Oregon, and on across the Pacific to Hawaii and the Philippines. That this southwestern expansion was an'extension of the slave-area does not thereby mark it as different in principle from expansion in other directions. This proposition is not made blindly and without reference to the economic principle that the system of slavery was extensive and not intensive in its methods, and that the perpetuation of slavery required frequent and constant additions to the slavearea. Doubtless this principle of the expansive necessities of slavery has had adequate treatment. It is submitted, however, that instead of slavery's assisting in the expansion of national territory it delayed and almost defeated it. John Quincy Adams, who alone of Monroe's cabinet insisted upon the retention of Texas in I8I9, opposed the annexation of Texas in I845. Between the two dates slavery had grown to be a national question of paramount political importance through the debates upon the right of petition. ${ }^{1}$ Without the introduction of the slavery question opposition to the annexation of Texas would probably never have been the political question which it was in I844. It cannot be maintained that the acquisition of East Florida under Monroe was for the purpose of extending the slave-area, but that charge has frequently been made as to the annexation of Texas and the conquest of New Mexico and California. Viewed superficially, as isolated events in the administrations of two southern and pro-slavery presidents, these steps in southwestern expansion might be considered as territorial

${ }^{1}$ Professor George P. Garrison in the American Historical Review, October, I904. 
additions designed solely to increase the slave-area. If, however, it can be shown that from the time the Florida treaty of I8Ig was ratified there was a series of attempts to win back what had been surrenderedto state it strongly - or to gain for the United States a desirable addition to its territory-to speak more cautiously - then the charge of premeditated expansion by the United States for the purposes of extending slavery falls to the ground. This does not mean that neither Tyler nor Polk was influenced by the fact that southwestern expansion was eminently favorable to the peculiar institution of the South. It would be too much to assert this. Tyler's pro-slavery views added to his annexation enthusiasm in that he feared that if Texas were to abolish slavery it would endanger the slave institutions of all the southern states. In considering the question of the annexation of Texas, New Mexico, and California, therefore, it will be necessary to keep in mind that the first step in that direction was not the negotiation for the annexation of Texas under Tyler, but the series of abortive attempts at southwestern extension which began early in the administration of John Quincy Adams. Adams, two years before when secretary of state under Monroe, had offered the position of minister to Mexico to Andrew Jackson without previously sounding Jackson as to whether or not he would accept. The appointment was declined in terms not wholly gracious." After Ninian Edwards had been appointed and had resigned,

${ }^{2}$ Jackson to Adams, March 15, I823; MS., Archives, Department of State. In subsequent notes these manuscripts will be referred to as "MS., Archives." 
Monroe's term ended. Not until the administration of Adams were diplomatic relations between the United States and Mexico really established.

The first instructions issued by Henry Clay, as secretary of state under Adams, to Joel R. Poinsett, minister to the United Mexican States, dated March 25, I825, discussed the advisability of extending the southwestern boundary so as to include Texas. After declaring that the principles upon which the American policy toward Mexico was based were those set forth in Monroe's famous message of December 2, 1823, Clay proceeded to the matter of boundaries between Mexico and the United States. "Some difficulties," Clay said, "may hereafter arise between the two countries from the line [of I8I9] against which it would be desirable now to guard if practicable; and, as the government of Mexico may be supposed not to have any disinclination to the fixation of a new line, . . . the President wishes you to sound it on that subject, or to avail yourself of a favorable disposition, if you should find it, to effect that object. The line of the Sabine approaches our great western mart nearer than could be wished. Perhaps the Mexican government may not be unwilling to establish that of the Rio Brassos de Dios, or the Rio Colorado, or the Snow Mountains, or the Rio del Norte in lieu of it." ${ }^{3}$ This was intended to be a mere rectification of the frontier line without any further consideration to be paid for the cession of territory than that the United States and not Mexico would be forced to take care of the warlike Indian tribes infesting the plains of Texas. At

${ }^{3}$ Clay to Poinsett, March 25, I825; MS., Archives. 
that early date, however, Mexico was suspicious of the United States. Poinsett protested against any treaty that Mexico might make with any other Spanish-American state in which more favorable terms were given than might be granted to the United States. He then proposed to the Mexican government that a new treaty of limits be entered into, laying aside altogether the treaty of I8I9.

Thus at the outset of our relations with Mexico grave suspicions were aroused as to the intentions of Mexico's growing and powerful neighbor on the north. "It is manifest," Poinsett reported July 22, I825, "that the [Mexican] government regards all our movements towards Texas and New Mexico with jealous apprehension." " "I find that there exists great apprehension in the minds of the people of this country that the government of the United States contemplates renewing their claim to the territory north of the Rio Bravo del Norte, and it may be of some importance to consider their great sensibilities on this subject. It appears to me that it will be important to gain time if we wish to extend our territory beyond the boundary agreed upon by the treaty of I8I9. Most of the good land from the Colorado to the Sabine has been granted by the state of Texas and is rapidly peopling with either grantees or squatters from the United States, a population they will find difficult to govern, and perhaps after a short period they may not be so averse to part with that portion of their territory as they are at present." :

Poinsett did not persist in the advocacy of a policy

- Poinsett to Clay, July 24, I825; MS., Archives.

'Poinsett to Clay, in cipher, July 27, 1825; MS., Archives. 
of delay toward Mexico. He reported that he was very anxious about the boundary line and that, while he thought it politic not to justify the jealous fears of Mexico by extravagant pretensions as to Texas, he felt it of the highest importance that the United States should extend its territory toward the Del Norte, either to the Colorado, or at least to the Brazos.

The negotiation that followed hinged upon the question as to whether the treaty of I8I9 should be adopted as to boundary or a new treaty entered into. For two years the matter never went beyond the stage of preliminary discussion. During all this time Texas was being colonized by settlers from the southern part of the United States. Clay adopted the idea expressed in Poinsett's early letter, that Mexico would be less loath to part with Texas when it was seen that that country was being peopled with settlers of a different race, speaking a different language and importing strange institutions-a mistaken judgment as the sequel showed. Clay's instructions proceeded upon that theory. Instead of depending upon mere argument as to the desirability to both parties of a new boundary line, Poinsett was authorized to pay a million dollars for a line from the Del Norte to the forty-second parallel and thence west to the Pacific. If this cession was found to be impossible, he was authorized to offer half that sum for a line beginning at the Colorado, thence north and west as before. Any treaty so negotiated might confirm all land grants made prior to its execution and also include a stipulation similar to the

- Poinsett to Clay, August 5, 1825; MS., Archives. 
one in the Louisiana treaty providing for the incorporation of the inhabitants of the ceded lands into the Union." Poinsett reported that he feared the sum authorized was much too small. "The expenses of the government are so great that they do not regard so insignificant a sum as a million as of much use to them." 8 No effort was made to communicate Clay's offer to Mexico, as Poinsett believed the overture would have no other effect than to aggravate the irritation between the two countries. ${ }^{\circ}$ Feeling that any attempt to alter the former treaty of limits (that with Spain in I8I9) would prove ineffective and only provocative of unfriendly feelings, he thereupon accepted the proposal of the Mexican government and renewed, the old treaty of $1819 .^{10}$ This treaty adopted the boundary line as set forth in the Spanish treaty, and for the second time Texas was left outside of the boundaries of the United States.

Such was the state of the relations between the United States and Mexico when Jackson succeeded to the presidency. He found a treaty signed but not ratified which left the Sabine as the western boundary. Haste was not to be expected of the Mexican government, and Jackson's administration made no effort to hurry ratification. Van Bure instructed Poinsett, epon much the same grat is those taken by Clay, $J$ open a negotiation for : Jurchase of Texas or

${ }^{7}$ Clay to Poinsett, March Quincy Adams, Memoirs, Vl

${ }^{8}$ Poinsett to Clay, May io i, 27 ; MS., Archives.

- Niles' Register, LXVI., - 52.

${ }^{10}$ Poinsett to Clay, January 8, I828; MS., Archives.

$$
\text { , MS., Archives. }
$$

1827 ; MS., Archives; Jo'... 239, 240; Von Holst, II., 554. 
for as much of it as he could get. ${ }^{11}$ It is at this point that Von Holst perceives a decided change in the attitude of the United States toward Texas and Mexico. With the accession of Jackson he sees the first play in the conspiracy of the slaveholding South to extend slave territory. Just how Van Buren's instructions to Poinsett differ from Clay's is not clear, except that the amount to be offered is increased from one million to five-a necessary increase, as Poinsett had pointed out.

${ }^{11}$ Van Buren to Poinsett, August 25, I829; S. Ex. Doc. 351, 25 Cong., 2 Sess., 315. MS., Archives, Volume I., number 30. These instructions were drafted by Jackson as follows:

\section{"August I3th, I829-}

"The inducements to be presented to the Mexican government for the cession of Texas to the United States.

"Ist. The advantage of having a Natural boundary over the one which is now imaginary and unsettled.

" 2 d. The aid which the consideration she will receive for it, will give her in repelling such attempts upon her Sovereignety as that recently organized at Havanna; in providing a Navy, and the means of vigorous defence.

" 3 d. The removal of those collisions which must grow out of the intercourse of her citizens with ours, seperated as they will be from the efficient control of their respective governments: and liable to all the excitements natural to the neighbourhood of conflicting laws, habits and interests.

"4th. Its real necessity to us as a guard for our western border and the proter "nn" of New orleans-furnishing a motive for the cession : 'ich '1 be honorable to the repul lican character of Mexir it worthy of that reciproc $\rightarrow$ irit of friendship which vald forever characterise th eelings of the two governn toward each other.

" 5 th. The Probability 0 : being settled chiefly by the citizens of the United State ho under a different system of Govt. may become tur lent and dificult of Controul, and taking advantage of heir distance from Mexican authority might endeavour to esta dish one independant of it- 
During all the years of Poinsett's residence in Mexico as minister a stream of colonists from the United States had gone into Texas. Most of them, it is true, were southerners and slaveholders. Some of them were from the North, even from Connecticut and New York. The only differences in the situation of 1829 from that of 1825 were that more Americans were in Texas, more lands had been taken up, speculations in lands had been begun, and public attention had been directed thither.

an event that will be sure to make this Govt. the object of Jealousy, and in conjunction with other causes unavoidable on an imaginary line of boundary of manny hundred of miles might seriously weaken those bonds of amity and good understanding which it is the interest and duty of both Republics to cherish.

"Objects of the United States in obtaining it.

"Ist. The safety of New Orleans. The present boundary would enable an enemy of the Sabine, Red \& Arkansas rivers, to organise a force which by a coup de man might reach the Mississippi and thereby prevent the interposition of one by us sufficient for its protection. This disadvantage can only be overcome by having within our possession all the Territory washed by the branches of the Mississippi.

"2d. The acquisition of additional territory for the purpose of concentrating the Indians, adopting a more effective system for their Government, and relieving the states of the inconveniences which the residence within their limits at present afford.

" 3 d. The procurement of a natural boundery-one that cannot become the subject of dispute hereafter, and near to which a dense population on either side can never be settled.

"These purposes will be accomplished by obtaining a cession to the Grand Prairie or desert west of the Nucees, beginning at the Gulf, and following the courses of the centre of that desert, North to its termination on the mountain, thence with a central line on the mountain, dividing the waters of the Rio del Nort from those that run Eastward of them in the Gulf, to the 42d. degree of North latitude until it 
Before Poinsett had really opened the question he was recalled. Jackson's and Van Buren's ideas as to a suitable boundary are to be gained from Poinsett's last instructions: he was authorized to offer five millions for a line beginning in the centre of the desert between the Del Norte and the Nueces, north to the forty-second parallel and west to the Pacific, but for proportionately less sums. If the first line was impossible, he was to try to fix the boundary at Matagorda Bay or even at the Brazos.

strikes our present boundery on that parallel. This line is a natural seperation of the resources of the two nations. It is the centre of a country uninhabitable on the Gulf, and on the mountain so difficult of access and so poor as to furnish no inducement for a land intercourse, and of course no theatre for those causes of difference that belong to a neighbourhood of commercial interests. An advantage which would be lost if we were to stop short of it, either at the Brassos or the Trinity. Beyond either of these rivers and this line on the Gulf is a section of fine land.

"For these reasons I wish Mr. Poinsett to be instructed to open a Negotiation for the purchase of this Territory, and be authorised to offer as high as five millions subject to the conditions mentioned in my former note.

"Andrew Jackson.

"Note-The condition alluded is, that he shall consider five Million as the Maximum, and in the event of success to obtain first the ratification of their constituted authorities, before it is submitted for ratification to this Govt.and to get it as low as possible-and if the limits cannot be obtained-To obtain to the Brassos or to the Trinity agreably to the ratio of the Maximum stated-and if Cash should be preferred to payment by instalments (and cash I suppose would be a great inducement,) let cash be stipulated to be paid after ratification by our government, as we can in a few days raise it by creating stock.

MS., Jackson Papers, Library of Congress.

“A. J." 
These instructions from Jackson were sent to Poinsett by one Colonel Anthony Butler, an old comrade in arms of Jackson. Butler lacked moral character and fitness for any position of trust. No worse selection for a diplomatic position could have been made. Poinsett, who had been extremely cautious about making overtures for the cession of Texas, fearing to arouse the jealous and suspicious national character of Mexico, which was continually harassed by internal dissensions, was recalled to make room for Butler, who was charged with being a speculator in Texas lands, a gambler, a drunkard, and a liar. But this last epithet came from Jackson himself some years afterwards, when his shortness of memory afforded him an easy escape from the entanglements of fact. It is safe to say that Butler's mission, discreditable and even disgraceful, had much to do with the unsatisfactory course of our diplomatic relations with Mexico which ended in war.

When Butler appears for the first time upon the stage of diplomacy, he had recently been in Texas and professed to be familiar with the proposed river boundaries. Sent to Mexico as a bearer of despatches to Poinsett, he went overland, again through Texas, and secretly. Upon this mission he was given authority to confer with the Mexican officials upon the subject of limits. Upon Poinsett's recall, he was made chargé. $^{12}$ From 1829 to 1836 , during practically all of

${ }^{12}$ Jackson's reasons for recalling Poinsett were as follows: "From the best consideration I have been able to give to this subject, I have come to the following result.

"Mr. Poinsett's situation at Mexico must be very unpleasant \& mortifying-The secretary of Foreign relations his enemy 
Jackson's term, Anthony Butler represented, or rather misrepresented, the United States in Mexico. It was a seven years' period of cheap trickery in which, on the one hand, Mexico was led to believe that the United States government would descend to any level to accomplish the cession of Texas, and on the other, Jackson was encouraged by hopes of a cession which came to nothing.

In the spring of 1843 John Quincy Adams, then a member of the lower house, spent many hours in going over the correspondence of Butler. His mission,

and at the head of the strong minority who he wields to his purposes \& in hostility to Mr. P. by which he overaws the Executive of Mexico who is friendly to our Government, \& to our Minister-under these circumstances we cannot reasonably to expect through Mr. Poinsett to effect either, a commercial Treaty, or the Settlement of our limits, or cession of Territory in Texas. In proof of this we find, that the President failed, (after being requested by Mr. Poinsett) to notify the Congress when he convened them that one object would be to ratify the commercial treaty that had been returned by this Government, and not being thus notified, the Congress could not act on it-This to my mind is sufficient proof that the executive of Mexico is overawed by the Minority with the Secretary of Foreign relations at their headTherefore let Mr. Poinsett with his secretary be invited home, (recalled) in such a way as will preserve his feelings and give no cause for exultation by this Minority or his enemies. In a firm but decorous language, breathing the best feelings to the Mexican Government, But observing that this government cannot but be alive to the insult offered to our government by the insult intended by the public act of the Legislature of one of the States of Mexico, by their resolution passed by that body calling upon their Chief Executive to banish from Mexico our Minister, without making to this government any representation of his improperly interfering with the interior concerns of their government, as well as the deep rooted Jealousy \& hostility expressed in their public acts published to the World against our Government,- 
Adams records in his diary, was "chiefly to obtain the cession of Texas." "13 Butler's instructions were those sent by Van Buren to Poinsett during the previous summer. "The three-fold and double-dealing line of negotiations: I-for a commercial treaty; 2-indemnity for all sorts of claims, and 3-to strip Mexico of Texas, Santa Fe and California, runs into the most curious details of Jackson and Tyler duplicity." ${ }^{14}$ Such was Adams's judgment after a careful review of Butler's correspondence. It became evident that Mexico would enter into no new treaty of limits, nor would she, indeed, ratify the treaty signed by Poinsett in which the line of I8I9 was adopted, until the United States was willing to enter into a conmercial treaty. In this Butler acquiesced, and a commercial treaty upon a favored-nation basis was signed in April, I831. Jackson was informed that the question of Texas would be opened at once. Butler did nothing for a

whilst all the acts of ours, displayed the most sincere friendship \& good will to thiers, \& our instructions to our Minister was to give every assurance of our friendship \& good will for the republics of the South, and particularly MexicoBut to preserve our Minister from those continued insults of the Minority \& to foster, \& continue our friendship a good understanding with the Republic of Mexico, we have withdrawn our Minister \& his secretary, \& has charged Col Butler to represent our Government at Mexico, as charge de affairs with full powers to carry into effect any commercial regulations, and the settlement of our boundary \&c \&c \&c and to cultivate the most friendly relations with that Government-With the assurance that whenever Mexico, thinks proper to send a Minister we will receive \&c \&c "Andrew Jackson"

MS., Jackson Papers, Library of Congress.

${ }^{13}$ John Quincy Adams, Memoirs, XI., 343.

${ }^{14}$ Ibid. 
year thereafter further than to keep up the hopes of the administration, yet excusing himself for the delay by doubts expressed as to the sincerity of Alaman, the Mexican minister of foreign relations. ${ }^{15}$

In July, I832, Butler had a conference with Alaman in which he urged the cession of Texas to the United States because he believed that at no distant time such a serious revolt would occur there that the Mexican government would not be able to suppress it. "The revoit once commenced," he said, "Texas is lost to Mexico forever; upon this subject my government feels the greatest anxiety." ${ }^{10}$ This expression of remarkable prescience on Butler's part failed in its effect. Instead of filling Alaman's mind with fears for the future of Texas, the Mexican secretary replied with a query as to the territorial desires of the United States. These Butler gave him, and the conference ended. Its significance was this: "Unless you sell Texas to us, Texas will soon be independent, and she will be lost to Mexico in any event."

Butler's direct avowal to Alaman of his desire for Texas gave way to a plan by which the United States should make a loan to Mexico with Texas as security. Jackson was appealed to by his chargé for definite instructions upon this plan: ${ }^{17}$ Butler's letter was referred by Jackson to Livingston with the following

${ }^{15}$ Butler to Jackson, May 25, I83I; MS., Archives; John Quincy Adams, Memoirs, XI., 362.

${ }^{16}$ Butler to Livingston, July 16,1832 (received October 5, I832), MS., Archives. Writing to Jackson, August I2, I832, Butler despaired of accomplishing his purpose. MS., Jackson Papers, Library of Congress.

${ }^{17}$ Butler to Jackson, February 10, I833; MS., Archives. 
endorsement: “The president, with his respects to $E$. Livingston, Esq., Sec. of State, encloses a letter just received from Col. A. Butler with a request that he prepare a reply, consistent with the endorsement made on the letter, adding anything that your own judgt. may suggest on this subject. Instruct Col. Butler to bring the negotiations to a close. The Convention in Texas meets the Ist of next April to form a constitution for themselves. When this is done, Mexico can never annex it to her jurisdiction again, or control its legislature. It will be useless after this act to enter into a treaty of boundary with Mexico." ${ }^{18}$

Jackson's forecast of the time of the Texas constitutional convention was correct although it was not remarkable, as this date had been publicly announced. As to the results of the work of the convention, however, his enthusiasm outran his judgment. The constitution which the convention adopted, while republican in form, was in no sense a declaration of independence. It was put forth in the attempt to make Texas a self-governing member of the Mexican confederation. While the convention deliberated, Santa Anna, who had overthrown Bustamente in the government of Mexico, was entrenching himself in power. Austin, one of the bearers of the Texan constitution to Mexico, was imprisoned. The spirit of rebellion, long suppressed, broke into one of independence. "Like the American Revolution, that in Texas was well under way before the colonists were willing to take

${ }^{18}$ Jackson's endorsement, dated March 15, 1833, MS., Archives. September 26, I833, Butler advised Jackson to take possession of Texas, as he saw no hope of negotiation. MS., Jackson Papers, Library of Congress. 
the decisive steps of declaring themselves independent. The revolution passes, therefore, through two main phases: at first it was a struggle for the constitutional principles on which the Mexican Federal Republic had been organized [the Constitution of 1824]; and when this failed because of the complete triumph of Santa Anna in the Mexican states up to the Rio Grande, it became necessarily a struggle for independence." 19

The treaty of limits negotiated by Poinsett in 1828 and ratified in 1832 provided for commissioners to mark the boundary of 1819 . The time for the appointment of these had expired, and Butler now signed an additional article extending the time for the performance of the treaty. ${ }^{20}$ This he brought to Washington in June, I835. While there he made an extended report to Forsyth in which he outlined a new plan for the acquisition of Texas through the bribery of Hernandez, a priest in Santa Anna's household, "known," he affirmed, "to be the manager of all the recent negotiations of the Palace." Butler stated that if his plan were adopted, the treaty which would give us Texas "would only be the first of a series which must at last give us dominion over the whole of that tract of territory known as New Mexico, and the higher and lower California, an empire in itself, a paradise in climate . . . rich in minerals and affording a water route to the Pacific through the Arkansas and Colorado rivers." ${ }^{21}$ Butler elaborated at length upon

${ }^{10}$ Garrison's Texas, I89.

${ }^{20}$ Butler to Forsyth, June 9, $1835 ; H$. Ex. Doc. 256, 24 Cong., I Sess., 5.

${ }^{21}$ Butler to Forsyth, June 17, I835; MS., Archives. 
the grandeur of his country's destiny, to be achieved so easily. His argument was backed by alleged copies of his correspondence with Hernandez. Santa Anna's agent was asked to state definitely what would accomplish the transfer of Texas. Upon the assumption that five millions would be the consideration, Hernandez replied: "Five hundred thousand judiciously applied will conclude the affair, and when you think proper to authorize me to enter into the arrangement, depend on my closing it to your satisfaction." ${ }^{22}$

Upon the back of this report is the following endorsement in Jackson's own hand: "Mexico-TexasNothing will be countenanced by the executive to bring the government under the remotest imputation of being engaged in corruption or bribery. We have no concern in the application of the consideration to be given. The public functionary of Mexico may apply it as they deem proper to extinguish private claims and give us the cession clear of all incumberence [sic] except the grants which have been complyed with. A. J. June $22-35$."

Butler should have been dismissed from the service at once. Five years had been wasted in attempts to win over Mexico to a decision to sell Texas, and the only fruit of Butler's negotiations was a cheap and low plan of bribery with a priest as a go-between. It was the beginning of the strange infatuation which the government of the United States had, that through Santa Anna's greed and military necessities Mexi-

${ }^{22}$ Hernandez to Butler, March 21, 1835. Copy enclosed in Butler's letter to Forsyth, as above.

${ }^{23}$ Endorsement of Jackson upon Butler's letter as above. 
can territory might be purchased, an infatuation which lasted well through the Mexican War. In 1843 , when Butler had been charged by the Whigs with having attempted to use dishonest methods toward Mexico, he appealed to Jackson to vindicate him. In his letter he claimed that Jackson had sanctioned and then angrily denounced the proposed bribery, and afterwards in conversation had signified his willingness, provided the affair was managed without his own cognizance. ${ }^{24}$ Jackson replied to Butler that he was a scamp and a liar. As to what took place in the interview is a question of fact between Jackson and Butler. Jackson's own words, however, do not convey the impression that he disapproved of Butler's plan, except so far as bribery was connected with it. Instead of dismissing the chargé, he was sent back to Mexico to renew his efforts for the cession of Texas. Adams, upon examining Butler's correspondence, wrote that the letter of June I7, I835 (in which the bribery method was suggested), was the passe-partout of the whole system pursued with inflexible perseverance down to the time of Tyler. But even Jackson at last became convinced of Butler's worthlessness, and he was finally recalled after he had been instructed to press for a cession of Texas and California as far north as San Francisco. Jackson was anxious that if Butler succeeded it should be before Congress met in December, I835. Following a long silence on the part of the chargé, he was removed and Powhatan Ellis of Mississippi appointed.

${ }^{24}$ Cf. Dr. James Schouler in the Atlantic Monthly, February, I905, 220. 
At this point the course of the relations with Mexico takes a decided turn. Nothing further is heard of the proposal to buy Texas, for the events which Jackson had prematurely foretold in 1833 were at last at hand. Instead there was assumed a bold and determined position upon the subject of the claims of sundry American citizens upon Mexico. That these were many and aggravated there is no doubt. That in every case Mexico had delayed or refused settlement is equally true. But the moment at which Mexico was hard pressed in its effort to put down the Texan war for independence was chosen by Jackson to push the claims: Ellis was given a memorandum of these and directed to press for immediate settlement. In July, I836, he was told that unless he received satisfactory assurances from Mexico within a fortnight thereafter that the claims would be adjusted, he should demand his passports. ${ }^{25}$ Ellis did as instructed, but not until the following December. No satisfactory answer having then been received from Mexico, he broke off relations with that government and returned home. ${ }^{28}$ For three years thereafter the United States had no minister at the City of Mexico.

During Ellis's unsatisfactory effort the question of the recognition of Texan belligerency and independence arose. Toward it Jackson was as timid as he had been bold in pushing the collection of the claims. Early in November, I835, Forsyth outlined to Castillo,

${ }^{25}$ Forsyth to Ellis, July 30, 1836; H. Ex. Doc. 105, 24 Cong., 2 Sess., 20.

${ }^{26}$ Jackson's message, February 6, 1837; Richardson's Messages, III., 278; S. Ex. Doc. 160; H. Ex. Doc. 139, 24 Cong., 2 Sess. 
the Mexican minister at Washington, the policy of the administration toward the contest in Texas as one of strict neutrality; the Mexican government was informed that "the President looked with regret upon the existing state of affairs in Texas, and that in the probable event of a protracted war in Texas itself, neither party could be permitted to encroach upon the territorial limits of the United States." ${ }^{27}$ At the time this note was sent the Texans had little chance of immediate success in achieving their independence. Diplomatically hesitating to call a spade a spade, Forsyth referred to the "existing state of things" as a "contest" which might ultimately be protracted into a war. The victory of the Texans over the Mexican army at San Jacinto and the capture of Santa Anna gave a very different status to what Forsyth had called "the state of things." On March 2, I836, Texas formally declared its independence, and a fortnight later a constitution was drawn up and a government organized. Two days after the signing of the Texan declaration of independence, commissioners were sent to Washington, and they left Texas before the battle of San Jacinto. The news of the victory reached Washington at about the same time as did the Texan commissioners, George C. Childress and Robert Hamilton. They were welcomed as fellow-citizens rather than as envoys from a revolutionary government. The commissioners at once asked for recognition and for relations with the United States of the most friendly character. Favorable to the Texan cause as Jackson was known

${ }^{27}$ Forsyth to Butler, November 9, I835; H. Ex. Doc. 256, 24 Cong., I Sess., 3 
to be, he was very cautious about the reception, and the consequent recognition, of Childress and Hamilton. The Senate held that under the federal constitution there were four ways of recognizing a power as independent: ( I) by treaty; (2) by the passage of a law regulating commercial intercourse; (3) by sending a diplomatic agent, properly accredited, to the new power; and (4) by the reception by the President of a diplomatic agent from the new power. ${ }^{28}$ Jackson cautiously threw the responsibility of recognition upon Congress, awhich took no action until December, 1836. When

- Congress met it was informed that the President was forced to pause in expressing the opinion that Texas was capable of performing the obligations of an independent nation. "Foreign policy, the conventional faith of nations, or the efforts of Mexico, might detain Texas lingering in her embryo state for many years," so Jackson's confidential agent in Texas, Henry M. Morfit, had reported. The glowing accounts that Jackson must have hoped for were lacking. Jackson informed Congress that "prudence seemed to dictaie that we stand aloof and maintain our present attitude," if not until Mexico itself or one of the great foreign powers should recognize the independence of the new government, at least until the lapse of time or the course of events should have proved "the ability of Texas to maintain its separate sovereignty." ${ }^{20}$ Con-

${ }^{28}$ Clay's Report as Chairman of the Committee on Foreign Relations of the Senate, June 18, 1836; Senate Report 406, 24 Cong., I Sess.

${ }^{20}$ Jackson's message, December 21, 1836; Richardson's Messages, III., 265. Extracts from Morfit's report upon Texas accompanied the message. 
gress, however, was unwilling to delay the matter. An item in the appropriation bill providing for the salary of a chargé to Texas was passed on the last day of Jackson's term. Jackson's last official act was the appointment of Alcée La Branche of Louisiana as chargé to Texas. ${ }^{30}$ Soon afterward the Texan commissioner in Washington was received by Van Buren and the recognition of Texan independence was complete.

From the Mexican legation at Washington came a series of complaints that the United States had violated its professed neutrality in permitting troops to be raised for Texan service and in authorizing General Gaines's forces not only to assemble on the line between Louisiana and Texas but also to encroach upon Texan territory by crossing the Sabine. ${ }^{31}$ In October, I836, Gorostiza, the Mexican minister, presented a pamphlet reviewing the causes of his protests, and demanded his passports. "Mexico," he said, "has but little to expect from the United States, seeing that its most sacred rights, as well as its dearest and most positive interests, are now being sacrificed to the shadow of a danger hitherto imaginary. Mexico is outraged and ruined from motives of mere precaution. ( $\mathrm{Se}$ injuria á Mexico y se le daña por mera precaucion.)" He therefore declared his mission at an end. ${ }^{32}$ Thus diplomatic relations between the United States and Mexico were suspended, in Mexico by Ellis's uncom-

${ }^{30}$ Jackson's message, March 3, I837; ibid., III., 281.

${ }^{31}$ H. Ex. Docs. 256, 24 Cong., I Sess., and I90, 25 Cong., 2 Sess.

${ }^{32}$ Gorostiza to Dickins, October 15, I836; H. Ex. Doc. I9o, 25 Cong., 2 Sess. 
promising position upon the subject of American claims, and at Washington by Gorostiza's protests against violations of nettrality by the United States. The United States was thus led to adopt a policy in reference to Texan annexation the reverse of its course since $1825 .{ }^{33}$ It was one thing to scheme for the annexation of Texas while that province was admittedly a part of Mexico. It was quite another to annex a province in rebellion, thereby precipitating a war with Mexico.

It is impossible to say how much the fear of war with Mexico cooled Jackson's ardor for annexation. Certainly the force of it cannot be overlooked. ${ }^{34}$ Nor on the other hand must one neglect the important bearing of the slavery question upon the subject. As has been said, expansion to the southwest was hindered by the question of slavery, which was commingled with it.

The battle of San Jacinto resulted in the capture of Santa Anna, who while in captivity agreed that the war against Texas should cease, that the Mexican troops should retire beyond the Rio Grande, and that he would favor the recognition of Texas. In pursuance of this agreement the Mexican army was withdrawn, but the Mexican government gave notice that any agreement with Texas made by Santa Anna while a prisoner was null and void. Santa Anna's appeal to Jackson for aid in ending the contest between Mexico and Texas had the appearance of honesty, ${ }^{35}$ but

${ }^{33}$ Von Holst, II., 573-85: "A more shameless comedy of neutrality was never played."

${ }^{34} \mathrm{Cf}$. Garrison in American Historical Review, October, 1904, 81.

${ }^{35}$ Santa Anna to Jackson, July 4, I836; Richardson's Messages, III., 274. 
Jackson declined to consider it on account of Mexico's repudiation of Santa Anna's act. "Good faith to Mexico," he said, "makes it impossible for me to take such a step." ${ }^{36}$ At the time Jackson's reply was sent, the Texan commissioners were in Washington vainly attempting to hasten recognition.

With recognition was inseparably bound annexation to the United States. While the first was delayed, the people of Texas voted almost unanimously for annexation. ${ }^{87}$ The Texan commissioners reported that Jackson was undoubtedly in favor of annexation and that his administration would carry the measure through. ${ }^{\text {ss }}$ Jackson's refusal to take the initiative as to recognition was a wet blanket to the hopes of the commissioners. They did not expect so "cold-blooded a policy from him." From Texas the commissioners received urgent instructions to push annexation. The terms of the measure were relatively unimportant, if the result could be accomplished. Henderson, the Texan secretary of state, wrote to Memucan Hunt, who had been appointed minister from Texas in December, I836,

36 Jackson to Santa Anna, September 4, I836; ibid., 275; Bancroft's Texas, II., 268 sqq; Yoakum, Texas, II., I54 sqq. Santa Anna in his autobiography ("Mi Historia Militar $y$ Politica, I810-I874" Mexico, I905, page 4I) gives an account of his reception by Jackson in November, 1836, at Washington: "El Presidente Jackson manifestó vivo empeño por el término de la guerra. Repetia: 'México reconociendo la independencia de Texas será indemnizado con seis millones de pesos.' Yo le contestaba: al Congreso mexicano pertenece únicamente decidir esa cuestion."

${ }^{37}$ There were 3277 for and 91 against. Garrison, in article cited, 74 .

${ }^{88}$ Collingsworth and Grayson to Burnet, July I6, I836; Catlett to Austin, January II, I837; quoted by Garrison. 
suggesting that annexation be effected by act of Congress instead of by treaty in case he should find that a treaty of annexation might lack the necessary vote in the Senate upon the ratification. This is doubtless the first suggestion of the method of annexation by joint resolution that was afterwards adopted when the Senate rejected Calhoun's treaty in June, I844. ${ }^{39}$ Hunt, however, who had to wait for recognition, was forced to remain silent upon the ulterior question of annexation, and when Jackson went out of office the annexation of Texas appeared to be indefinitely postponed.

With the accession of Van Buren began the play of diplomacy that continued until annexation was finally effected. This was to force the question of annexation forward by arousing in the United States the fear that Great Britain, by recognition of, or by commercial treaties and even alliance with, Texas, would control the destinies of the Lone Star Republic. In the instructions in which annexation by joint resolution was suggested to Hunt, Henderson stated that "in the event of [a refusal of] that government to receive [Texas] . . . into the Union, either as a State or as a Territory, it may become necessary for Texas to form a Treaty of Amity and Commerce with England or some other European power which would forever and entirely preclude the people of the United States from enjoying any of the benefits resulting to Texas." " The negotiation of a commercial treaty

" Garrison, in article cited, 78.

${ }^{40}$ Henderson to Hunt, December 3I, I836. Quoted by Garrison, ibid., 78. 
with Great Britain, however, depended necessarily upon recognition, and that did not occur until I839, during the presidency of Lamar, who was opposed to annexation to the United States.

In August, 1837, the well-known anxiety of the Texan people for annexation was officially expressed by Hunt, who, after reviewing the history of Texas and the desirability to both the United States and itself of its incorporation into the American Union, urged the immediate discussion and negotiation of a treaty of annexation." Forsyth answered Hunt's letter promptly and reminded him that the questions of recognition and of annexation were quite distinct. As to recognition, the United States decided upon the question of fact, and not upon right. Annexation, however, proceeded upon a different theory. "The question of the annexation of a foreign independent State to the United States had never before been presented to the government. . . . Whether the constitution of the United States contemplated the annexation of such [an independent] State and if so, in what manner that object is to be effected, are questions in the opinion of the President, it would be inexpedient, under existing circumstances, to agitate. So long as Texas shall remain at war, while the United States are at peace with her adversary, the proposition of the Texan minister plenipotentiary necessarily involves the question of war with that adversary. The United States are bound to Mexico by a treaty of amity and commerce, which will be scrupulously observed on

"Hunt to Forsyth, August 4, I837; H. Ex. Doc. 40, 25 Cong., I Sess., 9. 
their part, so long as it can be reasonably hoped that Mexico will perform her duties and respect our rights under it." ${ }^{23}$

Thus Forsyth not only refused Hunt's proposal for annexation, but he declined holding out hopes of any reversal of this decision. "The United States might justly be suspected of a disregard of the friendly purposes of the compact, if the overture of General Hunt were to be even reserved for future consideration. - . . The inducements . . . [for annexation] powerful and mighty as certainly they are, are light when opposed in the scale of reason to treaty obligations and respect for that integrity of character by which the United States have sought to distinguish themselves." \&s

There could be no mistake as to the meaning of Forsyth's reply; it was a definite and final refusal of Texan annexation, based upon the duties of the United States toward Mexico. Anson Jones, who succeeded Hunt as minister to the United States the next year, was instructed formally to withdraw the offer of annexation. Lamar, an active opponent of annexation, became president of Texas in 1838 , and the Texan Congress ratified the withdrawal of the annexation proposition."

In Von Holst's history is elaborated an argument to show that it, was Jackson's policy, followed by Van Buren, to provoke a war with Mexico upon the subject of the claims, and as a result of this war to annex

2 Forsyth to Hunt, August 25; I837; ibid., I2.

"s Ibid., I3.

"Garrison, in article cited, 96. 
Texas. This idea had its origin with John Quincy Adams, who gave utterance to it in his long speech delivered in the House during the summer of 1838 . Von Holst called Jackson's attempt to press the payment of the claims an "unworthy hypocritical comedy," ${ }^{45}$ as he had characterized the administration's neutrality policy as a "shameless comedy." " words are obviously unfair. Considering the public sentiment in favor of the South American revolutions of twenty years before and that shown during the recent Cuban insurrection, Jackson's attitude toward the Texan revolution appears to good advantage, for which he deserves the more credit because his own sympathies and those of a great portion of the American people were with the Texans. When one considers the speed with which the United States recognized the Republic of Panama, Jackson's position becomes not only creditable but commendable. He cannot be blamed for refusing to risk a war with Mexico. This is rather to his credit. If his plan had been to push Mexico into war on account of the claims, there was nothing to hinder him from carrying it into execution. Policies are like the men who create them: they are neither wholly good nor wholly bad. Jackson's and Van Buren's attitude toward Texan annexation was cautious, prudent, and founded upon just principles. That the tone adopted toward Mexico upon the subject of claims was severe does not thereby convict Jackson and Van Buren of duplicity, or of hypocrisy, or of shamelessness. It was hardly different from the one Jackson adopted toward France upon the sub-

${ }^{4}$ Von Holst, II., 597.

${ }^{46}$ Ibid., II., 583. 
ject of claims. For that no criticism was made. That many of the claims urged against Mexico were exorbitant and some of them fraudulent does not change the case. Some of the claims were just and of long standing. It is as much the fault of the historian to underestimate their importance as it was the fault of the administration to overestimate them. To any one who has the slightest knowledge of Spanish-American character it is well known that the traditional policy of the Spanish-American states is to delay the admission of any claims, and when, at last, a claim is admitted, to procrastinate in payment as long as patience will permit. Instead of using the Mexican claims as a cloak for war by which annexation might be accomplished, the reverse may be stated as the truth. The open refusal of the United States to accept the Texan offer of annexation put the United States in a position where demand for payment of its claims upon Mexico could be made without any suspicion of ulterior motive.

Ellis had demanded his passports in 1836 and Gorostiza left Washington soon after. ${ }^{47}$ Mexico then made an overture to the United States for the reopening of diplomatic relations, and sent a minister, Martinez, to Washington who was instructed to enter into a treaty arrangement for the reference of the claims to arbitration. Mexico's advance was met by the United States. Forsyth and Martinez agreed to arbitrate the claims in a treaty concluded in the spring of 1839. Jackson's policy was justified by its result.

${ }^{4}$ Robert Greenhow was appointed bearer of despatches in May, 1837. Martinez was in Washington, August I3, I838.

"Treaties and Conventions between the United States and Foreign Powvers, 676; H. Ex. Doc. 252, 25 Cong., 3 Sess. 
The term of Ellis as minister from the United States to Mexico covered the administration of Van Buren and a part of that of Tyler, when he was replaced by Waddy Thompson of South Carolina. Ellis's instructions were to continue to observe the neutral policy adopted by Jackson. He was to be ready to interpose his good offices between Mexico and Texas, but not until Mexico should ask for them."

On the part of Texas, the election of Lamar and the formal withdrawal of the annexation proposal led into new channels of diplomacy. Hunt had warned Forsyth that if Texas were cast off by the United States, she would turn for aid to the powers of Europe, notably to France and England, who, he had no doubt, would be glad to avail themselves of the great advantages which a generous commercial treaty would give them. "The crowned heads of England and France, and their majesties' ministers," he said, "will not be altogether insensible to feelings of sympathy and regard for a people whose government is headed by individuals boasting their descent from the distinguished races over which their majesties preside." so Commercial advantages were more to be reckoned with than the English lineage of Sam Houston or the French ancestry of Mirabeau B. Lamar. The years 1838 and 1839 saw commercial treaties ratified with both France and Great Britain. At the beginning of 1840 Texas had been recognized as an independent nation by the United States, Great Britain, France, Holland and Belgium. It was no longer independent only in the eyes of the

" Forsyth to Ellis, May 3, 1839; MS., Archives.

${ }^{50}$ Hunt to Forsyth, September 12, 1837;H. Ex. Doc. 40, 25 Cong., I Sess., 15. 
United States. ${ }^{51}$ Texas had, therefore, a very different position from what she had when Jackson went out of office. Mexico refused to recognize Texas. Spain had refused for many years to recognize Mexico. It is a characteristic of Spanish diplomatic methods, as it is a part of the Spanish humor, to be oblivious of the awkward conditions of the present and to refuse to accept the inevitable. For four years Texas had maintained her independence by establishing relations with the great powers. That Mexico harassed her with threatened invasions and guerilla warfare added to the financial and political troubles of Texas, but it did not convince the world that Texas was still de jure any more than she was de facto an integral part of Mexico.

${ }^{51}$ See the interesting and comprehensive article by J. L. Worley upon "The Diplomatic Relations of England and the Republic of Texas," in the Quarterly of the Texas State Historical Association for July, I905, especially pages I-I5 for the events leading to the recognition of Texas by Great Britain. 
CHAPTER IV

The Relations Between the United States and Mexico During the Secretaryship of

DANIEL WEBSTER, I 84 I-I 843

The desire for Texas was not a mere creation of the Tyler administration. We know that at least a part of Texas was, and West Florida was not, a part of Louisiana, and that Monroe feared that Texas would prove an undesirable addition to the Union, its distance from the center of population tending to weakness rather than strength. Adams's opposition to the exclusion of Texas was expressed in his endeavor to purchase that province from Mexico. Jackson, who had not only acquiesced in the terms of the treaty of I819, but approved them, followed Adams's policy until the revolution in Texas changed the whole complexion of the question of annexation. Mexico had refused to sell Texas. When that state became independent, Mexico gave notice that if the United States annexed it she would declare war. Jackson thereupon held aloof and so did Van Buren. The stability of the Texan government was on trial. Texas must prove able to maintain itself. During the years in which Texas was allowed to rest, pending its successful assertion of independence, slavery had pushed to the front as the absorbing national issue through the debates in Congress upon the right of petition with which the name of John Quincy Adams is forever connected. The bitterness with which these debates were con- 
ducted threw the pro-slavery interests upon the defensive. They so remained until after the defeat of the Wilmot Proviso. Expansion to the southwest became indissolubly associated with slavery extension. The speeches of Adams and the brilliant although argumentative review of the subject by William Jay became the basis upon which Von Holst built his narrative of the Texas question. No one can read Von Holst's detailed presentation of the subject of annexation without being impressed by its plausibility, backed as it is by a mass of authorities, speeches in Congress, public documents, and extracts from party newspapers. At the same time one cannot fail to see Von Holst's reliance upon Adams, the most uncompromising as well as the most suspicious of antislavery statesmen. That stupendous human document, the diary of John Quincy Adams, a source of primary importance during the whole period of Adams's political life, becomes after I829 a repository of Adams's caustic criticism. No one who differed from him was given the credit of honesty. Those who, like Webster, prit the Union above abolition and believed that the carrying out of the compromises of the Constitution embodied the whole duty of the American statesman, were characterized as panderers to the vices of slavery. Thus Calhoun was "the high priest of Moloch;" Tyler, "the Virginian slave breeder;" and Webster "the man with a gigantic intellect, an envious temper, a ravening ambition, and a rotten heart." ${ }^{1}$ All this is interesting, but it is not history, nor is it a safe source from which to construct an historical narrative.

\section{${ }^{1}$ John Quincy Adams, Memoirs, XI., 284.}


Owing to the peculiar position in which Tyler found himself as a president without a party, every act of his became food for suspicion. Even the negotiations of which the Ashburton treaty was the successful outcome, unquestionably pursued in good faith, were said to have been conducted for the purpose of clearing the ground for pro-slavery expansion. ${ }^{2}$

As early as October, r841, upon the reorganization of his cabinet, Tyler expressed to Webster his views upon the annexation of Texas. "I gave you a hint as to the possibility of acquiring Texas by treaty. I verily believe it could be done, could the North be reconciled to it; would anything," he asked, "throw so bright a lustre around us? It seems to me that the great interests of the north would be incalculably advanc'd by such an acquisition. Slavery-I know that is the objection, and it would be well founded if it did not already exist, among us, but my belief is that a rigid enforcement of the laws against the slave trade, would in time make as many free States south as the acquisition of Texas would add of slave states, and then the future, (distant it might be), would present wonderful results." 3 Webster's opposition to annexation, however, was well known," and during his period of service under Tyler no attempt was made by the President to force his pro-annexation views upon his secretary of state. ${ }^{5} \quad$ How much Tyler's inaction

'William Jay, $A$ Reviere of the Causes and Consequences of the Mexican War, 87.

'Tyler to Webster, October II, I84I; Van Tyne's Letters of Daniel Webster, 240.

- Curtis's Webster, I., 560-70.

'Ibid., II., 227. 
was due to deference for Webster, who was engaged with England at first over the McLeod case and finally in the Ashburton negotiation, it is difficult to say. Delay was, however, prudent for several reasons: the importance of the pending negotiation with England; the objection in the North to southern expansion, which Tyler recognized; the opposition to annexation on the part of the Texan executive, Lamar; and the fear that annexation would be followed by a declaration of war by Mexico against the United States. As Tyler's term proceeded these causes for delay disappeared one by one.

Mexico had been quiescent toward Texas for four years and more. The war between Mexico and her revolted province resembled that between Spain and the Spanish-American states in the twenties. War existed, but it was not prosecuted. Technically there was a state of war; actually there was nothing more than a succession of threats. Texas, although financially depressed and burdened with debt, had managed to maintain herself for five years and had won not only recognition but a position of commercial importance in the eye's of the United States an I Europe. Her independen e was a fact a ln $i^{\prime+}$ ed by 1 the world save Mexico. $S$ ' 1 being the cas?, l.e te 'ons between Texas and tl Jnited States co id no a egally concern Mexico. I co might protest against annexation, she nt.ght ( ire war against the United States werejannex 1 insummated, but the moral basis of a be 1 rerent wde that she had justly. in 1836 was lo afte $e$ five years of Texan independence and her impotent - ttempt at the subjugation of her revolted province. the fears of war, which Jackson and Van Buren 
rightly measured, ceased to be a controlling factor after so long a period of waiting. The administration of Lamar ended and Houston, who had proposed annexation in 1837, was again president of Texas. Thus another cause for inaction was removed. With the ratification of the Ashburton treaty and the resignation of Webster as secretary of state another hindrance disappeared. There remained but to win over the Senate to the policy of annexation and Tyler would have the credit of doing what Adams and Jackson had failed to do. It was upon the support of the Senate that annexation was to hang. Perhaps it was due to the accident upon the Princeton (in which the secretary of state and other officers of the government were killed) and the appointment of Calhoun in the place of Upshur that the Texan treaty of annexation failed in the Senate. Tyler's plans were not based upon such an unforeseen and disastrous accident. This, however, is somewhat in advance of the story. Before Webster resigned and the annexation question was pushed to the fore, there were certain incidents of considerable importance in the relations between the United States and Mexifo,

The first was the no tiaciw f f r the release a number of Americali cil ens, if enbers of the ill ad Sa' a Fé sxpedition of I84I, who had been caf d 'ar were eld as prisoners of war. The secondels s ieoper : $g$ of the question of claims, into which th $t$ c. trie ac risition of California was interjected. The third was closely connected with the second: the violation of Mexican territory by the capture of Montere in Upper California by Co amodore Jones. 
While Texas had ever since its independence laid claim as far as the Rio Grande, no authority had been exercised over the territory west of the Nueces. Under President Lamar the Texan army had been disbanded for lack of funds with which to maintain it. By an irregular proceeding Lamar authorized members of the Texan army to organize an expedition to go overland to Santa Fé for the purpose of winning New Mexico for Texas and of extending the authority of Texas west of the Nueces. The expedition, consisting of about three hundred men, enrolled in addition to those who had taken the oath of allegiance to Texas a number of Americans and subjects of European powers. The expedition fared disastrously. Six members were taken prisoners and driven overland some two thousand miles to the City of Mexico, there to be held as prisoners of war. Among them was George M. Kendall, editor of the New Orleans Picayune, whose narrative of the expedition is of fascinating interest as a graphic account of border adventure. Kendall and the other Americans insisted that they were not in any sense identified with the expedition in so far as it had any hostile purpose toward Mexico. They claimed to be traveling for pleasure, or else that they were only traders. As soon as the capture of these men was reported to Ellis, the American minister at Mexico, he demanded their freedom, claiming that they should not be held as prisoners of war as they were non-combatants and had no connection with the alleged political purposes of the expedition. Ellis de-

- Kendall's Santa Fé Expedition; Yoakum's Texas, II., 32I31; Bancroft's North Mexican States and Texas, II., 334-37; Waddy Thompson's Recollections, passim. 
manded the release of the prisoners as a right. Santa Anna's government availed itself of the opportunity for delay that the discussion of the alleged right afforded. Mexico claimed that even if the prisoners were non-combatants they had violated a law of Mexico which forbade any entrance into the province of New Mexico from Texas, and that the Americans were like Old Dog Tray, in bad company, on account of which they should rightly suffer. The discussion was prolonged until Ellis received word that Tyler had appointed Waddy Thompson in his place. What Santa Anna had refused as a right he conceded as a matter of courtesy. Ellis's departure was the occasion for Santa Anna's promise that Kendall and his companions would be freed. Soon after Thompson's arrival the prisoners were set at liberty. All this was effected by Ellis, who was content to drop the argument if the object of it was attained.' Before the news of the prisoners' release reached Washington, Webster had penned a long protest in which he argued that Kendall and his friends were held in violation of all justice ; that the manner of their incarceration was contrary to the common dictates of humanity; and that unless the release of the prisoners was made within ten days after it was demanded, all intercourse with Mexico would be suspended. This letter of Webster's finds a place in his published works. Its contents were not made known to the Mexican government, the prisoners being at liberty before Webster's caustic letter was received at Mexico.

It will be remembered that through Forsyth and

'H. Ex. Doc. 27I, and S. Ex. Doc. 325, 27 Cong., 2 Sess. 
Martinez a convention had been arranged for the settlement of the claims of American citizens against Mexico through the arbitration commission. When this treaty had finally been ratified, April 7,1840 , and the necessary acts of Congress passed to carry it into effect, the year I84I was almost ended. Much time was lost in discussion of the methods to be pursued by the commission, and the period during which it was to sit expired with many claims still unconsidered. Webster proceeded to urge the settlement of these passed claims, together with a large number of additional ones which had never been presented for arbitration. It should be stated that the really valid claims were admitted by the commission. Much doubt may be cast upon those that were rejected and also upon those presented too late for consideration. Before anything had come of the matter, Mexico blazed up with threats of the subjugation of Texas and the vigorous prosecution of the war. Having at this time no minister in residence at Washington, the Mexican secretary for foreign affairs sent through an unaccredited person in New York $^{\circ}$ a protest against the assistance that citizens of the United States had been allowed to give Texas through the failure to enforce the neutrality laws. The government of the Mexican Republic protests "solemnly against the aggressions which the citizens of those states are constantly repeating upon the Mexican territory," and declares that "it considers as a violation of the treaty of amity the

'H. Ex. Doc. 29I; H. Report 1096; S. Ex. Docs. 320 and 4II, 27 Cong., 2 Sess.

'Joaquin Velazquez de Leon to Webster, June 24, I842; Webster's Diplomatic and Official Papers, 301. 
toleration of a course of conduct which produces an incomprehensible state of things, a state neither of peace nor war, but inflicting upon Mexico the same injuries and inconveniences as if war had been declared between the two nations." 10 Tyler characterized Bocanegra's note as impudent and deserving of a severe answer. ${ }^{11}$ Webster answered it through Thompson, who had succeeded Ellis as minister to Mexico. After a long review of the history of the struggle between Texas and Mexico, Webster denied that the United States had permitted any breaches of neutrality. Then he used a direct threat, the harshness of the tone of which comes out in strong relief when it is recalled that at the time he was writing it he had in contemplation a plan for the acquisition of California by pressure on Mexico through the claims. "Mr. de Bocanegra," he wrote Thompson, "is pleased to say that, if war existed between the two countries, proceedings more hostile, on the part of the United States could not have taken place. . . . This opinion, however hazardous to the discernment and just estimate of things of those who avow it, is yet abstract and theoretical, and so far harmless. The efficiency of American hostility to Mexico has never been tried; the government has no desire to try it. It would not disturb the peace for the sake of showing how erroneously Mr. de Bocanegra has reasoned; while on the other hand it trusts that a just hope may be entertained that Mexico will not inconsiderately and needlessly hasten into an experiment by which the truth or fallacy of his sentiments

${ }^{10}$ Bocanegra to Webster, May I2, I842; ibid., 302.

${ }^{11}$ Tyler to Webster; Tyler's Tylers, II., 258. 
may be brought to an actual ascertainment. The United States desires peace. It would be with infinite pain that they should find themselves in hostile relations with any of the new governments on this Continent. But their Government is regulated, limited, full of the spirit of liberty, but surrounded nevertheless with just restraints; and greatly and fervently as it desires peace with all states, and especially with its more immediate neighbors, yet no fear of a different state of things can be allowed to interrupt its course of equal and exact justice to all nations, nor to jostle it out of the constitutional orbit in which it revolves." ${ }^{12}$ This reply was but a threat. Webster said in effect: "Mexico thinks' she has suffered as much as she would have done had war actually occurred between her and the United States. Let her take care to act in such a fashion that she will never have to learn how erroneous that opinion is." Before Webster's reply reached Mexico, Bocanegra issued a circular note to the diplomatic corps residing in Mexico in which he protested against the violations of neutrality that the United States had tolerated, and announced that Mexico, though not willing "to disturb the relations which she still preserves with the United States, will assert and maintain the justice of her cause, which she considers to be based on the law of nations, by doing all that is imperiously required for her honor and dignity." 1 .

${ }^{12}$ Webster to Thompson, July 8, I842; Webster's Diplomatic and Official Papers, 304-15.

${ }^{13}$ Bocanegra to the Diplomatic Corps residing in Mexico, May 31, I842; H. Ex. Doc. 266, 27 Cong., 2 Sess., 19. Thompson to the Diplomatic Corps; ibid., 21. 
The purpose that animated Santa Anna in authorizing this bold manifesto is not clear, but it is probable that the circular was intended to offset the force of the understanding between Great Britain and the United States that the Ashburton-Webster negotiations seemed to imply. Thompson believed that certain members of the diplomatic corps had instigated Bocanegra's action. The Mexican notes to Webster and the circular to the diplomatic corps, which stated in substance that if the United States continued to tolerate what Mexico viewed as violations of neutrality Mexico would declare war, created a great sensation in the United States. Newspapers in all sections of the country declared that war with Mexico was inevitable, that Santa Anna had declared conditional war. There is no evidence that Tyler or Webster believed that Santa Anna's threat would be carried out. Thompson's reports made light of the danger, and no more was heard of the question until Commodore Jones, stationed with his small squadron off the coast of Chile, read about Mexico's conditional declaration of war in months-old newspapers which foretold immediate hostilities with Mexico. Meanwhile that country had recovered from its bad temper, and in the fall of I 842 sent a minister to Washington, General Almonte, the first to hold such a position since Gorostiza had demanded his passports in 1837 .

These details of diplomacy are rendered necessary because the charge has been made that Tyler's administration desired to push Mexico into a declaration of war. The same charge was made against Jackson. During Webster's term as secretary of state every effort was directed to the prevention of war. Mexico 
was told that "the war against Texas was not only useless, but hopeless, without attainable object, injurious to both parties, and likely to be in its continuance, annoying and vexatious to other commercial nations." 14 All of this was true, but further he did not go save once in the threat made through Thompson. When Almonte arrived in Washington the relations between the two countries were in better condition, with less open friction, than they had been since the battle of San Jacinto.

The method of publishing diplomatic correspondence in vogue at that day was by a communication to Congress upon the call of either house. How much should be printed rested usually in the discretion of the Executive. Extracts were frequently printed, when the whole letter, if known to the world, might have had an embarrassing effect. It was usual, however, but by no means the rule, to indicate what parts of the correspondence sent to Congress were extracts and what were full letters. The first despatch from Thompson, dated April 29, I842, was read by Webster May 30, not long before Bocanegra's note as above quoted was received. Upon a call of the Senate Tyler sent the parts of Thompson's letter upon the subject of the Santa Fé prisoners. Nothing in it showed that a part had been left out, yet a long argument by Thompson for the acquisition of California was omitted. "I believe," wrote Thompson, "that this government would cede to us Texas and the Californias, and I am thoroughly satisfied that this is all we shall ever get for the claims of our merchants in this country. As to Texas, I re-

${ }^{16}$ Webster to Thompson, June 22, I842; MS., Archives. 
gard it as of but little value compared with California, the richest, the most beautiful, and the healthiest country in the world. Our Atlantic border secures us a commercial ascendency there. With the acquisition of Upper California, we should have the same ascendency on the Pacific. The Harbor of San Francisco is capacious enough to receive the navies of the world. In addition to which California is destined to be the granary of the Pacific. It is a country in which slavery is not necessary and therefore, if that is made an objection, let there be another compromise. France and England both have had their eyes upon it. The latter has yet. I am profoundly satisfied that in its bearing upon all the interests of our country, the importance of the acquisition of California cannot be overestimated." ${ }^{15}$ Writing privately to Tyler soon afterwards, Thompson begged for special instructions both as to moving in the matter and as to the extent to which he was to go in the negotiation and the amount to be paid. The acquisition of California, he said, would reconcile the northern people, as they had large fishing and commercial interests in the Pacific, and we had literally no port there. ${ }^{16}$ Webster received Thompson's plea for the annexation of California favorably. "In seeking acquisitions to be governed as territories, and lying at great distance from the United States," he wrote, "we ought to be governed by our praience and caution, and a still higher degree of these qualities should be exercised when large territorial acquisitions are looked for, with a view to annexation. Neverthe-

${ }^{15}$ Thompson to Webster, April 29, 1842; MS., See Waddy Thompson's Recollections.

${ }^{16}$ Thompson to Tyler, May 9, 1842 ; MS., Archives. 
less, the benefits of a good harbour on the Pacific are so obvious, that to that extent at least the President strongly inclines to favor the idea of a treaty with Mexico." " Webster thereupon suggested connecting the claims with the negotiation for California (a plan which Polk afterward pursued), or at least for the port of San Francisco. England, he believed, would not hinder the United States. "You will proceed in this matter very cautiously and quite informally, seeking. rather to lead the Mexican Secretary to talk on the subject, than to lead directly to it yourself. You will be particularly careful not to suffer the Mexican Government to suppose that it is an object upon which we have set our hearts, or for the sake of which we should be willing to make large remuneration. The cession must be spoken of rather as a convenience to Mexico, or a mode of discharging her debts."

Tyler's inclination for California led no further than the writing of Webster's letter to Thompson and the sounding of Great Britain upon the question of the acquisition of California by the United States. Webster instructed Everett to make informal overtures to Her Majesty's government "for the settlement of the Oregon question, and the matters in dispute between Mexico and the United States by a tripartite arrangemert which should, as one provision, embrace a cession to thie United States of the port of San Francisco on the "coast of California." Lord Aberdeen informed Everett that "though the Queen's Government would not deem it expedient to become a party to any such

${ }^{17}$ Webster to Thompson, June 27, I842; Van Tyne's Letters of Daniel Webster, 269. 
arrangement, they had not the slightest objection to our making an acquisition of territory in that direction." ${ }^{18}$ The government at Washington learned early iil I843 that Commodore Jones (who two years before had been placed in command of the Pacific squadron) had seized Monterey in California under the false impression that war existed between the United States and Mexico. This Montery incident, partaking much of the character of opera bouffe, has doubtless had more attention paid to it than its intrinsic importance demands. Adams told Webster that he believed it to be, along with the question of the right of search, the bill for the occupation of Oregon, and all the movements for the annexation of Texas, part of one great system looking for a war for conquest and plunder from Mexico, and a war with England and an alli-

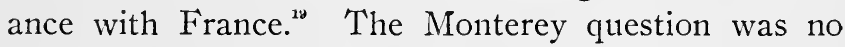
part of any preconceived plan, for it effectually put a stop to Thompson's negotiation for the acquisition of California in exchange for the claims against Mexico.

Jones's orders, which had been issued in December, I84I, can by no possible argument be construed as giving authority for any aggressive measures toward

${ }^{18}$ Everett to Calhoun, March 28, I845; MS., Archives. Webster's instructions to which Everett referred do not appear in the State Department files. Everett believed that Mexico might sell California because Bunsen told him that Mexico had previously offered it to Prussia.

${ }^{10}$ John Quincy Adams, Memoirs, XI., 346. Webster denied it. Certainly Aberdeen's attitude toward the purchase of California by the United States gave no basis for the belief that Webster looked for war with England. Von Holst (II., 6I5) quotes Adams's charge but omits Webster's denial. 
Mexico. On the contrary, while he was instructed to cruise along the coast of California and to explore its bays and harbors, he was cautioned to exercise great prudence and discretion "in avoiding all occasions of exciting the jealousy of either of the Powers having possessions or claims in that quarter, with whom the United States are, and desire to continue, at peace." ${ }^{20}$

In September, I842, Jones's squadron was at Callao. A British fleet left that port under sealed orders. Jones believed that it had sailed for California. "The Cxeole affair, the question of the right of search, the mission of Lord Ashburton, the sailing of a strong squadron from France under sealed orders, for the military occupation, as it now appears, of the Marquesas and Washington Islands; new difficulties between the United States and Mexico, the well-founded rumor of a cession of the Californias [to England] and lastly the secret movements of the English naval force in this quarter, have all occurred since the date of your last order to me. Consequently I am witho'st instructions, or the slightest intimation as to your views and wishes upon what I consider as a vital question to the United States-the occupation of California by Great Britain under a secret treaty with Mexico.” At first sight Jones's action was an indefensible outrage which had its incentive in his desire as a southerner to conquer California and to extend the area of slavery. A reading of his correspondence, however, tempers one's judgment of the man and of his

${ }^{20}$ H. Ex. Doc. I66, 27 Cong., 3 Sess., 46, 48.

${ }^{21}$ Jones to Upshur, September I3, I842; ibid., 68. 
deeds. Rumors of a secret cession of California to England were of long standing. ${ }^{22}$ It was openly stated that Mexico had mortgaged California to secure a large loan. Such indeed was not the case, but the repeated rumor was calculated to operate upon Jones's judgment. The account of Bocanegra's circular to the diplomatic corps, as given in American newspapers, reached Jones months after the incident had closed. At such a distance from home and without instructions, Jones decided to crowd all sail to California, to frustrate the British fleet and, believing that war would be the inevitable result of Bocanegra's circular, to take possession of Monterey, the capital of Mexico's province. Jones's judgment was, as the sequel showed, faulty, but had he been right in his conjecture he might have been a precursor of Dewey: the conqueror of California and a hero in our naval history. The commodore appeared off Monterey October ig. He found no British vessels in the harbor. The dilapidated "castle," mounting a few old guns, made no hostile front. Jones demanded the surrender of the town and province. Without the firing of a shot, the Mexican flag was lowered and the American flag raised. That night Larkin, a merchant of Monterey, and afterwards American consul (and an active agent in the final conquest of California), showed Jones that more recent advices demonstrated that the United States and Mexico were still at peace. Jones acted promptly, lowered the American flag, raised and saluted that of Mexico, and departed. He was now aware of the risk

${ }^{22}$ Ashburton wrote to Webster, April 28, I844, that he believed Great Britain never dreamed of acquiring California. Webster's Private Correspondence, II., 192. 
he had assumed. In his report upon the affair he said: "I may be wrong in all my deductions and conclusions. If so, I may forfeit my commission and all that I have acquired in seven and thirty years' devotion to my country's service. Terrible as such a consequence would be to me and my family, it was not sufficient to deter me from doing what I believed to be my duty, when a concatenation of unforeseen and unforeseeable events rendered prompt and energetic action necessary for the honor and interest of my country. Come what will, I have the proud satisfaction of believing, that however severely my judgment may be condemned, no one will question the motives which impelled me to action." ${ }^{23}$

Upon the receipt of the news of Jones's ill-advised action, the secretary of the navy recalled him from his command. He returned to Washington for an inquiry and was temporarily suspended from the service.

Thompson at Mexico, without waiting for instructions upon the subject, disavowed Jones's act and promised complete reparation for all injuries done. After some correspondence between Thompson and Bocanegra at Mexico and between Webster and Almonte at Washington, the matter was adjusted. Almonte demanded Jones's punishment for the "inaudito atentado" against Mexico." Webster apologized for the affront to the dignity of Mexico, and expressed the great regret of the President at what had happened and the conviction that "no such unfortunate and un-

${ }^{23}$ Jones to the Secretary of the Navy, October 24, 1842 ; H. Ex. Doc. I66, 27 Cong., 3 Sess., 70.

${ }^{24}$ Almonte to Webster, January 24, I843; ibid., 3 . 
authorized occurrence ought in any degree to impair the amicable relations subsisting between the two countries so evidently to the advantage of both." ${ }^{25}$

The Monterey incident peaceably disposed of, attention was again directed to the question of claims, which was never allowed to lie idle for any length of time. In January, I843, Thompson made an agreement with the Mexican government extending the time for payment of the claims under the arbitration award. As to the claims not adjusted, which he was instructed to press for settlement, Thompson was not enthusiastic. In a communication to Congress Tyler reported a letter from Thompson in which he complained that "claims of the most manifest and admitted justice were postponed from day to day and from year to year." A further comment of Thompson's was omitted. Among the pending claims was one of William S. Parrott for six hundred and ninety thousand dollars, which was based largely upon the seizure of a lot of bottled porter. "These claims," Thompson reported, "are not of such a character as to justify menace and the execution of that menace if compliance is refused. I am constrained to say that if they were referred to me as a judge, I could not admit them, nay more, I cannot with a clear conscience assist them." Parrott's claim was exaggerated, he said, to a disgusting degree. "To assist such a claim would subject both me and the Government to ridicule, if nothing worse." ${ }^{26}$ Nevertheless he followed his instructions and saw some prospects of success. "When I came

${ }^{25}$ Webster to Almonte, January 30, I843; ibid., 5

${ }^{26}$ Thompson to Webster, November 30, I842; MS., Archives. 
here," he said, "the claims were not worth twenty cents on the dollar. I regard them now as worth par." ${ }^{27}$

Nothing was accomplished further than this upon the claims while Webster was in office. The pressure which had been exerted upon him to resign had never lost, but had gained force. His reasons for continuing as secretary of state had no longer any binding strength. The Ashburton treaty had been concluded and ratified by a larger vote in the Senate than Webster had hoped for. ${ }^{28}$ The peace had been kept with Mexico notwithstanding a series of vexatious incidents which might easily have led to a breach. Webster's diplomatic activities during his two years as secretary had been fruitful in other directions, particularly by the opening of diplomatic relations with China and of consular relations with Hawaii. ${ }^{20}$ The subjects of the Danish Sound dues and of the change in our commercial relations with the German states by the formation of the Zoll-Verein, a complete discussion of which belongs to a later period, also claimed Webster's attention. ${ }^{30}$ But with the Ashburton treaty ratified and in force, Webster had no further desire to remain in Tyler's official family. Fortunately, before he left the cabinet he was able to straighten out a misunderstanding over the article in the treaty of Washington providing for joint cruising against the slave-trade. ${ }^{31}$

${ }^{27}$ Thompson to Webster, January 31, I843; MS., Archives.

${ }^{28}$ Webster to Jeremiah Mason, August 2I, 1842; Webster's Private Correspondence, II., I46.

${ }^{29}$ John W. Foster's American Diplomacy in the Orient; J. M. Callahan's American Relations in the Pacific and the Far East.

${ }^{30}$ Webster's Diplomatic and Official Papers, 382-92.

"I Ibid. 
In his message at the opening of Congress in 1842 Tyler approved the course of Cass in protesting against the quintuple treaty. He praised the jointcruising article of the Ashburton treaty as an indication of the American position as to the right of search. The message reached England and gave rise to a spirited debate in Parliament and a letter of inquiry from Aberdeen as to Webster's construction of the article. Ashburton wrote Webster that the question of the right of search had never been discussed between them, and that the joint-cruising convention had been adopted as a practical measure for the accomplishment of a specific purpose. In this view he was correct. As has been said, it was a plan suggested by Tyler and agreed to by Ashburton. Webster wrote to Everett that the right of search had had no place in his negotiation with Ashburton; that no concession was asked of, or given by, Great Britain. Following this up, he elaborated upon the falsity of the distinction made between right of visitation and right of search. Aberdeen, upon reading it, told Everett that he concurred in every word of the despatch and that he agreed that there was no distinction between the right of search and that of visitation. It was an amiable reception of what proved to be Webster's valedictory. The attack upon Ashburton for having signed a "capitulation" was changed into a vote of thanks by Parliament, as Webster's so-called "surrender" had been ratified by the overwhelming vote of the Senate.

The settlement of the northeastern boundary, the adoption of a practical method for the extinction of the slave-trade by preventing a fraudulent use of the 
American flag, and the incorporation into public law of the principle of extradition were diplomatic honors enough. After a short time no one of common sense cared, as Ashburton said, about the precise position of Lake Pohenagamook. " "The merit of the settlement was that it would not stand the description of a sharp bargain."

The quarrels between Tyler and Congress and the divisions of the Whig party are not within the scope of the present inquiry. The reasons that led Webster to resign from Tyler's cabinet, in so far as they were political, do not belong to the diplomatic history of the period. As has been stated, the Oregon question had been omitted from the Ashburton negotiation, and Webster hoped to settle this himself by a special mission. During the winter of 1843 such a special mission was contemplated and the consideration of it reluctantly dropped by Tyler. ${ }^{33}$

The business to be undertaken by Webster in this special mission was intricate and delicate. The settlement of the Oregon question was of course the first and most important. Although Ashburton had not entered into that matter, he was reported to have stated to Webster that he thought England would make no objection if Mexico would concede something south of our boundary of forty-two degrees across the continent, so as to include the ports of San Francisco and Monterey. ${ }^{34}$

${ }^{32}$ Ashburton to Webster, January 2, 1843 ; Webster's Private Correspondence, II., I62.

${ }^{33}$ Webster to Everett, January 29, I843; Curtis's Webster, II., I76.

${ }^{34}$ J. Q. Adams, Memoirs, XI., 347; Tyler's Tylers, II., 260. 
Then the President suggested sending Everett from the Court of St. James to China as a special commissioner to open diplomatic relations with the empire of the Far East. The position of minister to Great Britain was to be the door by which Webster might gracefully let himself out of the cabinet. ${ }^{35}$ In September, I84I, one of Tyler's Virginia friends, Wise, had suggested this: "in no way can we jilt Webster except by sending him to England." " ${ }^{36}$ Upshur was to take Webster's place as Tyler's secretary of state. The position of commissioner to China did not tempt Everett, who preferred to remain where he was. Ashburton, upon hearing that Everett might leave England for the "Celestial Empire," said that he would be much too fine an instrument for such a purpose. "It would be cutting blocks with a razor." ${ }^{\prime 37}$ It is no mere coincidence that Webster's resignation was placed in Tyler's hands May 8, I843, the same day upon which Everett's positive declination was received. Everett could not be recalled to make room for Webster. Every consideration of friendship, of loyalty, and even of political expediency prevented that. After the China mission had been suggested to Everett and declined by him, no course was left to Webster but to resign. With Webster's place to fill, Tyler's break with the past was complete. Hugh S. Legaré, the attorney general, was made secretary of state ad in-

${ }^{35}$ Tyler's Tylers, II., 263, note. Cf. Webster to Everett, January 29, I843, ut sup. John Quincy Adams, Memoirs, XI., 347 .

${ }^{36}$ Tyler's Tylers, II., I20.

${ }^{37}$ Ashburton to Everett, April 28, I844 (I843); Webster's Private Correspondence, II., 192. 
terim. A week after his retirement Webster wrote that in his judgment Upshur, the secretary of the navy, would be appointed. "The President's range for choice is limited," he said. "Mr. Upshur is an accomplished lawyer, with some experience abroad, of gentlemanly manners and character, and not at all disposed to create, or to foment foreign difficulties. How much of general comprehensiveness and practical ability he possesses is yet to be evinced. I think the President could not at present have done better." ${ }^{38}$

At this time, however, Webster was not as fully in Tyler's confidences as might be supposed. Calhoun seems to have known, two months before Webster's resignation was in the President's hands, that there would be a change in the state department, and that Upshur would be Webster's successor. The choice of Upshur was entirely satisfactory to Calhoun and his friends. "It would give him [Upshur]," so Calhoun wrote to Duff Green, "a commanding position in which he might exert a very salutary influence over the important questions that are likely to grow out of our foreign relations the next few years."

Thus ended the first half of Tyler's administration, and with the resignation of Webster the opponent of the annexation of Texas left the President's councils. In his place came Upshur, who put into execution Tyler's long deferred plan. Thenceforth during the remainder of Tyler's administration every effort was made to recover what Tyler claimed Monroe's admin-.

${ }^{38}$ Webster to Everett, May I2, I843; Webster's Private Correspondence, II., I73.

${ }^{30}$ Calhoun to Duff Green, February (March) I9, I843; Report of the American Historical Association, I899, II., 526. 
istration had suffered to be lost. The reannexation of Texas was the policy of Tyler. His new secretary of state lost no time in planning a campaign that might make the policy effective and Texas a part of the American Union. 


\section{CHAPTER V}

The Negotiations for Texas Under Upshur

$$
\text { I843-I } 844
$$

After the departure of Webster from the cabinet of Tyler the long-suppressed inclination of the President for the annexation of Texas manifested itself. With the appointment to the head of the state department of Upshur, whom Tyler's Virginia friends had been urging for the place since the first reconstruction of the cabinet in September, I84I, the question of Texas pushed to the fore to the exclusion of every other matter of foreign affairs. How long before Webster's resignation the cabinet had been in a ferment over annexation it is scarcely possible to state definitely.

In December, I84I, John Quincy Adams was told that the proffer of annexation, withdrawn by Texas in 1838 , would soon be renewed, but he confessed that the developments of the project were not yet sufficiently clear and explicit to know how to meet and counteract it. ${ }^{1}$ Newspapers south and north discussed annexation pro and con, but no one believed that there could be found a majority of either house of Congress favorable to the measure upon any former terms. Until Lamar's retirement from the presidency of Texas, late in I84I, no action was taken reversing the decision made three years earlier, which finally withdrew the proposal of Texas to the United States.

${ }^{1}$ John Quincy Adams, Memoirs, XI., 4r. 
From the inauguration of Lamar's successor the policy of Texas swung back to what it had been during Houston's former term, when through him overtures for annexation had been made to Van Buren and finally declined. There was no mistaking the temper of the people of Texas upon the question, for they could imagine no other outcome than the incorporation of their nation with the United States. As to the officers of the government of Texas, it is not so easy to speak. Houston's sincerity in his favorable attitude. to annexation has been questioned and denied. Some have thought that in his heart he really preferred the independence of Texas, if that could be maintained, even with the aid of Great Britain and France. Others have believed that during the years from I84I to I8.44 he was merely "coquetting" with Great Britain in order to force the hand of the United States; and further that he gave all the prominence possible to the alleged intrigues of Great Britain with Texas in order to develop in the United States a sentiment for annexation as a measure of defense against the encroachments of the former country. ${ }^{2}$ There is much that points to such an explanation of the sinuous course that Houston adopted, but proof is lacking that any definite understanding existed between the executives of the United States and Texas. Indeed, the evidence points away from any understanding whatever. The truth seems to be that Houston made up his mind that the United States could be forced into a positive attitude upon annexation; that Texas and not the United States should appear to be in a receptive attitude; that

${ }^{2}$ Worley in the Quarterly of the Texas State Historical Association, July, I905, 40. 
the United States and not Texas should be the one to press the proposal for annexation. Houston's idea seems to have been to put the United States into an aggressive position, in which Texas might drive as good a bargain as possible. ${ }^{3}$ It is significant that the negotiations for the annexation of Texas were conducted at Washington. It is even more significant that the American chargé in Texas, William S. Murphy, was kept uninformed for two months that his government had proposed annexation. Early in his second administration Houston made an overture for annexation only to withdraw it. Then the United States reopened the question. Houston declined to consider it. The Texan Congress overruled the president's declination, but it availed nothing until Houston had managed to obtain from the United States assurances of protection pending any negotiation. These had, Houston agreed to annexation. This much in outline is set forth here, in advance of the proper and orderly presentation of the narrative, for the purpose of emphasizing what is believed to be the key to Houston's diplomacy during Tyler's administration. During the negotiation with Texas the scene shifts from Washington to Texas, thence to London and back again. All lines of the narrative must be kept in mind. The events in Texas as well as those at Washington and at London are important for a correct appreciation of the development of the policies of Houston and Tyler.

${ }^{3}$ Anson Jones (Official Correspondence, passim) impugns Houston's motives and claims to have been alone steadfast for annexation, although he admits that there was a game played toward France and England. 
Before Houston had been in office five months he despatched a new representative to Washington, James Reily, whom he authorized to renew the proposal for annexation." Reily frankly confessed that the time was not ripe for the United States to act." Tyler he found enthusiastic and "sincerely desirous of consummating annexation immediately. . . . The President would act in a moment if the Senate would assent." • Tyler's enthusiasm was shared by others. "Although annexation was spoken of by the few warm and ardent friends of the measure, including the President, R. J. Walker, Upshur and Gilmer, Dr. Gwin of Mississippi, and others useless to mention, yet at no time [during Reily's short residence at Washington] was it discussed as a probable event. All parties were satisfied that no treaty of annexation would be ratified by the Senate, and there was not even a majority in favor of the policy in the lower House." " So Reily reported upon the state of feeling during the summer of 1842 . There were manifold reasons why the question could not then be brought forward. The Ashburton negotiation was in itself enough to engage the entire attention of Tyler. Webster was opposed to the measure. The character

\section{"Jones, Official Correspondence, 38.}

'Reily to Jones, March 25, 1842: "I would rather die than remain here. . . . Nothing can be done here in the way of negotiations for Texas." Ibid., 178.

'Reily to Jones, July II, I842; Yoakum's Texas, II., 347. Houston to Jones, August 2, 1842: "In Reily's place I have sent Van Zandt to Washington. He will be prudent and will not jump high enough to endanger his safety." Jones, Official Correspondence, 186.

'Niles' Register, LXXIII., I47, quoted by Tyler, Tylers, II., 256 . 
that the Texans had shown in their Santa Fé expeditions-the first, which Kendall accompanied, and the second, known as Sniveley's expedition-was not such as to gain them additional moral support. Possibly the former and certainly the latter of these expeditions was a mere freebooting enterprise. The members of the first had been captured by the Mexicans and liberated only through the determined efforts of the representatives of the United States. Sniveley's command had been disarmed by a detachment of United States troops near the border. "The first step," wrote Jackson to Houston, "that led to the injury of the fame of Texas, was that foolish campaign to Santa Fé; the next the foolish attempt to invade Mexico, without means or men sufficient for the occasion." s Texan military enterprise came to be looked upon in the United States, even by the friends of Texas, as guerilla warfare, unredeemed by the appearance of a defensive undertaking. Thus the character of Texas as an independent nation had sunk in the estimation of the American people. A further reason why Tyler deferred any action was that the Mexican claims were under discussion. Finally, the United States and Mexico were upon a more friendly footing, so that there were reasons enough for Tyler's declination of Houston's offer delivered through Reily in July, I842. It would have been a waste of time to hazard the question of annexation. All that Houston's agent accomplished was an agreement with Webster for a commercial treaty. This the Senate rejected upon the ground that

${ }^{8} \mathrm{Jackson}$ to Houston, August 31, I843; Yoakım, Texas, II., 406. 
such a treaty with Texas would interfere with the prosecution of the claims against Mexico. In the fall of 1842 Houston sent another agent, Isaac Van Zandt, who repeated the offer made by Reily. Tyler again declined the proposal. So far Houston had met with failure in every attempt looking toward an understanding with the United States. The experience with Jackson and Van Buren was being repeated.

With this rejection of the offer as proposed by Van Zandt, Houston began upon a new theory. This was to cultivate by every means possible the jealousy with which the United States regarded Great Britain. The first step in this policy was to reconsider the offer made by Van Zandt and declined by Tyler. Houston instructed Van Zandt to say to the authorities of the United States that it would now be necessary for the United States to make an advance so decided as to open wide the door of negotiation to Texas. Should that be done Texas would renew the proposal for annexation.

Houston was not compelled to wait long for the sentiment in the United States to assume an aggressive character. Gilmer of Virginia, who with Upshur was in closest contact with Tyler and in his confidence, published a letter in which he put forward the "reannexation" of Texas to the United States as the immediate duty of the government. This letter of Gilmer was, according to Benton, the first step in a great conspiracy which had for its object not only the an-

'Jones to Van Zandt, February I0, I843; Yoakum's Texas, 'II., 407. 
nexation of Texas (no great wrong in itself in Benton's eyes), but the promotion of the candidacy of Calhoun, who avowedly aspired to be Tyler's successor. This meant the defeat of Martin Van Buren for the Democratic nomination in 1844 . The most detailed treatment of the subject is that of Von Holst, who in following Benton's view of an intrigue in the interests of Calhoun makes his narrative revolve about the political situation that resulted in the defeat of Van Buren in the Democratic convention of I844. The charge of Benton-that Tyler's enthusiasm for Texan annexation was but a part of an intrigue to fasten Calhoun upon the Democratic party-does not seem to be well sustained. If such an intrigue existed, Tyler was obviously ignorant of it. He was from the beginning of his term enthusiastic for Texas. We have seen the forces that hindered his enthusiasm from becoming effective. Gilmer's public letter advocating immediate annexation was claimed to be the first direct act of the Calhoun intriguers. The tone of this letter is sufficiently explained by the status of the relations with Texas. That the letter appeared soon after Calhoun had resigned from the United States Senate is probably coincidental. There is nothing in Calhoun's correspondence to show that there was any connection between his resignation from the Senate and his presidential candidacy on the one side, and the annexation of Texas on the other. It is difficult to see how the advocacy of annexation would at that time have furthered Calhoun's political chances. Perhaps this was merely a ruse. It is difficult to frame a theory of the Tyler-Texas-Calhoun propaganda with which all the facts fit perfectly. Calhoun was, and had been for 
a long time, favorable to Texan annexation. So was Tyler. So was Jackson until the responsibility of office and his regard for Van Buren as his successor made him cautious. Tyler, without a party, believed the time ripe for annexation. He was surrounded by Calhoun's friends, Upshur and Gilmer among the number. Calhoun resigned from the Senate and was nominated by South Carolina for the presidency two years before the national convention was to meet. The purpose was, of course, to defeat Van Buren. Calhoun emphasized his position upon the tariff, upon which he was in opposition to Van Buren's friends. Upon the tariff, he believed, Van Buren was prostrated in the south, ${ }^{10}$ and Texas came after the tariff as a subject upon which the South could unite. Calhoun favored it. Van Buren finally opposed it. Tyler was the instrument by which annexation was brought forward by Calhoun's friends, but in the end neither Calhoun, nor Van Buren, nor Tyler made political capital out of the Texas question. It resulted, however, in throwing Van Buren overboard, which many southern Democrats had determined upon as early as I84I. Annexation was not broached through Calhoun, but through Calhoun's old enemy, Jackson. Gilmer's letter to the public was sent to Jackson by a member of the House from Tennessee. It was no coincidence that Houston wrote Jackson at the same time. The reply from the Hermitage was couched in as strong terms as the increasing body of annexationists could desire.

The suspicions of John Quincy Adams took fire at the aggressive attitude of the annexationists. Early

${ }^{10}$ Calhoun to Duff Green, August 31, 1842; Report of Am. Hist. Association, I899, II., 516. 
in March, 1843, he joined with twelve colleagues of the lower house in an address to the people of the United States, warning them against the machinations of the administration to secure the extension of slavery by adding Texas to the Union, pointing out the gross violations of our neutral obligations toward Mexico, and calling upon the free states for renewed and increased activity to avert the calamity with which the country was threatened. At the time Adams's address was published there was no proposition for annexation pending, so far as the records show. The month before Van Zandt had determined to let the matter rest while the United States made the move."

At this juncture Houston had the advantage of a series of events which, better than any he could have devised, served to awaken the jealousy of the United States toward Great Britain. Santa Anna had threatened to renew the war against Texas, so Houston asked that the United States, Great Britain, and France, acting jointly, mediate between his country and Mexico. Great Britain declined to join with the other powers in mediation, but promised by acting alone to interpose her good offices for the termination of the war. Santa Anna was prevailed upon by Doyle, the British chargé in Mexico, to submit an armistice to Houston. Doyle, in Mexico, and Elliott, the British chargé in Texas, were occupied during the spring and summer of 1843 with the arrangement of this armistice. Whether or not Houston was sincere in his de-

${ }^{11}$ The petitions for and against annexation presented to both houses of Congress from now on displayed the increasing importance of the subject. 
sire for an armistice with Santa Anna is not to be decided. Doubtless the armistice was an effective method of delaying hostile aggressions by Santa Anna, and Houston made the greatest possible use of it to arouse the jealousies of the United States by throwing into prominence the activity of the British agents who arranged the truce.

Although advised by Elliott that he had no doubt of Mexico's ultimate refusal to treat with Texas unless the sovereignty of Mexico were acknowledged, Houston proclaimed the armistice and sent commissioners to meet those selected by Santa Anna. ${ }^{12}$ No time was lost in putting the correspondence with Elliott upon the subject of the truce into the hands of the United States government. The reply of Anson Jones to Elliott accepting Santa Anna's proposition was immediately sent to Van Zandt at Washington. ${ }^{13}$ While Elliott was busy in transmitting the correspondence between Texas and Mexico, the American chargé, General William S. Murphy, who had but just arrived in Texas, observed the proceedings with growing indignation. He was forced to sit by and see Texas fall into the power of England, as he believed, through the exertions of Houston. Not a word was said to him about the armistice (although it was fully reported to Van Zandt for the information of the administration at Washington), and he was allowed to be as fully impressed by the activity of the British agent as was possible. Finally, under professions of great secrecy, Jones gave Murphy copies of the correspondence, with

${ }^{12}$ Houston's proclamation was dated June I3, I843. 409.

${ }^{13}$ Jones to Van Zandt, June 5, I843; Yoakum, Texas, II., 
the injunction that Houston must never know that the secret had been let out. Jones's ruse was successful." Murphy wrote home that England's power over Houston was complete; that the executive of Texas was determined to take a position in opposition to the wishes of the people of Texas, which were well known to be favorable to annexation. "The armistice has been accepted by this Government," he wrote, "and proclaimed to the world, but what steps are now in progress, I know not, nor can I know until they should disclose themselves to the world. England may at this time be setting on foot a negotiation of vast consequence to the United States, and in all probability such is the case." ${ }^{15}$

At about the time that Murphy's report of the armistice was received, Tyler's attorney general and acting secretary of state, Legaré, died. Upshur, the secretary of the navy, was transferred to the state department. At this point also appears a new character upon the scene, who on account of his close friendship and intimacy with Calhoun added force to the charge that the Tyler pro-annexation policy was really a part of the Calhoun propaganda. This new factor in the Texas question was General Duff Green, whose daughter had married Calhoun's son. Green's son, moreover, Benjamin E. Green, was the American chargé in Mexico. In the summer of 1843 Duff Green was in England endeavoring to sound the public men of Peel's

${ }^{14}$ Murphy to the Secretary of State, enclosing copies of the correspondence of Elliott and Jones. MS., Archives.

${ }^{15}$ Murphy to the Secretary of State, June 5, I843, received July 8; MS., Archives. Murphy was not presented to Houston until June I7, I843. Jones, Official Correspondence, 38. 
cabinet as well as those of the opposition upon the subject of reciprocal free trade. Soon after his departure Calhoun wrote him: "I must say, that I have not much hope, that anything satisfactory can be done in the form of an arrangement, although I do not doubt the sincerity of the Government on either side. The difficulties are great, but if an equal and fair arrangement can be made, I do not doubt its expediency. I am for free trade; free trade on both sides if it can be had; but if not, on one side." ${ }^{16}$ Green soon found that he could do nothing with Peel's administration. He then placed his hopes in the Whig opposition. He reported that Lord John Russell told him that the ministry would be assailed in their American policy; that if Palmerston returned to power, his party would "go for free trade with America and an immediate adjustment of the Oregon question, for the arlmission of slave-grown produce, and non-interference in the domestic policy of other nations; that they will denounce the attempt to emancipate the slaves of Cuba, Brazil, the States and Texas as illegal and unwise interference." ${ }^{17}$ Green's advice was that the United States should assume an aggressive position toward Texas. He believed that the antislavery party in England was losing influence. "If our government can be induced to take strong ground on the question of Texas, the free trade party here will rally for us against the fanatics, and the Whigs will make the refusal of ministers to meet the proposition of our Government a matter of serious assaults." 1s

${ }^{16}$ Calhoun to Green, June 7, I843; Report of Am. Hist. Association, I899, II., 537.

${ }^{17}$ Green to Calhoun, August 2, 1842 (1843?) ; ibid., 846.

${ }^{18}$ Green to Calhoun, September 2, 1843; ibid., 871 . 
While Green was thus sounding the opposition upon its attitude toward the United States, Ashbel Snith, the Texan chargé at London and Paris, succeeded in obtaining from Lord Aberdeen the views of the British ministry toward Texas. ${ }^{19}$ Great Britain had but recently recognized the independence of Texas and was then active, as has been seen, in arranging an armis-

\& tice between Texas and Mexico. Public sentiment in England was outspoken in favor of the abolition of slavery. Stephen P. Andrews, noted as an antislavery agitator, now appeared in London as an agent of the abolitionists of Texas, with a proposition that Great Britain should advance a loan to Texas to be applied to the purchase and emancipation of Texas slaves. Smith repudiated Andrews to Lord Aberdeen, saying that his visit to London was his individual act, unauthorized by the government or citizens of Texas. The chargé reported to Jones, the Texan secretary of state, the substance of his interview with Aberdeen upon the subject of Andrews's visit and upon the more general topic of Great Britain's attitude toward Texas. He told Aberdeen that he had reason to think no disposition to agitate the subject of slavery existed on the part either of the government or of any respectable portion of the citizens of Texas. "I also stated to Lord Aberdeen that I was informed representations would be sent out to Texas, based on statements made by members of the Antislavery convention [recently held in London], who had recently called on his Lordship touching this matter, to the effect that Her Majesty's Government would afford in some way the means for

${ }^{10}$ Smith to Jones, Paris, August 2, 1843; Jones, Official Correspondence, 236 . 
reimbursing or compensating the slaveholders, provided slavery were abolished in our country. I enquired what grounds there was for these assertions. His Lordship replied in effect: That it is the well known policy and wish of the British Government to abolish slavery everywhere-that its abolition in Texas is deemed very desirable. . . . He added that there was no disposition on the part of the British Government to interfere improperly on this subject, and that they would not give the Texian Govt. cause to complain. He was not prepared to say whether the British Govt. would consent hereafter to make such compensation to Texas as would enable the slaveholders to abolish slavery. The object is deemed so important, perhaps they might, though he would not say certainly." ${ }^{20}$ Such was the Texan chargé's report of Lord Aberdeen's position upon the subject of abolition in Texas. It was written soon after the event and there is no reason for believing it in any wise incorrect.

Green, however, disturbed by the increasing sentiment for abolition, looked upon the activities of Andrews as a menace to the interests of the United States. He wrote that Aberdeen had told Smith that the British government deemed it so important to prevent the annexation of Texas to the United States that they were prepared to support the loan if it should be required to prevent annexation. ${ }^{21}$ Whether Smith imposed upon Green, or Green colored the correct statement; it is impossible to say. The true account of

${ }^{20}$ Smith to Jones, July 3I, I843; Report Am. Hist. Association, I899, II., 867. Cf. Ashbel Smith, Reminiscences.

${ }^{21}$ S. Ex. Doc. 34I, 28 Cong., I Sess., I 8 . Quoted by Upshur to Murphy, August 8, 1843 . 
Aberdeen's interview with Smith was probably not in the hands of the state department at Washington until the spring of 1844 . Green's reports helped to fill

- Tyler and Upshur with as much jealousy of Great Britain's power over Texas as Houston could possibly have desired. Through the agency of Duff Green, therefore, Tyler's policy toward Texas was to some extent molded. Texas must be annexed as a measure of self-protection to the United States against the enencroachments of Great Britain, which, by obtaining an influence over Texas, might dispute with the United States the commercial and naval supremacy of the Gulf of Mexico. More than this, Texas must be annexed to the United States in order to protect the slave interests of the southern states, so jeopardized by Great Britain's advocacy of abolition in Texas.

For the first time in its history the government deliberately assumed a position to the world that in international relations the United States stood for slavery; that the United States was nationally a slave power and opposed to abolition in a neighboring state as a menace to its own interests. Expansion had been postponed until 1843 by fears of a war with Mexico and by the opposition that the antislavery sentiment fostered and encouraged. In the negotiation for Texas which Upshur and Calhoun conducted the extreme position was taken: Texas must be annexed, lest by remaining independent under the domination of Great Britain she might abolish slavery. That the United States should press for annexation as a means of neutralizing the efforts of Great Britain to obtain an ascendancy over Texas was a legitimate and proper course, if the government sincerely believed that such 
was Great Britain's ambition. That Tyler's administration based its opposition to Great Britain's ascendancy upon the ground that it looked toward abolition in the independent state of Texas is quite another matter. Tyler's fear of the influence of Great Britain was in itself not surprising. It is not, however, so easy to defend the ground that he actually assumedthat anything that tended toward the abolition of slavery in America was a menace to the national interests of the United States. The assertion that American supremacy demanded Texan annexation was logical and natural. The weakness of Tyler's method of asserting that supremacy lay in the declaration to the world that the interests of slavery demanded annexation. The United States stood before the world, not as a defender of slavery merely, but as the aggressive champion of it, determined that where slavery existed, there it should remain. Duff Green's reports and Upshur's instructions based thereon give, therefore, the starting point to the negotiations of which the rejected treaty of annexation was the result.

"I am authorized by the Texan minister to say to you, that Lord Aberdeen has agreed that the British government will guarantee the interest [upon a loan] upon condition that the Texan government will abolish slavery." ${ }^{22}$ So wrote Green to Upshur. Upon this information incorrectly stated by either Green or Smith the secretary proceeded to act. He wrote Mur-

${ }^{22}$ Quoted by Upshur as "a private letter from a citizen of Maryland, then in London," in Upshur's instructions to Murphy, August 8, I843; H. Ex. Doc. 27I, 28 Cong., I Sess., 18; S. Ex. Doc. 34I, 28 Cong., I Sess.; Ashbel Smith, Reminiscences, 52-55. 
phy in Texas, quoting Green's letter without naming the writer. A movement by Great Britain of the sort described could not, he said, "be contemplated by us in silence. Such an attempt upon any neighboring country would necessarily be viewed by this Government with very deep concern, but when it is made upon a nation whose territories join the slaveholding States of our Union, it awakens a more solemn interest. It cannot be permitted to succeed without the most strenuous efforts on our part to arrest a calamity so serious to every part of our country." The secretary then proceeded to elaborate his argument for "arresting the calamity." If the movement were confined to the abolitionists of Texas, he would find little concern, for he knew they were few in numbers and weak in influence. He beheld in England's action, however, a part of a general plan for the abolition of slavery throughout the world, as a means of holding her own commercial supremacy threatened by slave labor. "No other adequate motive can be found for her determined and persevering course in regard to domestic slavery in other countries." England's attitude toward Texas was, he said, based upon this motive. It was the control of the destinies of Texas at which she aimed. Abolition of slavery was but a handle for the raising of such a policy. Important, however, as England's supremacy might be, he further stated, "there was another view of the subject still more important to us and scarcely less important to Texas herself." This was the existence of a republic without slavery, adjoining the slave states of the South. He dwelt upon the horrors of a system by which slaves might escape and their owners have no recourse. If Texas 
were to be free, he believed that quarrels and even war would soon be the result. "If this government should make itself a party in asserting the rights of the slaveholder, the result could not fail to be unfavorable to Texas." With regard to her, the question would merely be whether a slave-owner would submit to intolerable and ruinous wrongs, or protect himself by force. "Between such alternatives, it is impossible to suppose that he would hesitate a moment." There was no analogy, he said, between Texas and Canada, for. between the slave states and the British province there were free states of the Union, bound to return the fugitive slave. Thus Murphy was told that the United States would not permit abolition in Texas. This is the prevailing idea of the instruction. It is equally noteworthy for what it omits, as there is not one word about the annexation of Texas. ${ }^{23}$ Murphy's answer was not received by Upshur until after annexation had been proposed to Van Zandt at Washington. Murphy was inclined to make light of Andrews and his abolitionist plans in Texas. "The people of Texas," he wrote, "love their constitution and form of government; and ninety-nine out of a hundred would die for their preservation. The constitution of Texas secures to the master the perpetual right to his slave and prohibits the introduction of slaves into Texas from any other quarter than the United States. Take this stand on the side of the constitution and the laws, and the civil, political, and religious liberties of the people of Texas (saying nothing about abolition) and all the world will be with you." ${ }^{24}$ Houston's apparent

${ }^{23}$ Upshur to Murphy, August 8, I843; ut sup.

${ }^{24}$ Murphy to Upshur, September 24, I843 (received November 3) ; H. Ex. Doc. 27I, 28 Cong., I Sess., 22. 
pro-British tendencies concerned Murphy more than Andrews's abolitionist schemes. He wrote: "Let the United States take some immediate quick step in this subject." ${ }^{25}$ Before Murphy's letter had been read by Upshur, the "quick step" had been taken. Murphy was told that as far as the government of the United States was concerned, it would come to the aid of Texas immediately if that were possible, but he feared that the government would not have the support of the people in the policy of assistance. "No negotiation is now pending between this government and Texas," he added. $^{25}$

Upshur, it will be seen, preferred to build up his policy upon the unofficial reports of Duff Green. Obviously, the proper source of information as to British interference in Texas was Everett, the minister to Great Britain; but Everett was not in touch with, nor was he in the confidence of, Tyler, who would gladly have got rid of him for Webster. From Everett's reports Upshur could gain nothing upon which to raise fears of British supremacy in Texas. Everett was then told that the movements of Great Britain relative to African slavery had assumed such a character as to demand the serious attention of the American government. Taking Brougham's interpellation of Aberdeen in the House of Lords, upon the general subject of Texas and slavery, as a peg upon which to hang an essay in defense of slavery as the necessary condition of the African race, Upshur repeated the

${ }^{25}$ Murphy to Upshur, September 23, 1843 (received Nov. 3) ; ibid., 24.

${ }^{26}$ Upshur to Murphy, September 22, I843. In part printed as above, but this quotation was omitted. 
arguments made to Murphy upon the danger of abolition in Texas." "A leading and fundamental institution, interwoven with the interests of nearly one-half of the States of our Union, is threatened by the policy of a foreign Power. We must be infatuated indeed, if we can quietly submit to any policy of a foreign nation designed or calculated to bring it into danger." ${ }^{28}$ Everett's report, if Upshur gave it any credit at all, must have shown the secretary that he had been deluded by a hoax, carefully prepared for him by Duff Green. Houston's and Jones's ruse of scaring the United States, played through Murphy in Texas and Van Zandt at Washington, was entirely successful. Everett's reply to Upshur stated that both Aberdeen and Ashbel Smith had distinctly denied that any proposition had been made by Texas in which abolition was mentioned. ${ }^{20}$

${ }^{27}$ Upshur to Everett, No. 61, September 28, 1843; S. Ex. Doc. 34I, 28 Cong., I Sess., 27.

${ }^{28}$ Upshur to Everett, confidential, September 28, I843; ibid., 37.

${ }^{20}$ Everett to Upshur, November I6, I843; ibid., 40.

"The subject of domestic slavery was never so much as mentioned or alluded to by the British minister to the government of Texas, except to disclaim in most emphatic terms any intention on the part of England to interfere with it here. Indeed, that constituted no part of the policy of that far reaching nation. She might be willing to tickle the abolitionists (a somewhat venomous but not very respectable or influential class of her citizens) but had no idea of going in a crusade with them to abolish slavery in Texas, or anywhere else. Her Texas policy was to build up a power independent of the United States who could raise cotton enough to supply the world; of which power slavery would be a necessary element. And this not primarily to injure the United States, but to benefit herself, not from enmity to Brother Jonathan, but love to John Bull, and so with France." Anson Jones, Official Correspondence, 82. 
But Upshur had been too powerfully played upon by fears of Great Britain to wait for Everett's report. What he had promised to do for Texas in general terms, was now put forth specifically. "Recent occurrences in Europe," he said, "have imparted to the subject a fresh interest and presented it in new and important aspects." He therefore proposed to Van Zandt that he ask for instructions favorable to a treaty of annexation. He could not guarantee the Senate's ratification of an annexation treaty, but he engaged that the President would urge the measure upon the "consideration of Congress." ${ }^{30}$

Van Zandt immediately asked for instructions to proceed according to Upshur's proposal. He wrote to his government that he hoped they would accept annexation, as he believed it the best move possible. "My secret opinion is that Santa Anna won't acknowledge our independence now, but we must keep tryingthe longer the armistice the better." " Upshur's overture came as a surprise to Houston. Murphy had not been instructed to offer annexation and he was not informed by Upshur of the proposal to Van Zandt. ${ }^{32}$ All that Upshur vouchsafed to say to Murphy was that the administration desired annexation but it was doubtful if it could be effected. ${ }^{33}$

${ }^{30}$ Upshur to Van Zandt, October 16,$1843 ;$ ibid., 37.

${ }^{31}$ Van Zandt to Jones, October 22, I843; Jones, Official Correspondence, 259

${ }^{32}$ Upshur to Murphy, January 16, 1844; S. Ex. Doc. 34I, 28 Cong., I Sess., 43. Upshur's letters to Murphy of October I8 and October 20 (MS., Archives) say nothing about annexation.

${ }^{33}$ Upshur to Murphy, November 2I, I843, was in reference to the armistice. Extracts printed in H. Ex. Doc. 27I, 28 Cong., I Sess., 43. 
In Houston's message to the Texan Congress in December, I843, he laid stress upon the friendliness of Great Britain and contrasted the efforts made by her to secure peace for Texas with the do-nothing and selfish policy of the United States. Soon afterwards Upshur's overture was received. Houston instructed Jones to decline the proposal for annexation." Thus the policy determined upon and carefully worked out, to force the United States to action through fears of British domination, was carried forward another step. Houston's declination of Upshur's overture was not counter to this policy but was strictly in accord with it. Annexation was refused because Upshur could not promise the ratification of the treaty. ${ }^{35}$ The Texan government was unwilling "to risk everything in a single throw of an uncertain die." Upon the receipt of Houston's refusal, Upshur bestirred himself upon the question of ratification. How much he depended upon definite promises from members of the Senate and how much upon hearsay it is impossible to state. He repeated to Murphy that "measures have been taken to ascertain the opinions and views of Senators upon the subject and it is found that a clear constitutional majority of two-thirds are in favor of the measure." This information Murphy gave to Houston. Relying upon the correctness of Upshur's statement (of which he doubtless had independent corroboration ${ }^{37}$ ), Hous-

${ }^{34} J o n e s ' s$ Memorandum, December 17, I843; Official Correspondence, 39 .

${ }^{35}$ Ibid., 261.

${ }^{30}$ Upshur to Murphy, January 16, 1844; H. Ex. Doc. 27I, 28 Cong., I Sess., 47.

${ }^{37}$ C. H. Raymond, Secretary of the Texan Legation at Washington, to Jones, February 17, 1844; Jones, Official Correspondence, $3 \mathrm{I} 4$. 
ton and his cabinet agreed to accept Upshur's proposal and to send a commission to the United States with full powers for the negotiation of a treaty of annexation. Houston, however, took the precaution to intrench himself against any unforeseen obstacle to the consummation of the treaty. He asked Murphy for a definite tender of protection on the part of the United States during the process of negotiation. ${ }^{38}$ Murphy assured Houston that the United States, having invited Texas to this negotiation, would at once, and before any negotiation was begun, place a sufficient naval force in the Gulf to protect the coast of Texas, and would hold a sufficient force of troops near the southwestern border of the United States in readiness to protect Texas pending the proposed negotiation for annexation. ${ }^{39}$

Van Zandt at Washington had made a similar request to Upshur for protection, ${ }^{40}$ but the secretary of state gave no answer to it. Houston was able to extract assurances from the incautious Murphy that Upshur, although enthusiastic for annexation, hesitated to give.

Feeling secure in the assurances that the treaty would be ratified and that the United States would protect Texas during the negotiation, Houston des-

${ }^{38}$ Murphy to Upshur, February 15, 1844; MS., Archives. Houston determined to send Henderson to Washington February I4. Jones said that guarantees were demanded because it was believed that no annexation treaty could pass the United States Senate. Official Correspondence, 38I. But this was written after the treaty had been rejected.

${ }^{39}$ Murphy to Upshur, February 15, 1844; H. Ex. Doc. 27I, 28 Cong., I Sess., 92.

${ }^{40}$ Van Zandt to Upshur, January I7, I844; ibid., 88. 
patched General J. P. Henderson to Washington to act in conjunction with Van Zandt for the accomplishment of annexation.

Before Houston's special commissioner arrived at Washington, Upshur, the active friend of annexation, and Gilmer, his strongest aide, with others of Tyler's closest friends, were no longer among the living. The Princeton tragedy, which threw the capital and nation into mourning, had a profound bearing upon the question of Texas so soon to be presented for final action. Another reconstruction of Tyler's cabinet was made necessary. Calhoun, the aggressive champion of slavery and but recently an avowed candidate for the presidency, was selected for the place of Upshur. By him was the negotiation conducted with Van Zandt and Henderson. The death of Upshur delayed the negotiation until the time for the national political conventions was almost at hand. Calhoun's abilities were exerted earnestly for the signing and ratification of the treaty. In no public matter of his life were his peculiar talents put to more strenuous use. Reasoning from his predilections with merciless logic, he robbed the question of Texan annexation of all its national advantages. He put it before the Senate and people of the United States as a sectional question, necessary to the salvation of the South and of its peculiar institution. Again was expansion halted and not furthered by slavery. The annexation treaty was rejected by the Senate. 


\section{CHAPTER VI}

Calhoun and the Attempted Annexation of TeXas by Treaty

There is a note of uncertainty in the proffer of the state portfolio by Tyler to Calhoun. After the death of Upshur, Tyler was in desperate straits. A new and untried man would not have been able to push forward the delicate negotiation which Upshur had been carrying on for the annexation of Texas. On the other hand, the appointment of a man like Calhoun, but recently an avowed aspirant for the presidency, might make the agent greater than the principal. The annexation of Texas, if accomplished, might be credited to Calhoun, and not to Tyler. The measure, if successful, might be the victory about which those Democrats, totally estranged from Van Buren, might rally.

The events of Calhoun's career immediately preceding his acceptance of Tyler's offer of the state department form a curious narrative of political intrigue. Calhoun had resigned from the Senate in 1842 and was immediately nominated for the presidency by the legislature of South Carolina. When the House of Representatives organized in December, 1843, Calhoun's friends agreed to support for speaker a northern Democrat, Wilkins of Pennsylvania. In return for this, memmers of the Pennsylvania delegation and others pledged their support to Calhoun as against Van Buren. The deal was discovered before the party contest took place. Ingersoll and Buchanan drove the Pennsylvania 
Democrats from this agreement and Wilkins was defeated in the caucus. ${ }^{1}$ Soon thereafter Calhoun announced to his friends his determination to issue an address formally withdrawing from the coming presidential contest. ${ }^{2}$ Calhoun's public expression upon the Texas question came at the same time." Gilmer, who had stirred up the Texas matter before, now appealed to Calhoun for his opinion as to annexation, possibly for the purpose of strengthening Upshur's hand in the Senate in favor of the treaty, with the ulterior purpose of drawing credit away from Tyler to Calhoun. Calhoun was told in strictest confidence that "negotiations had been commenced the object of which was to annex Texas to the Union." Gilmer stated that he was not at liberty to disclose, nor was he informed of, the precise state of the negotiation at present. "As a Candidate for public favor," he wrote, "I would not have you or any other to be committed upon this question in advance. I do not therefore approach you as one of those now in the public eye as candidates for the chief

${ }^{1}$ Rhett to Calhoun, December 8, I843; Report of Am. Hist. Association, I899, II., 898.

"Calhoun to Duff Green, February Io, I844; ibid., 568.

"Both of the great parties have degenerated from their original standard so far that they have ceased to represent their original principles. . . . The Democrats are the old Republican party turned spoilsmen."

${ }^{3}$ Writing to McDuffie, December 4, 1843, ibid., 555, Calhoun said: "I see the subject of Texas is destined to be one of the first magnitude. The interference there by Great Britain in order to act on our Southern institutions has presented it in a new and most important aspect,' and so changed it, that those who were formerly opposed to the annexation, may well support it now. I think no alternative is left us, and that if the Executive should take a stand for it, he ought to be unanimously and decidedly supported by the South." 
magistracy, but as an illustrious citizen whose opinions would derive no additional force from any station, as I believe they would not be influenced by a desire to obtain it." " Gilmer wrote from Washington and must have known how Calhoun's plans had miscarried in the Democratic caucus.

Calhoun had already learned from Virgil Maxcy (another victim of the Princeton disaster) the precise state of the Texas negotiation: "Mr. Upshur informs me-in the strictest confidence however except to you - that the terms of a treaty between him and the Texan Minister have already been agreed on and written out, and that the latter only waits for instructions from President Houston, which are expected in two or three weeks. . . . The President is resolved that he will communicate such a treaty to the Congress, and if the Minister has not firmness to sign he will adopt some other mode of bringing the mattter before Congress. Mr. Upshur is of opinion that this is the only matter that will take sufficient hold of the feelings of the South, to rally it on a southern candidate and weaken Clay and Van Buren so much there as to bring the election into the House, where the Southern States would not dare to vote for $\mathrm{Mr}$. V. B. and C. - .. The President has some hopes that he may become that Southern Candidate. But Mr. U. considers you as the only one that can be taken up and with a view to your availing yourself of the first moment, after the Executive communication to Congress on Texas, to place before the public your views on the question, that all who concur with you, may

4Gilmer to Calhoun, December 13, 1843; ibid., 904. 
at once rally upon you." " Thus in a confidential way Maxcy disclosed what a few days later Gilmer hinted at. If one may trust Maxcy's accuracy in reporting Upshur, the so-called "Calhoun intrigue" appears in a somewhat different light from that in which Benton placed it. That Calhoun's name was connected with Texas from the time Upshur succeeded Webster and the active Texas campaign began (as a part of a plan for furthering the South Carolinian's prospects for the presidency) cannot be shown. Indeed, Calhoun's determination to withdraw after the congressional caucus fiasco seems to argue against such a theory. But on the other hand it is plain that Calhoun's friends who were in the cabinet of Tyler were raising the Texas question to advance not Tyler but Calhoun. The devious paths of diplomacy are lost in the tangled maze of political intrigue. Upshur, with disloyalty to his chief, was engaged in pushing the Texas question in an effort to strengthen the prospects of Calhoun, who like Tyler courted political success in 1844 . Such intrigues explain Upshur's aggressiveness. Tyler, however, believed in his secretary's loyalty to him. As the course of events proved, Upshur's insincerity was never known to Tyler. The accident upon the Princeton lost two friends to Calhoun, as well as two members of the cabinet and active workers for annexation. Only four days before Upshur and Gilmer were killed, Huger, a senator from South Carolina, offered to resign his seat in Calhoun's favor, in order that his state might be represented again by her favorite son. Calhoun's reëntrance into public life was by another chan-

${ }^{5}$ Maxcy to Calhoun, December Io, I843; ibid., 903.

- Calhoun to Hammond, March 5, r844; ibid., 57 r. 
nel. On the reconstruction of the cabinet, the last of a series of such events in the administration of the unfortunate Tyler, Calhoun's friends were again active. Luckily Calhoun's withdrawal from the presidential contest had just been made public.

Tyler's biographer admits that the President did not want Calhoun in his cabinet, fearing, among other things, that the senatorial support which Upshur had gained for the ratification of a treaty of annexation might be lost if Calhoun took up Upshur's labors. Tyler accepted Calhoun, it was said, as a choice of evils. Indeed, it was asserted that it was not in respect to Texas at all, a negotiation which Upshur had "virtually closed," but on account of the Oregon question that President Tyler contemplated any good results from the appointment of Calhoun. This statement does not bear the test of investigation, for Tyler insisted to Calhoun that "the negotiation for Texas was in the act of competition ( $\mathrm{sic}$ ) e and would admit of no delay." ?

Tyler was drawn into the appointment of Calhoun by the importunities of Calhoun's friends, and those friends were not slow to claim credit for the appointment. ${ }^{8}$ He offered the state portfolio to Calhoun on the 6th of March after a "free and frank conversation with our friends, Governor McDuffie and Mr. Holmes of South Carolina." "We have reached a great crisis in the condition of public affairs," he wrote in making the offer, "which, I trust, will assume the place of a commanding epoch in our Country's history. The an-

'Tyler's Tylers, II., 294. Tyler to Calhoun, March 6, I844; Am. Hist. Association Report, I899, II., 939.

${ }^{8} \mathrm{Cf}$. Schouler's History, IV., 455. 
nexation of Texas to the Union, and the settlement of the Oregon question on a satisfactory basis, are the great ends to be accomplished. The first is in the act of competition and will admit of no delay. The last had but barely opened, when death snatched from me my lamented friend." Tyler did not wait to hear from Calhoun but sent his name without delay to the Senate, which confirmed the appointment immediately. Ten days later Calhoun accepted the appointment, stating to the President that he did so with great reluçtance. "Nothing short of the magnitude of the crisis, occasioned by the pending negotiations, could induce me to leave my retirement." His acceptance was conditional: when the negotiations were completed he should be at liberty to retire. ${ }^{10}$

Tyler's new secretary of state arrived in Washington late in March. The President had said nothing about annexation in his message to Congress in December, further than to make a decided statement that the war between Texas and Mexico must cease. But as has been seen, Calhoun already knew from reliable sources how far the Texan negotiation had been carried. Tyler was waiting for the Texas emissaries to arrive in Washington to frame a treaty upon the lines laid down by Upshur.

It will be remembered that Houston refused to send Henderson to Washington until Murphy had guaranteed that the forces of the United States would protect Texas pending the negotiation. Nelson, who was secretary of state ad interim until Calhoun arrived,

- Tyler to Calhoun, March 6, I844; ut sup.

${ }^{10}$ Calhoun to Tyler, March 16, 1844; ibid., 577. 
repudiated Murphy's guarantee to Houston. Murphy was told that he had allowed his zeal for annexation to carry him beyond the line of his instructions, thereby committing the President to measures for which he had no constitutional authority to stipulate." "The employment of the army or navy against a foreign power with which the United States are at peace is not within the competency of the President, and whilst he is not indisposed, as a measure of prudent precaution, and as preliminary to the proposed negotiation, to concentrate in the Gulf of Mexico, and on the southern borders of the United States, a naval and military force to be directed to the defence of the inhabitants and territory of Texas at a proper time, he cannot permit the authorities of that government or yourself to labor under the misapprehension that he has power to employ then at the period indicated by your stipulations." Although Tyler then knew that the armistice between Texas and Mexico had been broken, he professed to believe that hostilities would not be resumed and that "annexation would be speedily and peacefully accomplished." 12

The Texan commissioners, Van Zandt and Henderson, who now appeared in Washington, were not to be satisfied by such optimistic expressions. They insisted that guarantees in the line of those given by Murphy to Houston be renewed before further negotiation. Calhoun prevailed upon Tyler to make an about-face. The Texan commissioners were informed that orders had been issued to concentrate a strong naval force in the Gulf and to place troops upon the southwestern

${ }^{11}$ Nelson to Murphy, March II, I844; H. Ex. Doc. 27I, 28 Cong., I Sess., 95.

${ }^{12}$ Ibid. 
frontier to meet any emergency. After the treaty had been signed and while ratification by the Senate was pending, the President would deem it his duty to use all the means placed within his power by the Constitution to protect Texas from all foreign invasion. ${ }^{18}$ Prior to this assurance from Calhoun, Henderson wrote home that he had maintained a bold front upon the subject of his negotiation. Every one, even the British minister, knew the object of his mission and he made no secret of it. In conversation with members of both houses of Congress he found that all of the Whigs and some of the Democrats were anxious to postpone the subject until after the fall elections. "I have said that this is the third time that Texas has urged this measure upon the United States; that it is now brought up at the instance of the United States government, and that it cannot be postponed without finally and forever defeating it; that the situation of Texas is such that she must now seek safety in some quarter by annexation, alliance, or other engagements, which will secure her peace and immediate safety; that any delay at this time on the part of the United States will be fatal to her hope of annexing us in the future if she indulges in such hope." While some of the Democrats preferred delay because they were afraid of the political capital that Tyler or Calhoun might obtain from the measure, Henderson was assured by them that every Democratic senator would vote for the treaty, and he hoped for enough Clay-Whig votes to make up the necessary two-thirds. "Should the treaty be rejected, a bill will

${ }^{13}$ Calhoun to Van Zandt, April II, I844; ibid., 96. 
be ready to go before Congress to authorize the President of the United States to take possession of Texas, with our consent, as soon as it is expressed in a legal way."

Doubts as to ratification were already in the minds of Houston and his secretary of state. Houston's policy of scaring the United States into annexation by fear of British ascendancy in Texas was never abandoned, nor, on the other hand, did he at all relax his efforts to assure Texan independence upon the basis of stability and permanence in case the United States should again reject annexation.

The excitation of fears upon the part of the United States toward England, as a strong argument for annexation, and the use of every means by which the foundation of Texan independence might be laid, should annexation miscarry, were two parallel lines of one and the same policy. Houston's insistence that the United States guarantee protection pending negotiations was not so much for the purpose of defending Texas against Mexico as it was to force the hand of the United States as against Great Britain. ${ }^{25}$

After Murphy had withdrawn, in accordance with Nelson's instructions, his guarantees of naval and military aid, Jones remarked that the United States were recovering a little from their alarm. "I will have to give them another scare. One or two doses of English calomel and French quinine have to be administered, and the case will be pretty well out of danger." ${ }^{16}$

${ }^{14}$ Henderson to Jones, March 30, 1844 ; Jones, Official Correspondence, 334 .

${ }^{15}$ Murphy to Tyler, April 8, 1844; MS., Archives.

${ }^{16}$ Jones, Official Correspondence, 335. 
Elliott, the British chargé, returned to Texas from the United States and expressed his belief that no treaty of annexation would be ratified by the Senate of the United States. ${ }^{17}$ The close relationship of Elliott with Houston and Jones continued. Murphy again became alarmed at the prospect of British influence in Texas. He wrote to Tyler that Houston and his cabinet, as well as all of his leading confidential friends, were secretly opposed to annexation. "The number of British agents, crowding Galveston and Houston would astonish you. Secret, dark, and diligent in something or other, which men known or suspected to be friendly to annexation cannot find out." 18

At the time Murphy was thus writing to Tyler, Elliott was asking the Texan government for explanations as to its position toward his government, which had been active in attempting to put Texas at peace with Mexico. ${ }^{19}$ Elliott was told that the United States had done what other friendly nations had refused to do, namely, given a promise that Texas would be protected against invasion; that the proposition for annexation had been made by the United States; and for the sake of peace and security, Texas had accepted it. $^{20}$ Hearing that the French and British chargés had united in a protest against annexation, Murphy asked for a copy of the paper. Such a protest, if con-

${ }^{17} \mathrm{He}$ wrote this to Jones as early as February 22, 1844. Murphy to Upshur, February 22, I844; MS., Archives.

${ }^{18}$ Murphy to Tyler, March 10, I844; MS., Archives.

${ }^{19}$ Elliott to Jones, March 22, I844; Jones, Official Correspondence, 329.

${ }^{20}$ Elliott to Houston, March 8 and 22, 1844; Houston to Elliott, March 一, I844; Yoakum's Texas, II., 427. 
templated, was never made; for no more certain method of insuring annexation by the United States could have been adopted. However much Houston and Jones would have welcomed such a protest, the representatives of Great Britain and France were too wary to proceed as if in possession of a right which they manifestly did not have. ${ }^{21}$ Murphy was led to believe that a good understanding existed between Elliott and Houston. This much was true: Houston and Jones did nothing to estrange Elliott, who might be useful if annexation were defeated.

At Washington, Calhoun had little trouble in agreeing upon the terms of a treaty with Van Zandt and Henderson, after he had reversed Nelson's earlier decision and promised protection to Texas pending annexation by treaty. It had been claimed by Calhoun's correspondent that Upshur and Van Zandt had not only agreed upon the terms of the treaty in December, 1843, but that the agreement had been reduced to writing. This may have been the truth. No documentary evidence exists to prove or disprove it. At any rate Calhoun found little difficulty in bringing the Texan commissioners to an agreement, for the treaty was signed as soon as protection had been promised to Texas.

This annexation treaty was very brief. After reciting that the people of Texas had been, from the time of adopting their constitution, and still were, unanimous in their desire for annexation to the United States, it said that they had determined to accomplish this object

${ }^{21}$ Murphy to Jones, April 17, I844; Jones, Official Correspondence, 338 . 
so important to their permanent welfare. After formally ceding the sovereignty of the Republic of Texas, together with all its territory, it was stipulated that the "citizens of Texas should be incorporated into the Union and admitted, as soon as consistent with the provisions of the Federal Constitution, to the enjoyment of all the rights, privileges, and immunities of citizens of the United States." ${ }^{22}$ Thus a document promulgated by the exponent of the most extreme statesrights doctrines proceeded upon the theory that the Constitution did not extend ex proprio vigore to inhabitants of acquired territory, even though such inhabitants were citizens of a republic annexed to the United States. This treaty as drawn by Calhoun adopted the principle of constitutional law associated with the name of Chief Justice Marshall and first found in the case of the American Insurance Co. vs. Canter. ${ }^{23}$

The treaty further provided that all the public lands of Texas should be ceded to the federal government in consideration of the assumption by the United States of the national debt of Texas, amounting to ten millions of dollars.

Not a word was said about the boundaries of Texas. Van Zandt and Henderson had been instructed to stipulate that Texas might be divided into four states for admission into the Union, and further that the boundaries should be those already defined by the constitution and statutes of Texas. The former stipulation was obviously beyond the treaty-making power.

${ }^{22}$ S. Ex. Doc. 34I, 28 Cong., I Sess.

${ }^{23}$ Peters, U.S. Reports, I., 5II. Compare the terms of the Louisiana and Florida treaties. 
The second remained a matter for further adjustment. Van Zandt and Henderson could rest assured that if annexation became an accomplished fact the United States would make the most of the territorial claims of Texas.

The treaty was signed April I2. Not until the twenty-second did Tyler send it to the Senate with his message and certain documents in aid of the case for annexation. It must be remembered that Calhoun selected from the mass of correspondence upon the subject, heretofore reviewed, only those portions that were in accord with his theory, namely, that annexation was necessary to the salvation of the United States. because the peculiar institution of the South was endangered owing to the efforts of Great Britain looking toward abolition in Texas. That institution placed in jeopardy, the national interests of the Union were threatened. As a foundation for his case, Calhoun selected Upshur's letter to Murphy in which the sinister designs of Great Britain were discussed upon the information had from Duff Green, together with such extracts from Murphy's correspondence as might tend to add to the expressed fear of Great Britain's motives. In addition to this correspondence Calhoun added a letter of his own. If Upshur had sounded an alarm, Calhoun now exerted himself to raise the greatest possible excitement over the fancied menace. He did it by writing a letter to Pakenham, the British minister at Washington, but Calhoun directed it over Pakenham's shoulder to the American people. Never were the tools of diplomacy put to political use (always a dangerous practice) with more disastrous results than by Calhoun. The attempt to use a diplomatic com- 
munication as a political manifesto was a signal failure. The Senate refused to ratify the treaty. Again was slavery not the aid, but the obstacle, to expansion. Calhoun's correspondence with Pakenham did much to make it so.

Just prior to Upshur's death, Pakenham addressed a note to the secretary of state in which he enclosed a letter from Aberdeen, setting forth definitely and officially the attitude of Great Britain toward Texas. Aberdeen admitted that Great Britain took an interest in the welfare of the new republic and that she had put herself forward in pressing upon Mexico the claims of Texas for independence. He denied explicitly that Great Britain had any "occult design," either with reference to any peculiar influence over Mexico or Texas, or "even with reference to slavery in Texas." Had Aberdeen stopped there, the disarming of the American Anglophobes, north and south, would have been complete. He proceeded, however, to avow that he wished to see slavery abolished not only in Texas, but "throughout the world. But the means which she has adopted," he continued, "and will continue to adopt, for this humane and virtuous purpose, are open and undisguised. She will do nothing secretly or underhand. She desires that her motives may be generally understood, and her acts seen by all." Passing to the question of permanent influence in Texas, Aberdeen avowed that Great Britain's objects were purely commercial. "She has no thought or intention of seeking to act directly or indirectly, in a political sense, on the United States through Texas."

The final paragraph of the note was in questionable taste and unfortunate. It was outside the issues of the 
case to incorporate in an official letter to be handed to the representative of the federal government any reference to the free and slave states of the Union. The paragraph, though doubtless well-intentioned, was officious. "The British Government, as the United States well know, have never sought in any way to stir up disaffection or excitement of any kind in the slaveholding States of the American Union. Much as we should wish to see those States placed on the firm and solid footing which we conscientiously believe is to be attained by general freedom alone, we have never in our treatment of them made any difference between the slaveholding and the free States of the Union. Ail are, in our eyes, entitled, as component members of the Union, to equal political respect, favor, and forbearance on our part. To that wise and just policy we shall continue to adhere; and the Governments of the slaveholding States may be assured that, although we shall not desist from those open and honest efforts which we have constantly made for procuring the abolition of slavery throughout the world, we shall neither openly nor secretly resort to any measures which can tend to disturb their internal tranquillity, or thereby to affect the prosperity of the American Union." ${ }^{24}$

Upshur, of course, had no opportunity of answering Aberdeen's note. Not until after the Texas treaty had been signed did Calhoun reply. This letter of April I8, I844, is a most amazing piece of diplomatic literature, and all of Calhoun's aptitude for dialectics was brought into play at once. Nowhere did the man's

24 Pakenham to Upshur, February 26, I844, enclosing Aberdeen to Pakenham, December 26, I843. S. Ex. Doc. 34I, 28 Cong., I Sess., 48. 
logic carry him to a reductio ad absurdum more clearly than in this reply. Calhoun caught at certain phrases of Aberdeen's note and rang all the changes possible upon them. The President, he said, was glad to see that Great Britain had no intention of taking any measures to disturb the tranquillity of the slaveholding states of the Union. At the same time, he regarded "with deep concern the avowal, for the first time made to this government, that 'Great Britain desires and is constantly exerting herself to procure the general abolition of slavery throughout the world.' . . . So long as Great Britain confined her policy to the abolition of slavery in her own possessions and colonies, no other country had a right to complain.

But when she goes beyond, and avows it to be her settled policy, and the object of her constant exertions, to abolish it throughout the world, she makes it the duty of all other countries, whose safety or prosperity may be endangered by her policy, to adopt such measures as they may deem necessary for their protection." 25

The reply then outlines the history of the relations between the United States and Texas. While since her independence Texas had ardently wished for annexation to the United States, the United States had declined to meet her wishes. "The time has now arrived when they can no longer refuse, consistently with their own security and peace, and the sacred obligation imposed by their constitutional compact for mutual defense and protection."

Thus England's avowal of a desire for abolition throughout the world made it necessary by the obli-

${ }^{25}$ Calhoun to Pakenham, April 18, I844; ibid., 50. 
gations of the Constitution for the United States to annex Texas in order to defend the institution of slavery from future injury. Such a position really defies comment. It shows how far Calhoun's logic would carry him. The United States had remained passive as long as Great Britain's policy had no immediate bearing upon the peace and safety of the United States. It could remain so no longer. Calhoun next passed to the consideration of the general subject of abolition. He condemned it as hurtful to the white and degrading to the black. "It may safely be affirmed, that could she [Great Britain] succeed in accomplishing, in the United States, what she avows to be her desire and the object of her constant exertions to effect throughout the world, so far from being wise or humane, she would involve in the greatest calamity the whole country, and especially the race which it is the avowed object of her exertions to benefit." ${ }^{26}$

This letter of Calhoun's has been quoted at some length, for the importance of it in the consideration of the rejected treaty of annexation cannot be overestimated. Upshur had begun to take the same road, but his letters were not made public until Calhoun made use of them with the treaty. The reply to Pakenham, on the other hand, was written not only for publication, but with the purpose of creating an effect upon the American people. It was a call to arms for the slavery interests to unite against the aggressions of Great Britain, always hated, but now to be dreaded as the militant champion of abolition throughout the world.

${ }^{20}$ Calhoun to Pakenham, April I8, I844; ibid., 53. 
It attracted not, as he hoped, the slaveholding interests, but his own friends only. It repelled the southern Whigs and the northern Democrats. It pressed forward a new issue upon which the country was not yet prepared to take a stand.

Pakenham rejoined to Calhoun's reply the following day. ${ }^{27}$ Although in Tyler's hands when the treaty was communicated, it was not referred to the Senate for another ten days, and then with another reply from Calhoun. Pakenham insisted that Calhoun totally misconstrued Aberdeen's letter. Calhoun rejoined that no other construction could be given it than that the slave interests, now the national interests of the country, were menaced. At this point the correspondence ended. Its effect was, no doubt, quite different from what Aberdeen might have anticipated. It delayed annexation and all but robbed Calhoun of any part in the final success of the measure.

Tyler's message accompanying the treaty proceeded upon the lines of Upshur's and of Calhoun's correspondence, but the President softened the terms and tried to show annexation in its best light as a national question. He could not, however, neglect to remind the Senate of the danger of abolition in Texas, "which would operate most injuriously upon the United States and might most seriously threaten the existence of this happy Union. . . . The Executive saw Texas in a state of almost helpless exhaustion. The question was narrowed down to the simple proposition, whether the United States should accept the boon of annexation

${ }^{27}$ Pakenham to Calhoun, April 19, I844; Calhoun to Pakenham, April 27, 1844 ; ibid., 63, 65 . 
upon fair and even liberal terms, or by refusing it, force Texas to seek refuge in the arms of some other power. This might be either through a treaty of defensive and offensive alliance, or by the adoption of some other expedient, which might virtually make her tributary to a foreign power and dependent upon it for all future time. The Executive has full reason to believe that such would have been the result, without its interposition, and that such will be the result, in the event either of unnecessary delay in the ratification, or of the rejection of the proposed treaty." ${ }^{28}$ Such were Tyler's reasons for annexation and such were the predictions of the dire results to the nation if the Senate did not agree with him.

Another quarter remained to be heard from and that was Mexico. What would that nation do, after the United States had not only proposed annexation but had guaranteed to defend Texas during the pendency of the treaty? Calhoun instructed Green, the chargé at Mexico, to inform the Mexican government that a treaty of annexation between Texas and the United States had been signed and sent to the Senate; and that this had been done without any feelings of disrespect or of indifference to the honor or dignity of Mexico. "The step was forced upon the Government of the United States," he asserted, "in self defense, in consequence of the policy adopted by Great Britain in reference to the abolition of slavery in Texas. The Government has been compelled, by the necessity of the case, and a regard to its constitutional obligations,

${ }^{23}$ Tyler's message, April 22, I844; Richardson's Messages, IV., 307. 
to take the step it has, as the only certain and effectual means of preventing it." ${ }^{20}$ This note added to the weight which the already overburdened treaty had to bear. The position which the United States had rightfully taken was that Texas was independent de facto. Why, then, did Calhoun give Mexico an opportunity of discussing a question with which she had no legal concern? Texas had been recognized as independent not only by the United States but by several European powers. With the question of the future relations or status of Texas, therefore, Mexico had nothing to do. Tyler was already aware of Mexico's ultimatum on the subject of annexation. Before Upshur made his offer to Van Zandt he was in possession of Bocanegra's statement to Thompson, that "the passage of an act for the incorporation of Texas with the territory of the United States must be considered by Mexico as equivalent to a declaration of war." ${ }^{30}$

It was a strange position for Calhoun to assume that Mexico, which had already spoken upon the subject, would be appeased by the declaration that the United States accepted annexation as a necessity, made so by Great Britain's attitude toward abolition in Texas. Calhoun's position was the more censurable as the world knew that slavery did not exist in Mexico.

Weighted down by Calhoun's letters to Pakenham and Green, the treaty went to the Senate as a document already discredited. Tyler's name gave it no prestige. Calhoun's assistance drove from him even those elements upon which the President might have relied. The country was preparing for the quadrennial presi-

${ }^{20}$ Calhoun to Green, April 19, I844; S. Ex. Doc. 34I, 28 Cong., I Sess., 53.

${ }^{80}$ Bocanegra to Thompson, August 23, I843; ibid., 89. 
dential contest. By a strange coincidence, for it was probably nothing more, ${ }^{\text {s1 }}$ the two men, who hoped to be nominated for the presidency by their respective parties, came out upon the same day, late in April, in opposition to annexation. The position assumed by both Clay and Van Buren was in no sense surprising. Clay, however, had the support of his party. The Whig convention met soon after the letter appeared and Clay was the unanimous choice of the convention. Not so Van Buren. His star, which had been sinking ever since I84I (for after he left the presidential chair his support became less and less sincere), fell rapidly after the appearance of his letter upon Texas.

The Democratic convention was to meet during the last week in May. From the time Van Buren's letter appeared, the Texas treaty was not considered upon its merits, but as a basis for political manœuvering and intrigue. It must be borne in mind that the delegates in the national conventions of those days were chiefly the senators and representatives at Washington. The Whigs, north and south, would have nothing to do with a Tyler measure. The Democrats loyal to Van Buren were cautious. Those who would displace him feared the political capital which Tyler might gain if the treaty were ratified before the convention met. The forty votes for the treaty, which Upshur had claimed, ${ }^{32}$ dwindled to fifteen in the face of the presidential campaign. ${ }^{33}$

${ }^{31}$ Schouler, IV., 465, note.

${ }^{22}$ McDuffie to Calhoun, March 5, 1844; Report of Am. Hist. Association, I899, II., 934.

${ }^{33}$ Raymond to Jones, April 24, 1844 : "I have now scarcely any hope of its ratification but believe delay will strengthen the question." Jones, Official Correspondence, 343. 
A motion to make the treaty and the accompanying correspondence public came to a vote in the Senate ten days before the Democratic convention. The opponents of Tyler and Calhoun showed their strength. By a vote of twenty-six to seventeen the Senate gave Calhoun's and Upshur's pro-slavery manifestoes to the country. Of the seventeen who voted against putting the treaty before the people was one Whig, Archer of Virginia, the friend of Tyler. Of the Democrats ten were from the South, six from the North. Even Calhoun had not succeeded in making the question of Texas a sectional question.

The correspondence given publicity, no action was taken upon the treaty until after the Democratic convention had adjourned. Polk was taken up by Van Buren's friends in order to defeat Cass. ${ }^{34}$ "The immediate reannexation of Texas" was adopted as the Democratic war-cry. It was indeed a cry to rally the South, but not around Tyler, nor indeed around Tyler's Mephistophelian attendant, Calhoun.

The Democratic convention adjourned and the senators returned to Washington to resume consideration of Tyler's treaty. Immediate reannexation of Texas they were agreed upon, but according to the methods dictated by the Democratic party, not under the leadership of a president who stood alone. Seven days after the convention adjourned the Senate rejected the treaty by a vote of thirty-six to fifteen. Murphy, who had been Tyler's too zealous agent in Texas, was also condemned by the Senate, which refused to confirm his

${ }^{34}$ "Letters from Pillow to Polk," American Historical Review, July, 1906. 
appointment. "The treaty," Murphy wrote to Houston, "is rejected and so is my nomination. The tail went with the hide." ${ }^{35}$

So ended the negotiation for Texas by treaty. Against his own will Tyler had made annexation a party question. Houston wrote to Jackson, when Henderson was sent to Washington, that Texas was presented to the United States as a bride adorned for her espousals. "If in the confident hope of the union she should be rejected, her mortification would be indescribable. She has been sought by the United States, and this is the third time she has consented. Were she now to be spurned, it would forever terminate expectation on her part; and it would then not only be left for the United States to expect that she would seek some other friend, but all Christendom would justify her in a course dictated by necessity and sanctioned by wisdom. However adverse this might be to the wishes or the interests of the United States, she could not ponder long."

With the rejection of the treaty, an outcome which Houston had anticipated, the president of Texas, whether actuated by sincere motives or not, planned for the permanent and secure independence of his country. Again he turned to Great Britain. On the other hand Tyler determined to do what had been suggested when annexation was first discussed. Two days after the Senate refused to ratify the treaty he announced his determination to force annexation by joint resolution. "The great question is," he informed the

${ }^{35}$ Murphy to Houston, July 3, I844; Yoakum, Texas, II., 432.

${ }^{36}$ Houston to Jackson, February 16, 1844; H. Ex. Doc. 271 , 28 Cong., I Sess., iro. 
House, "not as to the manner in which it shall be done, but whether it shall be accomplished or not." ${ }^{37}$

${ }^{37}$ Tyler's message, June II, I844, and correspondence accompanying it; ibid. 


\section{CHAP'TER VII}

The Annexation of Texas by Joint Resolution I $844^{-1} 845$

When the treaty was rejected, Calhoun, who had staked all upon the issue of the defense of slavery against the menace of Great Britain's abolitionist influence, felt that annexation was a lost cause. Though he said that the United States had reluctantly taken a position favorable to annexation because it was seen that not only the interests of the nation but the Union itself depended upon it, he now professed to believe that Texas was forever lost to the United States. ${ }^{1}$

Calhoun's dejection was, however, of short duration. Tyler determined upon an appeal to the House over the head of the Senate. Calhoun was given to understand that unless he actively coöperated with Tyler, his resignation would be in order. ${ }^{2}$ Henceforth Calhoun pursued the subject with inflexible determination, afterwards claiming the credit of annexation." How much Tyler was influenced in his persistence by a desire to go before the country as a candidate for the presidency upon a platform of "Tyler and Texas" cannot be definitely stated. A handful of officeholders and personal friends had met in convention in Baltimore and nominated Tyler for the presidency,

${ }^{1}$ Tyler's Tylers, II., 33I.

${ }^{2}$ Ibid.

${ }^{3}$ Calhoun's speech in the Senate, February 24, I847; Works, IV., 362 . 
but the act of the so-called convention excited only derision. Tyler accepted the farcical nomination in a letter in which he put forward his claims to the public confidence. Upon the subject of Texas he was outspoken: "If annexation is to be accomplished, it must be done immediately. . . . The question with me is between Texas and the presidency. The latter, even if within my grasp, would not for a moment be permitted to stand in the way of the first."

The presidency was plainly far from being within Tyler's grasp. The regular Democratic convention, which had nominated Polk and Dallas, declared for the "reannexation" of Texas and the "reoccupation" of Oregon. If Tyler was to be an agent for annexation he must be such during the nine months of his unexpired term. Threats of impeachment, for having given orders to the army and navy to protect Texas pending the consideration of the treaty, did not deter the President from appealing beyond the treaty-making power.

It has been seen that annexation by act of Congress instead of by treaty had been suggested almost as soon as Texas was recognized. During the negotiation that resulted in Calhoun's treaty the project of annexing Texas by act of Congress (under that provision of the Constitution which gave Congress power to admit new states) had been put before the people by R. J. Walker, a senator from Mississippi. When it was definitely seen that the treaty would fail, McDuffie, a close friend of Calhoun, introduced a resolution into the Senate along the line of Walker's suggestion. ${ }^{5}$

“ Tyler's Tylers, II., $32 \mathrm{I}$.

'Ibid., II., 33I. 
The first session of the twenty-eighth Congress was nearing its close. As is usual in presidential years, Congress was disinclined to put itself on record upon any question after the presidential conventions had met, nominated, and adjourned. Tyler, however, was not willing to let the matter of Texas rest until Congress met in regular session the following December. By that time the presidential contest would be decided. Tyler sent a message to the lower house recommending the passage of an act annexing Texas. Writing to Howard, the American chargé in Texas, he promised to call a special session for the purpose of pushing annexation through before the fall elections." In his message to the House Tyler said that the power of Congress was "fully competent in some other form of proceeding to accomplish everything that a formal ratification of the treaty could have accomplished. . . . While I have regarded the annexation to be accomplished by treaty to be the most suitable form in which it could be effected, should Congress deem it proper to resort to any other expedient compatible with the Constitution, and likely to accomplish the object, I stand prepared to yield my most prompt and active coöperation. The great question is, not as to the manner in which it shall be done, but whether it shall be accomplished or not. The responsibility of deciding this question is now devolved upon you."

Congress adjourned a week after Tyler sent his message to the House. Just prior to adjournment Tyler was

- Tyler and Calhoun to Howard, June I8, I844; MS., Archives.

${ }^{2}$ Message of Tyler, June Io, I844, with correspondence; H. Ex. Doc. 27I, 28 Cong., I Sess. 
assured in writing by prominent Democrats in the House that the subject of annexation should not be permitted to rest. ${ }^{8}$ The campaign for annexation by act of Congress was launched even before Congress adjourned.'

Murphy's nomination as chargé to Texas had been rejected; Tyler then appointed General Tilghman A. Howard of Indiana. Howard was originally from Tennessee and a friend of Jackson. But more important in the present case, he was a friend of the distrusted Houston. When Houston was governor of Tennessee, Howard was in close official relationship with him. ${ }^{10}$ The new chargé left Washington for Texas with some evidence that annexation was not finally defeated. The pledge of congressmen to support annexation, which Tyler had, was accompanied by a memorandum from Calhoun setting forth the aid that might be counted upon in the Senate. Calhoun believed the Senate committee upon foreign affairs would stand five to four for annexation and that fourteen Whig senators from the slave states, of whom all but one had voted against the treaty, would favor annexation by act of Congress. ${ }^{11}$

The necessity for such assurances was plain. Howard would have been in a most uncomfortable position if he had been forced to urge Texas to stand firm for

'Tyler to Howard, June 18, 1844; MS., Archives, C. H. Raymond to Jones, June 5, 1844; Jones, Official Correspondence, 360 .

'The votes upon Tyler's message were: to lay upon the table, for, 66; against, II8; to suspend the rules and print, for, in8; against, 79 .

${ }^{10}$ Henderson to Jones, June 2, 1844 ; Jones, Official Correspondence, 356 .

« T. A. Howard's memorandum; MS., Archives. 
annexation after the United States had refused to confirm its own offer. It was Howard's duty to impress upon Houston's government that annexation would be accomplished without delay. Calhoun felt no doubt of the continued desire of the people of Texas for annexation, but he feared that there might be a revulsion of feeling there on account of the rejection of the treaty, and that this might be played upon by those who were unfriendly to the United States. "The danger is that the revulsion of disappointed hopes highly excited may be seized upon by an interested and wily diplomacy and made the means of seducing them to seek and form another alliance with the Power, which, there is reason to fear, has been eagerly watching the favorable opportunity." ${ }^{12}$

Shortly before the Senate finally rejected the treaty, Rives of Virginia introduced a resolution laying the treaty upon the table and asking the President to cause an additional article to be negotiated, extending the period of ratification, so as to give further time for a full and deliberate expression of an opinion by the American people on the subject and also for a reasonable and amicable effort to obtain the concurrence of Mexico in a "constitutional arrangement for ascertaining and establishing the boundaries between that country and Texas." Nothing came of the resolution. Tyler was known to be opposed to delay. Henderson, one of the Texas commissioners, objected to it upon the ground that he had no authority to consent to any such measure. He felt sure that Houston would regard postponement as equivalent to rejec-

${ }^{12}$ Calhoun to Howard, June I8, I844; MS., Archives. 
tion. ${ }^{13}$ When the news of the Senate's failure to ratify was had, Houston, without consulting his secretary of state, wrote directly to Henderson and Van Zandt ordering them home immediately. ${ }^{14}$

Jones, Houston's secretary of state, was a candidate for the presidency of Texas, for which an election was to be held in the following September. Between Jones and Houston had arisen a feeling of jealousy, which afterwards grew into open enmity. Each accused the other of being secretly opposed to annexation. How far Houston's determination to scare the United States into annexation carried him along into opposition to annexation one can hardly determine. In the days immediately following the rejection Houston appeared to be the opponent of annexation. The rejection of the treaty he could fairly claim to be the end of all hopes of union. Tyler and his cabinet, although fearing that Houston had followed them as far as his dignity would permit, now endeavored to hold the president of Texas firm to annexation by sending one of Houston's old friends and an admirer of Jackson as chargé.

Jones, on the other hand, believed that delay would not defeat annexation. He proceeded upon the theory that Texas must have peace, and this might be had either by annexation, in which case the United States would relieve Texas of responsibility, or by Mexico's recognition of Texan independence. Jones's policy was eminently one of statesmanship. $\mathrm{He}$ was accused of

${ }^{13}$ Resolution of June 6 , 1844 , in secret session; Henderson to Jones, June 7, I844; Jones, Official Correspondence, 364 .

${ }^{14}$ Houston to Jones, July 8, I844; Jones, Official Correspondence, $37 \mathrm{I}$. 
being an opponent of union with the United States, but the accusation was unjust. Although favorable to annexation, he proceeded upon the theory that if annexation were impossible (a question which the pending political contest in the United States would soon decide), Texas could pursue her own course without any fear of Mexican invasion or menace. While waiting for the decision of the people of the United States, his efforts were directed toward the establishment of peace with, and independence of, Mexico. During the summer of I 844 Houston seemed to be impressed with the idea that annexation was an impossibility; Jones thought delay would not injure the cause of annexation, but in the event of the final defeat of annexation his country must be upon a footing of assured peace. Houston's position seems to have been one of emotion, of disappointment and despair, based upon the rejection of the treaty. Jones's position was one of calculating shrewdness, which was founded upon a genuine desire for the welfare of Texas.

The Texan government did not wait long for a renewal of Calhoun's assurances of protection pending annexation. The armistice between Texas and Mexico having expired, Woll, commanding the Mexican army at Mier, gave notice to Houston that hostilities would be renewed..$^{15}$ Howard, the new chargé, was informed of Woll's intentions and requested "to take the necessary steps to carry into effect the assurances (already given) and to extend to Texas the aid which the emergency required." 16

${ }^{15}$ Woll to Houston, June 19, I844; H. Ex. Doc. 2, 28 Cong., 2 Sess., 27.

${ }^{16}$ Jones to Howard, August 6, I844; ibid., 25. 
Howard's answer, which Jones characterized as hair-splitting, was that the assurances of protection extended only during the pendency of the treaty, and that he had no instructions beyond that. ${ }^{17}$ Tyler decided that the obligation to protect Texas extended not merely during the consideration of the treaty, but also while the question of annexation was pending. Such a position was a dangerous one. "As far as it relates to the executive department he (the President) is prepared to use all its powers for that purpose. But the government of Texas is fully aware that they are circumscribed by the constitution within narrow limits, which it would not be possible for the President to transcend. All that he can do is to make suitable representations to the Mexican government against the renewal of the war pending the question of annexation, and the savage manner in which it is proposed to conduct it, and to recommend to Congress to adopt measures to repel any attack which may be made." 18 After all of Tyler's brave talk of protection, he fell back to the position that Webster had taken: to remonstrate with Mexico against the continuance of the war. Active measures of protection were admitted to be within the power of Congress only. Wilson Shannon of Ohio, who had been tendered and had accepted the position of minister to Mexico some months before, ${ }^{10}$ was told to protest against the renewal of the war. Calhoun wrote that Mexico's object was plain: "To defeat the annexation of Texas to the United States and probably to drive Texas into political connections

${ }^{17}$ Howard to Jones, August 6, 1844; ibid., 28.

${ }^{18}$ Calhoun to Howard, September 10, 1844; ibid., 50.

${ }^{10}$ Shannon to Calhoun, April 17, 1844; MS., Archives. 
with some other power less congenial to her feelings and favorable to her independence, and more threatening to her and our permanent welfare and safety." The President, therefore, would use all his constitutional powers to stop the projected renewal of war. "If Mexico has thought proper to take offense [at annexation] it is we, who invited a renewal of the proposition, and not she [Texas] which accepted it, that ought to be held responsible. . . . Mexico would make a great mistake if she should suppose that the President would regard with indifference the renewal of the war." ${ }^{20}$

Shannon replied that although efforts were making to increase the army and to rebuild the navy in consequence of the belligerent utterances of Santa Anna, he believed that the projected invasion for the subjugation of Texas would come to nothing. Santa Anna and the Mexican congress were mutually antagonistic. If the congress voted means to support an army, it would result in the prolongation of Santa Anna's power. If the congress controlled the army as well as the funds, Santa Anna would be driven out. The belligerent manifesto Shannon believed to be brutum fulmen. ${ }^{21}$

Raymond, who continued to look after the interests of Texas at Washington after the departure of Van Zandt and Henderson, wrote to Jones: "Mr. Calhoun informed me on yesterday that Gen. Howard would have been instructed to renew the assurance given to our government in April last, relative to the disposi-

${ }^{20}$ Calhoun to Shannon, September 10, 1844;H. Ex. Doc. 2, 28 Cong., I Sess., 29.

${ }^{21}$ Shannon to Calhoun, October 28, I844; MS., Archives. 
tion of the army and navy of the United States for our protection during the pendency of annexation; and that in his despatch to Gen. Howard, he had so directed him; but when it came to be submitted to the Cabinet, the gentlemen at the head of the war and navy departments preferred its being omitted, in order that the return of the naval force to the Gulf and Coast of Texas, which they had only left on account of the equinoctial storms, should seem as a mere continuation (as it was in fact) of the April orders, which had already stood the test of the most rigid scrutiny of Congress. I was assured that a continuation of these orders had been made and that these vessels of war would be on the spot before any danger could approach us. I believe this government will do rather more for our protection and support, if necessary, than they desire should appear. They don't like to leave themselves open to an attack by Congress, especially Wilkins, Mason and Nelson. Mr. Calhoun is casehardened. When he thinks he is right he will go ahead, no matter how great the responsibility; and had he the power, the army would doubtless be ordered right into Texas to repel any attack upon her." ${ }^{23}$

Tyler and Calhoun were more afraid of the action of other powers than of Mexico. It was understood that the British interests in Mexico had represented to Santa Anna that the independence of "Texas would be of advantage to Mexico in creating a buffer state against the aggressions of the northern republic. In June, after the rejection of the treaty, Aberdeen

${ }^{22}$ Raymond to Jones, September 13, I844; Jones, Official Correspondence, 382 . 
proposed to Ashbel Smith, who continued to represent Texas in Great Britain and France, that Texas join in a diplomatic act with Great Britain, France, the United States, and Mexico: "The basis of the proposed diplomatic act was peace between Texas and Mexico, and the permanent separate independence of Texas-the parties to the act to be its guarantors." ${ }^{2 s}$ Aberdeen further told Smith that while the United States would be invited to join with the other powers, it was not to be expected that it would accept. "It was believed Mexico would participate, but in case of her refusal, England, France, and Texas having passed the act as between themselves, Mexico would be forced to abide its time. The act if passed by the three powers would not be abandoned-it would be maintained." Smith asserted that he and Aberdeen agreed definitely upon the terms of the arrangement. "The two European powers asked no privileges, hinted at none, did not propose to touch directly or indirectly, made no allusion even, to any institutions of Texas, or to its domestic or foreign policy outside the express terms of the act. Those were limited absolutely to the objects on the face of it; peace and permanent independence." ${ }^{24}$ The assent of France Smith claimed to have definitely obtained. On the other hand, Wise, Tyler's minister at the Court of Louis Philippe, reported to Calhoun that there was no truth in the report connecting France with Great Britain in an effort to persuade Texas to withdraw the proposition

${ }^{23}$ Ashbel Smith, Reminiscences, 6r. Smith was opposed to the "diplomatic act." Worley in Quarterly of the Texas State Historical Association, IX., 32.

${ }^{24}$ Ibid. 
to annex on condition that Mexico should be made to acknowledge her independence. King, however, did not obtain from Guizot any definite assurance that France would not join in obtaining Mexico's recognition of Texan independence. Calhoun authorized King to state to the French government that if action were taken looking toward the recognition of Texas by Mexico as a means of assistance to Mexico against the United States, it was a mistaken policy because the United States had no disposition to aggrandize itself at the expense of Mexico. "The fact is the very reverse." Calhoun then dwelt upon the dissimilarity of interests between France and Great Britain. The latter had political, the former merely commercial, motives in treating for Texan independence. But France must know that her commercial interests were not in harmony with those of Great Britain, who plainly aimed to monopolize all markets. France could be sure of having fair treatment from the United States, and as for her commercial interests with Texas, they would be improved if annexation took place. She could then purchase cheaply the produce raised by slave labor. If Texas were free and independent, France would have to pay more dearly for all products such as Texas raised. King was instructed to urge France not to join Great Britain in her mistaken propaganda for abolition. Calhoun then described abolition as a crime against civilization. "It would be to substitute for the existing relation a deadly strife between the two races, to end in the subjection, expulsion, or extirpation of one or the other; and such would be the case over the greater part of this continent where negro slavery exists. It would not end there, but would in all prob- 
ability extend, by its example, the war of races all over South America, including Mexico, and extending to the Indian as well as to the African race, and make the whole one scene of blood and devastation. Dismissing, then, the stale and unfounded plea of philanthropy, can it be that France and the other great continental powers-seeing what must be the result of the policy, for the accomplishment of which England is constantly exerting herself, and that the defeat of the annexation of Texas is so important toward its consummation-are prepared to back or countenance her in her efforts to effect either ?" ${ }^{25}$ In his defense to Pakenham, Calhoun had taken the ground that annexation was necessary for the perpetuation of the Union, which abolition menaced. Now he claimed that unless annexation took place, a war of races would drench all America in blood. France was asked to choose the state of things which annexation would offer: low prices for the products of slave labor, instead of high prices, for which England was working; to prefer peace, the outcome of annexation, to Texan independence and the horrors of a race war.

It is hard to comprehend that such a position was ever assumed by any American secretary of state. Had Calhoun stated (and this was the traditional doctrine) that Great Britain and France must keep hands off Texas, he would have remained upon safe ground. He could not, however, say this as long as the United States had determined not to permit Texas to remain independent. To draw France away from England

${ }^{25}$ Calhoun to King, August I2, I844;H. Ex. Doc. 2,28 Cong., 2 Sess., 44. 
upon the Texas question was obviously necessary. If Great Britain and France had jointly guaranteed the independence of Texas with the condition that that independence should be permanent, the United States would have been drawn into a war, provided (and this was unlikely) the people of Texas ratified such an arrangement. Had the United States been told by Great Britain and France that Texas should not be annexed, war would have been necessary in order that the United States should vindicate its position. If Texas had bound herself to Great Britain and France to remain independent, Tyler would have been in the predicament of having placed before the American people an issue which two European powers forbade it to decide. Houston resolved that Texas should bind itself by just that promise.

In September occurred the contest for the Texan presidency. Jones, Houston's secretary of state, was elected. The date set for his inauguration was not until December. Houston ordered Jones to instruct Smith to conclude the diplomatic act upon the terms proposed by Aberdeen. Houston's order to Jones was as follows: "Let dispatches be forthwith sent to Dr. Smith, to the care of Mr. Rate ${ }^{27}$ at London. Let the instructions be given Mr. Rate to forward said dispatches, in the event of Dr. Smith's departure homeward, to Colonel Daingerfield, at the Hague. Let full powers and letters of credence be also transmitted to Colonel Daingerfield, to be used by him in the event

${ }^{26}$ Houston to Jones, September 23, I844; Niles' Register, LXXIV., 4I3.

${ }^{27} \mathrm{Mr}$. Lachlin McIntosh Rate, a London merchant, and at the same time an agent of the government of Texas. 
of Dr. Smith's leaving Europe, in conducting the necessary negotiations with the Courts of England and France. Let our representatives (Dr. Smith or Colonel Daingerfield) be instructed to complete the proposed agreement for the settlement of our Mexican difficulties, as soon as possible-giving the necessary pledges, as suggested in the late dispatch of Dr. Smith on this subject, but adhering to the Rio Grande as a boundary, sine qua non. Also let our representatives be instructed at once to enter into the proper arrangements, for the admission of our products into the ports of England, (and France if possible), upon the most favorable terms-suggesting to the European parties that now is the most favorable time for such an arrangement with this country, in consequence of the absence of the obstacles which a treaty with the United States might interpose."

Jones, the secretary of state, relying upon his position as president elect, disobeyed Houston's orders and failed to issue the instructions. ${ }^{23}$ Smith returned to Texas believing that Guizot had been impressed by King with the idea that any action on the part of France toward Texas would give umbrage to the United States. ${ }^{20}$ Aberdeen, on the other hand, he thought, still relied upon the coöperation of France and would act provided Texas gave satisfactory assurances of its determination to remain independent.

By the time Smith had reached Texas and become secretary of state under Jones, the elections in the United States had been won for Polk. Thanks to the

${ }^{23}$ Jones, Official Correspondence, 43.

${ }^{29}$ Smith to Jones, December 24, 1844; ibid. 
Liberty party in the state of New York, the annexation of Texas seemed to have been endorsed by a popular vote.

Tyler's message to Congress in December, I844, was a call for action based upon the vote of the people upon annexation. "Instructions have come up to both branches of Congress from their constituents in terms the most emphatic. It is the will both of the people and the States that Texas shall be annexed to the Union promptly and immediately." so All of the arguments heard in the treaty-message of the past May were again brought forward. As far as the wishes of Texas were concerned, he believed there had been no change. As for Mexico's threat of war, it should have no effect upon the action of the United States, for Mexico had no rightful concern in the ultimate destiny of a republic which was de facto independent of her. As for other nations, Tyler stated that he apprehended no serious complaint from them. "No sufficient ground exists for such complaint. We should interfere in no respect with the rights of any other nation. There cannot be gathered from the act any design on our part to do so with their possessions on this continent. We have interposed no impediments in the way of such acquisitions of territory, large and extensive as many of them are, as the leading powers of Europe have made from time to time in every part of the world. We seek no conquest made by war. No intrigue will have been resorted to or acts of diplomacy essayed to accomplish the annexation of Texas. Free

${ }^{30}$ Tyler's Annual Message, December 3, I844; Richardson's Messages, IV., 344. 
and independent herself, she asks to be received into our Union. It is a question for our own decision whether she shall be received or not."

In all this there is an absence of the futile assertion of Calhoun that the United States reluctantly turned to annexation because forced to do so by the intrigues of Great Britain for abolition in Texas. Tyler dropped the pro-slavery argument and stood upon the question of national right, a position thoroughly tenable. His reference to the possessions of European powers in America was not only conciliatory, it was milder than the facts warranted. Calhoun, however, still feared that Great Britain would. "consummate her grand scheme of commercial monopoly, disguised under the garb of abolition."

General Howard, the friend of Houston and Jackson, died in Texas in August. Tyler offered the position of chargé to Andrew Jackson Donelson, the sonin-law and former private secretary of Jackson, who had taken a prominent part in the successful manœuvers that won the presidential nomination for Polk. This appointment was designedly made to bring to bear the personal influence of Jackson upon Houston. ${ }^{32}$

${ }^{31}$ Calhoun to" King, December 13, 1844; Report Am. Hist. Association, I899, II., 632.

${ }^{32}$ Calhoun to Donelson, September 15, I844; ibid., 6r4. Jackson to Van Buren, October 22, I844; MS., Van Buren Papers, Library of Congress:

"Hermitage

"My dear Sir,

Octbr $22^{\text {nd }} 1844$

"Major A. J. Donelson left me yesterday for Texas, as charge de affairs, to fill the vacancy occasioned by the lamented death of Genl Howard-The Major accepted this appointment by the great solicitude of the Government 
Duff Green, who had been such a willing instrument for annexation under Upshur, was sent to Galveston as consul with a further duty as bearer of despatches

$\&$ his political friends, and at a great sacrifice of his private interest-but such is the great national importance of Texas to the whole Union, and to the safety of the South \& West, \& the great interest of this Union so considered by all the democrats-that public duty prevailed over his private interest, \& he has accepted the mission.

"The Major has fully exposed to me his private meansThey are ample to meet all his pecuniary engagements and to make his family comfortable \& independent as I believe. The Major requested me to say to you, that as he passed thro' Neworleans, he would make arrangements, based upon his cotton crop, to remit to his N. York debt six thousand dollars, which thro his present crop of cotton, thinks that he can do-His crop in Mississippi, is promising \& he has a fair crop here, and if cotton commands seven cents, I have no doubt thro the commission Merchants, he will be able to comply with what he has authorized me to say to you-at least I hope he may.

"I have had a Hemorhage a few days ago-I am very feeble, \& have been visitted with a chill-The lancet to meet the first, and medicine to meet the last which has very much enfeeble [d] me-I am still able to set up \& wield the pen, but with great difficulty.

"You see we have lost the election in Ohio-still I hope she may rally and on the first of Novbr regain her democracy-We are in good spirits here of your empire state that she is, \& will prove sound to the core for democracy-But the Whiggs from corruption, fraud, and pipe laying claim that they will carry New York this their bost here- Please, on the receipt of this give me your opinion of the result. Georgia is safe for the Democracy-Polk \& Dallas I think will carry Tennessee, and the Democracy of Kentucky are of the opinion they will carry that state. Our friend Col Benton has got himself in hotwater in Missouri I hope he may be able to regain his former high standing with the democracy of the West-I hope he may be again electedshould he fail, he will be politically lost to the democracyIn confidence, I can say to you, that the leading democrats 
to Mexico. ${ }^{38}$ Just what Green's duties were does not appear, but he was sent doubtless to aid in strengthening the desire of the people for annexation, even to the extent, in the opinion of Jones, of fomenting a revolution in Texas if the government of Texas openly favored separate independence. ${ }^{34}$

Donelson reported the conversations had with Houston and Jones and his conclusion therefrom that the retiring and incoming executives of Texas were in favor of annexation notwithstanding all contrary reports. Terrell, a well-known advocate of independence, had been sent as minister to England and France. Donelson feared that this was an indication of the change in the policy of Texas. Houston tried to disabuse his mind upon this point. "Terrell," Houston said, "was not authorized to conclude a treaty, that he had sent him to England and France to see what bids they would make, what boot they would give-that he was not authorized to commit the gov-

of both Illinois \& Indiana, advise me, that his speeches on the Texan question has been by thousand published by the Whiggs \& circulated to the great injury of the democratic cause, and some of his best friends in Ohio have complained of this, and has confidently assured me, that the Col speeches, and the apathy of Allen \& Tapan on the Texan question has lost Ohio to the democrats-but that they will make another struggle on the first of novbr next.

"My whole Household Join me in kind salutations to you \& yours, as does Major Donelsons family, and particularly yr little god daughter, Mary-very respectfully"

[Signature cut off]

${ }^{33}$ Calhoun to Tyler, February I0, 1845; Report Am. Hist. Assoc., 1899, II., 643. Shannon to Calhoun, November I2, I844; MS., Archives.

${ }^{34}$ Officers of the Government of Texas to Jones, December 30, 1844; Jones, Official Correspondence, 412. 
ernment, and power to do so would not be given to him." ss Again is the question of Houston's sincerity raised. Donelson believed he had in him, as well as in Jones, a true friend. Jones, whose enmity to Houston soon became no secret, claimed that Houston opposed annexation from the time the Calhoun treaty was rejected. The question, however, is not important. Jones, not Houston, was to occupy the center of the Texan stage after the ninth of December.

The new chargé to Texas emphasized the necessity of haste on the part of Congress. "Every day's delay is adding strength to the hands of those who are playing the game for the ascendency of British infuence in this Republic. Delay will increase the difficulties already in our way, if it does not make them insurmountable." ss He reported that Houston assured him that he would be proud to see annexation accomplished during Donelson's residence in Texas. ${ }^{37}$

In his valedictory message to the Texan congress, however, Houston did not give utterance to those proannexation views with which he had raised Donelson's hopes. He dwelt upon the splendid prospects which Texas would have if she persevered in separate independence, and drew attention to the friendly attitude of European nations in contrast with the manifest coolness of the United States. Jones's inaugural contained not a word upon the subject of annexation. ${ }^{3 s}$

${ }^{35}$ Donelson to Calhoun, November 24, I844; Report by A. C. McLaughlin, Carnegie Institution Publications.

${ }^{86}$ Donelson to Calhoun, November 23, $18+4$ (received December 28); MS., Archives.

${ }^{87}$ Donelson to Calhoun, November 24, I844 (received December 28); MS., Archives.

${ }^{3 s}$ Yoakum, Texas, II., 443. 
The question was what the Congress of the United States would do.

In Mexico, Shannon, whose temperament seems to have been totally unfit for a diplomatic position, was engaged in a blustering correspondence with Rejon upon the subject of annexation. Santa Anna's downfall was plainly indicated. As the government weakened and a revolution became more and more imminent, Shannon's tone grew less and less conciliatory. Green, always a mischief maker, whose desires now went beyond the annexation of Texas and fastened themselves upon the acquisition of California, counselled Shannon upon the necessity of humbling Mexico. Green reported to Calhoun that Mexico would never consent to the annexation of Texas. "The present Government may therefore temporise, but we have nothing to hope from Mexico. They cannot reconquer Texas but they will not sell Texas." "39 "The Government of the United States have no alternative, that they cannot be content with the annexation of Texas. They must demand a withdrawal of the insolent charges and imputations contained in $\mathrm{Mr}$. Rejon's notes, and an immediate adjustment of all our, Claims against Mexico. This will not be done and a war must be the consequence." ${ }^{\text {to }}$ Shannon wrote that there was as much probability of the Emperor of China declaring war against the United States as that Mexico would do so. Without any authority from Calhoun, he notified the Mexican government that owing to the insolent tone of Rejon's communications,

${ }^{80}$ Duff Green to Calhoun, October 28, 1844; Report of $A m$. Hist. Association, 1899, II., 980.

${ }^{40}$ Green to Calhoun, November 12, I844; ibid., 993. 
he would suspend diplomatic intercourse with it until he had further instructions from home." Coinciding with Green's opinion that the United States "could not have peace with Mexico without a war," Shannon declared to Calhoun that nothing could be done with Mexico as to the settlement of any of the difficulties we have with her, "until we either whip her, or make her believe we will do so." "s

Having assisted Shannon in bringing relations with Mexico to an impasse, Green left to take up the duties of his consulate at Galveston. A quarrel with a fellowconsul soon occurred, and after an altercation with President Jones he was given his passports."

In Mexico the storm against Santa Anna, which had long been brewing, finally broke out into revolution.

"Shannon to Rejon, November 8, I844; MS., Archives. Niles' Register, LXVII., 26o-66.

${ }^{2}$ Green to Calhoun, November 12, 1844; Report, Am. Hist. Association, I899, II., 993.

"Shannon to Calhoun, November I2, I844; ibid., 995.

"The source of the Green quarrel was this: Green attempted to have the Texan congress pass a bill in aid of two companies, the Texas Land Company and the Del Norte Company. These companies had as objects the conquest and occupancy in behalf of Texas of the Californias and the northern provinces of Mexico by means of an army aided by Indians to be introduced from the United States upon the Texan frontier. Green offered stock in these companies to Jones if he would aid in the scheme. Upon Jones's refusal Green threatened to revolutionize the country and overthrow the existing government. Jones revoked Green's exequatur Dec. 3I, r844. Officers of the Government of Texas to Jones, December 30, 1844; Jones, Official Correspondence, 412. Elliott to Jones, January I4, I845; ibid., 4I3. Donelson to Calhoun, January 9, I845, enclosing Secretary of State Allen to Donelson, January I4, I845; MS., Archives. Donelson to Calhoun, January 25 (ibid.), stated that the trouble between Jones and Green had been settled. 
It culminated in the overthrow of Santa Anna on December 5, 1844. The council of state appointed, as president ad interim, General Herrera, a man of established probity of character, whose fault was timidity. His tendencies were for peace. Thus Mexico, by expelling the turbulent Santa Anna and replacing him with Herrera, took a long step toward the peaceful adjustment of relations with the United States upon the subject of Texas. A more competent diplomat than Shannon would have taken advantage of the change in Mexico's domestic affairs. Shannon, however, whose bad feeling dated from his arrival in the country, wanted Mexico chastised.

The course of events in Washington centered about the agitation for the passage through Congress of the resolution annexing Texas. Calhoun felt that while the House would favor annexation, the action of the Senate was problematical. ${ }^{45}$ Ingersoll's resolutions as amended by Brown of Tennessee passed the House on January 25, I845, by a vote of one hundred and twenty to ninety-eight. In the Senate Benton, reversing his earlier position, in which he demanded the previous consent of Mexico, now came forward with a proposition to annex Texas by what was practically the negotiation of a new treaty. The support of Benton and of those senators who followed him was necessary for the success of any annexation measure. A compromise, which gave to the President the power of selecting the alternative means, was offered and passed by a small majority. The joint

${ }^{45}$ Calhoun to R. M. T. Hunter, December 29, I844; Report, Am. Hist. Association, I899, II., 636. 
resolutions went to President Tyler March I, many believing that he would leave the final choice of measures to his successor, Polk.

Tyler's name, however, was to be inseparably associated with Texas. Calhoun had not been invited to continue with Polk. ${ }^{48}$ As soon as the resolutions reached the President, he and Calhoun determined to act at once. Selecting the method suggested by the House in preference to that which Benton claimed was the only constitutional mode, Tyler, on the day before he left the presidential office, despatched a special messenger to Texas to carry the joint resolution to Donelson, who was instructed to insist that the Texan government accede to the terms of the joint resolution. The reason for the deliberate choice of the House methods was stated to be that they were more simple in character and might more readily be carried into effect. "Nothing more is necessary than that the Congress of Texas be called together, its consent given to the provisions contained in it, and the adoption of a constitution by the people in convention, the same to be submitted to the Congress of the United States for its approval, in the same manner as when one of our own territories is admitted as a state. The decisive objection to the amendment of the Senate is that it would endanger the ultimate success of the measure." " It contemplated a new compact which must be ratified like any other treaty. Calhoun urged that the joint resolutions be adopted by the Texan congress without amendment and immediately. "The last hope on

"Calhoun to Mrs. Calhoun, March II, I845; ibid., 647.

${ }^{47}$ Calhoun to Donelson, March 3, 1845; S. Ex. Doc. I, 29 Cong., 2 Sess., 32. Tyler's Tylers, II., 364. 
the part of any foreign power, which may feel disposed to defeat annexation, will be to act upon the government of Texas, and it can scarcely be doubted from the feelings expressed on the part of one of the leading European powers against the measure, that no effort will be spared to induce Texas to reject the proposals contained in the Resolution." ts

It has been seen that Jones's policy as president of Texas was to follow two parallel lines of negotiation: the first, to hold the door open for annexation as long as there remained any reasonable ground for hope of getting it, the second, to lay the foundation for the separate independence of Texas as a nation in case annexation shouid ultimately fail. "Annexation or Unity, Independence and Peace with all the world." "9

Donelson learned of the passage of the Texas resolution while he was at New Orleans. He turned back to Texas with the important news only to find the French and English chargés closeted with Jones and the secretary of state, Ashbel Smith. Although ignorant of what project was under consideration, he felt sure that Jones was a friend of annexation. The result of the conference with Elliott and Saligny, the British and French representatives, was a memorandum of a treaty which included the conditions that Mexico acknowledge the independence of Texas, and that Texas promise that she would not annex herself, or become subject, to any country whatever. ${ }^{50}$ Elliott, without Donelson's knowledge, left Galveston

4 Ibid. See Donelson to Calhoun, April 24, 1845; Report Am. Hist. Association, I899, II., 1029.

"Jones; Official Correspondence, 473.

${ }^{50}$ Ibid., Memorandum of March 29, 1845 . 
for Mexico. In the mean time Jones temporized. At no time, however, did Donelson lose faith in the ultimate success of the measure, for Jones had assured him that he would submit the question to the people. As soon as Elliott had left for Mexico with the agreement for independence, Jones sent his secretary of state to Europe for the purpose of placing the relations of Texas with Great Britain and France upon a satisfactory footing should annexation fail. In case annexation triumphed Smith was to take leave of the two governments and close the legations. ${ }^{51} \quad$ The Mexican government accepted the proposals of Texas and the preliminary treaty was ratified by the Mexican congress. $^{52}$ Elliott returned with the treaty and Jones proclaimed peace with Mexico. It remained for the people of Texas to decide which path Texas should follow, that of independence or of union with the United States. A convention had already been called to consider the resolutions for annexation. The Texan congress indicated the feeling of the people in unanimously rejecting the Mexican treaty and voting for annexation. Upon the Fourth of July the convention of the Republic of Texas passed an ordinance with but one dissenting voice, agreeing to annexation with the United States. In October the people ratified the acts of the convention, and all that Texas could do toward annexation had been accomplished. The steps remaining for the admission of Texas as a state of the Union were to be taken by the Congress of the United States. In December Polk approved the joint resolu-

${ }^{61}$ Smith to Jones, April 9, 1845, and memorandum; Jones, Official Correspondence, 446.

${ }^{52}$ Ashbel Smith's Reminiscences, 72. 
tion of Congress admitting Texas as a state, and in February, I848, upon the surrender of authority by President Jones to Governor Henderson, Texas as a republic legally ceased to exist. ${ }^{33}$

Tyler gave way to Polk but not before he had signed the joint resolutions for annexation and determined which method of annexation should be followed. No two men could have been more different in character than Calhoun and Buchanan. As far as Texas was concerned, Polk did not reverse the decision of his predecessor. The incoming President proceeded to carry out the plans that Calhoun had decided upon. As soon as Tyler had signed the joint resolution, Almonte, the Mexican minister at Washington, departed, thus breaking off relations between his country and the United States. In giving notice to Buchanan of the termination of his mission Almonte denounced the action of Congress as "an act of aggression, the most unjust which can be found recorded in the counsels of modern history-namely, that of despoiling a friendly nation like Mexico of a considerable portion of her territory."

As Mexico had long since announced that annexation would be regarded by her as equivalent to a declaration of war, Almonte was forced to suspend relations to preserve his self-respect. He could do no less. Polk was justified in thinking that nothing would

${ }^{63}$ In the summer of 1845 Polk refused to receive a chargé from Texas. Had he then regarded Texas as a foreign state, he would have exceeded his powers in sending United States troops thither. Polk's Diary.

${ }^{84}$ Almonte to the Secretary of State, March 6, 1845; Brit. and For. State Papers, XXXIII., 246-48. 
come of Almonte's protest. As the administration of the peaceful Herrera was admittedly too weak to subjugate Texas, the prosecution of a war against the United States was at first hardly considered. Almonte's protest was received with expressions of regret that Mexico should have taken offense. "The President," Buchanan wrote Almonte, "although entering upon the duties [of his office], cheerfully declares in advance that his most strenuous efforts will be devoted to the amicable adjustment of every cause of complaint between the two governments and to the cultivation of the kindest and most friendly relations between the sister Republics." "s

With the departure of Almonte really ends the narrative of Texas annexation, as far as Mexico was concerned. It is commonly said that the Mexican War . was the result of the annexation of Texas, but the two were separate episodes which had no necessary connection. If Polk had had no ulterior designs upon Mexico, the Mexican War would not have taken place. Had the United States only the matter of Texas to settle with Mexico there would have been no difficulty. But Polk had greater ambitions than to act as Tyler's administrator de bonis non as to Texas: he coveted California from his entrance into office. Tyler's name is properly connected with Texas; with Polk belongs the glory, if glory it be, of the Mexican War and of the conquest of California.

${ }^{85}$ Buchanan to Almonte, March Io, $1845 ;$ ibid. 


\section{CHAPTER VIII}

The Northwestern Boundary Controversy I $803-1818$

It has been found necessary to review the history of the northeastern boundary question in order to present with sufficient clearness the problem that Ashburton and Webster essayed to solve. The northeastern boundary question was essentially one of geography, having its origin in the inaccuracies of the eighteenth century maps and in the ignorance of those who negotiated the peace treaty of 1783 . The northwestern boundary difficulty, solved in 1846 , was one of totally different nature. Interpretation of maps had nothing to do with it. It was a boundary question, which grew out of the westward expansion of the Anglo-Saxon people toward the Pacific. It was a controversy nearly as old as the northeastern question, but the succeeding phases of it had no resemblance to the controversy over the St. Croix, the Highlands, and the Connecticut River. That the two matters culminated in angry discussion at about the same time was, perhaps, only a coincidence. The two branches of the English-speaking races spread west beyond the Rockies and came in close contact, after a race across the continent, near the mouth of the Columbia.

The history of this expansion has in it much of the picturesque. Gray and Vancouver carried on the work of Drake, while the exploits of Lewis and Clark 
and of Mackenzie nobly followed out the hazardous undertakings of Champlain and of La Salle.

In the attempt to make good the territorial claims for which Gray and Lewis and Clark upon the one hand, and Vancouver and Mackenzie upon the other, furnished the opportunity, both the United States and Great Britain made use of every argument upon which color of title could be founded. Discovery, settlement, effective occupation, contiguity, and treaty rights were all made to do duty in some form. All of these lumped together failed to give either party a perfect right to the northwest coast of America. The result was a compromise no doubt just and equitable. The line of forty-nine degrees carried across the Rocky Mountains to the Pacific gave to Great Britain a stretch of coast that guaranteed to her for all time to come a position of effective commercial rivalry with the United States for the transcontinental and trans-Pacific trade of the world. Had the United States been able successfully to defend against Great Britain her claim up to fifty-four degrees, forty minutes (and a war would no doubt have resulted in the effort to enforce such a claim), the position of Great Britain, not only in reference to the North American continent, but also to the trade of the world, might have become secondary in importance. Great Britain was secured in her possession of a transcontinental trade-route long before such an idea was believed possible. The tortuous path of Mackenzie has been straightened into the line of the Canadian Pacific, whose port of departure to the Orient bears the name of Mackenzie's compatriot, the sailor Vancouver. 
By the treaty of peace of 1783 the western boundary of the United States was the Mississippi River south to the thirty-first degree of latitude. On the northwest the limits were from the northwesternmost point of the Lake of the Woods "thence on a due west course to the River Mississippi." Such a boundary was impossible, because a line due west from the northwesternmost point of the Lake of the Woods would have struck far to the north of the source of the Mississippi. It is to be noticed that this line of the treaty would have given Great Britain access to the Mississippi.

The rectification of the geographical error in the description of the boundary line, together with the $\checkmark$ question as to whether or not Great Britain had access to the Mississippi, is the genesis of the northwestern boundary question. The matter seems not to have had serious attention until the King-Hawkesbury negotiations of $1802 .{ }^{1}$ Calling attention to the error of the line of 1783 , Madison instructed King that this might be remedied by agreeing that the boundary should run from that source of the Mississippi nearest the Lake of the Woods, "striking it westwardly at a tangent and from the point touched along the watermark of the lake to its most northwestern point, at which it will meet the line running through the Lake."' Depending upon Mackenzie's report that the source of the Mississippi nearest the Lake of the Woods was about twenty-nine miles to the westward of the Lake, King agreed to a line drawn between

${ }^{1}$ Am. State Papers, For. Rel., II., 584-9r.

${ }^{2}$ Madison to King, June 8, I802; ibid., II., 585. Madison refers to Mackenzie's map, then recently published. 
these two points, and the convention, signed May I2, 1803, so declared the boundary. The Louisiana treaty, of which King then knew nothing,' upset the agreement that had been reached with Hawkesbury. The Senate struck out the fifth article relating to boundaries upon the recommendation of John Quincy Adams, then chairman of the committee to which the treaty was referred. The Senate feared that, as the King convention antedated the Louisiana treaty by twelve days, it might be held to operate as a limitation of the claims of the United States to Louisiana."

Monroe, who had been sent from Paris to London after the execution of the Louisiana treaty, was instructed by Madison to secure Great Britain's ratification of the King treaty with the fifth article omitted. Madison believed that there would be no difficulty in prevailing upon the British Government thus to accept the treaty, because, "first, it would be unreasonable that any advantage against the United States should be constructively authorized by the posteriority of the dates in question; the instructions given to enter into the convention and the understanding of the parties at the time of signing it, having no reference whatever to any territorial rights of the United States acquired by the previous convention with France, but referring merely to the territorial rights as understood at the date of the instructions for, and signature of, the British convention. . . . Secondly, if the fifth article be expunged, the north boundary of Louisiana will, as is reasonable, remain the same in the hands of the United States as it was in

' King to Madison, December 3, I803; ibid., II., 59I.

-Adams to Madison, December I6, I803; ibid., II., 590. 
the hands of France, and may be adjusted and established according to the principles and authorities which would in that case have been applicable. Thirdly, there is reason to believe that the boundary between Louisiana and the British territories north of it was actually fixed by commissioners appointed under the treaty of Utrecht, and that this boundary was to run from the Lake of the Woods westwardly in latitude forty-nine degrees; in which case the fifth article would be nugatory, as the line from the Lake of the Woods to the nearest source of the Mississippi would run through territory which on both sides of the line would belong to the United States. . . . Fourthly, laying aside, however, all the objections to the fifth article, the proper extension of a dividing line in that quarter will be equally open for friendly negotiations after, as, . . . considering the remoteness of the time at which such a line will become actually necessary, the postponement of it is of little or no consequence." These instructions are of importance because in them is the first suggestion of the line of forty-nine degraes as a boundary between the United States and the British possessions to the west of the Lake of the Woods. Madison said that "there was reason to believe" that commissioners under the treaty of Utrecht had decided upon that parallel as the division between French and British territories. In support of this assertion, Madison enclosed a paper setting forth the reasons for believing that the Utrecht commissioners had decided upon the line of forty-nine degrees. What these arguments were cannot be known except indirectly, as the paper referred to is not extant. Madi-

${ }^{5}$ Madison to Monroe, February I4, I804; ibid., III., 89. 
son, however, confessed to Monroe that recourse must be had to the "proceedings of the commissioners, as the source of authentic information." At about the same time Madison urged Livingston at Paris to make a thorough search in support of the line of forty-nine degrees. ${ }^{.}$Madison then admitted that he had no official information upon which to rest the claim for the proposed boundary. While commissioners were appointed under the treaty of Utrecht after I7I9, there is no evidence that they ever marked out a line. ${ }^{7}$ The line of forty-nine degrees, which divides British North America from the United States across more than half the continent, rests upon a mistaken idea. Salmon, in his Modern Universal History, published in 1738 , stated that the Utrecht commissioners had chosen as the dividing line between the Hudson Bay territories and Canada one drawn from the coast of Labrador in latitude fifty-eight degrees, thirty minutes, "southwest of Lake Mistissin and thence farther southwest to the latitude of forty-nine degrees." The Topographical Description of Louisiana, by Hutchins, published in 1784 , copied this assertion "verbatim without addition or remark." 8

'Madison to Livingston, January 3I, I804; ibid., II., 574.

${ }^{7}$ At least beyond the Lake of the Woods. Cf. Bancroft to Fish, September I, 1873; MS., Archives. Quoted by J. C. B. Davis, Notes, etc., I324, n. Cf. Von Holst, History, III., 33 .

${ }^{8}$ Greenhow, Oregon, edition of 1847 , p. 436. Apparently the first denial that the line of forty-nine degrees was determined by the Utrecht commissioners was made by Greenhow in the Washington Globe of January 15, 1840: "Summary of facts respecting the Northwest coast of America." See his memoir of the Northwest Coast of America, 216. Upon the British side, Twiss, The Oregon Question Examined, 208I4, agrees with Greenhow's contention. 
It will be noticed that Salmon brought the line down to the forty-ninth parallel. Douglas's Summary of the British Settlements in North America, published in 1749 at Boston, stated that the line went not only to the forty-ninth parallel, but also extended indefinitely westward in that latitude. Bolton's map of America inserted in Postlethwayt's Dictionary of Commerce marked the line of forty-nine degrees, and in a note a statement is made that this line had been settled "by commissaries, after the peace of Utrecht, making a course from Davis's Inlet, on the Atlantic Sea, down to the forty-ninth degree, through the Lake Abitibis, to the North-west ocean." Thus in unofficial maps, dating from the middle of the eighteenth century, the forty-ninth parallel was represented as the dividing line between British and French possessions through to the Pacific Ocean. There was no basis in fact for such an idea. Mitchell's map, as used by the negotiators of 1782 , which had been the source of so much confusion over the northeastern boundary, showed no such dividing line upon the northwest. Upon it there is no reference to the forty-ninth parallel. This imaginary line, therefore, was immediately after the purchase of Louisiana put forth by the United States as the ancient northern boundary of the newly acquired possession. It was an American and not a British suggestion.

Monroe found that it was not so easy to persuade

- See excellent maps in Channing's Jeffersonian System, pp. 6 and 70 . The substitution of a parallel of latitude for a natural watershed as the boundary of Louisiana accounts in some measure for the erroneous idea, subsequently maintained, that Louisiana extended indefinitely west. 
Great Britain to accept the King-Hawkesbury convention without the fifth article. Addington had given way to Pitt, and Lord Harrowby, who took Hawkesbury's place, strongly reprobated the practice of ratifying treaties in part "as one unauthorized and unsanctioned by public law and usage." Monroe attempted, in accordance with Madison's instructions, to explain the Senate's action. Harrowby observed with some degree of severity that the United States was not disposed to ratify the fifth article when it was found that by it territory was ceded with which the United States did not wish to part. Monroe resented "the injustice of the insinuation" and offered to leave the ratification, but Harrowby refused to receive it. "The conduct of Lord Harrowby," Monroe reported to Madison, "through the whole of this conference was calculated to wound and to irritate," and he felt that the consideration of the matter was indefinitely postponed. $^{10}$ At a subsequent interview Monroe stated that it was not contemplated by either Great Britain or the United States that the latter should convey to the former any right to the territory lying westward of the line between the Lake of the Woods and the Mississippi, "since not a foot of it belonged to her; it was intended to leave it to Great Britain to settle the point as to such territory, or such portion of it as she might want, with Spain, or rather with France, to whom it then belonged." The stipulation of the fifth article had become by the Louisiana treaty nugatory, for, "as Great Britain holds no territory south of the

${ }^{10}$ Monroe to Madison, June 3 , I804; Am. State Papers, For. Rel., III., 93. 
forty-ninth parallel and the United States the whole of it, the line proposed by that article would run through a country which now belongs exclusively to the United States." "11 Thus the United States took the position that the parallel of forty-nine degrees was the dividing line between Louisiana and the British possessions, whereas the true boundary of Louisiana upon the north was the watershed enclosing the territory drained by the Mississippi-Missouri rivers. Soon after this second interview with Lord Harrowby, Monroe went to Spain upon his special mission, returning to England in July, $1805 .^{12}$ Upon his return he waited for some months for Harrowby to resume the consideration of the northwestern boundary. Monroe was disappointed at the delay. In January, I806, Pitt died and Grenville and Fox formed a new ministry. Monroe hoped that Fox would inaugurate a change in the policy of Great Britain toward the United States. ${ }^{13}$ For months Monroe was unable to draw Fox's attention to the question of boundary. Jefferson, holding that Jay's treaty had expired, then sent William Pinkney to act jointly with Monroe in the negotiation of a new treaty. ${ }^{14}$ This joint commission was not instructed to discuss the boundary question, but Monroe was separately authorized to "bring that business to a conclusion. If any repugnance should be shown to the erasure of the fifth article as proposed by the Senate, and thereby leaving unsettled

${ }^{11}$ Monroe to Madison, September 8, 1804; ibid., III., 95. Monroe to Lord Harrowby, September 5, I804; ibid., III., 97.

${ }^{12}$ Monroe to C. J. Fox, February 25, I806; ibid., III., II4.

${ }^{13}$ Monroe to Madison, January 28, I806; ibid., III., III.

${ }^{14}$ Jefferson's Writings, Ford's Ed., XIV., 178, n. 
for the present the boundaries in the northwest quarter of the Union, and preference should be given to a proviso against any constructive effect of the Louisiana convention on the intention of the parties at the signature of the depending convention, you may concur in the alteration with a view to bring the subject in that form before the ratifying authority of the United States." 15

The treaty which Monroe and Pinkney signed with Vassal Holland and Auckland was not submitted to the Senate by Jefferson, as it contained no abandonment of Great Britain's claim to impress American citizens. ${ }^{18}$ Pinkney and Monroe continued their negotiations until Grenville's ministry retired and Canning became secretary for foreign affairs. Monroe and Pinkney reported that Canning's professions were, on the whole, conciliatory. ${ }^{17}$ Negotiations were soon renewed for a convention upon the boundary. The American commissioners proposed that "the division line between our respective territories [upon the northwest] ought to be drawn from the most northwestern point of the Lake of the Woods due north or south until it shall intersect the parallel of forty-nine degrees, and from the point of such intersection due west along and with that parallel." This was agreed to by the British commissioners, who, however, followed by proposing that "this line of forty-nine degrees should ex-

${ }^{15}$ Madison to Monroe, May 15, 1806; Am. State Papers, For. Rel., III., IIg.

${ }^{18}$ Madison to Monroe and Pinkney, February 3, I807; ibid., III., 153.

${ }^{17}$ Monroe and Pinkney to Madison, April 22, I807; ibid., III., I6o. They had not then heard of Jefferson's attitude toward their treaty. 
tend west as far as the territories of the United States extend in that quarter." 18 The purpose of the British suggestion was evident to Monroe and Pinkney. Both sides agreed that nothing in the article "should be construed to extend to the northwest coast of America, or to the territories belonging to or claimed by either party on the continent of America to the westward of the Stony Mountains." "10 To limit the line of fortynine degrees so that it would go only as far as the territories of the United States might extend in that quarter would, so Monroe and Pinkney believed, leave it open for Great Britain afterwards to found a claim to any part of the country west of the beginning of that line. The American commissioners feared that such a claim might be made on the ground of occupation or even by purchase from Spain, and their feelings were shared by Madison, who wanted no such provise. "It would have little other effect," he wrote, "than as an offensive intimation to Spain that our claims extend to the Pacific Ocean. However reasonable such claims may be compared with those others, it is impolitic, especially at the present moment, to strengthen Spanish jealousies of the United States, which it is probably an object with Great Britain to excite by the clause in question." 20 Before Madison's warning reached Monroe and Pinkney the question of a boundary was overshadowed by a more serious affair, that of the Leopard and Chesapeake. ${ }^{21}$ The matter of the

${ }^{18}$ Monroe and Pinkney to Madison, April 25, I807; ibid., III., 162.

${ }^{10} \mathrm{Ibid}$., III., 165 .

${ }^{20}$ Madison to Monroe and Pinkney, July 30, I807; ibid., III., I85.

${ }^{21}$ Canning to Monroe, July 25, I807; ibid., III., I87. 
northwestern boundary was not discussed again until after the War of I8I2. The negotiation of Monroe and Pinkney, though fruitless, had some lasting effect. Great Britain and the United States were agreed that the line of forty-nine degrees was suitable, at least as far as the Rocky Mountains. Neither Madison, Monroe, nor Pinkney was certain as to the extent of Louisiana to the west, but none of them contended that the United States had any rights to the west of the Rocky Mountains as against Spain. Then, too, Madison was unwilling to discuss the question of boundary indefinitely westward along the line of fortynine degrees for fear of offending Spain. Furthermore, as the whole question of right to the western country was at that time deemed of little importance, Madison was perfectly willing to leave the matter in abeyance.

At the first conference of the American and British peace commissioners at Ghent, held August 8, I8I4, the latter proposed the revision of the boundary line without specifying what part of it should be altered. They disclaimed any intention of desiring to acquire additional territory, and represented the proposed revision as intended merely for the purpose of preventing uncertainty and dispute. ${ }^{22}$ At a later conference ${ }^{23}$ a more specific proposal was made. The British commissioners proposed that the boundary line west of Lake Superior and thence to the Mississippi be revised and the treaty right of Great Britain to the navigation of the Mississippi be continued. Surprised at

${ }^{22}$ American Commissioners to Monroe, August I2, I8I4; ibid., III., 705 .

${ }^{23}$ August 19, I8I4. 
such a proposition, the American members asked if the Lake of the Woods were not meant instead of Lake Superior. "The British commissioners repeated that they meant the line from Lake Superior to that river." ${ }^{24}$ The American answer to this was that whatever the object of Great Britain might be in thus proposing to take over a tract of territory larger than the whole island of Great Britain, the duty of the American commissioners was plain: "they have no authority to cede any part of the United States, and to no stipulation to that effect will they subscribe." ${ }^{25}$ To this it was replied that as the necessity for fixing some boundary for the northwestern frontier had been mutually acknowledged, a proposal for a discussion of that subject could not be considered as a demand for a cession of territory, "unless the United States were prepared to assert that there is no limit to their territories in that direction." ${ }^{28}$ The British commissioners then proposed the line from the Lake of the Woods to the Mississippi (as set forth in the KingHawkesbury convention of 1803 ), but they admitted that they were willing to discuss any other boundary. In the refusal of Adams and his colleagues to permit a boundary line between the territory of the United States and the Indian nations, the British sought to show that the Americans were actuated only by mo-

${ }^{24}$ Adams, et al., to Monroe, August I9, I8I4; Am. State Papers, For. Rel., III., 709.

${ }^{25}$ American to British Commissioners, August 24, I8I4; ibid., III., 7I2.

${ }^{26}$ British to American Commissioners, September 4, I8I4; ibid., III., 7I4. 
tives of aggrandizement "afforded by the purchase of Louisiana from France." ${ }^{27}$

To dwell upon the successive steps of the long and difficult negotiation which resulted in the adoption of the status quo ante bellum, with the exception of the islands in Passamaquoddy Bay, is manifestly impossible in the limits of this chapter. As the boundary lines were uncertain, it was a logical step to arrange for the appointment of commissioners to trace the disputed boundary line according to the terms of the treaty of 1783 . In the consideration of the restitution by Great Britain of all the places taken by her of which the United States had possession prior to hostilities, Monroe reminded the Americans at Ghent that "the United States had in their possession at the commencement of the war, a post at the mouth of the River Columbia, which commanded the river, which ought to be comprised in the stipulation, should the possession have been wrested from us during the war. On no pretext can the British Government set up a claim to territory south of the northern boundary of the United States. It is not believed that they have any claim whatever to territory on the Pacific ocean. You will, however, be careful, should a definition of boundary be attempted, not to countenance in any manner, or in any quarter, a pretension in the British Government to territory south of that line." ${ }^{2 s}$ Monroe thus proceeded upon the same theory according to which Madison had instructed him in I804. Madi-

${ }^{27}$ British to American Commissioners, September 19, I814; ibid., III., 7I8.

${ }^{28}$ Monroe to American Commissioners, March 22, I8i4; ibid., III., 73I. 
son's assumption was that by the Louisiana treaty the United States acquired an indefinite westward stretch of territory bounded on the north by the line of fortynine degrees. For the first time the line was suggested as extending as far west as the Pacific Coast. As has been seen, there was no foundation for such an assumption. The settlement at the mouth of the Columbia was not made because of the Louisiana cession. The foundations of a claim for the mouth of the Columbia were (I) the sea-ward discovery of that river by Gray in I792; (2) the results of the Lewis and Clark expedition, and (3) the settlements made by Astor's fur-traders shortly before the War of 1812 . The rights growing out of these various elements appear in the later phases of the discussion. At present it is noteworthy that Monroe did not base the right of the United States to the restoration of Astoria, the settlement at the mouth of the Columbia, upon any of them. It was boldly asserted that Great Britain, if it' had any claim on the Pacific, certainly had none south of forty-nine degrees.

The question as to the sovereignty and possession of the mouth of the Columbia was only incidentally touched upon during the Ghent negotiation. Although the principle of status quo ante bellum had been admitted, the British commissioners proposed to limit the restoration of the territory taken by either party during the war to those places that, belonging to one party, had been taken by the other. To this modification of the principle the Americans strenuously objected. Restoration, according to them, should be predicated upon the fact of possession prior to the war and not upon the mere right. The adoption of 
the British point of view would have entailed endless disputes upon every possession in question. During the discussion Bayard stated that the proposed alteration would give rise to a new dispute, even with the utmost fidelity and sincerity on both sides. "One party claims the delivery of territory taken from it, and which it sincerely and honestly believes to belong to it. The other refuses to deliver it, believing with equal sincerity and confidence that it belongs to itself. Suppose the case that the place belongs to neither of the parties. Suppose the case that it belongs to both. On either of these suppositions you have immediately a new dispute. The restoration of the state existing before the war is a plain and simple principle, a matter of fact, about which no dispute can arise." ${ }^{29}$ This exposition by Bayard, to which no reply was made, had, as he told Adams, particular reference to the settlement of Astoria, concerning which the American commissioners had been specifically instructed.

The American commissioners made a proposal similar to the one agreed to by Monroe, Pinkney, Auckland and Holland in $1807:{ }^{30}$ that the line drawn due north and south from the Lake of the Woods to the line of forty-nine degrees, thence west along that parallel, should be "the dividing line between His Majesty's territories and those of the United States, as far as the said respective territories extend in that quarter." The British counter-project was that the line should extend only as far as the territories of the United States might extend. Both agreed that the

${ }^{20}$ J. Q. Adams, Memoirs, III., 8I. Cf. Greenhow's Oregon, ed. of 1847,306 .

${ }^{30} \mathrm{~J}$. Q. Adams, Memoirs, III., 84. 
article should not be construed to refer to any territories to the west of the Rocky Mountains or upon the Pacific Ocean. ${ }^{31}$ The British also asked for access to the Mississippi. Upon this last proposition and the attempt to hedge in the claims of the United States to the west the mission disagreed. ${ }^{32}$ Finally the Americans offered to omit altogether the article relative to the northwestern boundary, ${ }^{33}$ and the treaty of peace was signed with the line of boundary from the Lake of the Woods to the west undetermined.

The treaty provided for commissioners to run the line to the Lake of the Woods and to fix the most northwest point of that lake, but further than this nothing was stipulated. The line of forty-nine degrees as far west as the Rocky Mountains was acceptable to both parties, and although the article was nearly agreed upon, the discussion went off upon a collateral incident ${ }^{34}$ and the treaty left the question open.

After the ratification of the treaty of Ghent, the question of Astoria presented itself as one distinct from the general question of the northwestern boundary. With the history of the settlement of the mouth of the Columbia and the American attempt to dispute the British monopoly of the fur-trade in the northwest

${ }^{31}$ Article 8 of projet and counter-projet; Am. State Papers, For. Rel., III., 738.

${ }^{32}$ J. Q. Adams, Memoirs, III., 72, 84.

${ }^{33}$ Ibid., III., 85. Gallatin stated that while it would be a convenience to have the boundary settled, yet the lands were of so little value and the period when they might be settled was so remote that the United States was perfectly willing that the boundary should remain without any further arrangement.

${ }^{34}$ Adams to Gallatin, May 22, I8I8; Am. State Papers, For. Rel., IV., 371. J. Q. Adams, Memoirs, III., 94, 120. 
it is impossible here to concern ourselves. It has been shown that Monroe instructed Adams and his fellownegotiators to see that Astoria should be restored to the United States because Great Britain was believed to have no claims upon the west coast of America, at least south of the line of forty-nine degrees. Monroe's assertion was remarkable for what was omitted: that Astoria had been an effective occupation, the proper sequence of the American discovery of the mouth of the Columbia by Gray in I792. This argument was not brought forward until, in later negotiations, the question of the sovereignty over the northwest coast had become inseparably connected with the general question of the northwestern boundary.

The settlement at Astoria under the auspices of the Pacific Fur Company was begun in I8II. Within a few months thereafter the agents of the British Northwest Company reached the American settlement overland by way of the northern branch of the Columbia. With varying fortunes the factory at Astoria was maintained by the Pacific Fur Company until after the outbreak of the war with Great Britain. In the fall of 1813 , in anticipation of capture by a British squadron (information having reached Astoria that a naval force was on its way to take and destroy everything American on the northwest coast), the agents of the Pacific Fur Company sold all of their establishments, furs, and stock on hand to the British Northwest Company. ${ }^{35}$ Some ten weeks after the transfer had been made the British sloop of war Raccoon ap-

${ }^{35}$ October I6, I8I3. Greenhow, 442, gives the text of the agreement between the agents of the two companies. 
peared at the mouth of the Columbia. To the disgust of the commander, who had visions of battering down the American fortifications and perhaps of securing some booty, the place had already been put into the possession of the British company. The establishment of the Pacific Fur Company, which had been dreaded as a rival, no longer existed. Astoria was renamed Fort George, and the Raccoon left the Columbia. Thus was the settlement of Astoria one of those places directly affected by that clause in the treaty of peace which required the restoration of all places possessed by either party before the outbreak of the war. It is manifest that the restoration of Astoria under the treaty, according to the view for which Bayard had so earnestly contended, was wholly inconclusive as to rights of sovereignty over the mouth of the Columbia. The question of possession before the war was one of fact, and this the United States was not slow to raise.

The treaty of peace was proclaimed February I8, I $815^{36}$ During the negotiations at Ghent, Bentzor, a son-in-law of Astor, reported to Gallatin that steps would be taken, as soon as he learned of the terms of the peace agreement, to renew the settlement at the Columbia before the British could anticipate the movement. ${ }^{37} \quad$ As all the commissioners were under a promise of secrecy, it is possible that Bentzon did not know what the treaty contained until it had been signed. ${ }^{s s}$ Astor's activities were directed in urging Madison's administration to effect the restoration of Astoria

${ }^{36}$ Treaties and Conventions, 399.

${ }^{37} \mathrm{~J}$. Q. Adams, Memoirs, III., 90.

${ }^{38}$ Ibid., III., I27. 
under the provisions of the treaty. In July, I8I5, Monroe drew the attention of Baker, the British chargé, to the fact that an expedition that had been sent by the British government "against a post of the United States, established on Columbia River, had succeeded in taking possession of it." Baker was then informed that, as the United States would be entitled to the possession of this post under the treaty, measures would be taken to reoccupy it without delay. "It is probable that your government may have given orders for its restitution; to prevent, however, any difficulty on the subject, I have to request that you will have the goodness to furnish me with a letter to the British commander there to that effect." ${ }^{30}$ Baker in reply pleaded lack of instructions upon the subject. ${ }^{40}$ No further action was taken during Madison's term of office. In September, 1817, the sloop of war Ontario was despatched to the mouth of the Columbia in accordance with the notice peremptorily given Baker. Captain Biddle, commanding the vessel, and J. B. Prevost were jointly commissioned to restore the American flag over Astoria and to "assert the claim of the United States to the sovereignty of the adjacent country in a friendly and peaceable manner and without the employment of force." No attempt was made to conceal the purpose of this mission, although no communication was made to Bagot, the British minister, concerning it." Bagot, after a personal inquiry from

${ }^{39}$ Monroe to Baker, July I8, I815; Am. State Papers, For. Rel., IV., 852.

${ }^{40}$ Baker to Monroe, July 23, I823; ibid.

"Adams said the omission was accidental. Adams to Rush, May 20, I8I8; ibid., IV., 853. 
Adams, formally asked for an explanation of the action of the United States in reference to the settlement upon the Columbia. $\mathrm{He}$ insisted that while Astoria had been captured during the war, the Americans had previously retired from it under an agreement with the Northwest Company, "who had purchased their effects, and who had ever since retained peaceable possession of the coast." ${ }^{42}$ In his interviews with Adams, Bagot suggested that Great Britain had claims upon the northwest coast that would conflict with the American occupation of the Columbia. He then definitely asked what the intentions of the United States were toward the northwest coast. Adams declined answering the inquiry or discussing the claims otherwise than in writing. The correspondence ended with a request for an explanation as to the purpose of the Ontario voyage. Castlereagh sought to obtain from Rush, who had just arrived as minister to the Court of St. James, the explanation that Bagot had failed to have from Adams. The British foreign secretary coupled for the first time the matter of the possession of the Columbia with the general question of the northwestern boundary. The second step of the negotiation was thus reached. Before this, all discussion turned upon the question of the boundary between the British possessions and the United States to the west of the Lake of the Woods. Possession of the mouth of the Columbia was an isolated question, at first completely separated from the general one of boundary. From now on until the Oregon compromise was effected the northwestern boundary

${ }^{12}$ Bagot to Adams, November 26, I817; ibid., 852 . 
question was merged into that of Oregon; Oregon became the general term to designate the valley of the Columbia.

Castlereagh, considering jointly the two subjects of the northwestern boundary and of the post at the Columbia River, proposed to Rush that the question of title to the territory upon the northwest coast, together with the northeastern and northwestern boundary disputes, should be referred to commissioners for settlement, with a provision for arbitration in case the commissioners could not agree. ${ }^{43}$ Rush naturally pleaded lack of instructions. As far as the line west of the Lake of the Woods was concerned, he doubted if any arrangement could be had, as the original boundary did not touch the Mississippi, and any modification of it to the south would bring the line through territory admittedly within the limits of the United States. The Astoria matter Rush declined to discuss further than to declare that the right of the United States to restitution could not be impeached under the stipulations of the Ghent treaty. "I mentioned the cases of Nootka Sound and Falkland Islands. In these, Great Britain, under circumstances far less strong, had asserted the principle of which we claimed the benefit.'

The Nootka Sound treaty, which was afterwards to play an important part in the Oregon question, was introduced by the United States as an argument for the restitution of Astoria. In October, I790, the representatives of Great Britain and Spain signed the

${ }^{43}$ Rush's Residence, ed. of $1833,73-76$.

"Ibid., 74. Rush to Adams, February I4, I818; Am. State Papers, For. Rel., IV., 853. 
convention of the Escurial, commonly called the Nootka Sound treaty. To attempt in this place an account of the controversy ended by the convention of the Escurial would be collateral to the general subject. ${ }^{45}$ In 1789 the Spanish seized two English vessels at Nootka Sound and carried a part of their officers and crews as prisoners to Mexico. Plans for an English establishment at Nootka were thus forcibly, interrupted. The action of the Spanish officials, viewed as an isolated event, would, perhaps, have had important results, but taken in connection with the strained relations then existing between Great Britain and Spain, and the general political condition of Europe, the occurrence at far-off Nootka brought the two countries to the verge of war.

The first purpose of the Escurial convention was, as Rush suggested, to effect the restitution of the British establishments at Nootka. Spain agreed to restore to the British subjects "the buildings and tracts of land situated on the Northwest Coast of North America, or on islands adjacent to that continent of which the subjects of his Britannic Majesty were dispossessed in April, I789." "s Mutual restitution was agreed upon for any similar acts of either party toward the other subsequent to the occurrence at Nootka. So far the treaty is easily capable of interpretation. In later articles more general terms were employed, and upon the scope of these all claims founded upon the Nootka treaty really rested. It was

${ }^{45}$ For a comprehensive account, see Manning's "The Nootka Sound Controversy" in Report of the Am. Hist. Association, 1904, pp. 279-478.

${ }^{46}$ Article 2 of Treaty of October 28, I790. Manning, 454. 
agreed that the respective subjects of Spain and Great Britain should not be disturbed or molested either in navigating or in carrying on their fisheries in the Pacific Ocean or in the South Seas, or in landing on the coasts of those seas in places not already occupied, for the purpose of carrying on their commerce with the natives of the country or of making establishments there. ${ }^{47}$ This general provision, which was manifestly a concession from Spain to Great Britain, was specifically restricted by the stipulation that British subjects should not carry on navigation or fishing within ten leagues of "any part of the coast already occupied by Spain." The concession was not to be made a cloak for illicit trade with the Spanish colonies in America, either in North or South America. The fifth article of the treaty refers to the northwest coast only: "It is agreed that as well in the places which are to be restored to British subjects by virtue of the first article as in all other parts of the Northwest Coast of North America or of the isles adjacent, situated to the north of the parts of the said coast already occupied by Spain, wherever the subjects of either of the two powers shall have made settlements since the month of April, I789, or shall hereafter make any, the subjects of the other shall have free access and shall carry on their commerce without disturbance or molestation." 48

What did Great Britain gain by this convention? Did she acquire from Spain sovereign rights or any title to any part of the Pacific Coast? Or did Great

"7 "Pour y former des établissements." French text in Martens, Recueil, IV., 495.

${ }^{48}$ Ibid., 455. Cf. Von Holst, III., 42. 
Britain succeed in limiting the commercial system of Spain to those parts of America that were Spanish colonies in fact as well as in name? In other words, was the Nootka Sound convention an agreement respecting territorial title or colonial commerce? "It was the first express renunciation of Spain's ancient claim to exclusive sovereignty over the American shores of the Pacific Ocean and the South Seas. It marks the beginning of the collapse of the Spanish colonial system." "It was an admission that the Spanish system of monopolizing colonial trade was to be limited to those countries that were in fact colonies; that in a large part of the territories over which Spain claimed sovereignty it was impossible to extend the Spanish colonial system and to inhibit trade that was in theory illicit. It is impossible to read into the Nootka treaty the broad doctrine that for the northwest coast of America there must be an effective occupation in order to give good title. ${ }^{50}$ No amount of effective possession by Great Britain south of the actual Spanish settlements of I790 could have produced under the treaty a good title as against Spain. Viewing the treaty as a whole (and of course in no other way can it be interpreted), the conclusion is irresistible that by it the theory of the Spanish colonial system was modified to meet actual conditions upon the Pacific coast of America. Spain agreed, provided Great Britain did not attempt any exclusive methods in the same territories, not to consider as illicit the trade along those coasts to which she had long

${ }^{40}$ Manning, 462.

${ }^{60}$ Such a principle as $e$. g., the Berlin act of 1885 , adopted for the conventional basin of the Congo. 
claimed title, but over which her colonial administration had not actually extended.

The treaty was criticised in Spain for having "conceded to England what had always been resisted and refused to all powers since the discovery of the Indies." "O1 "Our right, before the convention," said Fox in opposition, "whether admitted or denied by Spain was of no consequence,-was to settle in any part of South or Northwest America, not fortified against us by previous occupancy; and we were now restricted to settle in certain places only, and under certain conditions. Our rights of fishing extended to the whole ocean; and now it was limited, and not to be exercised within certain distances of the Spanish settlements. Our right of making settlements was not, as now, a right to build huts, but to plant colonies, if we thought proper."

The sequel to the Nootka treaty is very significant. In January, I794, a convention was signed at Madrid which provided for the abandonment of Nootka not only by Spain, but by Great Britain as well. Acknowledging that by the treaty of 1790 the subjects of both powers had equal rights of frequenting the port of Nootka, it was now agreed that "neither of the said parties shall form any permanent establishment in the said port or claim any right of sovereignty or territorial dominion there to the exclusion of the other. And their respective Majesties will mutually aid each other to maintain for their subjects free access to the

${ }^{51}$ Iriarte to Floridablanca, October 27, I790; quoted by Manning, 457.

${ }^{62}$ Quoted by Greenhow, Oregon, 213; and by Von Holst, III., 42. 
port of Nootka against any other nation which may attempt to establish there any sovereignty or dominion."

Except as an argument for the restitution of Astoria under the treaty of Ghent as raised by Rush, the Nootka Sound question was not regarded as germane to the subject of the respective territorial claims of Great Britain and the United States in I8I8. Upon Rush's report of his conversation with Castlereagh, Adams wrote, May 20, 1818, that "as it was not anticipated that any disposition existed in the British Government to start questions of title with us on the borders of the South Sea," the United States had nothing to conceal about the purposes of the voyage of the Ontario. Adams instructed Rush to suggest to Castlereagh, "though not unless in a manner to avoid everything offensive in the suggestion, that, from the nature of things, if in the course of future events it should ever become an object of serious importance to the United States, it can scarcely be supposed that Great Britain would find it useful or advisable to resist their claim to possession by systematic opposition. If the United States leave her in undisturbed enjoyment of all her holds upon Europe, Asia, and Africa, with all her actual possessions in this hemisphere, we may very fairly expect that she will not think it consistent either with a wise or friendly policy to watch with eyes of jealousy and alarm every possibility of

${ }^{83}$ I. e., Russia. Cf. Monroe to Madison, September 8, I804; Am. State Papers, For. Rel., III., 95. Text of the Madrid convention in Manning, 469. It was first published by Calvo in I862, and hence probably nothing was known of it by American diplomats during the Oregon controversy. 
extension to our natural dominion in North America, which she can have no solid interest to prevent, until all possibility of her preventing it shall have vanished." ${ }^{44}$

This was bold language. There was something of an absurdity in the idea that the United States would leave undisturbed the British possessions in Europe, Asia and Africa. As to her rights in America, a more practical view was taken: the United States desired Great Britain not only to keep within her acknowledged limits, but to interpose no objection to the territorial expansion of the United States as a matter in which she had no concern or interest. It is doubtful if Rush found an opportunity to communicate Adams's surprising suggestion to Castlereagh "without avoiding everything offensive," for Rush, soon after the receipt of Adams's letter, had an interview with Castlereagh in which he went over the whole range of unsettled matters between the United States and Great Britain. The conversation was amicable, and Rush offered to reopen the negotiation of the northwestern boundary, joining with it the question of the title to the Columbia. ${ }^{55}$ If Great Britain would consider these two subjects, together with that of the slaves carried off in contravention of the treaty of Ghent and that of the fisheries, in aldition to the general question of commerce, the United States would appoint a plenipotentiary to act with Rush. Castlereagh promptly accepted Rush's invitation, and Gallatin, the minister to

${ }^{54}$ Adams to Rush, May 20, 1818; Am. State Papers, For. Rel., IV., 854.

${ }^{55}$ Rush's Residence, 269-74. Rush to Adams, July 25, I818; Am. State Papers, For. Rel., IV., 374, 854. 
France, who had been appointed special minister at the Court of St. James some months before, ${ }^{56}$ arrived at London in August, ${ }^{57}$ and the negotiation was immediately begun. ${ }^{68}$ During the negotiation Castlereagh left England to attend the Congress at Aix-la-Chapelle. The British case was entrusted to Robinson, president of the Board of Trade, and Goulburn, an under-secretary of state. The details of the negotiation as to commerce, fisheries and slaves are outside the scope of the present inquiry. Adams had proposed under separate heads the discussion of the northwestern boundary and the title to the Columbia. Rush noticed that the two subjects could not be kept apart. ${ }^{50}$ The subject of the northwest boundary line, which as Adams wrote Gallatin was all but agreed upon at Ghent but "went off upon a collateral incident," ${ }^{80}$ was opened just as it had been in the earlier negotiations in 1806 and 1814 . Adams instructed the American plenipotentiaries that the earlier British proposals could not be agreed to; this was to take the line of forty-nine degrees westward from the Lake of the Woods as far as the territories of the United States extended in that direction, with a caveat against its extension beyond the Rocky Mountains. Adams made two objections to this: (I) that it was not certain that any part of the Lake of the Woods was in latitude forty-nine, and (2) that Great Britain "always affected

${ }^{56}$ Adams to Gallatin, May 22, I818; Am. State Papers, For. Rel., IV., 37I.

${ }^{57}$ August 16. Rush's Residence, 306.

${ }^{63}$ August 23, at Lord Castlereagh's country seat; ibid.

${ }^{50}$ Ibid., 339.

${ }^{60}$ Adams to Gallatin, May 22, I818; Am. State Papers, For. Rel., IV., 372. 
to apply the indefinite limit of extension 'as far as the territories extend' to the territories of the United States, and not to those of Great Britain, leaving a nest-egg for future pretensions on their part south of latitude forty-nine." os Gallatin and Rush were instructed to hold to the line of forty-nine degrees as far as the territories of both parties extended, with a proviso against extension beyond the Rockies. Such an instruction separated the northwestern boundary from the consideration of the title to the Columbia. Upon these questions Adams declined an arbitration, especially one by Russia, which had "pretensions" upon the northwest coast. "The delineation of an unsettled boundary across the western deserts of this continent, the title to establishments upon the Pacific ocean, . . where, save pretensions, there is no object to any party worth contending for,- - to create burdensome commissions and make solemn references to a foreign sovereign for these, appears scarcely to be necessary, if altogether justifiable." ө2

Throughout the course of the negotiation Robinson and Goulburn refused to discuss the boundary line unless some arrangement were made as to the territories west of the Rocky Mountains. Rush and Gallatin thereupon proposed that the line of forty-nine be extended to the Pacific. "We did not assert that the United States had a perfect right to the country, but that their claim was at least good as against Great Britain." Believing that the line of forty-nine had been fixed under the treaty of Utrecht, there was no reason why it should not be extended to the Pacific.

"Adams to Gallatin and Rush, July 28, 1818; ibid., IV., 377.

${ }^{2}$ Ibid., IV., 378. 
So far as discovery gave any claim, Rush and Gallatin maintained that Gray's finding of the mouth of the Columbia, followed by the discoveries of Lewis and Clark, gave a claim to the United States that was indisputable. Robinson and Goulburn answered that the discoveries of Cook forestalled any rights claimed under Gray's voyage, and that no boundary would be agreed to which did not at least leave the mouth of the Columbia in common with the United States. To this the American representatives said that rather than concede any such right they would prefer to leave open the whole question of possession and sovereignty west of the Rocky Mountains.

Immediate settlement was urged by Robinson and Goulburn, and they proposed a boundary westward of the Rockies as follows: "In order to prevent any disputes as to the territorial rights of either of the contracting parties on the northwest coast of America, or anywhere to the westward of the Stony mountains, it is agreed that so much of the said country as lies between the forty-fifth and forty-ninth parallels of latitude, together with its harbors, bays, and creeks, and the navigation of all rivers within the same, shall be free and open to the subjects and citizens of the two states, respectively, for the purpose of trade and commerce; it being well understood that, although by virtue of this arrangement, the two high contracting parties agree not to exercise as against each other any sovereign or territorial authority within the above mentioned country lying between the forty-fifth and forty-ninth parallels of latitude, this agreement is not to be construed to the prejudice of any claim to which either of the two high contracting parties may have 
to any territorial authority in any part of the country lying within the said limits; nor shall it be taken to affect the claim of any other Power or State to any part of the said country; the only object of the two high contracting parties being to prevent disputes and differences between themselves." ${ }^{\text {s }}$

In this British proposition is the principle of joint occupancy and possession. There was in it no recognition of the sovereignty of either Great Britain or the United States over the territory. No attempt was made to prejudge the claims of Spain. Manifestly it was a proposal to which the United States could not agree. Nothing whatever was said about the territory north of the line of forty-nine, to which as yet the United States had laid no claim. The British representatives sought to gain joint possession of all the territory westward of the Rocky Mountains over which the United States asserted sovereignty. Gallatin and Rush rejected the proposed article, declaring that they would sign no boundary agreement to territory either west or east of the Rocky Mountains rather than acquiesce in such an arrangement. "We did not know with precision what value our Government set on the country to the westward of those mountains, but we were not authorized to enter into any agreement which would be tantamount to an abandonment of the claim to it." "

The American representatives, however, did not drop the boundary question. They would not throw into a common stock that part only of the country to which

${ }^{\text {es }}$ Article B, annexed to Protocol of 5th Conference, October 6, I8I8; ibid., IV., 39I.

${ }^{64}$ Rush and Gallatin to Adams, October 20, 1818; ibid., IV., $38 \mathrm{I}$. 
the United States denied the claim of Great Britain, which lay south of forty-nine degrees. They were not authorized to agree to any expressions implying a renunciation of territorial sovereignty, although they did not insist on an extension of the line of forty-nine west of the mountains. ${ }^{65}$ The line of the forty-ninth degree as far as the Rockies was acceptable to both parties. Provided no limits were placed upon the territory to the west of the mountains, Gallatin and Rush were willing to accept the principle of joint occupation for a limited term of years as a modus vivendi, and to this, though with a show of reluctance, Goulburn and Robinson agreed."

Thus the idea of joint occupation proposed by Great Britain, in terms unlimited as to time but limited to the territory south of forty-nine degrees, was modified by the representatives of the United States by a limita . tion of time to ten years and the removal of all territorial limitations. The British position was intended, of course, to secure the fur-trade of the West. Joint occupation would interfere in no way with the only sort of commerce that the western country then afforded. The idea that the vast territories beyond the Rockies and along the Pacific Coast were susceptible of settlement had not yet arisen. The acceptance by the United States of the programme of joint occupation had in no sense the character of permanence. As yet the idea of territorial expansion in its proper sense found no place in the discussion of the Oregon question. Joint occupation was agreed to as a practicable

${ }^{e s}$ Protocol 5, ibid., IV., 392.

${ }^{68}$ Protocol 6, October 9, I818; ibid., IV., 393. Gallatin and Rush to Adams, October 20, I818; ibid., IV., 38r. 
modus vivendi under which territorial claims might be conserved until conditions were ready and public sentiment was ripe for a solid and definite assertion of those claims. It was believed that the question had no immediate importance. Though basing territorial claims upon discovery and settlement, the United States admitted that it had no perfect right to the valley of the Columbia and the northwest coast. Upon the receipt of the convention for joint occupation, Monroe accepted the work of Gallatin and Rush, and the Senate ratified it with but little debate. ${ }^{67}$ By it the restoration of Astoria was confirmed, the British surrendered all claim to access to the Mississippi, the northwestern boundary was settled as far as the Rocky Mountains, and the territory to the west was left under joint occupation for ten years; the only object of the whole being "to prevent disputes and differences amongst themselves." That the object failed to serve its purpose will be seen in the next chapter upon the development of the Oregon dispute during the period of joint occupation.

${ }^{87}$ Convention signed October 20, 1818, sent to Senate December 29, 1818, and ratified January 30, 1819; Treaties and Conventions of U.S. and Foreign Powers, 4I5. 


\section{CHAPTER IX}

The Joint Occupation of Oregon I8I8-I 846

The period of joint occupation (I8I8-1846) cannot be described within the limits of the present volume with all the detail that the proper treatment of the subject merits. The events of these three decades can be discussed but briefly and then only as they bear upon the question of the development of the problem that so many American diplomatists tried to solve. Adams, Clay, Rush, Gallatin, and Calhoun, each of these devoted much attention to it. The attempted settlement of $1823-24$ resulted only in a restatement of the conflicting claims of Great Britain and the United States. When the first joint-occupation agreement expired by limitation in 1828 , the parties to it were so far apart that no solution was possible. Joint occupation was continued indefinitely. In the nego- tiations of $1823-24$ and of 1827-28 many new elements entered into the discussion, complicating the general problem.

Rush's negotiation of $1823-24$ was really a collateral incident in the more general matter of the Monroe Doctrine. The discussion began upon the publication of the Czar's ukase of September 4-16, I821, by which Russian subjects were granted exclusive rights along the western coast of North America north of the fifty-first degree of latitude. In the discussion that followed Adams's protest against the Czar's pretensions, Poletica, the Russian minister at Washington, 
stated that the line claimed as the southern limit of Russia's pretension was half way between the northernmost settlement of the United States, that at the mouth of the Columbia in latitude forty-six degrees, and the Russian post of New Archangel in latitude fifty-seven degrees.' Adams forebore entering into an argument with Poletica further than to state that Russia's claim to the fifty-first degree, as a line equidistant from the Columbia and New Archangel, was greater than that made in I799, when the line of fifty-five degrees was defined as the southern limit of the grant to the Russian-American Company.

The ratifications of the Florida treaty of I8I9 were exchanged February 22, I821. By it Spain ceded all of her American territory north of forty-two degrees. Before the treaty was signed Adams had stated to Rush that he did not anticipate that Great Britain would start questions of title with the United States on the borders of the Pacific." The claim of the United States west of the Rocky Mountains and north of forty-two degrees was then based upon discovery, on the Pacific side by Gray and his successors, and overland by Lewis and Clark, and upon the indefinite extent of the Louisiana Purchase, as well as upon the establishments made along the coast by American traders. As the successor of Spain upon the Pacific Coast north of forty-two degrees, the United States

${ }^{1}$ Poletica to Adams, February 28, 1822; Am. State Papers, For. Rel., IV., 861-63. See Hildt, Early Diplomatic Negotiations of the United States with Russia. JoHns Hopkins Univ. Studies, XXIV., i6o, $s q q$.

${ }^{2}$ Adams to Poletica, March 30, 1822; Am. State Papers, For. Rel., IV., 863.

${ }^{3}$ Adams to Rush, May 20, I818; ibid., IV., 853. 
began the negotiations by which Adams hoped a delimitation of the territorial claims of Russia and Great Britain might be effected. The questions raised by Poletica Adams sent to Middleton at St. Petersburg for further discussion. The instructions to Midaleton, dated July 22, I823, and those to Rush at London bearing the same date, are of the utmost importance, not only on account of the statement of the claims of the United States as against Russia and Great Britain, but because they contain the formal statement as to the territorial pretensions of European powers in North America that reappears in Monroe's famous message of December 2, 1823 .

This is no place for a discussion of that muchdiscussed and much-abused term, "The Monroe Doctrine," the meaning of which varies with each successive clash between the United States and any European power concerning American affairs. Writing to Middreton, Adams said that the United States had acquired all the rights of Spain north of forty-two degrees; that by the treaty of 1818 with Great Britain any country claimed by either party was open to the citizens and subjects of the two powers without prejudice to the claims of either party or of any other state. As Russia had claims upon the Pacific Coast, Adams authorized Middleton to propose an article of the same import for a term of ten years from the signature of a joint convention between the United States, Great Britain, and Russia. "The right of the United States from the forty-second to the forty-ninth parallel of latitude on the Pacific Ocean we consider

${ }^{4}$ Ibid., V., 436-48; J. Q. Adams, Memoirs, VI., I63. 
as unquestionable," and the firmest basis of that right Adams stated to be the cession from Spain under the Florida treaty. "This territory is to the United States of an importance which no possession in North America can be of to any European nation, not only as it is but the continuity of their possessions from the Atlantic to the Pacific Ocean, but as it offers their inliabitants the means of establishing hereafter communications from the one to the other." Adams believed that Russia could have but one reason for desiring possessions in America, and that was for the purpose of irading with the natives. "By offering free and equal access for a term of years to navigation and intercourse with the natives to Russia, within the limits to which our claims are indisputable, we concede much more than we obtain." Adams's observations as to Russia's claim were given in an enclosure to the letter just quoted. In the course of it Adams made use of the following memorable words: "There can, perhaps, be no better time for saying, frankly and explicitly, to the Russian Government, that the future peace of the world, and the interest of Russia herself, cannot be promoted by Russian settlements upon any part of the American Continent. With the exception of the British establishments north of the United States, the remainder of both the American continents must henceforth be left to the management of American hands. It cannot possibly be the purpose of Russia to form extensive colonial establishments in America. The new American Republics will be as impatient of a Russian neighbor as the United States; and the

${ }^{5} i$. e., east of the Rocky Mountains. 
claim of Russia to territorial possession, extending to the fifty-first degree of north latitude, is equally incompatible with the British pretensions." Therefore, "the United States can in nowise admit the right of Russia to exclusive territorial possession on any part of the continent of North America south of the sixtieth degree of north latitude."

The instructions to Rush, bearing the same date, repeated the arguments given to Middleton. "It is not imaginable that, in the present condition of the world, any European nation should entertain the project of settling a colony on the Northwest Coast of America. That the United States should form establishments there, with views of absolute territorial right and inland communication, is not only to be expected, but is pointed out by the finger of nature, and has been for many years a subject of serious deliberation in Congress." As Great Britain had also protested against the ukase of I82I, Adams believed that the proper time had arrived for Great Britain and the United States to come to a "mutual understanding with respect to their respective pretensions, as well as upon their joint views with those of Russia."

With these instructions of Adams to Middleton and Rush were begun the prolonged negotiations as to Oregon that Polk finally settled upon a compromise basis. They are the starting point of the various lines of argument that succeeding secretaries of state made use of. In Adams's position were elements both of strength and weakness. He proposed a tripartite agreement by which Russia, Great Britain, and the United States were to be secured each in its own possessions. $\mathrm{He}$ 
emphasized the rights that the United States had acquired from Spain. He brought forward the Nootka Sound convention in support of the claims of the United States under the Florida treaty, as a fair and subsisting agreement. His introduction of the doctrine that the American continent was no longer to be the field for European colonial enterprise became the rock upon which was shattered any hope of agreement with Great Britain, either alone or in a tripartite agreement with Russia. The Nootka Sound convention was susceptible of two interpretations: either it was an agreement between Great Britain and Spain, which had expired at the outbreak of the war in 1796 and was not afterwards renewed, or it embodied such general principles relating to commerce, navigation, and territorial possessions on the Pacific as not only to give it permanency, but to bind the United States as the successor of Spain. If the latter were the correct interpretation, Great Britain would be in a position to combat the claims of the United States to the exclusive ownership of any territory west of the Rockies and north of forty-two degrees. By Adams's interjection of the Nootka Sound convention into the question of the northwest coast in support of the American claim, the United States was estopped from asserting that it was an agreement concerning a condition of affairs no longer existing."

- $C f$. Greenhow, History of Oregon and California, 340: "The introduction. . . . of the Nootka convention. . . . appears to have been wholly unnecessary, and was certainly impolitic. No allusion had been made to that arrangement in any of the previous discussions with regard to the north- 
Adams held that the "principles" settled by the Nootka Sound convention were: (I) that the rights of fishing and of trade with the natives on the northwest coast and "of making settlements on the coast itself for the purposes of that trade, north of the actual settlements of Spain, were common to all the European nations, and of course to the United States, and (2) that Spain's exclusive territorial rights, as they existed in I790, extended ten miles from the coasts so actually occupied . . . The exclusive rights of Spain to any part of the American continent have ceased. That portion of the convention, therefore, which recognizes the exclusive colonial rights of Spain on these continents, . . has been extinguished by the fact of

west coasts, and it was doubtless considered extinct; but when it was thus brought forward by the American government in connection with the declaration against European colonization, as a settlement of general principles with regard to those coasts, an argument was afforded in favor of the subsistence of the convention, of which the British government did not fail to take advantage." Cf., also, Twiss, The Oregon Question Examined, 289. "In the course of the conference, the American plenipotentiary stated that he was instructed to insist on the principle that no part of the American continent was henceforward to be open to colonization from Europe. To explain the principle, he stated that the independence of the late Spanish provinces precluded any new settlement within the limits of their respective jurisdictions; that the United States claimed the exclusive sovereignty of all the territory within the parallels of latitude which include as well the mouth of the Columbia as the heads of that river, and of all its tributary streams [i.e., to fifty-one degrees]; and that with respect to the whole of the remainder of that continent not actually occupied, the powers of Europe were debarred from making new settlements by the claim of the United States as derived under their title from Spain.

"The British plenipotentiaries asserted, in utter denial of the above principle, that they considered the unoccupied parts 
the independence of the South American nation [sic] and of Mexico. Those independent nations will possess the rights incident to that condition, and their territories will, of course, be subject to no exclusive right of navigation in their vicinity, or of access to them by any foreign nation." From these statements Adams drew the principle of non-colonization: "A necessary consequence of this state of things will be, that the American continents, henceforth, will no longer be subjects of colonization. Occupied by civilized independent nations, they will be accessible to Europeans and to each other on that footing alone, and the Pacific Ocean in every part of it will remain open to the navigation of all nations, in like manner with the Atlantic." Without entering on a discussion as to

of America just as much open as hitherto to colonization by Great Britain, as well as by other European powers, agreeably to the convention of 1790 between the British and Spanish Governments, and that the United States would have no right whatever to take umbrage at the establishment of new colonies from Europe in any such parts of the American continent." Protocol of June 29, 1824;Am. State Papers, For. Rel., V., 563 .

Thus the United States derived the principle of noncolonization from the territorial rights of Spain, to one part of which the Spanish-American states had succeeded by their wars of independence, and to the other the United States under the Florida treaty. Great Britain opposed it upon the ground that by the Nootka Sound convention Spain had waived her exclusive territorial sovereignty in favor of the doctrine of actual settlements. It was unfortunate that Adams and Rush made use of the phrases "actual settlements" and "actually occupied," which appear in the Nootka Sound convention. "The principle upon which England insists is, that the Northwest coast of America, north of the actual establishments of Spain, ought not to be deemed to belong exclusively to any European." Confidential Memorial, ibid., V., 450. 
the correctness of Adams's construction of the Nootka Sound convention, it is manifest that the introduction of the so-called non-colonization principle into the instructions to Middleton and Rush was largely by a statement of fact, being a description of the condition of affairs in America as they existed June 22, I823. Adams made a statement of fact which he doubtless believed would assist in settling the claims of the three powers to the Pacific Coast north of latitude fortytwo degrees. That the American continents were no longer subject to European colonization was an assertion that the American continents contained no unoccupied land. The former colonies of Spain in South America had been recognized as independent nations. What had been the Portuguese colony of Brazil was no longer subject to Portugal, although governed by the House of Braganza. France, Holland, and Great Britain, it is true, supported colonies upon the South American continent, but each colony was hedged about by the territory of an independent state. In North America the conditions south of the line of forty-two degrees were precisely similar. The Central American states were independent, as well as Mexico, and surrounded the British colony of Belize, the only European colony on the continent between the United States and the Isthmus of Panama. Adams admitted that both Russia and Great Britain had territorial rights upon the northwest coast: "You are authorized . . with a view to draw a definite line of demarkation for the future, to stipulate that no settlement shall hereafter be made on the Northwest Coast or on any of the islands thereto adjoining by Russian subjects south of latitude fifty-five degrees, by citizens 
of the United States north of latitude fifty-one degrees, or by British subjects either south of fifty-one degrees or north of fifty-five degrees. I mention the latitude of fifty-one degrees, as the bound within which we are willing to limit the future settlement of the United States. . . As, however, the line already runs in latitude forty-nine degrees to the Stony mountains, should it be earnestly insisted upon by Great Britain, we will consent to carry it in continuance on the same parallel to the sea."

That Adams should have sought to arrange a line with Great Britain to the exclusion of Russia or with Russia to the exclusion of Great Britain occasions no surprise or criticism. When Rush made known to Canning the tenor of his instructions, the proposition that the United States should limit Great Britain on the north to fifty-five degrees," Canning declined to join with the United States in negotiating with Russia. Rush was given to understand that Great Britain would proceed separately. Canning's willingness to enter into a joint negotiation with Russia and the United States had been based upon the idea that Russia's extravagant maritime pretensions in the Pacific would be the only subject for settlement. Into the discussion of the relative territorial pretensions of Russia and the United States he refused to enter.'

"The resumption of its original course by this Gov-

'Adams to Rush, July 22, 1822; Am. State Papers, For. Rel., V., 446-48.

${ }^{8}$ Rush to Middleton, December 22, I823; ibid., V., 463.

' Hildt, Early Diplomatic Negotiations of the United States with Russia, I70. 
ernment [Great Britain] has arisen chiefly from the principle which our government has adopted, of not considering the American continents as subject to future colonization by any of the European powers, a principle to which Great Britain does not accede." 10

The negotiation upon which Rush was instructed was thus discredited before it was begun. He was forced to report in August, I824, that after eight months the negotiation had been brought to a close without any treaty or other arrangement on any of the subjects entrusted to him. ${ }^{11}$ The prolonged discussions, however, gave opportunity for both the British and American claims to be set forth fully for the first time. Rush assumed responsibility for proceeding after Canning had refused to enter into a joint negotiation with Russia and the United States. He proposed an extension for a further term of ten years of the jointoccupation agreement of 1818 , coupling it with a proviso that Great Britain during that time should make no settlements between the fifty-first and fifty-fifth degrees, and the United States should make none north of latitude fifty-one. The British plenipotentiaries, Huskisson and Stratford Canning, promptly declined Rush's proposition. They offered as a counter-proposition that the joint-occupation agreement be terminated and that the boundary line of forty-nine degrees be extended west beyond the Rocky Mountains "to the point where it strikes the northeasternmost branch of the Columbia, and thence down the middle of the Columbia to the Pacific Ocean."

${ }^{10}$ Rush to Middleton, January 9, I824: Am. State Papers, For. Rel., V., 463 .

${ }^{11}$ Rush to Adams, August 12, 1824; ibid., V., 533-82. 
Rush immediately declared his inability to accept the proposed boundary, but in accordance with Adams's permission offered the line of forty-nine degrees to the Pacific. Huskisson and Canning held Rush's final offer under consideration for a fortnight, and then rejected it, making no new proposal in return. They told Rush that what they had offered was as much as Great Britain would concede.

In the mean time Middleton at St. Petersburg was endeavoring to reach an understanding with Nesselrode. He felt himself handicapped by the defection of Great Britain, whose minister was engaged in an independent negotiation. Middleton believed that Great Britain had abandoned all thoughts of keeping open the trade upon the northwest coast. "Her object in this negotiation seems to be to obtain an abandonment of the extravagant maritime pretensions set up by Russia, and at the same time to acquire for herself territorial rights." ${ }^{12}$ Although Adams had said that the United States could not admit the right of Russia to exclusive territorial possessions in America south of sixty degrees, he was willing, in case Great Britain and Russia joined in a treaty settling their respective territorial claims, to recognize Russia's claim as far south as fifty-five degrees. Middleton proceeded to treat with Russia according to the terms of the instructions that were framed for the tripartite agreement.

Middleton's first projet was that "no settlement shall be made hereafter on the northwest coast of America, or on any of the islands adjacent thereto, north of the

${ }^{12}$ Middleton to Adams, April 19, 1824; ibid., V., 46r. 
fifty-fifth degree of north latitude, by citizens of the United States. . . . nor by the Russian subjects . . . south of the same parallel of latitude."13 The line of fifty-five degrees was approximately the southern limit of the grant of I799. Middleton was convinced that Russia's claim to so much of the northwest coast was valid, as the ukase of I799, although a domestic act and never communicated to the other powers, had remained unquestioned for more than twenty-five years. The Emperor he found willing enough to rescind the ukase of $182 \mathrm{I}$, but not the earlier one, as "the act of his father must be maintained." ${ }^{14}$

"The fifty-fifth degree was therefore a barrier not to be broken through; and a further small addition was required because the point of an island [Prince of Wales Island] was cut off by that parallel. In consequence of this, it was urgently pressed by the Russian plenipotentiaries to make the line of delimitation run upon a parallel of fifty-four degrees, forty minutes, a small deviation from the instructions $I$ had received. To this I thought I could, without impropriety, accede." $1 \mathrm{~s}$

The convention as signed April 17, I824, preserved Middleton's phraseology: that the citizens of the United States should not form any establishment on the northwest coast of America north of fifty-four de-

\footnotetext{
${ }^{13}$ Projet of the United States of February 8, I824; ibid., V., 464 .

${ }^{14}$ Middleton to Adams, April 19, I824; ibid., V., 46r.

${ }^{15}$ Ibid., V., 46I. "The proposal of inserting fifty-four degrees, forty minutes, instead of fifty-five degrees, was with a view to preserving to Russia two points of the island in which the port, called Bucarelli by the Spaniards, is situate;" ibid., V., 459 .
} 
grees, forty minutes, and that Russian subjects should form none south of that line. The convention further stipulated that for a period of ten years the citizens or subjects of either power should have free access "upon the coast mentioned" for the purpose of fishing and trading with the natives. ${ }^{16}$ There was no ambiguity in the terms of this convention, but Russia proceeded upon the theory that while her rights were secure north of fifty-four degrees, forty minutes, the United States had no rights south of that line which she was bound to respect. ${ }^{17}$ In February, 1825, Great Britain and Russia concluded a treaty by which it was stipulated that "the line of demarkation between the possessions of the high contracting parties upon the coast of the continent, and the islands of America to the northwest" should begin at the southernmost point of Prince of Wales Island, in latitude fifty-four degrees, forty minutes, thence eastward to the Portland Channel, thence to the fifty-sixth degree, "which line shall form the limit between the Russian and British possessions in the continent of America to the northward." ${ }^{18}$

The negotiation begun by Adams for the settlement of the northwestern boundary dispute was a failure. His assertion of the "non-colonization" principle put the British government in no proper mood for friendly negotiation. Adams's plan for a tripartite settlement of the questions of boundary was one which, if Great Britain had any territorial rights whatever upon the

10 Treaties and Conventions between the United States and Foreign Powers, 931. The treaty was proclaimed January 12, 1825 .

${ }^{17}$ Greenhow, op. cit., 342 .

${ }^{18}$ Text of treaty in Greenhow, 479-81. 
Pacific coast, she could hardly agree to. Canning told Rush that he could see a motive for the United States' desiring to stop the settlements of Great Britain southward, but that the boundary between the British and Russian possessions was not a matter in which the United States could be interested. Canning's position was sound. Adams had stated in $18 \mathrm{I} 8$ that he did not anticipate that Great Britain would start questions of title with the United States on the Pacific. Four years later he asserted that Russia could have no motive for establishing colonies in America. Yet he offered to limit the claims of the United States if Russia and Great Britain would jointly agree to limit theirs. The convention that Middleton signed furnished a phrase that afterwards came perilously near becoming a war-cry, but it gave to the United States no rights that she could use against Great Britain. Middleton's convention merely stipulated that American citizens should not settle north of fifty-four degrees, forty minutes, or Russian subjects south of it. The Russo-British treaty made a definite boundary line between the possessions of the two countries, and each power recognized the right of the other in and to the northwest coast north and south of fifty-four degrees, forty minutes.

All the lines of argument which in later negotiations were elaborated by Rush and Gallatin, and by Calhoun, were taken up by Adams in the first negotiation after the Florida treaty had made the United States the successor of Spain north of forty-two degrees. Discovery, settlement, contiguity, and purchase from Spain, Adams argued, together gave to the United States complete title to the northwest coast. But how far 
to the north? As against Russia he first claimed to the sixtieth parallel, then to the fifty-fifth; as against Great Britain to the fifty-first and finally to the fortyninth. At the close of Adams's negotiation the position of the United States was the same as when Polk took up the problem in 1845 . The United States, though claiming that her rights extended much farther to the north, was willing as a compromise to accept the line of forty-nine degrees westward from the Rocky Mountains to the Pacific. Great Britain insisted upon the line of forty-nine degrees only as far west as the Columbia. It was upon the Columbia River that the powers split. The exclusive right to the Columbia was one that neither would concede to the other.

As the ten years' period of joint occupation under the convention of $18 \mathrm{I} 8$ was about to expire, Canning suggested in April, I826, that the negotiations for the settlement of the northwestern boundary be resumed. ${ }^{10}$ Adams and Clay selected Gallatin to reopen the question at London. Clay's instructions to Gallatin followed closely those that Adams had given to Rush three years before. ${ }^{20}$ The extension of the line of forty-nine degrees to the Pacific coast Gallatin was told to announce as an ultimatum. Later Clay authorized him to concede to Great Britain the free navigation of the Columbia. ${ }^{21}$

Gallatin's negotiation, which lasted until August, I827, resulted in the renewal of the agreement for joint occupation for an indefinite period, terminable by either

${ }^{10}$ Canning to King, April 20, 1826; Am. State Papers, For. Rel., VI., 645 .

${ }^{20}$ Clay to Gallatin, June I9, I826; ibid., VI., 644.

${ }^{21}$ Clay to Gallatin, August 9, 1826; ibid., VI., 646. 
party upon twelve months' notice. The text of the convention is brief, reciting that the third article of the convention of 1818 was renewed. The provision of the earlier instrument was continued to the effect that joint occupation should not be construed to impair or to affect the claims of either power to the territory west of the Rockies. The convention of 1818 reserved the rights of any third power as well as of Great Britain and the United States. As the United States had succeeded to the rights of Spain, and Russia had been limited to the territory north of fifty-four degrees, forty minutes, this clause was not renewed.

It is impossible to enter into detail as to the negotiation of the convention of 1827 . The arguments presented by both sides were similar to those of Rush, Huskisson, and Stratford Canning at an earlier date. The temper of the British had not changed, and Gallatin was all the time conscious of the influence that Monroe's non-colonization principle had in arousing the jealous suspicions of the British ministry. ${ }^{22}$ The British commissioners rested their case upon the Nootka Sound convention, and insisted that all of the territory west of the Rocky Mountains and north of forty-two degrees was vacant. Gallatin's argument ably presented the claim of the United States to fifty-four degrees, forty minutes, and combated the validity of the Nootka Sound convention upon the ground that it was abrogated by the war of 1796 . In the course of the proceedings Gallatin's views changed. He soon became convinced that there could be no agreement upon

${ }^{22}$ Gallatin to Clay, December 20, I826; ibid., VI., 659. 
the line of forty-nine degrees, but he was opposed to a renewal of the joint-occupation article, fearing that Great Britain would consolidate actual possession of the whole, or nearly the whole, of the territory in dispute. $^{23}$ Later he came to favor the renewal of that article after the reiterated declaration by the British commissioners that Great Britain had no exclusive claim upon the disputed territory. Gallatin was convinced that after all "what the United States might want was the very object which Great Britain declared to be hers, viz., the preservation of peace until the whole country was occupied."

The approval by George Canning of Gallatin's plan for a renewal of the joint-occupation agreement was about the last act of that statesman. In forwarding the new agreement to Clay, Gallatin remarked: "National pride prevents any abrupt relinquishment of her pretensions; but Great Britain does not seem indisposed to let the country gradually and silently slide into the hands of the United States; and she is anxious that it should not in any case become the cause of a rupture between the powers. . . . My opinion is that the country must necessarily be settled by the United States, and ultimately fall into their hands, provided the natural course of events is not prevented, and merely by suffering them to take their course."

The debates in Congress, the various plans of fortifying the territory held by joint occupation, the schemes for its territorial organization and for the settlement of the country by emigrants from the United States,

${ }^{23}$ Gallatin to Clay, October 30, I826; ibid., VI., 647.

${ }^{24}$ Gallatin to Clay, June 27, 1827 ; ibid., VI., 680.

${ }^{25}$ Gallatin to Clay, August 10, I827; ibid., VI., 694. 
are outside the scope of the present inquiry. The steady stream of settlers along the Oregon Trail that began in the late thirties showed that Gallatin's judgment was correct. The danger was that by aggressive measures on the part of Congress for the occupation of Oregon the "natural course of events might be prevented." . 


\section{CHAP'TER X \\ ThE OREGON TREATY \\ I846}

Although Aberdeen had given Ashburton specific and detailed instructions for the settlement of the northwestern boundary question as well as of the other matters in dispute between Great Britain and the United States, little if anything was done toward it. The northeastern question was considered the more pressing, and Webster feared that if he and Ashburton attempted to settle both boundary difficulties the whole of the negotiation would fall through. ${ }^{\prime}$ As soon as the ratifications of the Ashburton treaty were exchanged, Aberdeen urged that the remaining cause of friction between the two countries be removed. Fox communicated Aberdeen's overture to Webster, who stated that the President favored giving the Oregon question immediate attention. ${ }^{2}$ In his message to Congress at the beginning of the session in December, 1842 , Tyler said that he would not delay to urge upon Great Britain the importance of an early settlement of this longstanding controversy. ${ }^{3}$ As it was Aberdeen and not Tyler who had opened the door for negotiation, the

${ }^{1}$ Aberdeen to Fox; October I8, I842; Correspondence relative . . . to the Oregon Territory, Parliamentary Papers, I846, folio, I.

${ }^{2}$ Webster to Fox, November 25, 1842 ; ibid., 2.

3 Tyler's message of December 6, I842; Richardson's Messages, IV., 196. 
statement of Tyler was not altogether frank. Aberdeen complained to Fox of Tyler's failure to state "that he had already received from the British government a pressing overture to negotiate an adjustment." “ When the President was called upon by the Senate for information as to the state of the negotiation and the reasons why it had not been included in the Ashburton treaty, Tyler replied that as the matter was then pending it was inexpedient to make any communication upon the subject. ${ }^{3}$ At the time this message was made no step had been taken by Webster in accordance with Aberdeen's suggestion. Tyler contemplated sending Webster on a special mission to London, and only reluctantly abandoned the idea. Webster left Tyler's cabinet without entering upon the discussion of the Oregon question. After Upshur's appointment Aberdeen again urged that the business be taken up, either through Everett at London, or through Fox at Washington." Upshur informed Fox that the President was anxious to have the matter settled, and preferred that the negotiation proceed at Washington. ${ }^{2}$ In the face of this do-nothing attitude, Tyler stated in his annual message of 1843 that "our minister at London has under instructions again brought the subject to the attention of that government; and while nothing will be done to compromit the rights or honor of the United States, every proper expedient will be

-Aberdeen to Fox, January I8, I843; Correspondence relative . . . to the Oregon Territory, 3 .

'Tyler's message of December 23, I842; Richardson's Messages, IV., 210.

-Aberdeen to Fox, August 18, 1843; Correspondence rilative . . . to the Oregon Territory, 5.

${ }^{7}$ Fox to Aberdeen, September 12, I843; ibid., 5. 
resorted to in order to bring the negotiation, now in the progress of resumption, to a speedy and happy termination." " "After the most rigid and, as far as practicable, unbiased examination of the subject, the United States have always contended that their rights appertain to the entire region of country lying on the Pacific and embraced within forty-two degrees and fifty-four degrees, forty minutes of north latitude." This statement, although not conciliatory, was not offensively bold, nor did Aberdeen so consider it.' Tyler again recommended the establishment of military posts along the overland routes to Oregon for the security and protection of emigrants against the Indians. "Our laws should also follow [the emigrants], so modified as the circumstances of the case seem to require. Under the influence of our free system of government, new republics are destined to spring up at no distant day on the shores of the Pacific similar in policy and in feeling to those existing on this side of the Rocky Mountains, and giving a wider and more extensive spread to the principles of civil and religious liberty.'

Late in I843 Pakenham replaced Fox, and Aberdeen entrusted the Oregon negotiation to him, as he preferred to have it conducted at Washington while Con-

${ }^{8}$ Tyler's message of December 5, I843; Richardson's Messages, IV., 258. Cf. Tyler's Tylers, II., 439. While Everett was instructed by Upshur, October 9, I843, to propose the line of forty-nine degrees and "any other terms of compromise which in the progress of his discussions might appear to promise a satisfactory adjustment of this important question," the tender was to be made informally. Aberdeen wrote Pakenham, December 28, I843, that nothing had been accomplished since December, 1842 .

- Aberdeen to Pakenham, December 5, I843; Correspondence relative. . . to the Oregon Territory, 7 . 
gress was in session. Before Pakenham and Upshur began the consideration of the question the disaster upon the Princeton occurred. Not until late in August, I844, did Upshur's successor, Calhoun, announce that he was ready to resume the negotiation, which had remained as Gallatin left it in I827.

Calhoun's position upon the Oregon question had been fully set forth in his speech in the Senate of January $24,1843 \cdot{ }^{10}$ He favored a policy of "wise and masterly inactivity." In but one way, he stated, could the Oregon territory be preserved to the United States. "Time is acting for us; and if we shall have the wisdom to trust its operation, it will assert and maintain our right with resistless force, without costing a cent of money or a drop of blood." He opposed any proposition for the occupation of Oregon upon the ground that it would invite a contest by Great Britain resulting in the loss of the whole country. Gallatin's idea, that the preservation of the status quo of joint occupation was the surest method not only of keeping peace but of ultimately holding the disputed region, was adopted by Calhoun. After the failure of the Texas treaty he was disinclined to open the Oregon question. It is stated that he was "peremptorily" ordered to take up the subject where Upshur had left it, and try for a settlement by the line of forty-nine degrees. ${ }^{11}$ Tyler was anxious that the long-pending question should be ended during his administration. Calhoun, whose views as to the advisability of delay had not changed, began the discussion with Pakenham. His method was one that promised an immediate settlement upon

${ }^{10}$ Calhoun's Works, IV., 238.

${ }^{11}$ Tyler's Tylers, II., 44I. 
the basis of compromise. The plan that Webster and Ashburton had adopted, of considering the matter without protocols, was abandoned. Pakenham renewed the former proposal of Great Britain, that the line of forty-nine degrees be extended west from the Rocky Mountains to the Columbia, thence to the Pacific. Calhoun declined the offer, insisting that the United States had a well-founded claim to all the valley of the Columbia. In support of this assertion, he reviewed the history of the question in a long statement that rehearsed the earlier arguments of Adams, Rush, and Gallatin. Nothing was added by him to what his predecessors had said, but unlike them he confined his claim, not to all the territory up to fiftyfour degrees, forty minutes, but to the valley of the Columbia. ${ }^{12}$

Pakenham did not contend, as the representatives of Great Britain had formerly done, that all of the country north of forty-two degrees and west of the Rockies was vacant territory to which no nation had a perfect claim. He asserted that the Nootka Sound convention had limited Spain's sovereignty and acknowledged Great Britain's rights on the northwest coast. As the United States and Great Britain owned the country in common the only solution of the difficulty was "an equitable partition of the whole between the two powers." ${ }^{13}$ The long arguments of Calhoun and Pakenham left the matter no nearer an adjustment than it had been in I827. The United States continued to insist upon the line of forty-nine degrees; Great

${ }^{12}$ Calhoun to Pakenham, September 3, 1844; Correspondence relative. . . to the Oregon Territory, 13.

${ }^{13}$ Pakenham to Calhoun, September 12, 1844; ibid., 19. 
Britain claimed to the middle of the Columbia River. Aberdeen thereupon proposed arbitration. ${ }^{14}$ Pakenham delayed offering Aberdeen's proposal until after Tyler's message to Congress had been made public. The President renewed his recommendations for the establishment of military posts across the continent and the extension of the federal laws to protect the emigrants in Oregon. As to the pending negotiation little was said; he hoped for a happy and favorable termination of it in a manner "compatible with the public honor." ${ }^{15}$ In January Calhoun declined the offer of arbitration on the ground that such a method of settlement would retard rather than expedite its final adjustment. ${ }^{16}$ Thus Tyler's administration ended with the northwestern boundary question still at issue. It is probable that Calhoun had been dragged into the controversy against his better judgment. He was opposed to the plank in the Democratic platform of 1844 calling for the "re-occupation of Oregon." Tyler proposed to have the credit of accomplishing the settlement of the northwestern boundary question as well as of the annexation of Texas before his term expired. Calhoun made no attempt to claim any territory for the United States beyond the forty-ninth parallel. While he believed that by delay the Oregon country proper, $i$. e., the valley of the Columbia, would be saved to the United States, he reluctantly asserted the claim and then only to the line of forty-nine degrees.

${ }^{14}$ Aberdeen to Pakenham, November I, I844; ibid., 28.

${ }^{15}$ 'Tyler's message, December 3, I844; Richardson's Messages, IV., 337.

${ }^{16}$ Pakenham to Calhoun, January 15, I\$45; Calhoun to Pakenham, January 21, 1845 ; Correspondence relative. to the Oregon Territory, 30, 3I. 
Calhoun has been assailed as unfriendly to the interests of the northwest; as being, as a southerner, willing to sacrifice northern territory. Such a charge is unjust. Calhoun's attitude upon the Oregon question was deliberately chosen, and it was placed upon the plane of statesmanship, with no eye to popular approval. He believed that the British title under the Nootka Sound convention was a mere usufruct and conferred no exclusive claim; that the title of the United States as derived from Spain was invalid north of the Columbia valley. As far as claims were based upon discovery and occupation, the British had discovered and occupied Fraser's River and the Americans the Columbia; neither had a valid title to the country between the two. He was therefore in favor of the line of forty-nine degrees to the Pacific as a just and equitable division of the territory in dispute. ${ }^{17}$

In his inaugural address the incoming President stated that it would become his duty "to assert and maintain by all constitutional means the right of the United States to that portion of our territory which lies beyond the Rocky Mountains. Our title to the country of the Oregon is "clear and unquestionable." ", 18 Polk did not say that "the whole of Oregon" meant the country as far north as fifty-four degrees, forty minutes, although this was the interpretation given to his words. ${ }^{10}$ Calhoun had taken "the whole of Oregon" to mean the valley of the Columbia. It remained for Polk seriously to assert that our title was "clear and

${ }^{17}$ Polk's Diary, January ıо, I846; MS.

${ }^{18}$ Richardson's Messages, IV., 381. The phrase quoted was from the Democratic platform.

${ }^{10}$ Curtis, Buchanan, II., 552, so states it. 
unquestionable up to fifty-four degrees, forty minutes." Tyler's term closed soon after the rejection of Aberdeen's offer of arbitration. Soon after Buchanan took charge of the state department under Polk, Pakenham again urged that the Oregon matter be arbitrated. This was in accordance with Aberdeen's instructions, in the hope that the new administration might reverse Tyler's decision..$^{20}$ "Mr. Buchanan observed that he had not yet had an opportunity of ascertaining what might be the views of the President on this particular point connected with the Oregon question; but he said he would not fail to take advantage of the earliest moment to direct the President's attention to it. For his own part, although he did not seem to be much taken with the idea of an arbitration, he did not appear prepared altogether to reject it; what he said was that he did not at all despair of effecting a settlement of the question by negotiation, 'by adopting,' to use his own words, "the principle of giving and taking." "21 "To give and take" may have been Buchanan's idea of the proper method of negotiating with Pakenham. That he would settle the Oregon question was a part of Polk's programme as formulated by him before he was inaugurated. Not until July did the President decide how to proceed. Buchanan resumed the subject where Calhoun and Pakenham had dropped it in the preceding September by renewing the offer of the line of forty-nine degrees. Buchanan's note to Pakenham of July I2, I845, was a carefully prepared argument in favor of the full

${ }^{20}$ Aberdeen to Pakenham, March 3, 1845; Correspondence relative . . . to the Oregon Territory, 3I.

${ }^{21}$ Pakenham to Aberdeen, March 29, 1845; ibid., 32. 
American claim of fifty-four degrees, forty minutes. This he based upon the Florida treaty of 1819, at which time, he alleged, Spain had a good title as against Great Britain to the whole of the Oregon territory. As Great Britain had attempted to cloud this title by the prior Nootka Sound convention, Buchanan took the ground that that instrument was transient in its very nature; that it conferred upon Great Britain no right but that of merely trading with the Indians whilst the country should remain unsettled, and making the necessary settlements for that purpose; that it did not interfere with the ultimate sovereignty of Spain over the territory; and above all, that it was annulled by the war between Spain and Great Britain in 1796 , and had never been renewed by the parties. ${ }^{22}$ The original American title to the valley of the Columbia Buchanan grounded, as Calhoun had done, upon discovery, exploration, and possession. It was to the coast-line between forty-six degrees and fifty-four degrees, forty minutes, that the Florida treaty gave title to the exclusion of Great Britain. Buchanan thus took a position essentially at variance with Calhoun's. If the United States had a claim to the Columbia based upon discovery and settlement it was in derogation of the paper-title of Spain. If Spain's title to all of the northwest coast was not strong enough to withstand the claim of the United States to the Columbia, it was not sufficient to exclude Great Britain from claiming the Fraser River valley, a claim also based upon discovery, settlement, and possession.

Buchanan's contention was the reverse of Adams's,

${ }^{22}$ Buchanan to Pakenham, July 12, I845; ibid., 34 . 
which was that by the very terms of the Nootka Sound convention, which Buchanan held to be transient in nature, Spain had forfeited her claim to exclusive sovereignty upon the Pacific coast, so that the American settlements at the mouth of the Columbia furnished a claim of territorial sovereignty good as against the world. That Great Britain had a show of title between fifty-one degrees and fifty-five degrees had been admitted by the United States, since Adams had proposed a tripartite arrangement between the United States, Russia, and Great Britain in 1822 . Polk, however, intimated that he was not bound by any previous admissions by the United States. "Our own American title to the extent of the Valley of the Columbia, resting as it does on discovery, exploration, and possession,- - a possession acknowledged by a most solemn act of the British Government itself,-is a sufficient assurance against all mankind, whilst our superadded title derived from Spain extends our exclusive rights over the whole territory in dispute as against Great Britain. Such being the opinion of the President in regard to the title of the United States he would not have consented to yield any portion of the Oregon Territory had he not found himself embarrassed, if not committed, by the acts of his predecessors." ${ }^{23}$

Polk's offer of the line of forty-nine degrees without conceding the free navigation of the Columbia was, therefore, made only because his predecessors had committed him to it. The inference was that had he not been embarrassed by their spirit of compromise he would inflexibly adhere to the line of fifty-four degrees,

${ }^{23}$ Ibid. 
forty minutes, thereby excluding Great Britain from the Pacific coast.

Pakenham's answer was a blunder. $\mathrm{He}$ attacked all the points of Buchanan's argument and bluntly declined the proposed line of forty-nine degrees. $\mathrm{He}$ did not refer the matter to his home government but asked that Buchanan "offer some further proposal for the settlement of the Oregon Question more consistent with fairness and equity, and with the reasonable expectations of the British Government." ${ }^{24}$ Fortunately for the cause of peace, Pakenham's curt 1 efusal of Buchanan's offer did not become public until after Congress met in December. ${ }^{25}$ The answer was ill-considered in that it gave to Polk the oppor- / tunity of standing for the whole claim without being "embarrassed" by the admissions of his predecessors. "The only way to treat John Bull," the President told a member of Congress, "was to look him straight in the eye. I considered a bold and firm course on our part the pacific one." ${ }^{26}$ Buchanan was ordered to withdraw the offer of forty-nine degrees, leaving Great Britain to make the next move. The method of treating Pakenham's answer was Polk's own idea, and Buchanan was opposed to it. He wrote to McLane at London deprecating Pakenham's action and expressing the hope that the unfortunate result of it might be avoided. ${ }^{27}$ Buchanan's extended official reply to Paken-

${ }^{24}$ Pakenham to Buchanan, July 29, I845; ibid., 39.

${ }^{25}$ Curtis's Buchanan, II., 553, 554.

${ }^{26}$ Polk's Diary, January 4, 1846; Conversation with James A. Black of South Carolina. Polk added: "If Congress faltered or hesitated in their course, John Bull would immediately become arrogant and more grasping in his demands."

${ }^{27}$ Curtis's Buchanan, II., 553. 
ham of August 30, 1845, was contentious in the extreme. He derided the argument that the two grounds for the American title, the one based upon discovery and settlement, the other upon the treaty of I8I9, were antagonistic. The British claims were styled mere pretensions with no sufficient foundation. The President, he stated, owed it to his country, with a just appreciation of her title to the Oregon territory, to withdraw his proposition to the British government." "Mr. Buchanan said, 'Well, the deed is done, but he did not think it was the part of wise statesmanship to deliver such a paper in the existing state of our relations with Mexico.' The President said he was glad it was delivered; that it was right in itself and he saw no reason for delaying it because of our relations with Mexico." ${ }^{29}$

Writing privately to McLane, Buchanan said that the Oregon question was now critical ; that a conciliatory course on the part of both governments was necessary. He thought it improbable that the British government would offer acceptable terms of compromise, but said that the withdrawal of the offer did not preclude it from making a new proposal. He then stated that the President would submit to the Senate any proposition that Great Britain might make, if it were such as the Senate would be likely to approve. ${ }^{30}$ Before enough time had elapsed to have an answer to his letter, Buchanan received an account of McLane's

${ }^{28}$ Buchanan to Pakenham, August 30,1845 ; Correspondence relative . . . to the Oregon Territory, 46.

${ }^{20}$ Polk's Diary, August 30, I845; MS.

${ }^{30}$ Buchanan to McLane, September I3, I845; MS., copy, Lenox Library, New York. 
interview with Aberdeen upon the subject of Pakenham's declination of the line of forty-nine degrees. Aberdeen told McLane of his regret that Pakenham had rejected the offer of compromise, and intimated a willingness to agree to a modified proposition. ${ }^{31}$ After reading McLane's letter to Polk, Buchanan said that he believed Pakenham had received fresh instructions, and he wanted to know what to do. "The President said our course was a plain one. We had made a proposition which had been rejected in terms, not very courteous. The British had afterwards been informed in the note of Mr. Buchanan of August 30 that our proposition was withdrawn and no longer to be considered as pending. In the close of that note the door of further negotiations was left open. If the British minister, therefore, called on Mr. Buchanan and made the ingenuous (?) suggestion, all that could be said to him was: that if he had any further proposition to make on his part, it would be received and considered. This was all that could with propriety be said to him. No intimation should be given to him of what the views or intentions of the administration were, and leave him to take his own course. The President said, it was manifest that the tone of the British Government was considerably lowered on the subject. Mr. Buchanan said that if we stopped the negotiation where it was it would immediately lead to war. The President went on at some length to state, as he had done on former occasions, the reasons which had induced him in deference to the acts of his predecessors and the commitments of the Government reluctantly to yield

${ }^{31}$ McLane to Buchanan, October 3, 1845, received October 21, I845; MS., Archives. Polk's Diary, October 21, I845. 
his assent to the proposition which had been made and rejected and that he was never satisfied with the position in which the matter stood. He said if the same proposition were now made by the British minister (he, the President, having now discharged his duty) he would not accept it. He said the British minister would not, he was sure, make any new proposal which we could accept; that when his proposal was received (if he made one) he would either reject it or submit it to the Senate for their advice before he acted on [it] according to its character. Mr. Buchanan asked if he might say in the conversation which he anticipated Mr. Pakenham would seek with him, that if he made a proposition of a character to justify it, the President would submit it to the Senate. The President replied that would be improper. Mr. Buchanan thought we ought not to precipitate a crisis. By delay the Oregon territory might be saved; by strong measures hastily taken, we would have war and might lose it. The President said he was satisfied with the state of the negotiation as it stood; that in his message he would take bold and strong ground and re-affirm $\mathrm{Mr}$. Monroe's doctrine against permitting any European power to plant or establish any new colony on the American Continent." ${ }^{32}$ The day following Polk's statement to his cabinet Pakenham called upon Buchanan, who was impressed with his concern over the awkward position in which he had placed himself. ${ }^{33}$ From Buchanan's reports of this and other conversations with Pakenham, Polk continued in the belief that there was no probability of adjusting the subject

${ }^{32}$ Polk's Diary, October 21, I845; MS.

${ }^{23}$ Ibid., October 22, 1845. 
by negotiation. The President then submitted the clause of his message referring to the Oregon question and the Monroe doctrine to his cabinet, every member of which agreed with the stand that he had taken. It may be believed, however, that Buchanan's approval was not without reservation, for he still favored the idea that the negotiation should be resumed where it had been interrupted. ${ }^{34}$

At one of the conferences Pakenham left a note with Buchanan, in which he tried to smooth away the asperities of his earlier refusal. Pakenham stated that his government would be glad to hear again from the United States on the subject, and denied that in his earlie- letter he had rejected Buchanan's proposal. "What I said was that I did not feel at liberty to accept it." ${ }^{35}$ This may have seemed to be a distinction without a difference. Buchanan felt that it was enough of a concession to allow the negotiation to be resumed, and he prepared an answer to it accordingly. Polk declared that Buchanan's answer was too conciliatory and refused to have it delivered. ${ }^{36}$ The President then drafted what he believed to be a proper reply to Pakenham, with the injunction that it must be delivered and not merely read to the British minister, and that all of Pakenham's and Buchanan's correspondence must be official. Upon learning Polk's attitude, Pakenham withdrew his conciliatory note. For this the

${ }^{34}$ Ibid., October 25, 27, and 29, 1845.

${ }^{35}$ Pakenham to Buchanan, October 25, I845; MS., copy, Lenox Library, New York. Endorsed: "25 Oct. 45. Copy of a note from Mr. Pakenham, afterwards withdrawn. A true copy taken by me from the original note of Mr. Pakenham. Oct. 28, I845. J. Knox. Walker."

${ }^{36}$ Polk's Diary, October 28, 1845. 
President blamed Buchanan. "The result of the whole," Polk noted in his diary, "is that after two cabinet meetings and much anxious discussion, the matter ended where it began." ${ }^{\text {st }}$

Polk's discussion of the Oregon question in his message delivered at the opening of Congress was as "firm" as the most rabid of the Anglophobes, such as Cass and Hannegan, could have desired. He deprecated the early attempts at compromise with which the names of Adams, Rush, Gallatin, and Calhoun were associated. In his declaration for the "whole of Oregon," even to fifty-four degrees, forty minutes, he seemed to rejoice that a compromise line was impossible; as the American title to all of the northwest coast was clear and undisputed, Great Britain had then nothing but vain pretensions. To gain additional popular approval of his stand, he "re-affirmed" the Monroe Doctrine, with an eye, as he said, as much to California and the fine bay of San Francisco as to Oregon. ${ }^{3 s}$ Surely Polk was looking John Bull firmly in the eye. Was he sincere in his position?

It has been seen that nearly three months before Buchanan had written to McLane that the President would probably submit a proposition to the Senate if it were reasonable. Buchanan had not abandoned the idea that the line of forty-nine degrees could be agreed upon. It is hard to believe that Polk ever very seriously looked for war over the question of Oregon. Late in December Buchanan told him that the next two weeks would mean peace or war, and that he was in favor of vigorous war preparations. Polk agreed

${ }^{37}$ Ibid., October 29, 1845 .

${ }^{38}$ Ibid., October 24, 1845 . 
as to the latter part of Buchanan's remark. The cabinet was then expecting Pakenham to propose arbitration. None favored that plan of settling the difficulty. The President thereupon said that if Pakenham would offer an equivalent of free ports to the north of fortynine degrees, with the Strait of Fuca, he would "consult confidentially three or four Senators from different parts of the Union and might submit it to the Senate for their previous advice." ${ }^{30}$ At a later session Polk asked the cabinet what he should do if Pakenham offered the line of forty-nine degrees. "All said he should refer it to the Senate." 40 This was the advice that Polk had already received from Allen, the chairman of the Senate committee on foreign affairs. Just when this plan of treating the matter took shape in Polk's mind it is difficult to state precisely. There was no element of novelty in Allen's suggestion, for Buchanan had been urging it for months and he had privately so advised McLane.

Just at this time Pakenham proposed that arbitration be had of "the whole question of an equitable division of the territory" in dispute. "1 Buchanan said to him that even if the President agreed to arbitration, which was unlikely, the Senate would never sanction it. That there would be a war Pakenham seemed to doubt, for even if arbitration were finally declined, his govern-

30 Ibid., December 23, I845. Curtis's Buchanan, II., 555. McLane to Buchanan, December I, I845, stated that Aberdeen favored arbitration.

${ }^{40}$ Polk's Diary, December 27, 1845 .

${ }^{41}$ Pakenham to Buchanan, December 27, 1845; Correspondence relative . . . to the Oregon Territory, 65. Curtis's Buchanan, II., 556. 
ment would let the affair remain where it was and not disturb it. "He said the British Government would be glad to get clear of the question on almost any terms; that they did not care if the arbitrator should award the whole territory to us. They would yield it without a murmur. I said I had no doubt of it. They never played the part of the fox; but always of the lion. They would preserve their faith inviolate. $\mathrm{He}$ said they wished for peace; but intimated this was not our wish. I asked him why we should desire war. Would not their superiority at sea give them command of the Coasts of Oregon? Yes, he said, that was true, but the war would not be confined to that region. That he would willingly make a bargain to fight it out with us there, if we would agree to that." ${ }^{2}$

Buchanan declined Pakenham's proposal for arbitration. The British minister renewed the offer, this time agreeing to include the question of title. ${ }^{43} \mathrm{Bu}$ chanan replied that the United States would arbitrate no question involving its territorial rights."

To McLane the secretary of state now opened the door for the British government to come forward with a compromise proposition. The President would never put it into the power of any arbitrator to deprive the United States of a "foot of the soil of the continent south of the forty-ninth parallel of latitude, and of the valuable harbors of Puget Sound." He thought likely that Congress would order notice to be given, and therefore if the British government had a proposition

${ }^{42}$ Buchanan's memorandum, Curtis's Buchanan, II., 557

${ }^{43}$ Pakenham to Buchanan, January 16,$1846 ;$ Correspondence relative . . . to the Oregon Territory, 67.

${ }^{4}$ Buchanan to Pakenham, February 4, I846; ibid., 69. 
it should be made at once. "They have not an hour to lose if they desire a peaceful termination of this controversy." " Even while McLane reported that Great Britain was making extensive preparations for war, Polk felt that Peel and Aberdeen, like Pakenham, were for peace. ${ }^{46}$ Polk gave it out that his own desire was to stand for fifty-four degrees, forty minutes, but that he would refer any suitable proposition to the Senate. Thus Aberdeen was given to understand that the President would not reject an offer to settle upon the line of forty-nine degrees. Later despatches to McLane put forth this idea more definitely. McLane suggested that Aberdeen would probably propose that line. Polk consented, although "with reluctance," to subnit it, if made, to the Senate, but he stipulated that the negotiation should not be transferred to London. Thus the two powers were as early as February, 1846, not far apart. McLane was certain that Aberdeen was willing to agree to the line of forty-nine degrees. Polk was willing to submit such a compromise to the Senate, knowing that the Senate committee on foreign affairs would favor it. From this time until June, when the treaty was finally signed, there was no serious danger of any rupture. The speeches in Congress, it is true, were full of belligerency, but the resolutions for the abrogation of the joint-occupation convention were so amended that they lost all character likely to embarrass the peaceable settlement of the question. Polk was authorized in his discretion to give the necessary notice, which he did April 28. With

${ }^{4}$ Buchanan to McLane, January 29, 1846; Cong. Globe, Appendix; 29 Cong., I Sess., II75.

${ }^{48}$ Polk's Diary, January Io, I846. 
the copy of the notice sent to McLane, Buchanan invited the British government to make a proposal for the settlement of the question. The rest of the negotiation was really the formal carrying out of what each government already knew the other would agree to. Upon the receipt of Polk's notice that the convention of 1827 was abrogated, Aberdeen formally instructed Pakenham to offer the line of forty-nine degrees to the Pacific, reserving to Great Britain, however, the whole of Vancouver Island and the free navigation of the Columbia. ${ }^{47}$

Aberdeen's offer came directly after the repeal of the Corn Laws had passed the House of Commons. ${ }^{48}$ Within a few days after the Corn Bill became a law, Peel's ministry resigned and Aberdeen went out of office. Pakenham proceeded at once with the negotiations as instructed by Aberdeen. On the fifteenth of June he and Buchanan signed a convention substantially on the lines that Aberdeen had outlined to McLane. The line of forty-nine degrees extended to the Pacific; the whole of Vancouver Island remained in Great Britain's hands and the free navigation of the Columbia was conceded. Before the treaty was signed, Polk stated to the Senate that his own opinions upon the Oregon question remained as they had been expressed in his annual message. It was a wise plan, he stated, which Washington had adopted, of asking the previous advice of the Senate upon pending negotiations. A matter of such magnitude as

${ }^{47}$ McLane to Buchanan, May I8, I846; Cong. Globe, Appendix; 29 Cong., I Sess., II7o.

${ }^{48}$ The Corn Bill passed the House of Commons upon third reading May 15. The Lords passed it June 25. 
the Oregon question, upon the decision of which hung peace or war, was in his judgment very properly left to the Senate, not only as a part of the treaty- but of the war-making power." The Senate with but little debate resolved that the President was "advised to accept the proposal of the British Government." so Thus he evaded all responsibility for the compromise line. He made it appear that the proposal for such a settlement came wholly from Great Britain. It was true that the official proposal did so come, but not until Polk had let it be understood by Aberdeen and Pakenham that he would not reject it. He cast upon the Senate the responsibility for the compromise, warning them, however, that its rejection might mean war.

Polk had looked John Bull firmly in the eye, and John Bull proposed what he had so often refused. But was Polk's firmness the cause of the peaceful and fair settlement? Had Palmerston been in Aberdeen's position at the time of Polk's "firm" pronouncement, Polk might have lost Oregon. That the Oregon question was settled in the manner it was is one of the glories of the administration of Sir Robert Peel. Aberdeen's large-mindedness and consistent belief that the friendship of the United States was worth much more to Great Britain than a few degrees of latitude on the Pacific coast are responsible for the settlement that Polk thought to gain by a firm policy. That Aberdeen was "bluffed" by Polk is absurd. Peel knew that he could not retain office after the repeal of the Corn

${ }^{40}$ Polk's message, June Io, 1846; Richardson's Messages, IV., 449.

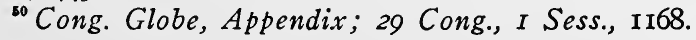


Laws, and it was the part of great statesmanship not to leave to his successors in office an impasse that had been brought about during his administration. Peel could not go into opposition with a war of his own creation upon his hands. He would not aggravate the warlike feelings of England for the purpose of maintaining his hold upon office. McLane was correctly advised of Peel's attitude when Aberdeen sent Pakenham his instructions to propose the compromise line. He wrote to Buchanan that Peel's ministry would resign before the end of June, and that in case the new proposal were not accepted promptly, the new ministry might not agree to as favorable terms. ${ }^{51}$ Upon the day that the Peel administration resigned, news came that the United States had agreed to Aberdeen's offer of settlement, and the second great boundary controversy with the mother-country was at an end.

In all the history of the relations of the United States with Great Britain no Englishman showed himself to be a better friend to the United States than did Lord Aberdeen in his handling of the Ashburton and Pakenham negotiations.

${ }^{81}$ McLane to Buchanan, May I8, I846; ibid., II70. 


\section{CHAPTER XI}

Polik's Attempted Negotiation for California

$$
\text { I } 845-1846
$$

The most important source of information for the administration of President Polk is unfortunately still in manuscript. In the library of the Chicago Historical Society is a set of small note-books in which James $\mathrm{K}$. Polk entered from day to day his comments upon the measures and men of his time. Beginning in August, I845, the diary continues without a break until he left public life. George Bancroft, whose association with Polk was intimate, first as secretary of the navy and afterwards as minister at the Court of St. James, would, had life and mental vigor permitted him, have been the historian and perhaps the apologist of the administration in which he played so conspicuous a part. In the Lenox Library at New York is a manuscript copy of Polk's diary made under the direction of Bancroft. In addition to the originals of the diary, the Chicago Historical Society owns a number of letters to and from Polk. A large collection of Polk's correspondence, in all over ten thousand letters, has recently been acquired by the Library of Congress. Of these much is related to the years 1845 to 1849 . Thus the material for a study of Polk's administration is enormous, but being divided among the libraries of Washington, New York, and Chicago and still unprinted, it is unfortunately somewhat difficult of access. The writing of a life of Polk and of a history of his administration based upon the mass of unpublished mat- 
ter connected with it is a labor yet to be accomplished. The history of the diplomatic events of this administration also rests largely upon unprinted material. Those portions of the official correspondence printed at the time can be found only in the executive documents of the Senate and House, which, buried in government publications, rather difficult to obtain, may be said to have been printed and not published. The fragments so printed are but a small part of the letters and instructions to be found in the department of state. The same may be said of the naval and military history of the Mexican War. It is believed that no one has ever examined all of the records of the war and navy departments from 1845 to 1849 for the purposes of historical investigation. The best history of the war is Ripley's, written soon after the war closed. As to the Mexican sources upon the war, it is to be hoped that before long a report will be made as to their completeness and accessibility.

The reasons for the lack of published materials for Polk's administration are obvious. The results of Polk's policy, namely, the conquest of New Mexico and California, gave rise to such a rapid succession of political events ending in civil war that public attention was drawn away from the causes to the consequences of the Mexican War. Polk's administration had no apologists but many vehement critics. The dominating influence of slavery left the Mexican War as a mere incident in the history of the larger question.

The history of the Mexican War, therefore, aside from the purely military part of it, has been written chiefly as a chapter in the history of the slavery question. The momentous national issues that pressed 
for attention even before Polk retired from office have given a twist to the many accounts of the period from I 845 to 1848 . Books appearing soon after the event, animated not by a spirit of unbiased historical investigation, but written with the professed purpose of presenting a brief against the aggressions of slavery, have furnished in large measure the materials for the history of the period. The treatment of the subject of the Mexican War in the "reviews" of Jay ${ }^{1}$ and Livermore," well constructed and widely distributed as they were, and fortified by an examination of published documents and newspapers, has grown into the narrative of Von Holst.

Polk came into the presidential chair with a welldefined programme. It was, in the main, not one dictated to the President by his party nor was it formulated for him by his political associates and advisers. His mind alone gave form to the last part of it, and four years saw it accomplished. This programme was: ( I) the reduction of the tariff; (2) the establishment of the subtreasury; (3) the settlement of the Oregon question, and (4) the acquisition of California. This was a large task to be performed in four years, but the accession of the Whig party to power found it completed. "Who is Polk?" had been the sneer of his political adversaries of I 844 . The question was sufficiently answered when he left office.

At the time of Tyler's retirement diplomatic relations with Mexico had been suspended. Almonte, the Mexi-

${ }^{1}$ William Jay, $A$ Review of the Causes and Consequences of the Mexican War (Boston, I849).

${ }^{2}$ Abiel Abbot Livermore, The War with Mexico Reviewed (Boston, I850). 
can minister at Washington, surrendered his passports to the secretary of state, accompanying his note of leave-taking with an angry review of the alleged hostile attitude of the United States toward his country, as shown by the annexation of Texas. Meanwhile, Wilson Shannon, our minister to Mexico, had demanded his passports from Rejon, the minister of foreign relations. Shannon's predecessor, Thompson, had pursued the same course but had calculated correctly that the request would not be granted. It was otherwise with Shannon; Rejon gave him his passports and accompanied them with a fierce denunciation of the policy of the United States toward Mexico.

There is a characteristic vein running through the diplomatic correspondence of Spanish-speaking envoys, from D’Yrujo to De Lome. However much pride and vainglory one may see in it, there has been little hypocrisy. In the communications to Gorostiza, Almonte, and Rejon, both official and unofficial, invective, accusation, and abuse were set forth in terms hardly diplomatic. On our side there was as well a continuous alternation of threat and lecture. The only basis for successful diplomatic negotiation, which rests upon a thorough knowledge and appreciation of the Spanish character, was conspicuously lacking.

Polk lost no time after his inauguration in making plans for carrying out the fourth item of his scheme. The stipulation in the Texas joint resolution, which left the adjustment of the boundaries of Texas to the United States, gave him his opportunity, and he grasped it at once. Almonte left New York for Mexico April 3, 1845. The same ship carried an agent secretly sent by the President to make an effort to reopen dip. 
lomatic relations with the Mexican government. This secret agent was Dr. William S. Parrott, who had practised dentistry some years previously in the City of Mexico. He had afterwards engaged in business there and had failed, one of his assets being a claim against the Mexican government, though of this claim Polk, at the time of Parrott's appointment, probably knew nothing.

The instructions given Parrott were to reach the president and other high officials of the Mexican government and by every honorable means to convince them that it was the true interest of their country to restore friendly relations between the two republics; not until he had definitely ascertained the willingness of Mexico to receive an envoy from the United States was he to disclose his own official character. "Whilst you ought not to conceal that the re-union of Texas with the United States is already decreed and can never under any consideration be abandoned, you are at liberty to state your confident belief that in regard to all unsettled questions, we are prepared to meet Mexico in a liberal and friendly spirit." No specific instructions were given as to the mode of proceeding. "Should you clearly ascertain that they are willing to renew our diplomatic intercourse, then, and not till then, you are at liberty to communicate to them your official character and to state that the United States will send a minister to Mexico as soon as they receive authentic information that he will be kindly received." 3

The selection of William S. Parrott as an agent for

${ }^{3}$ Buchanan to Parrott, March 28, I845; MS., Archives. 
the reëstablishment of diplomatic relations was a strange one. Parrott had urged his claims against Mexico for a lot of English ale in a manner that disgusted Thompson, as the records of the state department would have shown. Thompson's comment upon Parrott's claim was that it had grown more enormously than "Jonah's gourd." " Polk and Buchanan, probably ignorant of the matter, selected Parrott because he had lived long in Mexico and professed an intimate knowledge of and acquaintance with its leading men. The agent reached Mexico before Shannon left. His official character was an open secret, and although he was persona non grata to the government on account of his claim, he was permitted to remain after Shannon had departed. Parrott complained to Buchanan that British influences prevented him from approaching the members of the Herrera government. From the first he dwelt upon the strength of British influence and the danger of Great Britain's seizure of Upper California. ${ }^{5}$ Judging from his correspondence, he seems to have relied largely upon the newspapers for his information." At first without even a "letter of security," which Black, the consul at Mexico, had unsuccessfully requested for him, and fearful each day of expulsion, Parrott managed early in June to get into "indirect" communication with the government." He reporied that no one believed that war would be declared against

"Parrott's claim of $\$ 986,880$ was reduced to $\$$ II 4,750 by the award. MS., Awards, II., 45; Department of State.

${ }^{5}$ Parrott to Buchanan, May I3, I845 (received July 2); MS., Archives.

- Parrott to Buchanan, May 30, I845; MS., Archives.

'Parrott to Buchanan, June 10, I845; MS., Archives. 
the United States on account of Texas. "The presumption and folly of this people are great, it is true, but hardly enough so to force the administration to adopt a measure which if persisted in might erelong endanger the nationai existence of their country." Parrott's disposition, however, was not that of a peacemaker. "Nothing but a severe chastisement," he wrote, "would secure our people in future."

The cabinet of Herrera, which had been loosely held together, was reconstructed in August. Parrott reported that the new cabinet was in accord with Herrera and that no war would be waged on account of Texas. "There is a desire, even publicly manifested, to receive a commissioner from the United States and every vessel that arrives at Isla Verde is said to have one on board. I have reason to believe that an envoy from the United States would not only be well received, but his arrival would be hailed with joy. An Envoy possessing suitable qualifications for this Court might with comparative ease settle over a breakfast the most important national question, while such as we have lately had here would make matters worse." 10

Polk had no intention of returning Shannon. Ten days after the letter just quoted was received from Parrott, Polk instructed Buchanan to write to John Slidell of Louisiana, who had previously been offered and had accepted the Mexican mission, that he should

${ }^{3}$ Parrott to Buchanan, July I2, I845 (received September I); MS., Archives.

' Parrott to Buchanan, July 26, 1845 (received August 25) ; MS., Archives.

${ }^{10}$ Parrott to Buchanan, August 26, 1845 (received September I6) ; MS., Archives. 
hold himself in readiness to leave for his post upor one day's notice."

On that date, the diary informs us, the Presiden announced clearly to his cabinet that he would try to adjust through this Texas question a permanent boun. dary between Mexico and the United States so as to comprehend Upper California and New Mexico anc to give us a line from the mouth of the Rio Grande to latitude thirty-two degrees north and thence wes to the Pacific. For such a boundary he was willing tc pay, he said, forty million dollars, but he could prob. ably get it for fifteen or twenty millions. In these views the cabinet unanimously concurred. The ap pointment of John Slidell followed quickly upon this decision of the cabinet.

Slidell, upon whom the strictest secrecy concerning his appointment was enjoined, replied that it was beyond belief that the Mexican government would sc soon receive a diplomatic representative from the United States. ${ }^{12}$ He felt, as had Polk and his cabinet that no one would dare make any overtures pending the election of the president of Mexico, which was soon to take place. Parrott's reports, however, although corroborated by Black and Dimond, consuls at Mexico and Vera Cruz respectively, did not fully convince the President that Herrera, the president ad interim, who was now reëlected, was not trying to win political capital by warlike threats against the United States. $^{13}$

${ }^{11}$ Polk's Diary, September 17, 1845.

${ }^{12}$ Slidell to Buchanan, September 25, I845; Curtis's Buchanan, I., 59I.

${ }^{13} \mathrm{Cf}$. Curtis's Buchanan, I., 588. 
What Parrott had done was, however, no secret in Mexico. On November I, El Amigo del Pueblo, a Mexican newspaper, denounced the government of Herrera as engaged in a "horrible treason." "This vile government," it said, "has been and is in correspondence with the usurpers. The Yankee Parrott and the American consul at Mexico are those who have agreed with the government for the loss of Texas, and this same Parrott has departed for the North to say to his government to send a commissioner to make with our government an ignominious treaty on the basis of the surrender of Texas and we know not what other part of the republic. This is as certain as the existence of God in Heaven." The article proceeded in scurrilous fashion to characterize Parrott as a shameless sharper and adventurer, concluding with the statement that Parrott had himself disclosed these secrets on the eve of his departure. From Commodore Conner, commanding the naval forces in the Gulf, came despatches stating that Mexico was willing to renew diplomatic relations and to receive a minister from the United States. ${ }^{14}$ The cabinet thereupon unanimously agreed to Slidell's instructions. ${ }^{15}$

Parrott's work in Mexico was completed by October I8, when he left for Washington with a note from Black, the American consul, which stated that he had positive and official assurance that the Mexican ministry was favorable to an adjustment of the questions in dispute between the two republics. The cabinet had agreed that Slidell's formal appointment should be de-

${ }^{14}$ Polk's Diary, November 6, I845.

${ }^{15}$ Ibid., November 7, 1845 . 
layed until some official assurances should be had that Mexico would receive an envoy, and Black was asked to procure them. Parrott arrived at Washington November 9. Upon the tenth Buchanan sent Slidell his instructions, which had been drafted seven weeks before. ${ }^{16}$ These instructions to Slidell are of fundamental importance in rightly understanding Polk's policy toward Mexico. The President told Bancroft soon after the inauguration that the acquisition of California would be one of the main objects of his administration. Slidell's appointment was a secret. Every precaution was observed by Polk to keep his instructions from becoming public. While confidential instructions may have been given Slidell before he left Washington in the spring, yet Buchanan's instructions to him are the official expression of Polk's policy toward Mexico, and these were consistently adhered to. That Polk so considered them is proved by the fact that they accompanied the instructions of Commissioner Trist a year and a half later, and that they were given official publicity only when the final treaty was submitted to the Senate for ratification. When the House called for them Polk stood upon his constitutional prerogative and refused to make them public, claiming that to do so "could not fail to produce serious embarrassments in any future negotiation between the two countries." This was as late as January I2, I848, more than two years after the instructions had been drafted, and when the war was practically at an end. The cabinet agreed with Polk that Slidell's instructions should be kept

${ }^{16}$ Ibid., September 22, I845. 
secret "because the French and British ministers might try to thwart or defeat the objects of the mission.",

Parrott's mission and Slidell's instructions taken together prove two things: (I) that the Mexican War was not the result of the annexation of Texas, and (2) that the reopening of diplomatic relations with Mexico was for the purpose of securing California by purchase. These instructions are the key-note to Polk's aggressive policy of expansion. The President developed a plan by which he believed that expansion could be effected by peaceful means. Claims against Mexico, under discussion as far back as Jackson's time, furnished the groundwork of the plan; the joint resolution annexing Texas gave the President something to build upon. Mexico could not pay the claims in cash; the Texan boundary was unsettled. The idea of territorial indemnity was an irresistible conclusion: let her pay in land.

The instructions to Slidell first dwelt upon the reported designs of European countries upon Mexico, a subject which ever afforded an opportunity for decided statement. Buchanan then said that the claims of American citizens upon Mexico would first engage Slidell's attention as matters yet unsettled by the unratified treaty of 1843 . As Mexico was not in a position to settle these claims in money, the United States must assume them. The plan of doing this is then developed. "Fortunately," Buchanan said, "the joint resolution of Congress, approved March I, I845, for annexing Texas, presents the means of satisfying these claims in perfect

${ }^{17}$ Ibid., September 16, 1845. 
consistency with the interests as well as the honor of both republics" by the reservation therein to the United States of the right to adjust all questions of boundary that might arise between it and Mexico. The Rio Grande boundary was then discussed, and as to it, Buchanan said, "there can be no serious doubt," based upon the independence of Texas as a fact not to be called in question. New Mexico, on the other hand, presented a different question, as it had never been conquered or taken possession of by the Texans. In case Mexico should agree to fix the boundary from the mouth of the Rio Grande up the middle of the principal stream to the point where it touches the line of New Mexico, thence west and north to the fortysecond parallel, so as to include the whole within the United States, then this country would assume the payment of her citizens' claims against Mexico and would pay five millions in addition. The cession of Upper California was the next topic considered. This province, said Buchanan, was already practically lost to Mexico and coveted by Great Britain and France. "If you can obtain a cession of it," the secretary said, "you will render immense service to your country and establish an enviable reputation for yourself. Money would be no object when compared with the value of the acquisition." For it he might offer twenty-five millions, in addition to the assumption of the claims, or five millions less if the southern line was north of Monterey but included the Bay of San Francisco. Such was the difficult errand upon which John Slidell went to Mexico; as his instructions stated, it was "one of the most delicate and important missions which had ever 
been confided to a citizen of the United States." "The people to whom you will be sent are proverbially jealous; and they have been irritated against the United States by recent events and the intrigues of foreign powers. To conciliate their good will is indispensable to your success. It would be difficult to raise a point of honor between the United States and so feeble and distracted a power as Mexico." ${ }^{18}$

Polk's disposition of the military and naval forces of the United States was in thorough accord with his diplomatic policy. In May, I845, Taylor was ordered to cross the Sabine into Texas to protect it pending annexation. Taylor proceeded to advance as far as Corpus Christi. Jones, the president of Texas, claimed that Donelson, together with Captain Stockton, commanding the naval forces upon the coast of Texas, attempted to dragoon him into demanding a strong concentration of United States forces, naval and military, upon the western border of Texas in anticipation of war between Mexico and the United States. Jones even went so far as to state that it was evidently the determination of Donelson and Stockton to force a war with Mexico for the purposes of further territorial aggrandizement. He threw upon Taylor the responsibility of his advance to Corpus Christi, claiming that Texas was not seriously menaced. ${ }^{10}$

Whatever may have been the individual activities of Polk's agents, the President did not proceed to force Mexico into a war. Polk worked for peace, but at the same time prepared for war. If war resulted, the conquest of California should be its fruit.

${ }^{18}$ Buchanan to Slidell, November 1o, 1845; S. Ex. Doc. 52, 30 Cong., I Sess., 7 r.

'Jones, Official Correspondence, passim. 
The gulf squadron under Conner was ordered to blockade Vera Cruz in the event of war and to develop the fortifications of San Juan d' Ulloa. ${ }^{20}$ The naval forces in the Pacific under the command of Commodore Sloat were reinforced by parts of the Mediterranean and East India squadrons. ${ }^{21}$ Sloat was ordered, in case he should hear of hostilities between the United States and Mexico, to seize San Francisco at once, together with such other Pacific ports as his forces would permit. In case war did not occur his squadron was to cruise along the coast of California to Oregon, "to cheer our citizens in that region by the presence of the American flag." ${ }_{22}$

At Monterey, Thomas O. Larkin, the foremost American merchant there, had for some time performed the slight duties of the consular office. During the summer of 1845 Buchanan received from him reports upon the political conditions of California; the consul reported that the population was apathetic and even disloyal to Mexico, and that Great Britain and France had evident designs upon the province. ${ }^{23}$ Lieutenant Archibald H. Gillespie of the marine corps was despatched to Monterey to get into communication with Larkin. Gillespie's instructions were secret. No copy of them has been found in the navy department,

${ }^{20}$ Bancroft to Conner, "confidential," August I6, I845; August 30, I845, "secret;" MS., Archives, Navy Department.

${ }^{21}$ Bancroft to Commodore Smith, May 13, I845; Bancroft to Parker, June 24, 1845; MS., Archives, Navy Department.

${ }^{22}$ Bancroft to Sloat, June 24, I845; H. Ex. Doc. 60, 30 Cong., I Sess., 231.

${ }^{23}$ Larkin to Buchanan, June 6, I845 (received September Ió) and July Io, I845 (received October II); MS., Archives. 
and the precise nature of them cannot be determined. ${ }^{2}$ After a dangerous trip through Mexico, in the course of which he was forced to destroy all of his papers, the lieutenant arrived in Monterey in April, I846, just as active hostilities with Mexico began. ${ }^{25}$ Gillespie had been sent upon his errand November I, I845. Shortly before this Stockton, who had been appointed to the command of the Pacific squadron, was instructed to sail under sealed orders to the Sandwich Islands and thence directly to Monterey, California. "You will confer with the consul, gain all the information you can on Mexican affairs and do all in your power to conciliate the good feelings of the people of that place toward the United States." ${ }^{28}$ To Stockton was entrusted Buchanan's letter to Larkin, a copy of which Gillespie took at the same time. ${ }^{27}$ The policy of Polk in reference to the acquisition of California was therein outlined.

"In the contest between Mexico and California we can take no part unless the former should commence hostilities against the United States; but should California assert and maintain her independence, we shall render her all the kind offices in our power as a sister

${ }^{24}$ Polk's Diary, October 30, I845. Bancroft to Gillespie, November I, I845. Gillespie received orders April 26, I843, November I, I845, and April 23, 1846. None contained instructions relative to this errand. MS., Archives, Navy Department.

${ }^{25}$ Larkin to Buchanan, April I7, I846; MS., Archives.

${ }^{26}$ Sealed orders to Stockton (not to be opened until he passed the Capes), October I2, I845; MS., Archives, Navy Department.

${ }^{27}$ Gillespie committed to memory the contents of Buchanan's letter to Larkin, and destroyed the copy upon his arrival at Vera Cruz. 
republic. This government has no ambitious aspirations to gratify and no desire to extend our federal system over more territory than we already possess, unless by the free and spontaneous wish of all the independent people of adjoining territories. The exercise of compulsion or improper influence to accomplish such a result would be repugnant to both the policy and principles of the government. But whilst these are the sentiments of the President, he could not view with indifference the transfer of California to Great Britain or any other European power. . . The true policy for the present in regard to this question is to let events take their own course, unless an attempt should be made to transfer them [i.e., the people of California] without their consent to Great Britain or any other European power. . . . Lieut. Archibald $\mathrm{H}$. Gillespie of the marine corps will immediately proceed to Monterey and will probably reach you before this despatch. He is a gentleman in whom the President reposes entire confidence. He has seen these instructions and will coöperate with you in carrying them into execution." ${ }_{28}$

Thus while Polk upon the one hand awaited official assurances from Mexico that she would peacefully reëstablish diplomatic relations with the United States, upon the other he signified that he would aid in the dismemberment of Mexico. The expeditions of Frémont are beyond the scope of the present narrative, but it may be stated here that the instructions to Larkin, the secret mission of Gillespie, and the exploits of Frémont are parts of one and the same policy: if peace

${ }^{23}$ Buchanan to Larkin, October 17, I845; MS., Ar hives. 
continued with Mexico, to attempt to purchase California ; if purchase failed, to assist California to throw off the Mexican yoke. The instructions to Larkin and Stockton can be read in no other light. Events, however, moved in a different channel. War and not peace followed. California became part of the United States through conquest.

John Slidell's appointment was as envoy extraordinary and minister plenipotentiary to Mexico. Upon the capacity in which Slidell presented himself at Mexico turned the question of his reception. The point was that while Mexico might be willing to receive from the United States a commissioner ad hoc to treat concerning the question over which there had been a rupture of diplomatic relations-namely, the annexation of Texas to the United States-it was a totally different matter for her to receive a regular minister to take up the usual diplomatic functions of the legation. A commissioner would be instructed to settle one definite dispute and the matters collateral to it. The reception by Mexico of a minister would open the door to the general course of diplomatic negotiations upon which the American minister might be instructed. Again, Mexico as a matter of pride would hesitate to receive a minister, thus acknowledging her announcement, that annexation was equivalent to war, to be a vain and empty threat. So far as Polk and Buchanan were concerned they would not have sacrificed any national self-respect had a commissioner been sent instead of an envoy. The boundary between Texas and Mexico, since the action of the Texan congress and convention, was unsettled. It had purposely been left so by the joint resolutions of annexation. Why Polk 
and Buchanan insisted upon sending a minister is a matter of conjecture. As far as Parrott's letters reported upon the reception of a representative, reference is made to a minister or to an envoy. Polk used the same expression in his diary, though he must have known of the doubts expressed at Washington of the reception of a representative with such general functions. ${ }^{29}$ Mexico's attitude toward Slidell turned upon this one point, which was seized upon as soon as the purport of his instructions became known to Herrera's government. How these secret instructions leaked out is not known.

Slidell arrived at Vera Cruz late in November and proceeded at once to the City of Mexico. Parrott, who had been appointed secretary of legation, followed him in company with Gillespie, en route with despatches for Larkin at Monterey.

Slidell's arrival at the City of Mexico evidently embarrassed Herrera, whose government, never a strong one, was beginning to fear a revolution against it. Peña y Peña, the secretary of foreign affairs, told Black that Slidell was not expected until January, and that if "Mexico received a commissioner" now it would endanger the government. ${ }^{31} \mathrm{He}$ positively refused to receive Parrott as secretary of legation. The enemies of Herrera were strong and immediately used Slidell's arrival as political capital against the existing administration. As soon as Slidell reached Mexico broad-

${ }^{20}$ Tyler's Tylers, III., I76; statement of Benjamin E. Green.

${ }^{30}$ Slidell to Buchanan, December 17, 1845; postcript. MS., Archives. Parrott to Buchanan, December II, I845; MS., Archives.

${ }^{31}$ Black to Buchanan, December 18, I845; S. Ex. Doc. 337, 29 Cong., I Sess. 
sides appeared over the city and told of his plans: to negotiate with Herrera's government for the sale of Texas, New Mexico and the Californias. The reception of Slidell by Herrera, said the broadsides, would be an act of treason.

Slidell's despatch, which enclosed one of these handbills, was received in Washington January $\mathrm{I} 2$, 1846 . Taylor was ordered forward from Corpus Christi to the Rio Grande the following day. ${ }^{32}$ Thus the refusal to receive Sliclell in his capacity as minister was taken as sufficient grounds for the occupation of the country beyond the Nueces. Slidell, however, did not believe that his rejection was final. Bankhead, the British minister, was requested by Peña y Peña to state to Slidell "that the government had in its present critical position, feared to compromise themselves by receiving him, that had they been free to act they would have pursued a different course, and that, should they succeed in putting down the movements of Paredes, they would take the necessary steps to bring about a renewal of diplomatic relations."

Buchanan supplemented Slidell's instructions by stating that the President desired the negotiations brought to a conclusion with as little delay as possible. "He desires to submit the result to Congress before the termination of the approaching session, so that, in the event of a failure, prompt and energetic measures may be adopted on our part to redress the injuries which our citizens have sustained from Mexico." "st If

${ }^{32}$ Polk's Diary, January I3, I846.

${ }^{33}$ Slidell to Buchanan, December 29, 1845 (received January 23, I846) ; MS., Archives.

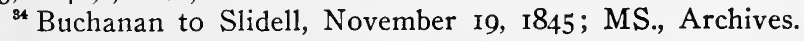


Slidell succeeded in concluding a treaty upon the lines of his instructions, he was to have it ratified by the Mexican government before its transmission. to the United States. After the receipt of Slidell's first letter, in which he reported that Herrera declined receiving him immediately, Buchanan advised him of the orders to Taylor and to the gulf squadron, which was to rendezvous before Vera Cruz. "Should war become inevitable, the President will be prepared to conduct it with vigor." ${ }_{35}$

The revolution under Paredes gained headway, and soon the government of Herrera was overthrown. Paredes was as belligerent as Herrera had been peaceable. Slidell, however, continued to feel assured that the new government would receive him. He waited until the middle of March, hoping each day that Paredes would direct that he be received. His expectations were in vain. The new minister of foreign affairs sent Slidell his passports and definitely refused to receive him. "Be assured," wrote Slidell to Buchanan, enclosing Castillo's refusal, "that nothing is to be done with these people until they shall have been chastised." ${ }^{37}$

Polk, however, had long since made up his mind to "chastise" Mexico. The Oregon negotiations presented one obstacle to the immediate carrying out of his plans. The danger of having two wars on hand

${ }^{35}$ Buchanan to Slidell, January 20, I846; S. Ex. Doc. 337 , 29 Cong., I Sess., 44.

${ }^{38}$ Castillo y Lanzas to Slidell, March I2, I846; Slidell to Castillo y Lanzas, March 17, 1846; ibid.

${ }^{37}$ Slidell to Buchanan, private, March 15, 1846 (received April 17, "night"); MS., Archives. 
was grave enough to delay active measures against Mexico, although at no time did Polk seem seriously to fear a rupture with Great Britain on account of Oregon. It was apparent that Sliclell's mission was a failure. California was not to be purchased as the result of a negotiation upon the claims and the Texas boundary. The next step was to be an openly aggressive movement against Mexico. Until the Oregon question was out of the way, Polk wanted Slidell to temporize and not finally to close the door to negotiation. Instead of calling Slidell home, he was ordered to make further efforts to obtain recognition. Buchanan wrote Slidell, March I2, I846: "The Oregon question is rapidly approaching a crisis. By the steam packet which will leave Liverpool on the $4^{\text {th }}$ of April, if not by that which left on the 4th instant, the President expects information which will be decisive on the subject. The prospect is that our differences with Great Britain may be peacefully adjusted, though this is by no means certain. Your return to the United States before the result is known, would produce considerable alarm in the public mind and might possibly exercise an injurious influence on our relations with Great Britain." ${ }^{38}$

Slidell, who had previously no intimation that his mission had any connection with the Oregon negotiation, was on his way home when Buchanan's last letter reached him. "Had such a hint been given to me there could have been no difficulty in procrastinating indefinitely an issue with the Mexican government, and however disagreeable and even false, my personal

${ }^{38}$ Buchanan to Slidell, March 12, I846; MS., Archives. 
position might have been, . . . no inconvenience to myself would have prevented me from performing my duty." " With the departure of Slidell the plan of acquiring California by peaceful means was shown to be a failure.

Slidell did not believe that the Paredes government would be able to maintain itself. The eyes of many Mexicans were turned to Cuba, where Santa Anna was living in exile. No one else could rally about him so much strength as the former popular idol. In the letter in which he reported the definite refusal of the Paredes government, Slidell wrote: "I shall not be surprised soon to hear of Santa Anna arrived at Vera Cruz and of a pronunciamento in his favor by the garrison there. If he have the nerve to take the step and get possession of Vera Cruz, he will easily put down Paredes. Should he arrive before my departure, I will ascertain his views in relation to the United States, and if I find them favorable, will not hurry my departure from Vera Cruz, but in the meanwhile, my expectation of amicable arrangements through Santa Anna ought not to delay the application which the President intends making Congress." 40 "Should Santa Anna be the successor of Paredes, the prospect would be better, but some time would be necessary to prepare his partisans for a step so unpopular as negotiation, and should he be disposed to take it, he would not scruple to make the preliminary overtures." "a

${ }^{30}$ Slidell to Buchanan, April 2, I846; MS., Archives.

${ }^{10}$ Slidell to Buchanan, March 15, I846 (received April I, "night") ; MS., Archives.

"Slidell to Buchanan, April 2, I846 (received April I6); MS., Archives. 
Santa Anna was the successor of Paredes. Polk was already in possession of Santa Anna's pretended views toward the United States. Events were now rapidly approaching war. The clash with Taylor at the Rio Grande was a fortunate circumstance for the administration. Before the news of Taylor's fight reached him Polk had determined to declare war upon Mexico. His statement that "war existed by the act of Mexico" was as inaccurate as the belief that war was the necessary consequence of the annexation of Texas. 


\section{CHAPTER XII}

The Outbreak of the Mexican War

It has been demonstrated, it is believed, that the Mexican War was not the result of the annexation of Texas. The Mexican War was waged for the purpose of conquest, for the fulfillment of Polk's designs upon California. War would have been declared against Mexico had the Mexicans not crossed the Rio Grande or come into conflict with Taylor. Again, Polk believed war with Mexico would be a small affair, scarcely ninety days in duration, to be terminated by a peaceful surrender of California, arranged by Santa Anna.

The first part of Polk's policy toward Mexico had been to acquire California by purchase. This attempt failed under Slidell. Herrera's successor, Paredes, refused to receive Slidell. Nothing was to be hoped for through diplomacy.

One day in February, after Polk had ordered Taylor forward to the Rio Grande and was awaiting the news of Slidell's final rejection, a visitor was admitted to the White House for a confidential conversation with the President. Polk, whose diary is usually terse in its comment upon men and things, deemed the communication of his visitor to be of sufficient importance to be entered in full in his book. Through this entry in the diary one is let more fully into the confidences of this close-mouthed and secretive President than were the members of his own cabinet. No less an authority than Bancroft has stated that Polk was the "master 
of his own cabinet and not ruled by the ablest of his advisers. One trait which gave him this controlling advantage was his power of secrecy, which was so great that those whose official intercourse was closest with him, were unable to trace the course of his thoughts." The diary has disclosed the secrets kept from the cabinet.

"Friday, Feby. I3-I846-Some company today until I2 o'clock," says the diary. "Among those who called was Col. Atacha, who called on me in June iast. He is a Spaniard by birth, but says he has become a naturalized citizen of the U. S. He has lived at New Orleans and spent many years in Mexico. He was with Santa Anna when his government was overthrown last year, was himself arrested but it being made known that he was a naturalized citizen of the U. S., he was ordered out of the country. He called on me in June last to present claims against the government of Mexico, with a view to have their payment urged by the Govt. of the U. S. Col. Atacha stated this A. M. he had visited Genl. Santa Anna in his exile at Havannah \& that he had left him a month ago-His conversation with me, he said, he desired to be confidential. He represented that Santa Anna was in constant communication with his friends in Mexico and received by every vessel that left Vera Cruz hundreds of letters. He intimated that the recent revolution in Mexico headed by Paredes met Santa Anna's sanction, \& that Santa Anna might soon be in power again in Mexico. He said that Santa Anna was in favor of a Treaty with the U. S. and that in adjusting the boundary between the two countries the Del Norte should be the western Texas line and the Colorado of 
the west, drawn through the bay of San Francisco to the sea, should be the Mexican line on the north \& that Mexico should cede all east and north of these natural boundaries to the U.S. for a pecuniary consideration, \& mentioned thirty millions of dollars as the sum. This sum, he said, Santa Anna believed would pay the most pressing debts of Mexico \& support the army until the condition of the finances could be improved \& enable the govt. to be placed on a permanent footing. Col. Atacha said that Santa Anna was surprised that the U. S. naval force had been withdrawn from Vera Cruz last fall, \& that Genl. Taylor's army was kept at Corpus Christi instead of being stationed on the Del Norte \& that the U. S. would never be able to treat with Mexico without the presence of an imposing force by land and sea, \& this Col. Atacha added was his own opinion. Col. Atacha did not say that he was sent by Santa Anna to hold this conversation with me. He said that he had told Santa Anna he had seen me in June \& that he would see me again, as soon as he reached Washington. Col. Atacha requested that this conversation should be considered as confidential." 1

At the cabinet meeting the next day Polk related the substance of Atecha's conversation. "Different members . . . expressed opinions concerning it. The idea of sending a confidential agent to confer with Santa Anna was mentioned. Mr. Walker was inclined to favor it \& Mr. Buchanan was decidedly opposed to it. I remarked that if such an agent were to be sent Gen. C. P. Van Ness, former minister to Spain, woinld

${ }^{1}$ Polk's Diary, February I3, I846. 
be the best selection in the country. I stated that I did not propose to send such a messenger but had merely suggested it, in view of the information given me . . . by Col. Atacha. The subject after a short conversation was dropped." " Santa Anna's emissary had made enough of an impression upon the President for Polk to cast about for a suitable person to meet Santa Anna. Atecha did not let the matter rest, but, once having the ear of the President, returned at the earliest opportunity for a further conference. The diary records: "He repeated that Gen. Santa Anna was in favor of a treaty between Mexico and the U. States, by which the former should for a pecuniary consideration cede to the U. States all the country east of the Del Norte and north of the Colorado of the West, \& had named thirty millions of dollars as a sum that would be satisfactory. I then remarked that Mexico must satisfy the claims of American citizens, \& that if the Government of Mexico had any proposition to make, such as was suggested, it would be considered when made, to which Col. Atacha said that no government in Mexico dared to make such a proposition, for if they did so, there would be another revolution by which they would be overthrown. He said they must appear to be forced to agree to such a proposition. He went on to give his own opinion and as he said that of Gen. Santa Anna that the U. States should take strong measures before any settlement could be effected. He said an army should be marched at once from Corpus Christi to the Del Norte \& a strong naval force assembled at Vera Cruz, that

'Ibid., February'14, 1846. 
our minister should withdraw from Jalapa \& go on board one of our ships at Vera Cruz \& in that position should demand the payment of amount due our citizens; that it was well known the Mexican Government was unable to pay in money \& that when they saw a strong naval force ready to strike on their coasts and border, they would, he had no doubt, feel their danger $\&$ agree to the boundary suggested. He said that Paredes, Almonte \& Genl. Santa Anna were all willing for such an arrangement, but that they dare not make it, until it was made apparent to the Archbishop of Mexico \& the people generally that it was necessary to save their country from war with the U. States. He said the last words which Genl. Santa Anna said to him, when he was leaving Havana, a month ago, was 'When you see the President, tell him to take strong measures, \& such a treaty can be made \& I will sustain it.' Col. Atacha said the Government of Mexico was indebted to the Archbishop half a million of dollars, \& he would be reconciled, by an assurance by the Mexican Government that he should be paid, when this consideration should be paid by the U. States. $\mathrm{He}$ said Paredes and Almonte were both in favor of such a settlement if they dare make it, and that Genl. Santa Anna concurring with them would support them in it. He said (Genl. Santa Anna) that the state of things would be in such a condition that he would return to Mexico in April or May, \& would probably go into power again, but that he \& Paredes must have money to sustain themselves. He said that with half a million in hand they could make the Treaty \& sustain themselves for a few months \& until the balance was paid. . . . $\mathrm{He}$ ( Col. A) intimated an 
intention to return to Havana \& as I inferred a desire to bear to Gen. S. A. the views of the Govt. here. To this intimation I gave no reply. My object in the conversation being to obtain information but not to disclose my own views. Col. A. is [a] person to who [m] I would not give my conficlence. He is evidently a man of talents and education but his whole manner of conversation impressed me with a belief that he would betray any confidence reposed in him when it was his interest to do so. I therefore heard all he said but communicated nothing to him.":

In all this there is no intimation that Polk considered it reprehensible to hold conferences with an agent of Santa Anna, an exile from Mexico, who was plotting to regain power and to that end desired the assistance of the United States. Atecha's proposition was that Polk should assist Santa Anna back into Mexico upon the understanding that the dismembermerit of Mexico would follow. Had Polk done nothing more than listen to Atecha's suggestions, these entries in the diary would not be of more than passing interest. The confidential communications, however, became the basis for Polk's actions.

In the cabinet at its next meeting Polk again referred to Atecha's communications. The President told the cabinet that new instructions should be given Slidell; that he should press for an immediate decision from Paredes as to his reception; and that in case he were definitely refused he should go upon one of the United States vessels of war off Vera Cruz and from it demand the immediate payment of the claims against

${ }^{3}$ Ibid., February 16, I846. 
Mexico. In case no answer was made to Slidell's demand, the President would send a message to Congress "calling on that body to cause another demand to be made by Mr. Slidell from on board a vessel of war on the Mexican Government to pay our demands and if this was refused by Mexico to confer authority on the Executive to take redress into our own hands by aggressive measures." "

Polk's plan did not have the unanimous approval of his cabinet. Buchanan, always timid, opposed it. Walker, Marcy, and Bancroft coincided with Polk. Johnson, the postmaster-general, inclined to side with Buchanan but was willing "to acquiesce." Polk notes that Buchanan was "in a bad mood," but finally, though not with good grace, agreed to prepare Slidell's new instructions as the President desired. ${ }^{5} \quad$ Under more recent information from Vera Cruz Polk delayed the letter to Slidell until March 12, when Slidell was ordered to get a final answer from Paredes as to his reception. A part of these instructions was printed under a call from the Senate. A part of them was omitted. In this suppressed part Slidell was told, before finally closing his mission, to sound Paredes on the subject of the financial necessities of his government. "It would be easy for you to make known to him in some discreet manner that the United States were both able and willing to relieve his administration from pecuniary embarrassment, if he would do us justice and settle the question of boundary between the two republics. A treaty for this purpose, under your instructions, if ratified by Mexico and trans-

"Ibid., February 17, 1846.

'Ibid., February 17, 1846. 
mitted to the United States, could be returned in a brief space with the ratification of the President and Senate. In the meantime Paredes could command immediately funds on such an assurance."

As has been seen, by the time Slidell received this communication he had left for the United States. No further overtures were made to Paredes. Polk had Santa Anna in his mind and based his hopes upon that exile's return to power.

From now on Polk proceeded to act upon his decision to call upon Congress to take aggressive action toward Mexico upon the assumption that Slidell's mission was a failure. He took certain members of the House and Senate into his confidence and asked them to support an appropriation of a million dollars to be placed in his hands "to be used in exacting an adjustment of our differences with Mexico." Calhoun was willing to grant all the money needed for obtaining the cession of Mexican territory, but he opposed an "appropriation in advance as it would become public and embarrass the Oregon negotiation." "From Slidell came finally (April 7) the news that Paredes would not receive him. Polk told the cabinet that he would make a communication to Congress asking "for legislative measures \& take the remedy into our own hands." With this idea all the cabinet agreed." The message Polk decided to delay until Slidell had returned to Washington, but he was so eager for action that, upon

- Buchanan to Slidell, March 12, 1846; partly printed in S. Ex. Doc. 337, 29 Cong., I Sess., 54. MS., Archives. Curtis's Buchanan, I., 596.

'Polk's Diary, March 30, I846.

${ }^{8}$ Ibid., April 7, 1846. 
Calhoun's remonstrance that nothing be done until the Oregon question was settled, he replied that he would proceed against Mexico during the present session of Congress whether the Oregon difficuity was settled or not. $\quad$ On the twenty-eighth of April the notice as to Oregon, passed by Congress, was signed. The cabinet decided that it was time to act toward Mexico. ${ }^{10}$ Soon afterwards Slidell arrived in Washington. He told Polk that "but one course towards Mexico was left to the United States, and that was to take the redress of the wrongs and injuries which we had so long borne from Mexico into our own hands and act with promptness and energy. In this I agreed with him and told him it was only a matter of time when I would make a communication to Congress upon that subject and that I had made up my mind to do so very soon."

On May 9 the cabinet agreed that if the Mexicans at Matamoros committed any act of hostility against Taylor war should follow, with a message to Congress. Polk said he had no new advices, but that we had ample cause for war; that things could not remain in statu quo nor would he remain silent much longer. He then stated that he expected to make his communication to Congress by the following Tuesday, May i2. He asked the cabinet if he should then declare war. All said yes except Bancroft, who stated that he would "feel better satisfied in his course if the Mexican forces had, or should, commit any act of hostility." Thus in a cabinet meeting, confessing that

'Ibid., April 18, 1846.

${ }^{10}$ Ibid., April 28, 1846.

${ }^{11}$ Ibid., May 8, 1846. 
no new advices had been received from Taylor, and acknowledging that the Mexicans had not committed any aggression against the American forces, Polk and his cabinet agreed to ask Congress to declare war against Mexico. Not only this, but the date was set for the delivery of the war message. ${ }^{12}$

By one of those strange happenings that result in the concealment of man's real motives, on the very - night following the meeting of the cabinet at which Polk had named a date for the sending of his war message came the news of the passage of the Rio Grande by the Mexicans and of the killing of Taylor's troops. The next day Polk spent in preparing his message. Circumstances now permitted this to be drafted in accordance with the wishes that Bancroft had expressed. That day was Sunday, May ıo. Polk's entry in his diary is as follows: "At IOI/2 o'clock I retired to rest. It was a day of great anxiety to me, and I regretted the necessity which had existed, to make it necessary for me to spend the Sabbath in the manner I have." 13

"War exists by the act of Mexico," Polk told Congress May I I, I846. Had the news from Taylor not been received when it was, Congress might have been informed that on account of the refusal of Paredes to receive Slidell, who had gone to make settlement of the claims of American citizens, the patience of the United States was exhausted; and that the honor and selfrespect of the United States could no longer permit Mexico to delay payment of righteous and long delayed claims. Whether Congress, which followed Polk in

${ }^{12}$ Ibid., May 9, I846.

${ }^{13}$ Ibid., May 10, 1846. 
declaring that war existed by the act of Mexico, would have sustained the President in a war that from the outset would admittedly have been one of aggression, it is impossible to state. Taylor's skirmish with the Mexicans was an occurrence that saved Polk from a dangerous situation.

In all this Polk did not lose sight of Santa Anna. The reports of Slidell, Conner, and finally of Atecha were not forgotten. Two days after the war message, Bancroft sent this order to Conner, commanding the naval forces before Vera Cruz. "Private and confidential. If Santa Anna endeavors to enter the Mexican ports, you will allow him to pass freely." Atecha had said that Santa Anna would attempt to return to Mexico in April or May. The date of Bancroft's order gives the impression that Polk believed Atecha's prediction would be verified. Polk was premature in this. Paredes was still in control of the government. A month later Polk sent Commander Alexander Slidell Mackenzie to Havana with a copy of Bancroft's order. What Mackenzie was ordered to do further than to get into communication with Santa Anna and to sound him as to his attitude cannot be ascertained from the records of the navy department. ${ }^{14}$

Among the Bancroft-Polk papers in the Lenox Library, New York, are copies of these reports made by Mackenzie to Buchanan. The following is the fullest

${ }^{14}$ MS., Records, Navy Department. Copy of Conner's order placed in Mackenzie's hand June 4, I846. Mackenzie to Bancroft, June (July) 7, I846 (received July 22), says he arrived at Havana June 5, and has attended to the matters for which he was instructed. Buchanan's overture for peace was daied July 27. Schouler, IV., 536; Benton, II., 68r. See also despatches of Consul Campbell at Havana. MS., Archives. 
and is included here in extenso because it is believed not to have been published hitherto. No apology is offered for the insertion of so long a document, for it is a necessary link in the chain of events in which Polk and Santa Anna played so important a part."

"Sir.

\section{"Havana 7 June 1846}

"I have the honour to state that I arrived here on the evening of the 5. July, and early on the 6. saw the U.S. Consul, and delivered to him your letter. Mr. Campbell readily and cordially complied with your request to assist me in the business with which I was charged. He immediately conducted me for the purpose of introduction to General Santa Anna's house. General Santa had given orders not to be disturbed. I left my card, writing on it that I bore a message from the President of the United States and would return at 8 P. M. I did so, and was courteously received, I had only read to him your letter to the Consul, stating that I possessed the confidence of the President, and the copy of the order which had been given by Commodore Connor to allow him to pass, and added a few words of the President's message, when he told me that he had visitors in the adjoining room, but would be glad to see me at 7 the following morning, when he would talk with more freedom.

"I waited upon him accordingly this morning and remained with him three hours. I began by reading to him a paper which I prepared on the evening of the

${ }^{15}$ These copies are dated June (July) 7 and July II, I846. Santa Anna in his autobiography says nothing about Mackenzie's visit. 
day on which I received the President's instructions, and subsequently submitted to Mr. Slidell who was present, to be verified by his recollections. The following is a copy of the paper thus translated to him:

" "The United States having taken up arms to resist the attack of the intrusive Military Government of General Paredes in Mexico, are determined to prosecute the war with vigour, until full redress is obtained for the wrongs which their citizens have received from Mexico through a long series of years.

" "Still the President of the United States is desirous, as he stated in his message to Congress, recommending the recognition of the existence of the war thus begun by Mexico not only to terminate hostilities speedily, but to bring all matters in dispute between his government and Mexico, to an early and amicable adjustment.

" "To attain this object the President would hail with pleasure the over-throw of the existing military despotism of General Paredes, which has sprung into power by cherishing hostility among his countrymen against the United States, and which has no hope for support but in the prolongation of the war; to be replaced by a government more in harmony with the wishes and true interests of the Mexican people, which cannot be allowed by a prolongation of the war; a government sufficiently enlightened and sufficiently strong to do justice to foreign nations and to Mexico herself.

" "Believing that General Santa Ana best unites the high qualifications necessary to establish such a government, and that as a well-wisher of his country he cannot desire the prolongation of a disastrous war, the 
President of the United States would see with pleasure his restoration to power in Mexico. In order to promote as far as he is able such a result, he has already given orders to the squadron blockading the Mexican ports, to allow General Santa freely to return to his country.

" 'The President of the United States will agree to no armistice with General Paredes, until he himself proposes to treat of peace, and gives satisfactory guarantees of his sincerity. With General Santa Ana, should he return to power in Mexico, the President would consent to the suspension of active hostilities by land, still maintaining the blockade of the mexican coasts, on either ocean, provided General Santa Ana announces his readiness to treat. In that event an American Minister, clothed with full powers, will be at hand to proceed at once to Mexico, and offer General Santa Ana terms for the settlement of every existing difficulty between the two countries.

" "These terms will be liberal; measured less by the power of the United States, by the comparative weakness of Mexico in existing circumstances, by the rights which conquest and the usage of nations might justify, than by a sense of their own magnanimity. As at present advised the President might demand no indemnification for the expenses of the war. Having obtained full recognition of the claims due for spoliations on his aggrieved countrymen-, he would be prompted to pay liberally for the establishment of such a permanent geographical boundary between the two countries as would effectually tend to the consolidation of both. 
" 'Portions of the northern territory of Mexico consist of unappropriated lands, or of tracts thinly peopled; partly peopled already by natives of the United States. These portions of her territory, probably at this moment in the military possession of the United States, Mexico in the adjustment of such a treaty will be invited to cede for an ample consideration in ready money, which will serve to restore her finances, consolidate her government and institutions, and building up her power and prosperity, tend to protect her against further encroachments, and secure her that station among the republics of the new world, which the President of the United States desires to see her occupy; and which he believes will alike contribute to the greatness and happiness of Mexico, and of the United States.

"Such objects being happily obtained, the animosities between the two countries being buried with the conflict in which they have been engaged, the President would hope to see a beneficial intercourse of friendship and commerce grow up between them, to be perpetually augmented with the lapse of years; and with no other rivalry between them-, than that of a noble competition in the cause of civilization, and in doing honor to their common name of Republics.'

"General Santa Ana received the message of the President with evident satisfaction, and expressed his thanks for the order that had been given with regard to the Gulf Squadron's permitting him to return to Mexico. He spoke with deep interest of his interview with General Jackson in Washington, and of the manner in which that venerable man had himself raised in the bed of sickness on which he was extended, to greet 
with cordiality a brother soldier in distress; and seemed duly to estimate the high and noble qualities which distinguished him. He spoke also of the kindness he had received from Mr. Forsyth and of the favorable impression that gentleman had made on him. He remarked that if he was disappointed in his hopes of returning to his country; if monarchy should be established there, or if it should remain a prey to anarchy, he intended to settle permanently in Texas, and becoming a citizen of the United States, share with his children the destinies of our country. He dwelt with apparent frankness on his regrets for the errors of his past administration of the affairs of his country, and on his intentions should he be again restored to power to govern in the interests of the masses, instead of parties, and classes. Among the measures of reform which he contemplated was reducing the wealth and power of the clergy, and the establishment of free trade. He showed me a letter which he had just received from an influential friend in the City of Mexico, urging his speedy return, and giving a lamentable picture of the conflict of parties in his unhappy country. In the course of our conversation as to the nature of the boundary we would require, he spoke of the Nueces, as having always been the boundary of Texas, and enumerated the various states, portions of which lay to the north of the Rio Bravo. I told him that neither the President nor the people of the United States would ever consent to any line north of the Rio Bravo, which was a large river, indicated by nature as a suitable boundary between two great states; that I was unacquainted with the precise views of the President, further than they might be in conformity with the general sentiment of the country, as to the 
extent of the cession Mexico would be required to make. That the popular sentiment would look for a line, which, starting from a given point on the Rio Bravo, would run due west to the Pacific along a parallel of latitude, so as at least to take in the port of San Francisco in California. That in general terms we should retain what would be deemed sufficient to give us a permanent boundary, from what we had already conquered; but that in doing so we would not avail ourselves, like other great nations, of the rights of conquest, but from a sense of magnanimity, and for our own satisfaction, as well as to conciliate the friendship of Mexico, we would pay liberally for whatever we might retain. In reply to an enquiry I made of him, he informed me that no commissions for privateers had been issued by the Mexican Government, of whose movements his correspondence kept him fuliy informed. Such a measure of annoyance had been considered by the existing government, but it had been deemed impracticable.

"Subsequently to or during the continuance of this conversation in part, he drew up the following note of what he desired to communicate in reply to the President. This I copied at his request and read over to him to see that it corresponded word for word with the original, which he then destroyed.

"Senor Santa Ana says: that he deplores the situation of his country: that being in power, he would not hesitate to make concessions rather than to see Mexico ruled by a foreign prince, which the monarchists are endeavoring to introduce ('Elevar,' rather 'raise up') ; that being restored his country, he would enter into negotiations to arrange a peace by means of a treaty of limits; that he especially prefers a friendly 
arrangement to the ravages of war which must be calamitous for his country: that although the republicans of Mexico labour to recall him and place him at the head of the government, they are opposed by the monarchists, headed by Paredes and Bravo: That he desires that republican principles should triumph in Mexico, and that an entirely liberal constitution should be established there; and this is now his programe: That if the government of the United States shall promote his patriotic desires, he offers to respond with such a peace as has been described. He desires that the mediation of England and France may not be aocepted; and that every effort should be directed towards promoting his return to power in Mexico, by protecting the Republican party. To attain this object he considers it necessary that General Taylor's army should advance to the city of Saltillo, which is a good military position, ${ }^{16}$ compelling General Paredes to fight as he considers his overthrow easy: ${ }^{17}$ and this being effected General Taylor may advance to San Louis Potosi, which movement will compell Mexicans of all parties to recall Santa Ana.

16 "On asking him at this point if Monterey was a good Military position he said it was not." (Mackenzie's note.)

${ }^{17}$ "He remarked to me at this point: 'Que Taylor le festija bien!' literally, 'let Taylor feast or entertain him well'meaning 'follow him up,' 'keep him going.' He added that Paredes was not brave. I told him that the opinion concerning Paredes in the U. S. was that he was weak-minded and wrong headed, but impetuous and brave. He said that in a battle which he named, but which I have forgotten, Paredes being his aid-de-camp hid himself in a thicket, from which he had drawn him with reproaches. I know not how far allowance should be made for personal hatred in receiving this statement, though the words were given, and the scene described with particularity." (Mackenzie's note.) 
" 'General Santa Ana also desires that the greatest secrecy be observed concerning these communications, and that they be only communicated by the bearer as far as may be necessary, since his countrymen not appreciating his benevolent intentions to free them from war and other evils might form a doubtful opinion of his patriotism. That all the American cruisers should be directed under the strictest injunctions of secrecy not to impede his return to Mexico. He likewise enjoins that the people of the towns occupied by the American army should not be maltreated, lest their hatred should be excited. ${ }^{18} \mathrm{He}$ considers it important to attack Ulloa, and judges that it would be best first to take the city, whose walls are not strong: the disembarkation of three or four thousand men would effect it easily. ${ }^{10} \mathrm{He}$ considers important the occupation of Tampico, and wonders that it has not been effected, since it might be so easily done. The climate is healthy in October and continues so until March. Finally he desires that his good repute may be protected by the newspapers of the United States, and that they represent him as the Mexican who best understands the interests of his country, and as the republican who will never compromise with the monarchists, nor ever be in favor of foreign and European intervention. He says that it will be well not to blockade the ports of Yuchatan, as he counts upon that

18 "I told him that it might be in harmony with our political sentiments to protect the republican party, but opposed to our national character to oppress any one. I told him what had been and would continue to be, the conduct of our army." (Mackenzie's note.)

10 "At my request he named October as the proper month for this service, and the beach, without cannon-shot, as the proper place of disembarkation." (Mackenzie's note.) 
state, being in communication with its authorities; and perhaps he will transfer himself to that point, if clrcumstances prove favourable.'

"The military suggestions contained in General Santa Ana's note seemed to me of so much importance that in order to save time, so valuable in war, I suggested to him the propriety of their being at once communicated to General Taylor, to be used by him, if he should deem them important, within the limits of his orders and discretionary power. He asked if General Taylor was reserved and incommunicative. I replied that all I knew of him was in common with the public, from his recent acts, and the written reports in which he had made them known to the government, which proved him not only to possess the highest qualities of a commander, but to be a man of prudence, moderation and reserve. He admitted that his reports strongly conveyed this impression, and thought favourably of my proposition to proceed at once to the head quarters of our army. This though not contemplated by my instructions $I$ have determined to do.

"If I have made a mistake and exaggerated the importance of this information, I hope that an excuse may be found in my motive, which was by any means in my power to render service to my country.

"I have the honor to be very respectfully,

"your most obedient "Alex. Slidell Mackenzie.

"Hon. James Buchanan

"Secretary of State, "Washington." 20

20 "Rec'd Aug. 3." 
Early in August Santa Anna passed the American blockade and landed at Vera Cruz. That city received him as a hero, and he proceeded to the capital as the savior of the nation. By the middle of August he was in command of the Mexican forces and president ad interim of the Mexican Republic. Hardly had he arrived at the City of Mexico when Buchanan's note was submitted to him, suggesting that peace negotiations be forthwith begun. ${ }^{21}$ The offer was declined. ${ }^{22}$ Santa Anna as a military chieftain was not Santa Anna in exile. Buchanan's answer to the refusal was that henceforth the war would be prosecuted with vigor until Mexico offered to make terms. ${ }^{23}$

${ }^{21}$ Buchanan to the Mexican Minister of Foreign Affairs, July 27, I846; Cong. Globe, Appendix, 29 Cong., 2 Sess., 24.

${ }^{22}$ The Mexican Minister of Foreign Affairs to Buchanan, August 31, 1846, ibid.

${ }^{23}$ Buchanan to the Mexican Minister of Foreign Affairs, September 26, 1846; ibid. 


\section{CHAPTER XIII}

The Treaty of Guadalupe Hidalgo, 1848

From September, I846, when Mexico was notified that hostilities would not be interrupted until she offered to make peace, the war was waged in earnest. It appeared no longer to be a little war. Scott took command of the army, and the storm-center shifted from the northern provinces to Vera Cruz. And yet Mexico gave no sign of a desire for peace. Polk therefore was again compelled to make overtures for settlement, and this time by offering a specific proposition. In January Buchanan wrote to the Mexican minister of foreign affairs that although making "a renewed overture for peace" might "be regarded by the world as too great a concession to Mexico, yet he" was "willing to subject himself to this reproach." If Mexico so agreed he would send commissioners either to Havana or Jalapa clothed with full powers to conclude a treaty of peace and given authority to suspend hostilities and raise blockades as soon as the Mexican commissioners met them. ${ }^{1}$ The Mexican answer was in spirit like its predecessors: Mexico would appoint commissioners as suggested, but not until the blockades were raised and all the territory of the Mexican Republic was evacuated by the invading army. ${ }^{2}$ Such an answer was tantamount to a refusal, and so Polk considered it. When, in the middle of April, news of the

${ }^{1}$ Buchanan to the Mexican Minister of Foreign Affairs, January I8. I847: S. Ex. Doc. I, 30 Cong., I Sess., 36.

"Monasterio' to Buchanan, February 22, 18.17; ibid., 37. 
fall of Vera Cruz reached Washington, it was thought that Santa Anna could no longer refuse to negotiate, for the American arms were everywhere victorious, and Scott's army was on the march toward the capital.

Now was the time, in Polk's strange phrase, to "conquer a peace." Buchanan informed Mexico that the offer to negotiate would not be renewed (strong language until the context is heard) until the President had reason to believe that it would be accepted by the Mexican government. "The President .

devoted . . . to honorable peace," so wrote Buchanan to the Mexican minister of foreign affairs, "is determined that the evils of the war shall not be protracted one day longer than shall be rendered absolutely necessary by the Mexican republic. For the purpose of carrying this determination into effect with the least possible delay, he will forthwith send to the head-quarters of the army in Mexico, Nicholas P. Trist, esq., the officer next in rank to the undersigned in our department of foreign affairs, as a commissioner, invested with full powers to conclude a definite treaty of peace with the United Mexican States." Thus did Polk act upon a plan for negotiation by an agent not confirmed by the Senate, a method quite without precedent or parallel. The appointment of public commissioners might only subject the United States to the indignity of another refusal and give the Mexicans encouragement in their opinion concerning the President's motives for desiring the termination of the war. Influenced by these considerations, he hit upon the

${ }^{3}$ Buchanan to the Mexican Minister of Foreign Affairs, April 15, 1847; ibid., 38-39. Also in Raphael Semmes, Service Afloat and Ashore during the Mexican War, 303-6. 
plan of sending "to the head-quarters of the army a confidential agent, fully acquainted with the views of this government, and clothed with full powers to conclude a treaty of peace with the Mexican government, should it be so inclined." He would be enabled in that case "to take advantage, at the propitious moment, of any favorable circumstances which might dispose that government to peace." " In the selection of this agent the President again proceeded upon altogether unusual lines. General Scott is authority for the statement that Polk wanted Silas Wright to undertake the mission, intimating that Scott would be Wright's associate. $^{5} \quad$ This was surely a strange selection, for Wright was a well-known advocate of the Wilmot Proviso, and Scott was personally obnoxious to the President. "Scott," said Polk, "is utterly unqualified for such a business." " No man of national prominence could be expected to assume the role of a confidential agent to accompany the army and jump at a propitious moment to conclude a treaty. The chief clerk of Buchanan's department, personally little known to the President, was selected for the mission, a man with but meager training in diplomatic affairs, anything but robust in health, irritable, suspicious, and timid, and, moreover, given to great verbosity of statement.

Nicholas Philip Trist was a Virginian by birth and was for a time a cadet at West Point. He did not graduate, however, but began the study of law under Jefferson, whose granddaughter he had married. At

- Buchanan to Trist, April 15, 1847 ; S. Ex. Doc. 52, 30 Cong., I Sess., 81.

${ }^{5}$ Scott's Autobiography, II., 576.

'Polk's Diary, July I5, 1847. 
twenty-eight he was a clerk in the treasury department when Jackson selected him as his private secretary. After a short service in that capacity he was consul at Havana for eight years, whence he was recalled on the ground that he had aided the slave-trade. Soon after the beginning of Polk's administration he was made chief clerk of the state department, and during his service there he appeared as a hard-working administrative officer in the departiment presided over by the somewhat timid Buchanan and really directed by the energetic Polk. The chief clerk gave evidence of uncompromising loyalty to the President and thorough sympathy with his plans. His selection for this delicate mission was probably due not so much to Polk's overestimation of Trist's diplomatic abilities as to an underestimate of the difficulties of the undertaking. It had appeared a simple thing to send Slidell to Mexico as the representative of a strong power to strike a bargain, through claims and a bonus, for the cession of New Mexico and California-how could so "feeble and distracted a nation as Mexico" refuse a liberal cash offer? The answer to that question had been war. Now that Congress had placed three millions of dollars in Polk's hands for the "speedy and honorable conclusion of the war," the President seemed to think that to negotiate a peace treaty upon terms dictated by himself was a mere clerical act for an agent accompanying a victorious army.

${ }^{7}$ Trist was commissioned consul at Havana April 24, I833. Tyler ordered his recall June 22, I84I. There is a mass of correspondence connecting Trist with aiding the slave-trade attached to a complaint from Fox to Forsyth, February i2, I840; MS., Notes from British Legation to the Department of State. 
Whatever may have been the oral instructions that Trist received from the President, the official letter from Buchanan gave him small discretionary powers. Trist was handed a projet of a treaty, and with it the statement that the extension of the boundaries of the United States over New Mexico and Upper California was to be considered a sine qua non of any treaty. What Buchanan had authorized Slidell to do before the war began was now, thanks to the victorious advance of the army, made an ultimatum. Trist was authorized to pay in addition to the claims not more than twenty millions for the cession of New Mexico and Upper California, and not more than five millions additional for Lower California, while the right of transit and passage over Tehuantepec was held to be worth another five millions, the consideration to be paid in annual instahnents of three millions each. In any event the southwestern boundary was, of course, to be the Rio Grande. What Slidell had been authorized to offer twenty-five millions for, Trist was instructed to secure for twenty. The provisions as to Lower California and the right of transit over Tehuantepec were new, no mention of them having been made when Slidell was sent upon his mission. The projet accompanying Trist's instructions contained eleven articles covering the points just referred to. The third article provided that as soon as the treaty was ratified by Mexico the military and naval commanders of both sides should be informed of the action as quickly as possible, after which an immediate suspension of hostilities should take place. Such was the expression of Polk's idea of "conquering a peace." Pending the negotiations of peace the United States was not to bind itself to 
discontinue offensive operations against Mexico; hostilities were not to cease until Mexico had actually ratified the peace treaty upon our own terms. ${ }^{8}$

The confidential agent and commissioner left the capital for Mexico, and soon Buchanan began to receive Trist's long and tediously circumstantial communications. From New Orleans he wrote a dozen pages minutely describing his trip and the dangers of the journey from Mobile thither. Arrived at Vera Cruz, May 6, he quickly despatched two more reports, filled with his views upon the officers of the army and things in general. Illness seems to have held him for a while, as his next letter is from Jalapa, dated two weeks later. By this time he was involved in a hightempered and wordy epistolary quarrel with the commanding general. Trist had been directed by $\mathrm{Bu}-$ chanan to communicate his instructions in confidence to Scott and to deliver to him Buchanan's letter for transmission to the Mexican minister of foreign affairs. Instead of waiving formalities and putting himself on friendly and confidential terms with Scott, Trist immediately on his arrival at Vera Cruz sent the American commander a note inclosing the letter from Buchanan, sealed, and with it orders from Marcy. Scott was ever suspicious of the administration at Washington, and now he opened the vials of his wrath upon the commissioner. He was ordered by the secretary of war to yield to Trist the right to decide upon the suspension of military operations. It is doubtful if a more astounding order was ever sent to a commanding officer in the field, and Scott replied to Trist that the secretary of

${ }^{8}$ Buchanan's projet, S. Ex. Doc. 52, 30 Cong., I Sess., 85-89. 
war proposed to degrade him by requiring that he, as commander of the army, should defer to the chief clerk of the department of state the question of continuing or discontinuing hostilities." Consequently Scott returned the sealed letter from the department of state and, as a purely military question, declined to obey the order of the secretary of war, unless Trist was clothed with military rank over him. The next month was spent by the commissioner in writing voluminous letters to Scott, which the latter answered in kind. Trist lectured the general upon his lack of respect for the commissioner sent by the President. Scott replied that Trist's letter was such a farrago of insolence, conceit, and arrogance as to be a choice specimen of diplomatic literature and manners. "The Jacobin convention of France never sent to one of its armies in the field a more amiable and accomplished instrument. If you were armed with an ambulatory guillotine, you would be the personification of Danton, Marat, and St. Just, all in one." 10 On June 4 Scott wrote to Marcy, asking to be recalled, owing to the many "cruel disappointments and mortifications" he had "been made to feel since" leaving "Washington, and the total want of support and sympathy on the part of the War Department." ${ }_{11}$ The administration responded with orders to each to cease the disgraceful quarrel and to join in carrying out the plans of the government. ${ }^{12}$

Much of this quarrel doubtless had its origin in

- Scott to Trist, May 7, 1847; ibid., 157-59.

${ }^{10}$ Scott to Trist, May 29, 1847; ibid., 172.

${ }^{11}$ Scott to Marcy, June 4, 1847; ibid., 129-31.

${ }^{12}$ Marcy to Scott, July 12, 1847; ibid., 131. Buchanan to Trist, July I3, I847; ibid., II3. 
politics. The military history of the Mexican War is largely made up of jealousy and its consequent wrangles, which, ending in arrests and courts-martial, were transferred from the field of operations to Washington. "The truth is," Polk wrote in his diary, June I2, "I have been compelled from the beginning to conduct the war against Mexico through the agency of two generals, highest in rank, who have not only no sympathies with the government, but are hostile to my administration. Both of them have assumed to control the government. To this I will not submit and will as certainly remove General Scott from the chief command as he shall refuse or delay to obey the order borne him by Mr. Trist." ${ }^{13}$ For some time, however, as their despatches show, Trist and Scott continued their unseemly altercation. "Between them," the diary says, "the orders of the Secretary of War and the Secretary of State have been disregarded and the danger has become imminent that the golden moment for concluding a peace with Mexico may have passed." ${ }^{14}$ The President was for recalling both Scott and Trist, but the cabinet was unanimous in the opinion that it would be bad policy to do so. Realizing Trist's inefficiency, Polk then suggested that Soule or Jefferson Davis be associated with him, but nothing came of the suggestion. ${ }^{15}$

Writing from Puebla, June I3, Trist stated that he had had no intercourse with Scott for a month, although he had been near him for more than that time. ${ }^{16}$

${ }^{13}$ Polk's Diary, June I2, I847.

${ }^{14}$ Ibid.

${ }^{15}$ Ibid., July 9, 1847.

${ }^{16}$ Trist to Buchanan, June 13,1847 ; S. Ex. Doc. 52, 30 Cong., I Scss., I78-8I. 
His next letter, dated July 7 , in which he is supposed to have given his reasons for making peace with the general, was never received at Washington. Scott made no report to the secretary of war from June 4 to July 25. At that time each asked that the correspondence relating to the quarrel be suppressed. ${ }^{17}$ What caused the reconciliation, as far as their letters show, must remain a mystery. During the time in which Trist and Scott were quarreling, Trist asked the British minister, Bankhead, and Thornton, the British secretary of legation, to transmit to the Mexican authorities Buchanan's letter, which Scott had refused to receive. Bankhead and Thornton readily acquiesced in his request and forwarded the letter to Ibarra, the acting minister of foreign affairs. In a few days the commissioner received through the same channel of communication the answer of the Mexican government. It was that the determination of the question of peace must rest with the Mexican congress. ${ }^{13}$

So far there was no reason to believe the way open for negotiations. Santa Anna sent a message to the congress in which he peremptorily ordered it to state whether or not any propositions for peace should be listened to. ${ }^{18}$ When the Mexican congress scattered and made no answer to the message, Santa Anna informed Mackintosh, the British consul at the City of

${ }^{17}$ Scott to Marcy, July 25, 1847: "Since about the 26th ultimo, our intercourse has been frequent and cordial; and I have found him [Trist] able, discreet, courteous, and amiable." Ibid., 135. Trist to Buchanan, July 23, I847: Scott's "character I now believe that I had entirely misconceived." Ibid., 302.

${ }^{18}$ Ibarra to Trist, June 22, I847; MS., Archives.

19 Santa Anna to the Mexican Congress, July I6, I847; $S$. Ex. Doc. 52, 30 Cong., I Sess., 302-5. 
Mexico, that as he was abandoned by the congress, he must, as military chief, endeavor to make peace. ${ }^{20}$ His secret agents then intimated to Trist that while nothing could be done without the use of money, yet if a million dollars were placed in his hands at the conclusion of the peace and ten thousand immediately, commissioners would be sent to meet the American commissioner and negotiations begun. ${ }^{21}$ It was at this juncture that Scott and Trist began to be upon the most friendly terms, and Trist was a welcome guest at Scott's headquarters. Trist reported to Buchanan, upon the authority of Thornton, that Santa Anna would let Scott advance close to the City of Mexico and then negotiate. ${ }^{22}$ What was not reported was that Scott paid the ten thousand dollars of earnest-money after consultation with his officers. ${ }^{23}$ The matter did not come to Polk's attention until December, when General Pillow, enraged at what Polk called Scott's persecution of that officer, wrote of it to the President. ${ }^{24}$ Scott reported the expenditures

${ }^{20}$ Thornton to Trist, July 29, I847; MS., copy, Bureau of Indexes and Archives, Department of State.

${ }^{21}$ Ripley's War with Mexico, II., I48-70. Polk's Diary, December I8, I847.

${ }^{22}$ Trist to Buchanan, July 23, I847; MS., Bureau of Indexes and Archives, Department of State.

${ }^{23}$ Ripley's War with Mexico, II., I48-70. General Shields, however, told Polk that Trist was not present at the conference. Polk's Diary, December 28, 1847 .

${ }^{24}$ Polk's Diary, February 16, 1848: "The chief clerk of the War Department brought to me today a letter received from Majr. Genl. Pillow, dated at the City of Mexico on the 18th. of January in answer to a letter of the Secretary of War addressed to him in relation to certain proceedings of General Scott and Mr. Trist at Puebla in July last concerning an attempt to use money without any authority or sanction of the government, to bribe the authorities in Mexico, to secure 
as those for secret service and asserted that he had never tempted the honor or patriotism of any man, but held it as lawful in morals as in war to purchase valuable information or services voluntarily tendered him. "General Scott's answer is evasive," is the entry in the diary, "and leaves the irresistible inference that such a transaction took place and that it will not bear the light." ${ }^{26}$ Writing to Buchanan, July 23, Trist copied a letter received by him from an unnamed source. 'Trist's correspondent, in whom undoubtedly the commissioner placed great confidence, wrote: "Santa Anna is afraid to make peace now and cannot. $\mathrm{M}-{ }^{27}$ can do nothing with him, even with the aid he possesses from you. S. A. now says secretly that he shall allow your army to approach this city [Mexico], even as far as the Peñon, and then endeavour to make peace." ${ }^{28}$ The advance of the army, however, was by no means unobstructed. The decisive victory at Contreras, followed by that at Churubusco, opened the way to the capital. Instead of pushing on to clinch the former victories, as the

peace. This letter discloses some astounding facts in relation to that infamous transaction and must lead to a further investigation." In the letters-received book of the war department is the following entry under date of March $3 \mathrm{I}$, I848: "Pillow, Maj. Genl. G. J., Mexico, Jany. 18, I848. In answer to letter of Sec. War, Dec. 24, I847, and relates to negotiations carried on at Puebla in July and Aug. 47." The letter referred to cannot be found in the war department. See Tyler's Tylers, III., I72.

${ }^{25}$ Scott to Marcy, February 6, I848; H. Ex. Doc. 60, 30 Cong., I Sess., 1085. There is some discrepancy in the date.

${ }^{26}$ Polk's Diary, February 19, 1848.

${ }^{27}$ Mackintosh?

${ }^{28}$ Trist to Buchanan, July 23, I847, P. S., July 25; MS., Bureau of Indexes and Archives, Despatches, Mexico, Vol. I4. 
rules of military science would seem to have dictated, Scott halted his army and proposed an armistice. Was this done, as Scott said, lest the elements of peace might be scattered, or was it with the expectation that Santa Anna, with a part of the consideration cash in hand, would carry out the balance of the bargain? Through the good offices of Thornton, who with Bankhead and Mackintosh played a large part in all these negotiations, the armistice became effective August 24 . Santa Anna appointed as commissioners four wellknown peace men to meet the American commissioner.

The opportunity for which Trist had been waiting since May was now presented. Santa Anna's commissioners met him as agreed. No further evidence of Trist's utter incapacity is needed than his own account of the conferences. Two days before the first meeting he made known to Santa Anna that in order to secure the boundary defined in his projet, with the right of transit over the isthmus, he was authorized and willing to go as high as the highest sum named in his instructions. This amount, he said, might be paid in such a way as to enable Santa Anna to convert all of it into cash as soon as the treaty was ratified..$^{20}$ Such an unfortunate admission had the result he might have expected. Santa Anna's commissioners submitted a counter-projet conceding nothing but Upper California north of the thirty-seventh parallel, for which the United States was expected to assume the claims and pay a bonus. ${ }^{30}$ The Mexican commissioners insisted on the Nueces as a boundary, declaring that if

${ }^{29}$ Trist to Buchanan, September 4, I847; MS., Bureau of Indexes and Archives, Department of State.

${ }^{30}$ S. Ex. Doc. 52, 30 Cong., I Sess., 339. 
peace were made the line must be at that river. Trist hesitated and then offered to refer the question to Washington, thereby proposing to extend the armistice for at least forty-five days. ${ }^{31}$ No more flagrant disobedience of orders was ever committed. The war had been begun and waged upon the theory that the Rio Grande was the ancient boundary of Texas. What persuaded Trist to submit the matter for further instructions is incomprehensible. He himself explained it by saying that the Mexican commissioners led him to believe that a part of New Mexico would be ceded if the Nueces were accepted as a boundary. There was no reasonable foundation in fact, however, for any such belief, for Mexico demanded Trist's decision within three days upon the counter-projet, by the terms of which New Mexico was to remain a Mexican province. Before that short time had elapsed Santa Anna's violations of the armistice became so notorious that Scott gave notice of its termination. The American army moved toward the capital and entered it only after two of the bloodiest battles of the war. Santa Anna's army was scattered and without a leader. Notwithstanding all this, Trist was blind to Santa Anna's duplicity. As late as September 27 he wrote that he was perfectly convinced of Santa Anna's sincere desire for peace, but that peace was an impossibility upon the terms of Buchanan's instructions. ${ }^{82}$ The armistice was a strategic blunder, giving Santa Anna opportunity to mass his forces for the defense of the capital, and the heavy losses suffered by Scott's army at Molino

31 The Mexican Commissioners to the Minister of Foreign Relations, September 7, I847; ibid., 344-46.

${ }^{82}$ Trist to Buchanan, September 27, 1847; ibid., 201. 
del Rey were the price paid for it. The overtures for peace displayed the gullibility of Trist, whose persistent belief that Santa Anna once bought would stay bought led him to ignore his instructions and to disobey Polk's most positive orders.

Before Trist's reports of his inglorious conferences reached Washington, Polk had read the Mexican accounts of the affair sent from Vera Cruz. The President at once ordered Trist's recall. "Mr. Trist is recalled," says the diary, "because his remaining longer with the army could not probably accomplish the objects of his mission, and because his remaining longer might and probably would impress the Mexican government with the belief that the United States are so anxious for peace, that they would ultimate[ly] conclude one upon Mexican terms. Mexico must now sue for peace and when she does, we will hear her proposition." ${ }^{33}$ Trist's actions had surely merited his recall, but Polk's policy of continually making overtures, first by a series of notes suggesting peace and finally by sending a commissioner, gave Mexico exactly the belief that Polk attributed to Trist's blundering efforts alone. The policy was ill-advised and its instrument incompetent.

The occupation of the City of Mexico, September I4, completely changed the complexion of affairs. Two days later Santa Anna resigned the presidency, and by so doing removed the one great obstacle to peace. Within a week after Santa Anna's abdication plans were well under way for the reorganization of the government under the auspices of well-knowil

${ }^{33}$ Polk's Diary, October 5, 1847. Trist's despatch of September 4 was received October $2 \mathrm{I}$. 
moderados. Before it had been accomplished Trist again asked the Mexican commissioners to meet him. A month elapsed before he had an answer, and he asked Buchanan for permission to return home, as the weakness of the new government might keep him "hanging here for an indefinite period" without accomplishing anything. ${ }^{34}$ Buchanan's letter of recall reached Trist November 16. Trist acknowledged it, waived for the moment any defense of his actions, and stated that he would start home at once. Following hard upon the receipt of his recall Trist received word, again through Thornton, that the new Mexican administration had appointed commissioners. ${ }^{35} \mathrm{He}$ replied, November 24 , that, as he was about to return to the United States, whatever overtures Mexico desired to make would be forwarded through Scott to Washington. ${ }^{36}$ Despite this statement and notwithstanding his orders to return, he began immediately to negotiate with the Mexican commissioners upon the basis of his original instructions. The reasons for this change in plans are set forth in a letter of sixty pages written December $6 .^{37}$ This letter was certainly of a character to arouse the President's indignation. The diary describes it as "impudent, arrogant, very insulting to the government and personally offensive to the President." The writer of it was "destitute of honor or principle and contemptibly base." "It is manifest to me," wrote

${ }^{34}$ Trist to Buchanan, October 31,1847 ; S. Ex. Doc. 52, 30 Cong., I Sess., 213.

${ }^{35}$ Thornton to Trist, November 22, 1847 , and to Peña y Peña, November 24, I847; ibid., 231.

${ }^{36}$ Trist to Peña y Peña, November 24,$1847 ;$ ibid.

${ }^{37}$ Trist to Buchanan, December 6, I847 (received January I5, I848); ibid., 23І-66. 
Polk, "that he has become the tool of General Scott and his menial instrument and that the paper was written at Scott's instance and direction. I directed the Secretary of War to write to Major General But-。 ler [who had superseded Scott], directing him, if Mr. Trist was still with the headquarters of the army, to order him off and to inform the authorities of Mexico that he had no authority to treat." ${ }^{38}$ Scott, writing at the same time, said: "No proposition has been made to me, looking to a peace, by the federal government of this republic, or its commissioners; the latter understood to be still in this city. I have not seen them." ${ }^{39}$

This long despatch of Trist's doubtless justified Polk's suspicion that Scott instigated it. While Trist said that the government would be left at liberty to disavow his act, he set forth his reasons for reopening negotiations as: (I) that peace was still the desire of the President; (2) that unless he seized the opportunity offered, no other chance for peace would remain; (3) that the boundaries stipulated in his instructions were as much as Mexico would ever yield; and (4) that his recall was based upon a supposed state of facts the reverse of the truth. Underlying all of his arguments in support of these reasons is the thinly disguised innuendo that the President had changed his plans and now favored the annexation of all Mexico. In other words, Trist proceeded to make a treaty embodying Polk's original idea of territorial indemnity with the express intention of throwing upon the President the unpleasant alternative of either ac-

${ }^{38}$ Polk's Diary, January I5, I848.

${ }^{39}$ Scott to Marcy, December 4, 1847; H. Ex. Doc. 60, 30 Cong., I Sess., I033-35. 
cepting the treaty or rejecting it. If Polk rejected it, he must bear the odium of seeking to annihilate Mexico as a nation and of renewing a war which was now unpopular. If he accepted it, he would then, according to Trist's belief, sacrifice his clierished wish, the conquest of the whole of Mexico. Such is the import of this unique despatcil. Trist's assumption that Polk desired the absorption of all Mexico has been proved to be baseless. ${ }^{40}$ Reasonably enough, the President felt that the amount of money to be paid Mexico for the cession should be less than would have been the case had the war ceased seven months before. Pillow was in favor of greater territorial indemnity and claimed while in Mexico to be the President's mouthpiece. Trist shared Scott's hatred of that officer, and the parts of the despatch not directly or by inference attacking Polk are filled with venom against Pillow.

Before Butler had an opportunity to carry out Polk's order, Trist had signed the treaty and sent it on its way to Washington. There are no detailed accounts of the conferences of which the treaty was the result. We know that for two months Trist met the commissioners daily, that the original projet was taken as a basis for the negotiation, and that there was apparently little difficulty in agreeing upon boundaries. The question of claims and of the condition of the inhabitants of the ceded territory occupied most of the meetings. The result was in hand February 2, I848, when Trist met the Mexican commissioners to sign the treaty at Guadalupe Hidalgo, "a spot," said Trist, "which,

40 "The United States and Mexico, 1847-1848," by Professor E. G. Bourne, in American Historical Reviezv, V., 49I-502, April, I900. 
agreeably to the creed of this country, is the most sacred on earth, as being the scene of the miraculous appearance of the Virgin, for the purpose of declaring that Mexico was taken under her special protection." ${ }^{41}$

Seventeen days later Polk had in his hands the grant of territory that he had hoped to obtain through the peaceful negotiations of Slidell. The Rio Grande was acknowledged as the boundary of Texas; New Mexico and Upper California were ours; and the sum to be paid was that named in 'Trist's projet: the treaty included all of Polk's sine qua non. That the right of transit over Tehuantepec was not included was a small matter, for the recent treaty with New Granada afforded a better route to the Pacific. Benton's comment upon the treaty was that it was a fortunate event for the United States and especially for Polk's administration. "The Congress elections were going against the administration, and the aspirants for the presidency in the cabinet were struck with terror at the view of the great military reputations which were growing up." ${ }_{42}$

Haste in acting upon the treaty was of the utmost importance for two reasons: first, that the treaty might be returned to Mexico for ratification before the Mexican government should be overthrown; and second, that the growing sentiment for "all of Mexico," both in the cabinet and out of it, a sentiment to which the President was opposed, might be effectually stifled. ${ }^{43}$

${ }^{11}$ Trist to Buchanan, February 2, 1848; S. Ex. Doc. 52, 30 Cong., I Sess., I02.

"Benton's Thirty Years' View, II., 710.

${ }^{43}$ Professor Bourne's article as cited. The rreaty arrived in Washington February 19; Polk decided to send it to the Senate for ratification February 21. Polk's Diary, February 
Polk made up his mind at once not to reject the treaty because of Trist's conduct. His desire for peace was so great that he did not permit himself to be influenced by his indignation at Trist's insulting letters. He decided, after stating his views to the cabinet, to send the document to the Senate, suggesting certain amendments, and by so doing to show a "magnanimous forbearance toward Mexico." Every member of the Senate conmittee on foreign relations, with the exception of the chairman, Sevier, was at first opposed to ratification. The reason for their attitude, as reported by the chairman to Polk, was not the terms of the treaty, but Trist's lack of authority to negotiate. "I told Sevier," the diary records, "that the treaty was the subject for consideration, not Trist's conduct and that if the provisions of the treaty were such as would be accepted, it would be worse than an idle ceremony to send out a grand commission to re-negotiate the same treaty." "t The Senate committee reported the treaty without amendment on the same day, and after two weeks' discussion the Senate first amencied and then ratified it by a vote of thirty-eight to fourteen. The most important of the amendments was made at the suggestion of the President, and by it the tenth article, relating to the disposition of the public lands in Texas, was stricken out. An additional secret article, delaying for

21, I848. Calhoun wrote to Clemson, March 7, 1848: "The greatest danger is that the [Mexican] Government may not hold together until the treaty is exchanged. Nothing but the countenance of our Government and the support of capitalists interested in preserving it, can continue it in existence. It is, indeed, but the shadow of a Government." Report of American Historical Association, I899, II., 746.

${ }^{44}$ Polk's Diary, February 28, I848. 
eight months the time of Mexico's ratification, was for obvious reasons omitted by a unanimous vote. Sevier and Clifford, the latter Polk's attorney-general, were appointed commissioners in accordance with the provision of the treaty permitting the exchange of ratifications at the City of Mexico. As their duties were merely the gaining of Mexico's consent to the Senate's amendments, and the hastening of final ratification, their task was light. As soon as it was known that the Senate was modifying the terms of the agreement as signed, the Mexican government ceased all efforts for ratification until the nature of the amendments was known. A few days after the arrival of Sevier and Clifford at Mexico with the amended treaty the Mexican congress agreed to ratification by practically a unanimous vote.

There was no glory in all this for Trist. Polk characterized him as an "impudent and unqualified scoundrel." Upon his arrival at Washington the former chief clerk of the state department found the doors closed to him. He could get the ear of no one, and after vainly trying for some time to collect his salary after the date of his recall, he left Washington. Insisting on having a hearing, he addressed a long communication to the speaker of the House August 7 , I848, accusing the President of high crimes and misdemeanors, including subornation of perjury, and suggesting that he be impeached. ${ }^{45}$ But there was no need for stirring up the matter in the hope of finding political capital against Polk. The time had gone by for that. The letter was received during the last days

${ }^{4}$ Cong. Globe, 30 Cong., I Sess., 1057-58. 
of the session and referred to the committee on foreign affairs, and there it slept. The war was over; Polk's term was drawing to a close; and the country was in the midst of a presidential campaign. Trist was soon forgotten. The result of the election of 18.48 was the choice for president of Taylor, one of the two great Whig generals who had reaped the political popularity that Polk had coveted. Scott was for the time passed by, and nobody had any consideration for the assertive and talkative commissioner who had made the treaty of Guadalupe Hidalgo. But the persistent Trist did not despair, and twenty-two years later he secured from Congress the reward for his successful presumption." The feeble old man, who had been one of Jefferson's family and afterward the friend of Jackson, was at last secure in the belief that he had been vindicated by his government.

${ }^{4}$ Senate Report, 4 I Cong., 2 Sess. 



\section{NDEX}

Aberdeen, Lord, 27; policy of, 31; upon right of visitation and search, $32,33,109$; acquiesces in American expansion, 102; and Texas, 124, 129; and abolition in T'exas, 127; on Texan annexation, 151152; and Texan Diplomatic Act, 172 ; overture on northwestern boundary question, 243; offers line of $49^{\circ}, 262$.

Adams, John Quincy, comment on Tyler and Webster, 27; favors retention of Texas in 1819,59 ; attempts by, to regain Texas, 60; comment upon Butler, 69, 70, 75; comment upon Jackson's attitude toward Texas, 85; and right of petition, 89, 90, 93, 114; address on annexation of Texas, 122; instructions to Rush on northwest boundary, 216; instructions to Gallatin on same, 218; instructions to Middleton and Rush on same, 1823, 226-231; proposition for tripartite agreement on same, $233,237-238$.

Alaman, conference with Butler, 71, 72.

Almonte, Gen. Juan N., minister to the United States, 99; suspends relations with U. S., 188; leaves U. S., 268.

Andrews, S. P., 126.

Annexation of Texas by joint resolution, 162-189.

Armistice between Mexico and Texas, 122.

Armistice between U. S. and Mexico, 317-322.

Aroostook War, 11.

Ashburton, Lady, 40.

Ashburton, Alexander Baring, Lord, $27,39,42,43-57,110$.
Ashburton Treaty, 28-57, 108-110.

Astoria, 204, 206-210.

Atecha, Col. Alexander, 288-294.

Bagot, 210.

Bankhead, 317.

Battle of the Maps, 56 .

Benton, 'T. H., 44, 56, 326; plan for Texan annexation, 184.

Bocanegra, J. M. de, 97; minister at Washington, 98-100; protest against annexation of Texas, 157.

Brougham, Lord, interpellation of, upon Texas, 132.

Buchanan, James, report of, on Maine boundary, 56, 138; secretary of state under Polk, 188; negotiation with Pakenham over Oregon, 250-264; opposition of, to Polk's policy, 253; instructions to Slidell, 274; instructions to Trist, 313.

Butler, Anthony, 68-75.

Butler, Gen. W. O., 324.

Calhoun, John C., 90, 112; and the presidency, 1844, 120; offered state portfolio under Tyler, 138; favorable to Texan annexation, 120; and the tariff, 121; and the attempted annexation of 'Texas by treaty, 138-161; Upshur's successor, 137; secretary of state under Tyler, 141; reverses Nelson's position as to Texas, 144; signs Texas treaty, 148; correspondence with Pakenham over Texas, 150-155; instructions to Green, chargé at Mexico, 156; promise of protection to Texas, 170-171; comment upon the socalled Diplomatic Act, 173-174; position upon Oregon question, 246-249; negotiation with Pakenham over Oregon, 246-249; dropped by Polk, 185. 
"Calhoun conspiracy,"'119-120, 141. California, conquest of, 48, 326.

Canning, George, proposes negotiation over northwest boundary, 239; approves continuation of joint occupation, 241.

Caroline case, 16, 18, 23-25, 55.

Cass, Lewis, on the McLeod case, 19; on the Quintuple Treaty, 33-37, 109.

Castillo y Lanzas, 76.

Castlereagh and Rush, and the northwest boundary, $211,217$.

Childress, George C., 77, 78.

Churubusco, 319.

Claims against Mexico, 76, 107.

Clay, Henry, 22; instructions to Poinsett, 61-64; letter upon Texas, 158.

Clifford, Nathan, 328.

Conventional line for northeast boundary, 14, 45-46.

Corn laws, repeal of, 263.

Creole case, 47-49, 55.

Davis, Governor, 43.

Donelson, A. J., chargé to Texas, 178, 180-182, 186-188.

Doyle, Percy, activity of, on behalf of Texas, 122.

Edwards, Ninian, 60.

Elliott, 122-123; reports to Houston, 147; arranges armistice, 186-187.

Ellis, Powhatan, 75-79, 86, 87, 94-97.

Escurial, convention of the, 211-216.

Everett, Edward, 33, 39, 48, 102, 109, 111; reports upon Aberdeen's policy, 132.

Expansion sentiment, 58.

Extradition, 55.

Fairfield, Governor, 41, 42.

Florida treaty, $59,60,63,64,70,73$, 225.

Forsyth, John, 10, 12, 13, 73, 78, 83, $84,86,95$.

Forty-ninth parallel, history of, 193196.

Fox, H. S., 12, 23-26, 38.
France and Texan diplomatic act, 172.

Gaines, Gen. E. P., 79.

Gallatin, Albert, 9; negotiation of 1818 , 218-223; negotiation of 1826-7, 239-241.

Ghent, negotiations at, 201-206.

Gillespie, Lieut. A. H., 278-281.

Gilmer, Thomas W., letter of, 119, 120; appeal of to Calhoun, 139.

Gorostiza, M. E. de, 79, 80, 86.

Goulburn, 218-223.

Gray, Captain Robert, 204.

Great Britain and Texas, 122; and abolition, 133.

Green, Benj. E., 156.

Green, Duff, 112; in England, 124-125; report to Upshur, 129; consul at Galveston, 179, 183.

Greville's Journals, quoted, 41 .

Grey, Lord, 28-29.

Guadalupe Hidalgo, treaty of, 309329 ; signed, 327 ; terms of, 326; ratified, 328.

Guizot, 34-37.

Hamilton, Robert, 77, 78.

Ifarrison, W. H. H., 22, 25.

Hawkesbury, Lord, 5.

Harrowby, Lord, 197, 198.

Henderson, Gen. J. P., 81, 82; at Washington, 137, 145.

Herrera, 189, 284.

Hernandez, 74.

Houston, Sam, 87; attitude toward Great Britain, 115-119; overture to U. S., 116; letter to Jackson, 121; declines Upshur's overture, 135; change in policy of, 136; requests protection from Murphy, 136; double policy, 146; upon annexation, 160; policy after rejection of treaty, 160; enmity toward Jones, 167; and Diplomatic Act, 175; final message, 181.

Howard, Tilghman A., 165, 178.

Hunt, Memucan, 81-87.

Ingersoll, Charles J., 138. 
Jackson, Andrew, 10; declines appointment as minister to Mexico, 60 ; policy toward Mexico in 1829 , 64; instructions to Poinsett, 67; and Butler, 70-75; and Texan revolution, 76-79; and Texan annexation, 80-82, 92, 93; and claims against Mexico, 84-86; and Florida treaty, 89.

Jay, William, 90.

Jay's treaty, 4.

Jefferson, Thomas, 4.

Joint-cruising agreement, 53, 54, 109. Joint occupation of Oregon proposed, 221 ; convention of $1818,218-223$; convention of 1827, 239-242.

Jones, Anson, 84, 146; agrees to armistice, 123; attitude toward Houston, 167, 175-177; policy as president of Texas, 186.

Jones, Commodore Thomas Ap C., 93, 99, 103-105.

Kendall, George M., 94.

King, Rufus, 4, 5.

King-Hawkesbury negotiation, 192, 193.

La Branche, Alcée, 79.

Lamar, Mirabcau B., 83, 87, 93, 94, 114.

Larkin, Thomas O., 105, 278-281.

Legaré, Hugh S., 111.

Livingston, Edward, 71, 72.

Livingston, Robert R., 5.

Louisiana Treaty and northwest boundary, 193.

McDuffie, George, 142, 153.

Mackenzie, Commander A. S., 298308.

Mackintosh, 317, 319.

McLcod case, 16, 19, 22-27, 38.

Madawaska settlements, 49.

Madison, James, 15.

Manifest destiny, 58.

Martinez, 86.

Maxcy, Virgil, 140, 143.

Melbourne, Lord, 28, 29.

Mexican War, 58. 288-329.
Mexico and Texan annexation, 156.

Mexico, relations with, 58-88.

Mexico, City of, occupied by Scott, 322.

Middleton, negotiations of, at St. Petersburg, 226-237.

Mitchell's map, 9.

Monroe, James, 6, 59, 60, 61; negotiation of, 198-200.

Monroe Doctrine, 61, 224-238.

Monterey, capture of, 93, 103-107.

Morfit, Henry M., 78.

Murphy, W. S., 116; and Houston, 123; urges annexation, 131-132; promises protection to Texas, 136; rejected by the Senate, 159 .

Nelson, John, 143.

Nesselrode, Count, 235.

Netherlands, King of the, 9.

Nootka Sound treaty, 211-216.

Northeastern boundary controversy, 1-16, 38, 41-47, 49-53, 56.

Northwcstern boundary, under treaty of 1783,$192 ; 1803-1818,190-223$; 1818-1846, 224-242; 1846, 243-264.

Nueces Rives, 67, 320.

Oregon question, 102, 110, 190-223; 224-242; 243-264.

Oregon treaty, 243-264; signed and ratified, 263.

Pakenham, Richard, and Texas, 150155, 245; and Oregon, 246-249; and Buchanan, 252, 257.

Palmerston, Lord, 12, 15, 17, 26, 28$30,36,38,39$.

Paredes, 284.

Parrott, W. S., 107; mission to Mexico, 269-271.

Peel, Sir Robert, 27, 28, 36, 40; and Oregon, 263.

Petition, right of, 59, 89.

Pillow, Gen. G. J., 318.

Pinkney, William, negotiation of, 198-200.

Poinsett, Joel R., 61-70. 
Polk, James K., 58, 159; election of, 176-177; and Oregon, 249-264; withdraws offer of $49^{\circ}, 252-254$; policy toward England, 254-257; message of 1845,258 ; refuses to arbitrate, 259; seeks consent of Senate in Oregon matter, 259, 261; sources for history of administration of, 265; programme as President, 267; plans war against Mexico, 294-298; and Santa Anna, 298-308; overtures to Mexico, 309; plan for conquering peace, 310 .

Presidential campaign of $1844,157$.

Princeton disaster, 137, 140, 141.

Quintuple treaty, 30, 31, 39, 109.

Reily, James, 117.

Rio del Norte, $61,63,67,80,94,321$, 326.

Rives, resolution of, upon annexation, 166.

Rouse's Point, 46.

Rush, Richard, negotiation of, 224235; conversations with Castlereagh, 211, 217.

Russian ukase of 1821, 224-225.

Russo-American treaty of 1824, 236.

Russo-British treaty of 1824, 238.

Saligny, 186, 187.

Santa Anna, 72-74, 80, 81, 99, 122; overthrown, 184; probable successor of Paredes, 286-287; granted permission to reënter Mexico, 298; and Trist, 317-322; abdication of, 322.

Santa Fé expedition, 93-95, 118.

Scott, Gen. Winfield S., 311.

Sevier, Ambrose P., 328.

Seward, William H., 25.

Shannon, Wilson, 169, 170; methods in Mexico, 182; leaves post, 268.

Slave-trade, 20-22, 30, 35, 36, 53.

Slidell, John, mission of, 271-277; 281-286.

Smith, Ashbel, 126.

Sniveley's expedition, 118.

Spain's claim to northwest coast in 1807, 200.

Sparks, Jared, 43.
Stevenson, Andrew, 19-22, 28, 31.

Taylor, Gen. Zachary, 297.

Texas, annexation of, 58,60 ; made a sectional question under Calhoun, 137; negotiation for, begun by Tyler, 139; by joint resolution, 162-189.

Texas, commercial treaty with, 70 , $87,88$.

Texas, negotiations with Mexico concerning, 58-88; negotiations for, under Upshur, 114-137; under Calhoun, 138-186.

Thompson, Waddy, 87, 100, 106, 107. Thornton, Edward, 317, 323.

Treaty of annexation with Texas, 114161 ; doubt as to ratification, 146; terms of, 148, 150; vote upon, 158 , 159.

Treaty of $1819,59,60,63,64,70,73$. Treaty of $1827,9,237-242$.

Treaty of 1846, 243-264.

Treaty of Guadalupe Hidalgo, 309329.

Treaty of Ghent, 6-9, 12.

Treaty of peace with England, 1, 52.

Treaty of Utrecht, 6, 194-196.

Treaty, commercial, with Texas, 70 , 87,88 ; rejected, 118.

Treaty of Washington, 28-47.

Trist, N. P., consul at Havana, 31, 311-329; mission to Mexico, 313; instructions to, 313; quarrel with Scott, 314-317; and Santa Anna, 317-322; recalled, 323; negotiates treaty of Guadalupe Hidalgo, 324326 ; payment to, 329 .

Tyler, John, 25, 27, 33-38, 44, 47, $54,57,58,60,90-93,100,162$, 111, 112; presses annexation, 114, 116; reasons for delay, 118; offers state portfolio to Calhoun, 138; attitude toward Calhoun, 142; sends Texas treaty to Senate, $155,156,161$; mesșage favoring annexation by joint resolution, 160-161; nomination for the Presidency, 162; message to House upon Texas, 164; promise 
of protection to Texas, 169; adopts House plan, 185; and Oregon, 243-244.

Unshur, A. P., 93, 112; becomes secretary of state, 124; instructions to Murphy, 131; proposes annexation, 134; attitude toward Murphy, 134; relations with the Senate, 135; and Oregon, 244; killed, 137.

Utrecht, treaty of, 6, 194-196.

Van Buren, Martin, 11, 64-57, 82, 85, 89; presidential candidate in 1844 , 120; letter upon annexation, 158.

Van Zandt, Isaac, 119; requests protection from Upshur, 136; and Henderson, 144.

Visitation and search, right of, 17, 30-32.

Von Holst's Constitutional History, $65,84,85,90$.

Walker, R. J., 163.

Walpole, Sir Spencer, quoted, 29.
Webster, Daniel, criticism on Van Buren, 12; plan for conventional boundary, 13-15; becomes secretary of state, 22; and McLeod and Caroline cases, 24-27, 38, 55-56; and the slave-trade, 33; and Cass, 37,109 ; overture for a conventional line, 40-42; negotiation with Ashburton, 42-56; and the Creole case, 47-49, 55; and Texas, 91, 92; and Santa Fé prisoners, 94, 95; and claims against Mexico, 96, 97; attitude toward Mexico, 97-100; and California, 100-102, 110; and the Monterey incident, 106.

Wheaton, Henry, 36 .

Wilkins, 138.

Williams, Reuel, 41, 42.

Wilmot Proviso, 90.

Wise, minister to France, 111, 172.

Woll, General, 168.

Wright, Silas, 311. 






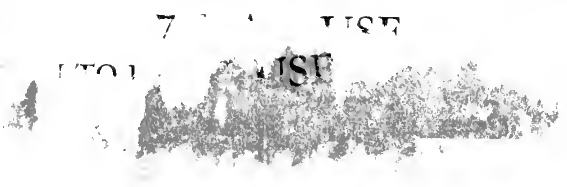


GENERAL LIBRARY - U.C. BERK | ||||||||||||||||||||||||||||||||||||||||-||| 


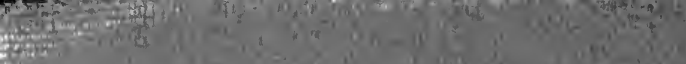

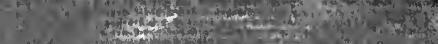

$+1$

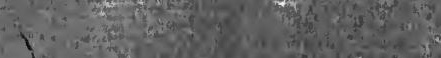

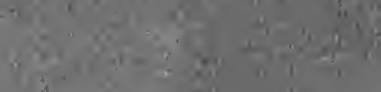

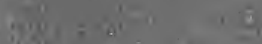

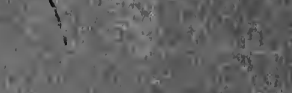

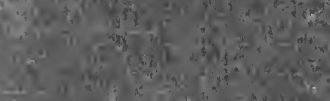

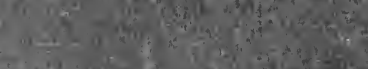

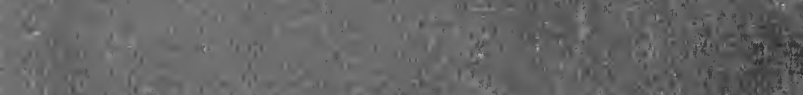

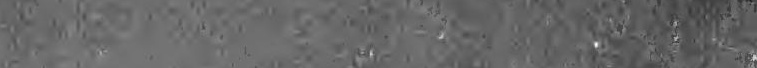

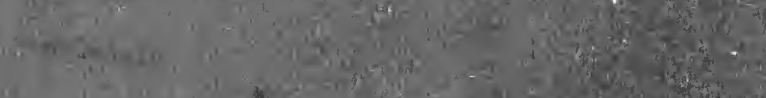

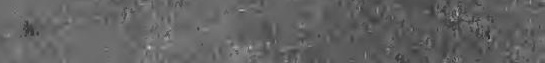

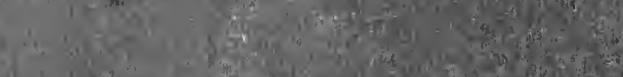

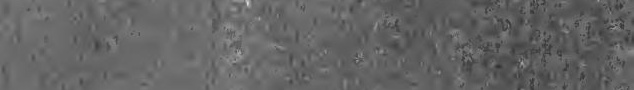

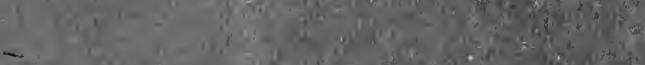
-

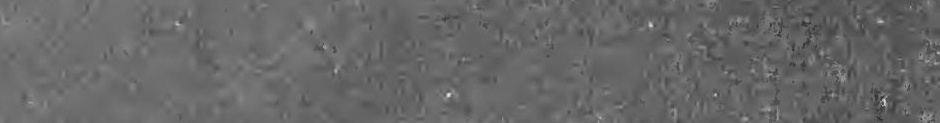

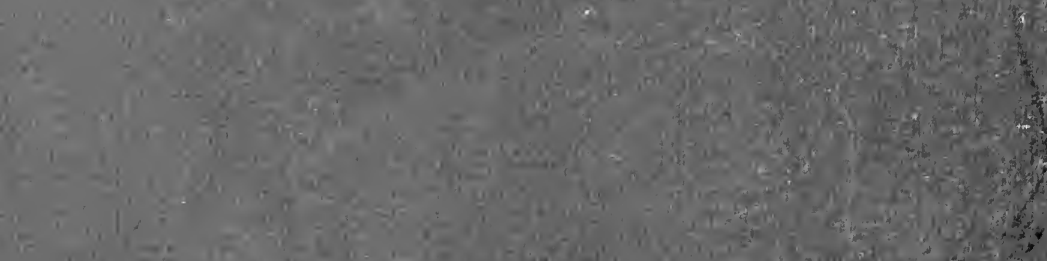

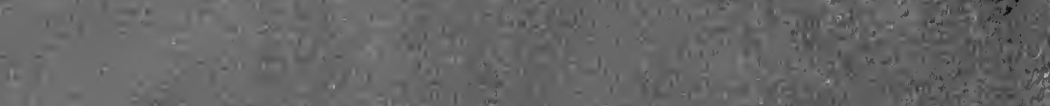

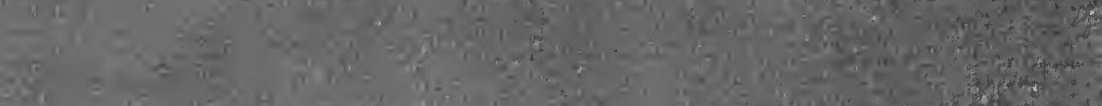

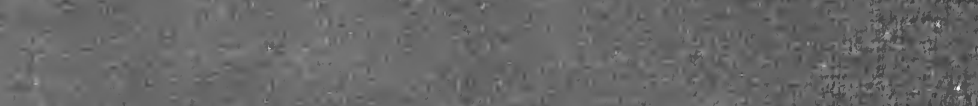

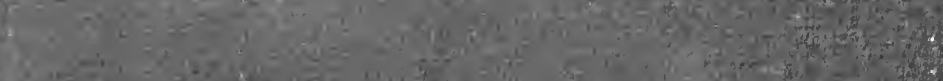
4.7.

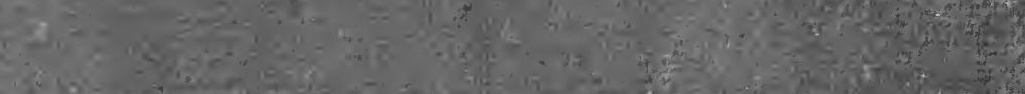

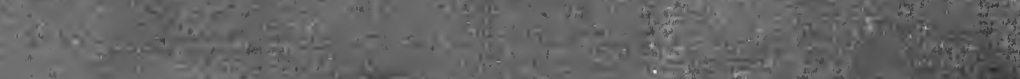

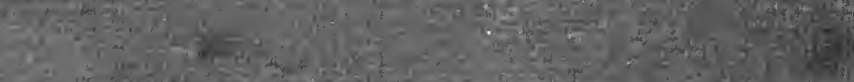
Wh

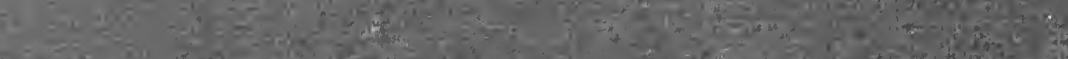

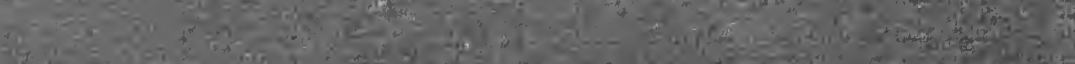

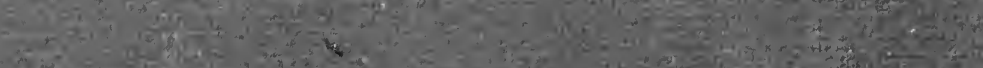
de

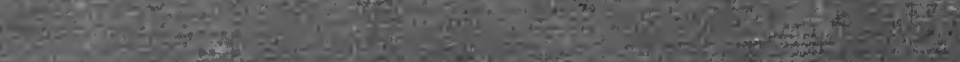
Wif $\sqrt{2} i^{2}$

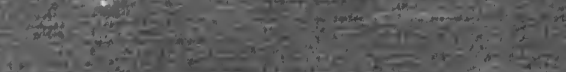

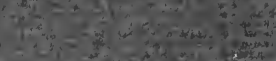

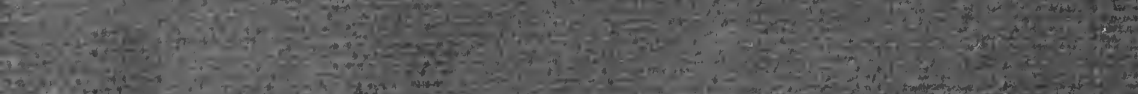
200 C. a

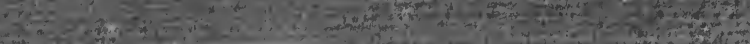

